\title{
Dissident Diaspora: Genres of Maroon Witness in Anglophone and Francophone Caribbean Literature
}

\author{
by \\ Sarah Gabriella Waisvisz
}

A thesis submitted to the Faculty of Graduate and Postdoctoral Affairs in partial fulfillment of the requirements for the degree of

Doctor of Philosophy

in

English Language and Literature

Carleton University

Ottawa, Ontario

C 2014, Sarah Gabriella Waisvisz 


\begin{abstract}
This study brings human rights criticism into conversation with postcolonial and transnational studies in order to contribute to a decolonizing of trauma theory. I demonstrate how generically innovative writers from the Caribbean diaspora invoke the tradition of the fugitive slave or maroon, and in so doing, put forward revolutionary ideas about identity, race, and belonging. The genre-bending literature examined in the dissertation is engaged in a form of dissident literary maroonage. Overall, the texts demonstrate a dual focus on ethics and genre as they confront the vexed representation of human rights issues, past and present. I argue that a human rights-oriented approach to Caribbean literature, in tandem with critical attention to form and genre, can attend to witness testimonies, memory, and representations of suffering in literary texts, and can, consequently, draw attention to an ethically-charged poetics of diaspora.

The Francophone and Anglophone texts examined in the dissertation, by M. NourbeSe Philip, Dionne Brand, Gisèle Pineau, Myriam Chancy, Edwidge Danticat, Jan J. Dominique, and Saidiya Hartman, represent the paradoxes and tensions of human rights issues within a Caribbean context: they engage productively with loss and mourning; underscore the ambivalent impact of ethnic, cultural, and racial mixing; narrate survivor as well as perpetrator testimony; and contribute to alternative memory projects informed by an interrogation of belonging/un-belonging. I argue that the deployment of the maroon trope in these texts indicates an effort to "Caribbeanize" issues related to human rights; consequently, I introduce the concept of maroon witnessing to help bridge the gap between critical approaches to postcolonial studies and typically western-biased human rights scholarship and trauma studies. Ultimately, the diasporic writers discussed in this project emerge as witnesses and activists who, from their position "lòt bò dlo," across the waters, confront the limits of genre and contribute to a dissenting, defiant re-articulation of Caribbean poetics.
\end{abstract}




\section{Acknowledgements}

It takes a village.

First, I would like to thank my Thesis Director Sarah Phillips Casteel, for her unfailing support, encouragement, and invaluable mentorship. I must confess that I have enjoyed our process, and I know that I could not have done it without you. Please accept my thanks, with much gratitude, especially for encouraging me to "just write faster!"

Second, I would like to thank the members of my committee. Brenda Vellino introduced me to human rights literature and theory as a scholarly pursuit and re-opened my eyes to poetry; Christine Duff first helped me to read Césaire and Glissant; and Sukeshi Kamra, Chris Bongie, and Catherine Khordoc provided invaluable insight and critique.

I would like to acknowledge the support of the Department of English at Carleton University. I am grateful to the Graduate Chairs who supervised my time in the program-Grant Williams, Brian Johnson, and especially Barbara Leckie, who always had a moment to talk. I would like to thank my thesis siblings Devika Wasson, Chris Vanderwees, Emma Peacocke, David Mastey, Gabrielle Etcheverry, Aliesha Hosein, and Steve McLeod: I am glad we were all brothers in arms. I owe a debt of gratitude to Lana Keon, Jennifer Warren, and Judy Katz, who over the years made sure I did not accidentally sabotage my degree. Many thanks are due to Franny Nudelman, Jodie Medd, Julie Murray, and Jennifer Henderson for their mentorship, as well as to the members of the "Postcolonial' Research and Working Group" and the Centre for Transnational Cultural Analysis (CTCA). My doctoral studies have been funded by the generous support of the Social Sciences and Humanities Research Council of Canada (SSHRC), the Ontario Graduate Scholarship program (OGS), and at Carleton, the Department of English, the Faculty of Graduate and Post-Doctoral Affairs, and the Natalie Luckyj Scholarship Fund.

I have been fortunate to also find support outside of my home department. I would like to give special thanks to Alexandra Schultheis Moore, Elizabeth Swanson Goldberg, Greg Mullins, and the members of the ACLA Human Rights and Literature seminars over the years: your vibrant scholarship has helped me to find my intellectual moorings. My thanks to all of you.

I am thankful for the generosity of the friends and strangers I met on my own diasporic, nomadic, maroon wanderings; this dissertation was researched and written in more locations than I can count, and I am grateful for the help I had along the way. For keeping me laughing, even while crying: Christine Armstrong, Connie Crompton, Tamara Fathi, Jacynthe Fugère-Bourdages, Lesley Hoyles, Emily Pearlman, and Bronwyn Steinberg. To Megan MacDonald and Jerilyn Sambrooke: Megan was right: it is a marathon! For giving me a soft place to land in Ottawa and in Berkeley, I owe much to Monique Andrews and Tamara MacIntyre for their unparalleled generosity during a challenging time. Thank you to Camille Rudney and Roxanna Vahed, my intrepid interlocutors and companions in belonging / un-belonging.

I would like to thank my Gold Crescent family and my OrH family for standing in for those far away. I offer gratitude to my parents and to those in my family whose stories have inspired this book. The last note is to my brother: David, I did university for both of us, which is why it took so long. And through it all I have learned one thing: remembrance will be our sole inheritance. 


\section{Dedication}

In her small village of le François in Martinique, my great grandmother was famous for encouraging her children and the village children to pursue their studies. Even though she herself was illiterate like most slaves and those who grew up on the plantations, she would help the younger generation to revise their lessons. She admonished their laziness and celebrated their successes, and she could often be seen holding a book. She was a proud and formidable woman. If an insolent young person, who was tired of her nagging, mocked her for holding a book upside down, she would say with confidence: "Quand on sait lire, on lit dans tous les sens: If we know how to read, we read in all directions."

This book is dedicated to the memory of my courageous ancestors. 


\section{Table of Contents}

Abstract

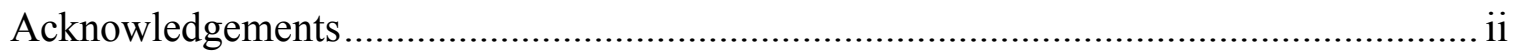

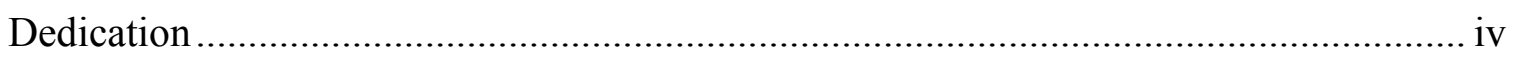

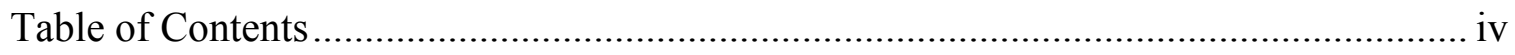

Introduction:

Chapter 1: Performative Diasporic Mourning and Maroon Witness in the Caribbean Long Poem: M. NourbeSe Philip's ZONG! and Dionne Brand's Inventory ............................. 36

Chapter 2: Vodou Novels as Alternatives to the Postcolonial Gothic in Chair piment by Gisèle Pineau and The Loneliness of Angels by Myriam Chancy ................................. 89

Chapter 3: The Maroon Bildungsroman and the Work of Dangerous Memory in Edwidge Danticat's The Dew Breaker and Jan J. Dominique's Mémoire d'une amnésique ......... 146 Chapter 4: "Where the stateless might thrive": Queer Diasporic Un-Belonging and the Maroon Memoir in Dionne Brand's A Map to the Door of No Return and Saidiya Hartman's Lose Your Mother .......................................................................................... 197

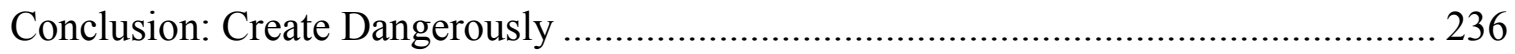

Epilogue: Notes From a Return to the Native Land ............................................... 243

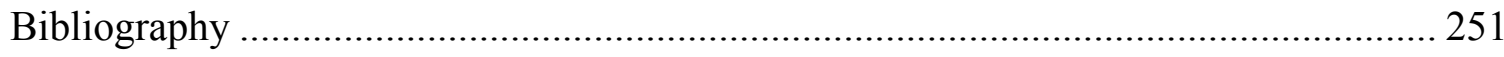




\section{Introduction}

And when we speak we are afraid / our words will not be heard / nor welcomed / but when we are silent / we are still afraid / so it is better to speak / remembering / we were never meant to survive.

Audre Lorde, "A Litany For Survival”

This dissertation participates in the emergent scholarly project of bringing human rights-oriented literary criticism into conversation with postcolonial studies in order to encourage a decolonization of trauma studies. In the chapters that follow, I demonstrate how genre-bending literature from diasporic women writers contributes to an understanding of contemporary Caribbean literature that is both locally and transnationally situated. The archive I address contends with the long legacy of colonization, slavery, and indenture, as well as the paradoxes and tensions of human rights issues within a Caribbean context. The literary texts narrate survivor as well as perpetrator testimony and postmemory; present alternative memory projects; underscore ethnic, cultural, and racial mixing; and foreground the complex transitional justice negotiations necessary in post-traumatic and post-conflict societies in which survivors and perpetrators live together. Most especially, the texts engage in a retroactive reckoning and memorialization process with the trauma of slavery. The writers examined here are a voice of testimony for the Caribbean region and the diaspora, and they contribute to a decolonization project that has a broad agenda and a potentially planetary reach. When Caribbean artists write in order to preserve, expose, or disseminate their stories or others' stories, their often risky work about un-redressed human rights atrocities past and present can put them in danger. I argue that a human rights-oriented approach, in tandem with critical attention to form and genre, attends to witness testimonies and representations of 
suffering and resilience in literary texts, thereby underscoring the role of the artist and the public intellectual.

My exploration of the role of human rights testimony from a globalized Caribbean contributes to the fields of diasporic, postcolonial, and transnational literature and criticism. In the dissertation, I develop the concept of a diasporic maroon poetics as well as the figure of the maroon witness; both represent a critical position of distanced and dissident witnessing that does not depend on geographical location but on the historical experience of diaspora, so that a contemporary Caribbean "diasporic maroon witness" might live in the Caribbean or outside its cartographical limits. The critical, activist stance of the maroon witness extends a Caribbean literary tradition of displacement and dissent with its roots in the history of indigenous and slave resistance. Because the historical experience of maroonage ${ }^{1}$ implicated indigenous communities as well as slave populations originally from Africa, and in fact depended on their interaction, I read the tradition of maroonage as simultaneously indigenous, in other words native to a place, and diasporic. Subsequently, the strategic deployment of the maroon trope in Caribbean literature is a gesture that is both locally situated and transnational at once.

In the post-slavery / post-emancipation era, literary rather than actual maroonage is the chosen arena of revolt and dissidence for many Caribbean writers. The Anglophone and Francophone literary texts that I explore are generically and formally innovative and in different ways they each engage in literary maroonage in their pursuit of cultural dissent and "generic resistance" (Castle 4). I argue that the deployment of the maroon trope in these texts indicates a commitment to "Caribbeanize" issues related to human rights; consequently, we can look to the concept of maroonage to help bridge the gap 
between critical approaches to postcolonial studies and typically western-biased human rights scholarship and trauma studies. The maroon--as a fugitive and resistor to the crime of slavery--is a powerful localized figure for standing up to injustice, imagining a different future, and building new communities. Ultimately, the writers discussed in this project contribute to a necessary, albeit as yet non-existent, artistic truth and reconciliation project for the crime of slavery: this cultural redress project is dreamed of, in part, by artists living outside of the Caribbean, "lòt bò dlo," in diaspora, across the waters.

\section{Diasporic Distance}

In Tout bouge autour de moi (2011), a collection of snapshots, essays, and recollections, Dany Laferrière recounts his experience of the earthquake that rocked Haiti on January 12, 2010 while also articulating the tensions he feels as a diasporic subject. Caught in Port-au-Prince on January 12th, Laferrière witnessed first-hand the magnitude of destruction, the collapse of Haiti's infrastructure, and the countless corpses. He also fled the wreckage as soon as he could, and the international media attacked him for doing so. Yet as he writes in Tout bouge autour de moi, Laferrière felt that his testimony as a witness would be more effective from outside the island, away from the catastrophe: "I had to distance myself in order to preserve these images, these images that still burn within me" (126). ${ }^{3}$ Laferrière's stubborn response to his critics reflects his sense of duty to be a witness to what he had seen; as he understood it, his role was to be a mediator and liaison between Haiti and the "West." Tout bouge autour de moi, written almost exclusively in European hotel rooms and train compartments, is a fragmented text that 
continually vacillates between the genres of essay, testimony, memoir, and reportage. It is a text about the experience of diasporic maroon witnessing: about the privilege of escape and the guilt of survival, about the duty to testify, about the urge to travel, and about the rootlessness and ambivalence felt by the diasporic subject.

The Laferrière example emblematizes the concerns of my project, which addresses the complex poetics and experiences of the figure of the diasporic maroon witness. Looking in particular at texts by women writers from the Anglophone and Francophone Caribbean tradition who belong to the wide net of the African diaspora, I am interested in how characters and writers view and articulate relationships to current homes, distant homelands, and the movement in between. ${ }^{4}$ In the Caribbean context, the term diaspora suggests multiple origins: in colonialism, the slave trade, and indentured labour, which led to the African and Indian diasporas; in the diasporic experiences of immigrants to the Caribbean and their descendants, resulting in ties to diasporic communities in China, Syria, Europe, et cetera; and in the experience of being a Caribbean abroad, which leads to often doubled and tripled experiences of diaspora, such as the complex affiliations held by a Haitian-Canadian living in Paris. No matter his or her reason for flight, and whether or not that departure happened in the far past or in the present, the diasporic subject often lives and travels between several countries, and thus he or she responds to various nations and cultures in his or her artistic work. The example of Laferrière highlights the positive outcome that distance can bring; separation from Haiti and the earthquake allowed the author to see more clearly and to testify effectively, at least for the purpose of his book. I argue that the diasporic maroon witness sees with a clear, wide lens that captures multiple physical and temporal sites. The inherent distance 
and ambivalence felt by the diasporic maroon witness can thus lead to new insight into the importance of a witnessing and redress process, especially in the case of Caribbean societies in transition to democracy and social justice after a history of colonization, military rule, or dictatorship.

Post-structuralist theorists including Paul Patton and Rosi Braidotti have forged links with postcolonial theory in order to think about diaspora in relation to the concepts of "nomad thought," "nomadology," and a privileged "nomad subjectivity," as articulated by Gilles Deleuze and Félix Guattari. ${ }^{5}$ Julie Wuthnow argues that Deleuze and Guattari's theories about nomadology are ultimately "counterproductive" for post-colonial scholarship because they can lead to a "politics of disappearance" of indigenous knowledge systems, thus only contributing negatively to post-colonial and decolonizing scholarship (184). As Wuthnow explains, if the constant movement and travel of the transient nomad are privileged at all cost, then ancient, locally-rooted Indigenous cultures and life-ways necessarily become undermined and invalidated, thus making European knowledge normal and hegemonic. How can Indigenous politics and notions of diasporic subjectivity be reconciled or brought into conversation? Does one have to undermine the other? ${ }^{6}$ I want to suggest here that attention to Caribbean traditions such as vodou and the figure of the maroon can offer models and practices that are both local and diasporic, both indigenous and syncretic, and that they therefore offer potentially useful valences for diasporic subjectivity. Notwithstanding the complexity inherent in discussions of indigeneity within the Caribbean context, I will expand my discussion of vodou as a simultaneously indigenous and diasporic framework due to its development out of the relation between Indigenous Caribbean and diasporic African spiritualties. Moreover, the 
phenomenon of creolization and the "soup of signs" that defines the Caribbean (Benítez-

Rojo 2)--the direct result of conquest and colonialism--complicates paradigms about who is Indigenous, settler, or immigrant and who can claim "legitimacy" as a Caribbean subject. Instead of drawing hard lines, I am more interested in the ambiguities and paradoxes that the Caribbean presents and how that very opacity, rendered in Glissant's words as opacité, might offer a constructive approach for the globalized world of the twenty-first century.

\section{Historical and Literary Maroonage}

The distance and critical attitude of the maroon witness responds to a long tradition of dissent in the Caribbean with roots in the history of indigenous and slave resistance and in the historical figure of the maroon. The experience of maroonage in the Caribbean context refers to the tradition of slaves who resisted their masters, ran away from the plantations, and founded free communities or maroonages in forests and mountains, often joining up with equally imperiled Indigenous communities. ${ }^{7}$ From there, they built maroon societies distinct from plantation societies and developed acts of defiance and resistance; dreams of liberty and freedom were often informed by the myth of crossing the waters to return to Africa. The myth of the maroon thus invokes the notable Caribbean landscapes of forested mountains, plains, and of course the sea. Significantly, Glissant writes of this physical landscape as a microcosm for the Caribbean region that replicates the physical geography of the continent of South America. ${ }^{8}$ Moreover, Chris Bongie's use of Edward Kamau Brathwaite's phrase "islands and exiles" as the title to his book about creolization and post/colonial literature signals a relation 
between geography and emplacement/ estrangement in the Caribbean context. ${ }^{9}$

As represented in Anglophone, Francophone, Dutch, and Hispanic literature of the Caribbean region, the figure of the maroon or le marron noire is as significant a figure as le conteur, the community storyteller. Especially since Haiti's 1804 birth as the first Black Republic, the figure of the revolutionary maroon of an African-resistor has played an iconic role in the culture of the Caribbean. ${ }^{10}$ Cynthia James explains that "the main symbol of maroon theory is the maroon as venerated hero, warrior, and ancestral figure" (8). James highlights Brathwaite's notion of a common "submerged / maroon ancestral heritage" that, in literature and critical theory related to the Caribbean, becomes a trope related to survival (8). For Brathwaite, maroonage involves "resilience, survival, resourcefulness, and innovation" as well as "ancestral guidance and tragic warriorhood" (8). Someone who is a maroon is therefore associated with rebellion, resistance, threat, flight, escape, and hard-earned freedom.

Maroonage is not simply an act of resistance in the historical sense of flight and revolt, however. I read maroonage as an action of dissent that, emerging from the legacy of slavery in its contemporary form, pursues a kind of cultural decolonization. Haitian critic and writer René Depestre conceives of cultural maroonage as "an artistic mission of resistance--in postcolonial terms, artistic effort that stakes its distinction on writing against the grain of the European tradition and European depiction of the Caribbean" (Depestre 20 qtd. in James 9). Interestingly, "the tendency today is for Haitian writers to perform 'revolutions' in their own literary work, often through the pervasive use of formal innovations" (Douglas 59). ${ }^{11}$ I extend the concept of literary revolutions to the Caribbean as a whole, where cultural and literary maroonage is the chosen arena of revolt and 
dissidence for many artists, both in the region and in the diaspora. ${ }^{12}$

Following from Depestre, what characterizes representations of the contemporary maroon figure and the work of Caribbean writers and artists who produce art in exile or in diaspora? How is their position of critical distance similar to and different from that of the traditional maroon? This dissertation posits that there is something dissident and potentially dangerous about the witnessing from a distance that diasporic subjects perform, and that with the co-mingling of dissidence and distance (or éloignement, estrangement), comes a particular critical stance. Within the realm of littérature engagée, diasporic writing, and conversations in trauma theory about witnessing, the diasporic maroon witness embodies the distance and defiance of the traditional Caribbean maroon figure who resisted oppression on the slave plantations. The conjunction of the two conditions of distance and dissidence is necessary for a contemporary figure to be a maroon witness. For artists, writers, journalists, and other producers of culture and art who are in diaspora - whether in self-chosen, mandated, or internal exile from their home society or heirs to other diasporas such as the African diaspora - their work is critical and possibly dangerous.

The revolutionary history of Haiti continues to inspire the people and cultures of the Caribbean as well as colonized and oppressed people elsewhere. While Rachel Douglas notes a lack of engagement with the Haitian Revolution and its revolutionaries for contemporary Haitian writers, she writes of the "fascination" with this event elsewhere in the Caribbean, especially in Martinique and Guadeloupe (58). Haiti's declaration of independence, after thirteen years of concerted revolt and agitation as well as spiritual engagement by Haitian Vodou practitioners, ${ }^{13}$ forever marks the country as 
simultaneously inspiring and reprehensible, depending on the observer. This dissertation purposefully looks to Haiti's rich and complex literary and cultural traditions in part to honour its maroon-inspired victory over colonialism. It is not an accident that my project takes up the work of several Haitian writers, including Myriam Chancy, Edwidge Danticat, and Jan J. Dominique, and gestures to texts by Laferrière, Depestre, Frankétienne, and others. In parallel to an extraordinary cultural output, and in typical paradoxical fashion, the independence of Haiti also unleashed the conditions for abject poverty--worsened by political blockades and reparations inflected by Europe--as well as political instability, dictatorial regimes, military invasion, et cetera. Thus, any discussion of Haiti's epic history must not gloss over or ignore the price the country has paid for its independence; accordingly, the books by Haitian writers that are examined here contend with examples of contemporary violence that have roots in historical traumas.

At the same time, this dissertation also relies heavily on the intellectual and scholarly contributions of Martinican writers Aimé Césaire, Frantz Fanon, and Édouard Glissant who promoted the importance of a distinctly Martinican and Antillean approach to literature, cultural identity, and politics, thereby engaging in their own literary-maroon revolutions. Although their writing about negritude and anti-colonialism helped to inspire independence movements in the Caribbean and Africa, Martinique remains to this day a neo-colony, officially an overseas department or DOM, of France. ${ }^{14}$ The examples of Haiti and Martinique underscore the ambivalence and complexity at work in Caribbean culture and literature. Haiti and Martinique are in some ways two symbolic sides to a coin, and my use of literary and critical examples from these islands demonstrates my interest in taking a comparative Caribbean approach while nevertheless remaining 
conscious of island-specific intellectual, linguistic, and material histories.

Building from the material contexts that made escaping slavery necessary, maroonage as an analytical and formal strategy opens up different angles for discussing literary representations of resistance, decolonization, mixed-race politics, diaspora, creolization, loss, subjectivity, and critique. Importantly, maroonage's relation to escaping confines and limits relates productively to authorial escape and acts of formal innovation and generic experimentation. Overall, this dissertation's interest in the relationship between maroonage and generic innovation productively re-orients diasporic Caribbean literary criticism towards resilience and reveals the historical and present examples of cultural limitations that still inspire the need for escape.

\section{Human Rights, Trauma, Testimony, and Postcolonial Literary Criticism}

Literary studies have a long and tangled history of engagement with human rights concerns. In Theoretical Perspectives On Human Rights and Literature, Elizabeth Swanson Goldberg and Alexandra Schultheis Moore provide an overview of the development of what they consider the "emergent" "interdiscipline" of Human Rights and Literature (1). The authors argue that the development of this interdiscipline is founded in the critical movements and approaches of trauma, postcolonial, holocaust, genocide, and feminist studies, as well as 'the rise of the 'personal story' in responding to social suffering" (2). Additionally, the 1970s saw human rights discourses and ideals become mainstream in part due to the popularization of Amnesty International and their human rights campaigns; this period also saw the emergence in North America of the "law and literature" scholarly movement as well as the "ethical turn" in literary and 
cultural theory. Since September 11, 2001, in the United States especially, the academic field of human rights and literature has "gained formal momentum" (2). Although defining an interdiscipline is challenging, Goldberg and Moore encourage a "dual focus upon form and content" in order to "posit a human rights-oriented literary criticism that $[\ldots]$ attends to what is shared by narratives of suffering while at the same time recognizing the particular situations and positions of those who suffer" (4). My focus on ethics and genre in this dissertation is aligned with Goldberg's and Moore's ambitious attention to the inherent paradoxes that occur when literary studies intersects with the field of human rights. Like them, I too am concerned with the qualities of form as well as narrative content, with how "narratives probe the limits of language, representation, and translation to depict their subjects adequately," and I pursue a commitment to criticism that recognizes "the arguably 'west-centric' history of human rights" (4) and intends towards ethics, empathy, and social justice.

As Joseph Slaughter demonstrates with his work on the Bildungsroman genre, and as Kay Schaffer and Sidonie Smith discuss in relation to the testimonial, autobiography, and memoir genres, the articulation of the Western neo-liberal subject informs both the kind of narrative subject written into Western literature as well as the understanding of what it means to be human as entrenched in such documents as the 1948 Universal Declaration of Human Rights. Lynn Hunt argues that what we consider to be modern human rights were first discussed and articulated during the American and French Revolutions because of the empathy-fostering affect of novels, especially epistolary novels, on the European reading public. ${ }^{15}$ James Dawes writes that "human rights work is, at its heart, a matter of storytelling" ("Literary Study" 394), and Slaughter underscores 
how "personal stories are the contemporary currency of human rights projects, and it seems difficult now [...] to imagine the genre as new in 1961 or to imagine a time before personal stories and human rights campaigns" ("Foreword" xiii). In other words, the Western neo-liberal world determined who had, who has, and who deserves human rights, according to the literature and philosophy that developed out of the European Enlightenment and the timely emergent systems of industrialization and global capitalism that institutionalized colonialism and slavery. Thus, there is a dialectical relationship at work between violations of human rights and cultural representations of these violations as well as the measures undertaken to address them. The challenge for ethically-minded scholars, in Pheng Cheah's words, is to read critically in order to identify the underlying "pre-comprehension of the human" (Inhuman 3) and be honest about the "contaminated nature" of the machinery and ideology of human rights (146).

An interdisciplinary approach to human rights-oriented literary criticism is, I think, the most productive approach, and yet the danger of this methodology of intersection and correlation is the potential loss of specificity of unique contexts. For example, postcolonial studies has had an uneasy relationship with Trauma Studies. Although both are interested in representations of suffering and loss, many critics, from both fields, dismiss attempts to bring into conversation African slavery and the agony engendered during the Shoah, citing Western imperial bias on the one hand or the incomparability of the Holocaust on the other. ${ }^{16}$ Others find it productive to engage with the similarities and differences of these two different catastrophes. ${ }^{17}$ Some critics debate whether or not slavery or the Shoah can be represented by art at all, while some artists create art that grapples with representing "the unthinkable, unspeakable, unrepresentable" 
("Human Rights and Literature" 7). Implicit in all of these debates is the worry, often described as the human rights paradox, about representing without doing harm: "how to do justice to the memory of those who suffered, or who were lost [without doing] further violence" (9)? Thus narratives, stories, and works of art and culture struggle to adequately represent human suffering without making it worse. In the Caribbean and African-diaspora context, the neo-slave narrative genre deals explicitly with the legacy of slavery, racism, trauma, the Middle Passage, loss of ancestral knowledge, familial dysfunction and oppression in general; this genre calls for restoring memory and testifying to injustice. Overall, a human rights-oriented approach to Caribbean literature does not shirk the significance of what can be called the human-rights catastrophe of slavery and colonialism. While recognizing that writing cannot heal the wounds of trauma, punish the perpetrators of the slave trade, or adequately compensate the victims, survivors, or their descendants, a human-rights approach highlights the courage of writers who write out of the extremity of slavery.

Yet the legacy of slavery is not the only category of human rights violations that contemporary Caribbean societies and Caribbean literatures have to contend with. In the Caribbean context, other issues include racism, gendered oppression and related violence, systemic poverty, dictatorships and militarism, oppression of queer and trans-gendered people, histories of foreign invasion, redress for indentured labourers and their descendants, fair-wage concerns for the working-poor, redress for Indigenous peoples, and efforts towards transitional justice including truth and reconciliation initiatives. How and for what purpose do contemporary writers from the diaspora represent these issues even if their focus is on past suffering? ${ }^{18}$ From their position of distance and critical 
witness, with their faces turned towards the past in order to imagine a better future, diasporic Caribbean maroon writers play a role of active critique by underlining the ongoing legacy of slavery, indenture, colonialism and the layering of historical traumas that these forces have created.

However seductive an interdisciplinary and intersectional approach may be, scholars cannot idealize the dynamic between literary studies and human rights studies nor unequivocally chart how the fields influence each other. Slaughter warns that "we must resist the easy temptation to instrumentalize one in the service of the other, to bend one to the exigencies of the other" ("Foreword" xiii). And yet, there is no question that "the condition and wager of human rights work itself" and "the influence of literature on human rights may be both immense and immeasurable" (xiii). Slaughter's choice of the word "wager" is apt, too, since the pursuit of human-rights oriented criticism in any field, including literary studies, is fraught with risks. An interdisciplinary approach, such as the one I call for here, also faces the risk of being accused of cultural appropriation and conflation. Yet I believe that an effort to recognize intersectionality, multidirectional memory, the translation and sharing of stories, and the transgression of generic and disciplinary boundaries can lead to a deeper experience of collective accountability and empathy. ${ }^{19}$

The texts examined in the dissertation engage, from their transnational position, with local and diasporic experiences that reflect "alternate modalities, narratives, and ways of articulating political, economic, cultural, and social justice claims that fall outside the national-legal spheres of institutionalized human rights" ("Human Rights and Literature” 10). Similarly Jill Bennett and Rosanne Kennedy write that trauma studies 
"must move beyond its focus on Euro-American events and experiences, towards a study of memory that takes as its starting point the multicultural and diasporic nature of contemporary culture" (5). Accordingly my project attends, from an ethical stance, to literary representations of human rights violations and atrocities, and puts in evidence human rights concerns as part of an ongoing decolonization approach to contemporary

cultural studies. ${ }^{20}$ Moreover, I employ the maroon trope as a strategy to represent literary activism and engagement but also to demonstrate the Caribbean-ness of the writers and texts in my archive and thus counter the European bias to trauma studies. Ultimately then, the writers I study in this dissertation demonstrate the maroon's distance and observational stance from above the plantation as well as their movement away from oppression and towards community, revolution, and liberty. The maroon figure, with its connection to rebellion, dissent, and community-building, is thus a locally-specific corrective to western-approaches to human rights, trauma, and postcolonial studies.

\section{Female Alternatives to the Traditional Maroon Narrative}

The traditional maroon narrative describes violent actions undertaken by a heroic, masculine, Afro-Caribbean resistor to slavery and oppression. In the French Caribbean, we can distinguish between acts of grand marronage, which include permanent flight from the plantation to maroon communities, and petit marronage, generally speaking small acts of rebellion within the plantation including absenteeism (Debien 107, 110-11). Many countries, especially Haiti, Jamaica, and Suriname have adopted the maroon narrative to varying degrees as part of the nation's creation myth, or origin story, and thus the maroon narrative is understood to be at the heart of the country's successful 
independence from slavery and colonialism. Literary examples featuring the traditional maroon trope include Alejo Carpentier's El reino de este mundo (The Kingdom of this World), Patrick Chamoiseau's Texaco, and non-published oral narratives and songs. However, as contemporary maroon narrative theorists have shown, the conventional maroon trope ignores what was often a more complex situation that involved collaboration, accommodation, and collusion between maroon societies and plantation owners, often to the detriment of slaves whose own plans for revolt were often betrayed by maroon informants. Another critique of the traditional narrative is that maroonage was a somewhat privileged or impossible circumstance for many slaves; Jenny Sharpe, for instance, explains how "an uncritical celebration of slave resistance and resilience risks overlooking the conditions of subjugation and dehumanization that in many instances prevented an opposition to slavery, overt or otherwise" (xv). Sharpe underlines that slaves who did not resist their oppressors should not be dismissed by "History" because the opportunities to resist and rebel were not available to everyone. ${ }^{21}$ Unlike men who could more reasonably physically flee the plantations and set up maroon communities, women also often became practitioners of "petit marronage," which involved endemic truancy but also small-scale acts of subversion and rebellion which were, in Richard Price's words, "a constant thorn in the side of the plantation owners" (105). Myriam Chancy's Framing Silence: Revolutionary Novels by Haitian Women considers Haitian literature from a transnational-feminist perspective, and in so doing reframes conventions about the role and value of the maroon figure. Through her focus on literature by women writers, and by evoking a temporal span that links the writers in a matrilineal literary lineage, Chancy underscores the revolutionary power, potential or 
actual, of creative acts such as writing. Cultural producers and artists from other disciplines also offer new perspectives on the maroon and on maroon societies that do not necessarily engage with male military power or aggressive acts of violence. For their part, Caribbean women writers have pursued alternative ways of conceptualizing and deploying the maroon trope. A brief survey of contemporary Caribbean literature written by women reveals the importance of redefining the maroon. Notable examples include Michelle Cliff's 1984 Abeng, ${ }^{22}$ Maryse Condé's 1986 I, Tituba, Black Witch of Salem (translated from the French Moi, Tituba sorcière ...), ${ }^{23}$ and Dionne Brand's At the Full and Change of the Moon, ${ }^{24}$ which give accounts of maroon life on the islands of Jamaica, Barbados, and Tobago, respectively. With their different presentations of female maroons and the historical context of the islands, the novels explore the tensions between female leadership and patriarchal traditions but, ultimately, reveal the inheritance of female resistance, rebellion, and defiance. Overall Cliff, Condé, and Brand offer female-centered alternatives to the male-maroon trope that relate to both petit and grand marronnage. Representing both the Francophone and Anglophone literary traditions, these writers underscore the complexity of maroon life under slavery. They reveal a history of female defiance, but also one of suppression, that has been inherited by the contemporary writers themselves and the characters they bring to life.

\section{Diasporic Maroon Witness}

The authors studied in this dissertation live a doubly-diasporic experience based on separation from original homelands in Africa and elsewhere; diaspora due to maroonage or exile; and diaspora due to immigration away from the Caribbean to another 
country such as Canada, the United States, or France. The writers speak English, French, or a regional creole as their first language, and each writes from the experience of cultural and linguistic diversity due to the contact between Indigenous Amerindian, African, and Indian cultures. Benítez-Rojo writes that "the spectrum of Caribbean codes is so varied and dense that it holds the region suspended in a soup of signs" (2) so that inevitably a "discourse of chaos" ensues from the "historiographic turbulence and its ethnological and linguistic clamor" (3). If the Caribbean region itself is as complex as Benitez Rojo's analogy suggests, then the diasporic experience that results from it is exponentially more complicated, as is the literary maroonage and testimony it produces. The dissertation's doubly-diasporic texts, when read alongside texts written from within the Caribbean region, contribute to a dynamic, expansive portrait of Caribbean literature and what it means to be of Caribbean origin, no matter where one lives and no matter one's multi-cultural, multi-racial, multi-lingual, and multi-ethnic history.

The themes of resistance and defiance run throughout these texts which contest, defy, and resist Western colonial expectations while also offering dissident critiques of mainstream nationalism, racial and cultural identity, history, and genre. The examples from the genres of the long poem, vodou novel, bildungsroman, and post-slavery memoir all ring out with characteristics of a culture of dissidence evident in traditional orature, music, storytelling, even visual art, and resist their categorization as strictly literary. Indeed, the texts considered in this study veritably revolt against their stylistic and generic categories. Although generic innovation is a hallmark of postmodern and avantgarde literature in general, in the Caribbean tradition it signals an attention to cultural diversity, syncretism, and a locally-situated mission of testimony and dissent. 
In addition to providing a perspective from the Caribbean diaspora, the texts present critical voices that demonstrate unease with political and sociological phenomena taking place either in the diaspora or in the Caribbean. Thanks to the distance that diaspora provides, many writers feel able to write and publish their dissenting views; in fact, many writers live in the diaspora because of their dissenting views. ${ }^{25}$ Yet, keeping in mind that queer writers, political activists, and dissenters do continue to live and work in the Caribbean, does a focus on diasporic cultural productions risk effacing the brave writing and revolts that take place "back home"? ${ }^{26}$ This attention can lead to a narrowing of focus, since experiences from the diaspora then become privileged over literary production emerging from within the Caribbean region. Alison Donnell underscores the "strong pull that black diasporic criticism has exerted on the reception of Caribbean writings since the early 1990s" and attempts in her own work to "resist the wake of Black Atlantic criticism by reconsidering the particular relations between the local and the global, the national and the diasporic that need to be attended to" (7). My dissertation responds to Donnell's concern by reading the experience of diasporic maroon witnessing as a simultaneously local and planetary initiative, inspired by the strong local and particular Caribbean history of maroonage, informed by specific places, social contexts, and cultural traditions, and yet open to the wider contemporary and historical diaspora. This dissertation will demonstrate how the locally-informed concepts of haunting/mourning, maroonage, voudou, and the post-slavery narrative are strategically used to show just how intimately local contexts are entangled with global concerns. Ultimately the dissertation emphasizes that the distinction between local and exilic, indigenous and diasporic is unstable, and that although a writer or character may live 
elsewhere, the already-diasporic Caribbean asserts itself in all its chaotic complexity. The experiences of regional and diasporic writers, when taken together, thus contribute to understandings of the twenty-first century Caribbean informed not only by a Black Atlantic, but also by a pan-oceanic, worldwide, diasporic Caribbean.

My work addresses how a distinction between "home" and "away" does not necessarily create or deepen a schism but, rather, with the invocation of the figure of the maroon, can engender a sense of an innovative transnational or translocal Caribbean discourse deployed through multi-relational and multi-directional witness towards the goal of social and cultural decolonization. A key text for the dissertation is the 2013 Postcolonial Witnessing: Trauma Out of Bounds by Stef Craps, which brings into conversation the often divergent fields of trauma theory and postcolonial criticism in order to address the Eurocentric bias that has long plagued trauma studies. Craps promotes a comparative framework for literary analysis that might fulfill the ethical promise that trauma theory claims to hold. Craps argues that "a decolonized trauma theory can act as a catalyst for meaningful change. By enabling us to recognize and attend to the sufferings of people around the world, an inclusive and culturally sensitive trauma theory can expose situations of injustice and abuse, and open up ways to imagine a different global future" (7-8). Engaging in a similar project to restore the connection to trauma theory, Goldberg and Moore write that "reading in the humanities--reading that attends both to literature's invitation to imagine other worlds and other ways of being and that interrogates its own suppositions--remains a crucial balance for the pragmatic work of honoring and protecting the lives of all human beings" (14). Like each of these critics, I am interested in productive critical conversations about the relationship between trauma 
studies, human rights, and postcolonial studies. This dissertation presents literary case studies that explore this dynamic.

Since the writers and protagonists examined in my archive live an experience of double diaspora or multiple diaspora, in this iteration maroonage also involves a different connotation - to be marooned, as in lost, caught in-between, always searching for a safe haven or homeland of origin that is gone or impossible to find. However, as in other examples of maroonage with its inherited legacy of rebellion and dissidence, this position of maroon witness is not one of passivity but rather a posture of potential political action, artistic critique and dissent. Nor is the maroon tradition exclusively Afro-Caribbean in origin; as I alluded to earlier, Indigenous communities all across the archipelago and the Caribbean basin provided the first maroonages and safe havens to escaping African slaves, and it is in these communities that Haitian Vodou and its sister religions developed, including Santería, obeah, quimbois, and candomblé. In contemporary times, the memories and mythology of maroon figures such as Nanny of the Maroons and Anacaona are deployed strategically by different ethnic groups in order to reify specific cultural priorities and identities. The Taino chief Anacaona, for example, is mythologized in oral history as a founding figure for Hispaniola even as her indigenous heritage is downplayed by Afro-Caribbean-dominated politics in Haiti and white-focused politics in neighbouring Dominican Republic. Consequently, contemporary maroon witnessing is not solely Afro-Caribbean in embodiment and representation, but is instead undertaken by Caribbean diasporans of multiply racial and ethnically diverse backgrounds.

Although my preoccupations are not radically different from other diasporic feminist critiques of Caribbean literature, what is notable about my project is the attention 
paid to diasporic Caribbean writing by women from, specifically, a critical human rights perspective, and my contention that genre resistance by diasporic women writers heralds a necessary decolonization of traditional frameworks and engages in a cultural redress project towards the irreparable crime of slavery. The texts explored in this dissertation respond to a need to signal the disappeared stories of lost, suppressed voices of both women and men. Just as many of the texts move and flow between genres and styles, my project foregrounds the movement between diverse people, languages, genders, sexualities, ideas, and literary genres that represent the experience of diaspora. But just as the definition of "maroon" can evoke both resistance and abandonment, both refuge and loss, the ambivalence and simultaneously contradictory experience of diaspora is an apt notion for the dissident and dynamic work of the authors I examine here. It is from within a shared sense of diasporic dislocation that the texts examined in this dissertation were written.

\section{Chapter Outline}

Édouard Glissant's seminal theories of antillanité, créolisation, opacité, and the poetics of relation and tout-monde set the stage for formulations about maroon witnessing, diasporic subjectivity, and a Caribbean planetary consciousness that is global and concerned with the relation between disparate locations, cultures, and peoples. By considering both Anglophone and Francophone texts, I emphasize a comparativeliterature approach that honours the multi-lingual reality of the Caribbean diaspora. As an acknowledgment to this polyphonic region, two chapters discuss French-language texts, all texts include the use of Martinican or Guadeloupian Créole, Haitian Kreyol, or 
Trinidadian patois, and all four chapters refer to critical scholarship written in French and English. While the scope of the dissertation project and my own linguistic limitations prevent me from presenting readings of texts from every creole language as well as the Dutch, Spanish, Portuguese, Hindi, Arabic, Chinese, Danish, Ladino, Papiamentu, and Javanese spoken in the region, my commitment to interrogating literary texts by Anglophone and Francophone writers attempts to respond to the multilingual richness of the region and the far-reaching Caribbean diaspora. As J. Michael Dash argues, "a PanCaribbean critical approach is, arguably, becoming increasingly necessary, as Caribbean writers and artists are more aware than ever before of the shared heritage, parallel sensibilities, and commonality of interests that link them across the region, beyond nation, race and language" (The Other America xi-xii). ${ }^{27}$ Accordingly, the dissertation represents my conviction that a comparative, cross-cultural approach to Caribbean literature is necessary for a complex understanding of how history informs contemporary realities.

Second, each chapter is dedicated to investigating a particular genre. Accordingly, I engage with genre criticism and approach each text with a regard for how innovations in the long poem form, vodou novel, bildungsroman, and post-slavery memoir contend with memory, atrocity, trauma, and political resistance. Ultimately the texts revolt against generic conventions inherited from Europe and pursue an inherently critical stance that honours the maroon tradition. The literature's revolt against genre engenders a writing with an emphasis on ambiguity, ambivalence, and radical experimentation. While in some ways Glissant sees the myth of maroonage as a diversion or detour "characterized by a nostalgia for pure origins" (12), my interest is to see maroonage as an inter-cultural 
example of "a mobile counterpoetics of diversity" that Glissant would equate with antillean opacité, or opaqueness, which relates to that which is impossible to define. Opacity, in Dash's paraphrasing and translation, is "neither an acquiescence to the status quo nor a kind of romantic otherness. Rather, it is characterized by an oppositional and inscrutable impulse that remains latent in the Caribbean imagination" (12). The "interlectal space" of opacité disrupts "a stable, secure plenitude of meaning and [replaces] it with errancy and dislocation--a going back and forth (reversion and diversion)" so that "no ultimate state can either be defined or fixed" (12). For Glissant, opacité can be a powerful form of resistance, and in this dissertation I will turn to opacité as a framework for thinking about the layering and intermingling of identity and culture in the Caribbean, "the impossibility of legitimate lineages, pure racial origins, or reified cultural affiliations" (Burns 102), ${ }^{28}$ so that creolization, maroon witnessing, and Caribbeanness suggest not a fixed identity but one of constant flux, change, and becoming. ${ }^{29}$

This dissertation focuses on literature by women in order to draw out their contributions from under the long shadows of iconic Caribbean male writers including V. S. Naipaul, Sam Selvon, Derek Walcott, Kamau Brathwaite, Aimé Césaire, Frankétienne, Édouard Glissant, Jacques Roumain, Frantz Fanon, Patrick Chamoiseau, Dany Laferrière, Austin Clarke, et cetera.Despite the many notable male writers from the Caribbean diaspora, I purposefully limit my investigation to contemporary women writers. In so doing, I engage with transnational, feminist, and queer theory to contribute an alternative lens to diasporic criticism so that texts by women of colour stop "haunting" the center and instead assert "territory" (Lee 99). ${ }^{30}$ My research also responds to a trend in women's 
writing from the Caribbean, especially from the Francophone Caribbean, of literary works that resist expectations of genre, style, and theme. In tandem with feminist projects of the mid to late twentieth century, women's writing from the Caribbean tends to begin from the familial, intimate, or personal spheres and yet, as I will show, brings forth nontraditional perspectives on cultural and racial identity, death and memory, religion, sex, and family--with potential consequences for the political and social arenas. Additionally, the primary texts of the dissertation respond to radical and queer considerations of gender, sexuality, family, and desire and bring a gendered Caribbean perspective to questions posed by human rights-oriented literary criticism.

In the first chapter of the dissertation, I hone in on the roles, responsibilities, and poetic actions of literary maroon witnesses such as Caribbean-Canadians Dionne Brand and M. NourbeSe Philip. For Brand and Philip, it is not only their location "elsewhere" but also their work of critical, engaged witnessing that both connects them to and is in tension with the traditional male maroon figure. Philip's ZONG! (2008) extends out of the long poem genre to embody a "haunting lifeline between archive and memory" (back matter). ZONG! is inspired by the infamous historically documented mass-murder of Africans on board a slave ship during the Middle Passage; the historical fact and literary representation of $Z O N G$ ! in several other texts articulates a contemporary connection to the economic mechanisms that fed the slave trade and that continue to dominate Western global capitalism today. Moreover, the long poem bursts through its generic conventions to include multidisciplinary collage and elements of orature especially song, storytelling, and music, as well as, significantly, an attention to linguistic fragmentation. Likewise in Dionne Brand's long poem Inventory (2006), the wide lens of the speaker's gaze is 
reflected in the long poem genre itself which is characterized by the use of extended and expanded modes of time and space, multidisciplinary influences, the poetic tradition of the elegy, and self-reflexivity. I argue that the long poem genre is an apt frame through which to posit the notion of a distinctly Caribbean planetary citizenship and a diasporic Caribbean tradition of mourning, one that relates to maroon witnessing. ${ }^{31} \mathrm{My}$ intervention in this chapter suggests that ultimately ZONG! and Inventory challenge conventions within critical human rights scholarship about the role and capacities of the primary testimonial witness, the bystander witness, and the observer witness. I argue that the long poems reveal instead the reality of a shared, global experience of complicity with colonialism as well as, paradoxically, the need for an experience of oppositional mourning that allows for the traumatic and fractured impact of the act of witnessing itself.

Chapter Two, interested in the genre of the novel as well as its limitations, proposes the analytical framework of vodou as an alternative to the critical framework of the postcolonial gothic, especially when considering literary representations of the emotional, spiritual, and psychological legacy of the slave trade. This chapter considers two novels that focus on experiences of mental illness and psychological distress in characters who find healing through Antillean vodou and Haitian Vodou spirituality. In my reading of Gisèle Pineau's Chair piment (2002) and Myriam Chancy's The Loneliness of Angels (2010) I foreground the characters' vulnerable emotional states and argue that their relation to the spiritual and supernatural worlds eventually rehumanizes them and in some way assuages their distress. My analysis of the texts considers the importance and potential of an analytical framework and critical position based on a regional, pan- 
Antillean vodou that is notable for its openness and syncretism with multiple Caribbean religions, cultures, ethnicities, and world views. As I contend, vodou is both indigenous and diasporic, hence more applicable to Caribbean literary criticism than the imported genre of the Postcolonial Gothic. Significantly, this chapter suggests that attention to indigenous spirituality and ethical empathy can lead to a renewed collaboration between trauma studies and postcolonial criticism.

The dissertation's third chapter centers on two texts that revolt against formalist convention so much so that they cannot be definitively categorized as any one genre: Jan J. Dominique's Mémoire d'une amnésique (1984) is a contradictory novel/memoir, obstinately both fiction and fact; for its part, Edwidge Danticat's The Dew Breaker (2004) can be read both as a novel and a collection of linked short stories. Importantly, the novels announce an as-yet under-examined counter-genre: the maroon-witness Caribbean bildungsroman. The linked stories in The Dew Breaker expose the horrors of life under the Duvalier regimes by unraveling a family secret: the truth that a respected Haitian man living in Brooklyn had been the "hunter" and "not the prey" (The Dew Breaker 21). Thematically, the book revolts against conventions with its consideration of the testimony, history, and humanity of a perpetrator of human rights abuses. Danticat's sympathetic portrait of the former tonton macoute M. Bienaimé, along with his daughter Ka's artistic and emotional struggle to understand her father, offers a dissident contribution to debates about memory and postmemory (Marianne Hirsch), ${ }^{32}$ complex victimhood and perpetrator-hood, and the delicate work demanded of transitional justice. In Mémoire d'une amnésique, the narrative voice switches frequently, as does the protagonist's first name. The book, written in the voice of Dominique's alter-ego Paul- 
Lili, traces the protagonist's childhood in Haiti during the Duvalier regime and her eventual immigration to and adulthood in Montreal. With an emphasis on the perils of forgetting, Dominique's account questions the truth possible in a memoir or bildungsroman, the reliability of narrators, and the authority of "History." Despite her desire to forget terrible events, ultimately memory seeps into the mind of Paul-Lili / Dominique and compels her to write. Like The Dew Breaker, Mémoire d'une amnésique is about struggling with trauma, engaging with the memory of survivors and of perpetrators, and contending with the impact of dangerous, critical memory that can reveal uncomfortable truths. My intention with this chapter is to frame and give context to the ongoing debates in memory studies, trauma studies, and human rights studies about the role and validity of perpetrator memory and perpetrator narratives.

My final chapter interrogates the genre of the post-slavery memoir from a perspective interested in the intersections of feminist and queer theory methodologies. In this chapter I consider two post-slavery narratives from the African diaspora that are concerned with the slave trade and the resulting diaspora: A Map to the Door of No Return: Notes to Belonging by Dionne Brand and Saidiya Hartman's Lose Your Mother: A Journey Along the Atlantic Slave Route. Although Hartman has Caribbean roots she identifies as African-American; paradoxically the pairing of Lose Your Mother with Brand's text reveals a wider Caribbean diaspora and more expansive Black Atlantic. By bringing the two works into conversation, I demonstrate how their investigation into the experience of diaspora reveals the lasting and far-reaching emotional impact of slavery and a resulting queer and diasporic unbelonging characterized by grief and rootlessness. Unlike the assumed veracity and legitimacy of the first-person testimonial or 
autobiography, what risks are taken when authors artistically render events at which they were not present? Although the texts by Brand and Hartman could be labeled as either memoirs or post-slavery narratives, they each struggle in different ways against the confines and expectations of these categories. Ultimately, the books reveal an attention to a queer separateness, that is, a space of ambiguity, movement, and affiliation not through belonging but across difference, both in their thematic preoccupations and in their formal qualities. A Map to the Door of No Return moves seamlessly between essays, testimonies, vignettes, and historical accounts to explore Brand's poetics of diaspora. Lose Your Mother is an amalgam of historical and archival research rendered poetically, and Hartman's personal anecdotes, historical facts, archival images, academic research, and travelogue weave around her scholarly investigation into the mechanisms and roots of African slavery.

Ultimately the texts reveal the impossibility of return to an original homeland and thus the endlessness of diasporic unbelonging. Taken together, the two memoirs present a snapshot of the dissertation's project to explore the role of the maroon witness, and show that her particular insider-outsider position twinned with her experience of loss uniquely and urgently informs explorations of history, diaspora, queerness, human rights violations, and memory. The memoirs serve not only as coda to the dissertation's extended interrogation into the work of maroon witnessing but also as a call to arms for a decolonization process that engages with slavery and its legacy in a connective, layered, and robust way that honours the Caribbean's opacité. 
${ }^{1}$ I use the French expression "maroonage" throughout the dissertation to connote the experience of flight,
distance, and dissent characteristic of the Caribbean maroon. Paradoxically "maroonage" also refers to the
home or refuge possible after flight and revolt, and to the communities founded by the fugitive slaves.

${ }^{2}$ Gregory Castle argues that examples of generic resistance gesture to a "struggle with genre" that "guarantees its survival and its relevance" (4).

3 "Je me suis éloigné de cette rumeur intoxicante afin de préserver ces images qui brûlent encore en moi" (126). The translation of the original French here, and throughout the dissertation, is my own work--unless otherwise indicated.

${ }^{4}$ Jana Evans Braziel and Anita Mannur define diaspora as "a dislocation from the nation-state or geographical location of origin and a relocation in one or more nation-states, territories, or countries" (1). In addition to the emphasis on movement, the experience of diaspora is often associated with the privilege of cosmopolitanism and global citizenship, despite the fact that diaspora can result from refugee claims, flight from war and famine, illegal migration, economic desperation, indentured labour, and slavery. Diaspora is thus a vexed term, since even with the associated hardships, immigration necessitates the economic and social freedom to obtain legal documents, pay for travel and moving, and establish oneself away from home. Accordingly, the term "diaspora" connotes a certain wealth and privilege of race and class, and so diasporic subjectivity becomes linked to cosmopolitanism and elitist tourism, a conflation that also limits the impact of loss and the emotional burden shared in various degrees by all diasporans no matter their socio-economic status.

${ }^{5}$ Deleuze and Guattari's seminal work A Thousand Plateaus: Capitalism and Schizophrenia, 1987, elaborates on the earlier articulations about "nomadism" first presented in their 1973 lecture "Nomad Thought." According to Deleuze and Guattari, the nomad "exists as a force, movement, difference, change" and is unfettered by nationalism, borders, and ideological limitations. The nomad is not embodied in any way and is described as a "body without organs" (159); their concept therefore privileges notions of mobility, process, fluidity, and non-attachment. The popularity of Deleuze and Guattari's ideas has led to a preoccupation, in post-structuralist scholarship, to "make maps, not photos or drawings" that elude "capture" by other critics and avoid the "binary logic" that is put forward by "The State" in its attempt to be a "world order" (24). Not surprisingly, Delueze and Guattari's ideas have been taken up by diaspora critics who find alliances between "nomadology" and diaspora's travelling, multi-national subjects who are not bound up by political nationalism and geographic borders. Interestingly, their work is often invoked in relation to Glissant's theories, and vice versa. For more about the relation of nomadism to diaspora and immigration, please see Sarah Phillips Casteel's Second Arrivals: Landscape and Belonging in Contemporary Writing of the Americas.

${ }^{6}$ In order to offer a corrective, Wuthnow recommends the critical work by Cherrie Moraga, Stuart Hall, Chandra Mohanty, and Linda Tuhiwai Smith, whose approaches to concepts like "experience" and "local" are more robust and allow for the engendering of political agency that can contribute to a true social justice-oriented academic discourse for a post-modern, globalized world.

${ }^{7}$ In addition to examples from oral history that suggest the inter-relation of indigenous culture and knowledge, the development of Vodou, and the role of the maroon communities in forging these links, Florence Bellande-Robertson writes that in discussing Haitian identity "we must not obliterate the Amerindians (Taino and Arawaks) who were the native inhabitants of Ayiti. Even though the population of 1 million or so were decimated by the Spaniards within fifty years, a few of them took refuge in the remote hills and thus became the first "maroons," who later mixed with the African Maroons" (111f.17).

Additionally, Dayan highlights how "in 1804 Dessalines declared the independence of Saint-Domingue, recalling the original Amerindian inhabitants when he chose the name 'Haiti,' which means mountainous lands" (23).

${ }^{8}$ In Caribbean Discourse Glissant writes about the distinctive geography that unites the Caribbean and the continent: "Yet there is some continuity between the archipelago and the continent [...] our lands share 
three common spaces: the heights of the Andes, where the Amerindian world passionately endures, the plains and plateaus of the middle, where the pace of creolization quickens, the Caribbean Sea, where the islands loom! I have said in the introduction to this book that the Martinican landscape (the mountains in the north, the plains in the middle, the sands to the south), reproduces in miniature these spaces" (115).

${ }^{9}$ Chris Bongie writes of the paradox between "a given identity and the estrangement from this identity that is inseparable from the experience of creolization" (18). Bongie cites The Pleasures of Exile, in which George Lamming writes of the island landscape that there is "no geography more appropriate to the study of exile" (Lamming qtd. in Bongie 18).

${ }^{10}$ To be precise, Emancipation was decreed in Saint-Domingue in 1793 following the 1791 Bois Caïman ceremony, which is generally credited as the inciting incident of the slave uprising. Since Independence was not decreed until 1804, there were technically no "slaves" fighting in the revolution after 1793. Nevertheless, perhaps because slavery could have been reinstated had the revolution not been successful, scholars tend to describe the resistors during the thirteen years between 1791 and 1804 as "slaves" and their enemies the "master classes," as Sidney Mintz does in the preface to Alfred Métraux's Le Vaudou Haïtien. Marc A. Christophe describes "the Maroon leaders" who "promised their warriors that if they died in combat they would return to Africa" (88). More profoundly, the maroon communities themselves preceded Independence and in many ways inspired the Revolution by offering alternative social models. Gerdès Fleurant writes that "the divide-and-conquer tactic of the plantation owners that drove a wedge between different ethnic/linguistic groups by favoring some rather than others was a factor in the behaviour of the Africans in captivity. Yet people forged bonds of solidarity as Maroons in establishing underground trails that led into the mountains, where they reproduced their social and political organization, at the center of which was the religion practice of Vodun. The plantation workers must have realized that their salvation resided in a strategic unity, a feat achieved in the face of brutal oppression" (53).

${ }^{11}$ Please see Rachel Douglas's article "Haitian Revolutions in Literature: The Case of Linguistic and Visual Inventiveness in Frankétienne" (2008), as well as Elizabeth Walcott-Hackshaw's "Lahens's Revolution, or the Words Within," in Martin Munro's and Elizabeth Walcott-Hackshaw's edited volume Reinterpreting the Haitian Revolution and Its Cultural Aftershocks. See also Patrick Chamoiseau's Écrire en pays dominé.

${ }^{12}$ Cynthia James explores the connection between maroonage and diaspora: "as it stands," she writes, "the bulk of recognized Caribbean writers are literary maroons themselves, living in [...] European, American, and Canadian cities. The maroon narrative focuses, too, on that continual sense, generation after generation, of living in a fabricated home elsewhere" (8).

${ }^{13}$ Dayan discusses the mythical and historical connection between Vodou and Haiti's revolution: "Legend has it that the blood oath of Bois-Caïman began the slave revolt in 1791. In Bois-Caïman a Vodoun service was convened by the houngan (priest) Boukman and a mambo (a priestess) [...] Today the ceremony of Bois-Caiman is one of the most fierce deeds of recollection: it relives the ferocity of the struggle for independence, with the militant Petro deities, whose identities were forged in the New World struggles, at the center of the service. Some Vodoun practitioners say that the loa do not let them forget the tribulations of slavery, and the defeats of the Spanish, English, and French, all those blancs during the thirteen years of revolt" (23). Patrick Bellegarde-Smith writes that Aristide's successor René Préval "declared the significance of Bois-Caïman and the Vodou ceremony that took place there as the signal moment that initiated the Haitian Revolution and the subsequent wars of Independence in a formal decree" (29).

${ }^{14}$ The abbreviation "DOM" is a geo-political designation that stands for "départements d'outre-mer," which translates to "overseas department."

${ }^{15}$ Hunt writes in her introduction to Inventing Human Rights that her study depends on the link between empathy and socio-political life: "reading accounts of torture or epistolary novels had physical effects that translated into brain changes and came back out as new concepts about the organization of social and 
political life. New kinds of reading (and viewing and listening) created new individual experiences (empathy), which in turn made possible new social and political concepts (human rights)" (33-34). Hunt underscores that novels permitted readers to identify with characters who were outside their own social and class realms, and that this fostered a broader sense of empathy and social responsibility: "reading novels created a sense of equality and empathy through passionate involvement in the narrative. Can it be coincidental that the three greatest novels of psychological identification of the eighteenth century-Richardson's Pamela (1740) and Clarissa (1747-48) and Rousseau's Julie (1761)--were all published in the period that immediately preceded the appearance of the concept of 'the rights of man'?" (39).

${ }^{16}$ For more about this complex issue please see Eric J. Sundquist's comprehensive examination of the "black-Jewish question" (2) in his 2005 Strangers in the Land: Blacks, Jews, Post-Holocaust America.

${ }^{17}$ This reference to connections between the Jewish experience and anti-slavery narratives is not an original idea but one that has already been taken up in literary scholarship by critics including Michael Rothberg, Stef Craps, and Sarah Phillips Casteel, and in creative works by writers including Myriam Chancy, Michelle Cliff, Maryse Condé, Lawrence Hill, Michelle Maillet, Cynthia McLeod, Toni Morrison, Caryl Phillips, Philip Roth, Myriam Warner-Vieyra, André and Simone Schwarz-Bart, and Clarice Lispector.

${ }^{18}$ Significantly, Walter Benjamin's image of the angel of history reminds us that global suffering does not exist because of isolated events: "Where we perceive a chain of events, [the angel of history] sees one single catastrophe which keeps piling wreckage upon wreckage and hurls it in front of his feet" (257). Historical suffering is not produced by singular events, as espoused by traditional trauma theory, but rather through an interconnected, accumulated "pile of debris [that] before [the angel] grows skyward" (257).

${ }^{19}$ Michael Rothberg's Multidirectional Memory argues for a comparative approach that relates memories and representations of genocide and colonialism across different cultural and ethnic histories and traditions, and he calls for scholars of human rights violations and historical atrocity to find links rather than perpetuate "competitive memory" that, ultimately, fractures solidarity between groups and ignores common experiences of oppression and persecution. There is therefore a precedent for and a need to build from this conversation in order to consider other contemporary human rights issues in conjunction with diaspora and postcolonial studies.

${ }^{20}$ Important theoretical and methodological frameworks for the dissertation include works that present a comparative or intersectional approach to these topics, including Rothberg's Multidirectional Memory, Stef Craps' Postcolonial Witnessing: Trauma Out of Bounds, Bennett and Kennedy's World Memory: Personal Trajectories in Global Time, Marianne Hirsch and Nancy K. Miller's Rites of Return: Diaspora Poetics and the Politics of Memory.

${ }^{21}$ In the second chapter to Ghosts of Slavery, Jenny Sharpe elaborates on the lives of mulatto concubines in Caribbean slave societies and their experiences of accommodation, collusion, resistance, and mobility. Sharpe writes that "the mulatto concubine appears in colonial narratives as the domesticated and slavish counterpart to the maroon obeah woman" and that in addition to suffering from obvious sexual exploitation the concubine also "achieved a certain degree of autonomy from [her] owners" as well as "mobility" within the system of slavery. Sharpe's discussion of the concubine's "unique" and conflicted position "[introduces] questions of female agency to a site of subjugation" (44).

${ }^{22}$ In Cliff's Abeng, the discussion of maroonage focuses specifically on the female tradition embodied by Jamaica's Nanny of the Maroons, "the small and old Black woman whose only decoration was a necklace fashioned from the teeth of white men" (Cliff 22). Cliff introduces Nanny's history in three short passages each set apart from the narrative. The descriptions are not part of the protagonist Clare Savage's internal narrative. Their placement suggests that Nanny's story is not widely known, indeed that it is repressed, and thus reveals that Clare's society fails to teach her about opposition to slavery and colonial domination. The introduction to Nanny follows a portrait of Clare's great-grandmother Granny, a woman who runs away from her family to live with a former servant, and a description of Clare's grandmother Miss Mattie, a religious woman who leads prayer services for her community. Taken together, the three women could 
contribute to a powerful matrilineal heritage for Clare, but importantly she is refused Nanny's legacy. Cliff provides an account of the historical Nanny: "In 1733, Nanny, the sorceress, the obeah-woman, was killed by a quashee - a slave faithful to the white planters - at the height of the War of the Maroons. Nanny, who could catch a bullet between her buttocks and render the bullet harmless, was from the empire of the Ashanti, and carried the secrets of her magic into slavery" (14). Cliff describes Nanny as "the magician" of the Windward Maroons whose war against the white men raged from 1655-1740; "her Nanny Town, hidden in the crevices of the Blue Mountains, was the headquarters" (14). For the readers of Abeng, Nanny of the Maroons is an example of female resistance and determination. But for Clare, the history of Nanny and of other slave resistors is elusive, secreted away, not taught and not learned. By including Nanny's history in Abeng but refusing to allow Clare access to it, Cliff demonstrates just how deeply colonized her protagonist is. At the mercy of her parents' own race politics and the tangible educational relics of England's colonial history, Clare's upbringing does not grant her a sense of potential revolution or an inspiring historical ancestor. Thus, Cliff's challenge to the traditional maroon narrative differs greatly from Condé's and Brand's, as discussed below. Rather than confronting her protagonists with the possibility of slave rebellion and maroonage, Cliff reveals the occluded history of slave revolt and underscores, instead, its need for resurrection.

${ }^{23}$ In Condé's Tituba, Black Witch of Salem, the Guadeloupian author critiques the misogyny of the heroic maroon myth and also reveals the collusion that sometimes occurred between maroon communities and plantation societies. When in disgrace Tituba is sent home to Barbados after her conviction in the Salem Witch Trials, she learns quickly that there is no place for a woman like her in the Bajan maroons' rigidly patriarchal society. At first Tituba tries to engage with Christopher, the maroon's leader, in planning rebellions and leading the community: "listen," she says, "things have got to change. Let me fight the white folks with you" (Condé 151). But Christopher makes it clear that her role is to be his lover, not his revolutionary partner: "He threw back his head and laughed, the echoes of his laughter mixing with the curls of smoke from his cigar. 'Fight? You're going too fast. A woman's duty, Tituba, is not to fight or make war, but to make love!' "(151). The determined Tituba leaves Christopher's compound and sets out alone in order to pursue an independent path of maroon resistance; eventually, she is able to assert her creative and strategic talents to help young Iphigene plan his own slave rebellion. In her novel, Condé highlights the secret coalitions that existed between slave-owners and maroon communities such as Christopher's, whether on Barbados or elsewhere. As James discusses, maroon societies were often tolerated as long as they worked with the plantation owners to stay abreast of and help put down nascent rebel activity by slaves. In the novel, Iphigene explains the nature of this collaboration and collusion to Tituba: "You don't realize what the maroons actually represent. There is a tacit agreement between them and the planters. And if they want the planters to let them enjoy their precarious freedom, they have to denounce every plot and every attempt at a slave revolt they hear about on the island. So they have their spies everywhere" (163). Unfortunately, Christopher's maroon community betrays the slaves, and the plantation owners put down the slave rebellion and execute all its members, including Iphigene and Tituba. This example in particular reveals the phenomenon of maroon accommodation with plantation owners in order to guarantee safety; Jenny Sharpe elaborates on practices of accommodation and collusion in Ghosts of Slavery: A Literary Archeology of Slave Women's Lives.

${ }^{24}$ Another important example in the tradition of alternative presentations of the maroon is Dionne Brand's At the Full and Change of the Moon, which I will discuss further in subsequent chapters of the dissertation. In the novel, a slave rebellion on Tobago is organized by a slave-woman, Marie Ursule, Here, the rebellion ends in tragedy rather than in the creation of a new free society. The transformative potential of this act of defiance is thwarted by its own enactment, as only two people survive the mass-suicide by poison: Marie Ursule's lover Kamena and her daughter Bola. Marie Ursule is known as the "queen of the Convoi Sans Peur; queen of rebels, queen of evenings, queen of malingerings and sabotages; queen of ruin; who had lost an ear and been shackled to a ten-pound iron for two years after the rebellion of 1819 had been betrayed" (At the Full 5). Though she prepares the consensual death of her fellow members of the Sans Peur Regiment, and prepares herself to be hanged for her organization of the mass-suicide, Marie Ursule also arranges to save her lover and her daughter: "Only her little girl, Bola ... she would send her to Arauc or Terre Bouillante. She would try and send her to the secret hills, to the secret places even beyond those secret hills" (6). Kamena agrees to bring Bola to one of the free maroon settlements he had come across in 
his previous wanderings: "The names of secret places had dropped from Kamena's lips in whispers. Terre Bouillante, Arauc, Casse Terre, Morne Diable, Morne Macaque, Morne Maron” (6). But after they flee from the plantation, Kamena is not able to find the refuge of his Terre Bouillante: "It was as if Terre Bouillante had never existed or as if he needed days of walking and thirst to find it ... he could not arrive at the boiling mud or the impenetrable forest around it. He could not find the closing sky with the birds and macaques ... when he couldn't find it again he was homesick, homesick and homeless, and he wanted to lie on the ground and have it take him" (33-34). Charged nevertheless with bringing Bola to safety, somewhere, Kamena continues on instead to where Marie Ursule used to live, at Culebra Bay. He continues to look for his maroon paradise for the rest of his life: "each corner of the island he doubled and redoubled to reach its interior, trying to find Terre Bouillante ... They arrived at Culebra Bay ten years ago. It was now 1833 and he had not found Terre Bouillante or given up his search even if it only took him farther into his own mind" (54). A maroon paradise is therefore elusive, even impossible for Kamena. As for the child Bola whose "eyes saw too much" (8), her fate is to be both free and enslaved. Just as Marie Ursule's act of resistance deprives her of a mother but saves her from a life of slavery, her solitary and independent life is marked by ambivalence. Brought up by the roaming Kamena whose "mind was all on Terre Bouillante" (55), she nearly loses language, health, and sanity as a result of his obsessive dream of maroonage. Ultimately Bola lives out her days at the edge of the sea and learns how to watch and sing to whales. She has many children with many men, and she scatters her children across the world so that, in homage to Marie Ursule, they can never be destroyed or enslaved altogether.

${ }^{25}$ In Create Dangerously: The Immigrant Artist at Work, Edwidge Danticat describes the work of several dissenting Haitian writers who have been persecuted, censored, or forced to flee Haiti. Similarly, as chronicled in Buller Men and Batty Bwoys: Hidden Men in Toronto and Halifax Black Communities by Wesley E. A. Crichlow, queer writers continue to emigrate away from the Caribbean for their safety.

${ }^{26}$ Literary and scholarly works about the Caribbean diaspora include The Butterfly's Way: Voices from the Haitian Dyaspora in the United States, edited by Danticat; Searching for Safe Spaces: Afro-Caribbean Women in Exile by Myriam Chancy; Black Women, Writing and Identity: Migrations of the Subject by Carol Boyce Davies; and Transnational Negotiations in Caribbean Diasporic Literature: Remitting the Text by Kezia Page.

${ }^{27}$ Dash describes his project in The Other America as trying to "encompass the dynamic relation between individual imagination, national communities, regional destiny, and global history through which new identities are envisioned in an archipelago itself so subject to mythification from the outside" (xii). He states that "literary movements in the Caribbean, even when singlemindedly nationalistic or ethnocentric, have been invariably sensitive to the issue of multiple identities and a regional ethos" (xii) and sees the development of this regional attention in the work of Antenor Firmin, Jose Martí, C. L. R. James, and of course Édouard Glissant.

${ }^{28}$ For more about Glissant's theories, please see J. Michael Dash's translation of Caribbean Discourse as well as The Other America. For applications of Glissant's theories, Lorna Burns offers a useful investigation of the connections between Deleuze \& Guattari's rhizome and nomad theory with Glissant's poetics of relation in "Becoming-postcolonial, Becoming Caribbean," published in Textual Practice.

${ }^{29}$ Please see Bongie's Islands and Exiles for an exploration of colonial and postcolonial novels that grapple with cultural mixing and the violence of the colonial encounter. Overall the book is critical of "essentializing, roots-oriented identity politics" (10) and furthers Glissant's argument that "ours is a creolizing world" (Glissant qtd. in Bongie 10).

${ }^{30}$ Samantha Pinto's 2013 Difficult Diasporas: The Transnational Feminist Aesthetic of the Black Atlantic has much in common with my project: "[Pinto's] archive of largely neglected resources remakes the order of diaspora not just to 'include' women but to constitutively challenge how we conceive and read for signs of race, gender, and transnational geographies, in literature and beyond its imaginative borders" (10). Pinto's study "performs a reconstruction of the possibilities of diaspora studies itself--and its historical coming up in the academy at the intersection of postcolonial, transnational feminist, and Black Atlantic 
ways of reading difference" (10). Like this dissertation, Difficult Diasporas examines texts that engage with genre: "their innovations of language, genre, and form suggest the potential futures of the field as yet unknown, as well as the revision of complicated histories of black women as subjects in and of the academy" (10).

${ }^{31}$ Shadow-texts to chapter one include Derek Walcott's Omeros, which traces the ebb and flow of Hector, Helen, and Achille's relationships across historic, natural, and mythic time and space, and Aimé Césaire's Cahier d'un retour au pays natal.

${ }^{32}$ For examples of contemporary postmemory literary texts please see Art Spiegelman's Maus, Jonathan Safran Foer's Everything is Illuminated, Helen Fremont's After Long Silence, David Chariandy's Soucouyant, and Nancy Huston's Fault Lines. Works that consider perpetrator memory include two new Canadian plays that engage with these issues in a Holocaust context: East of Berlin by Hannah Moscovitch and Corpus by Darrah Teitel. 


\section{Chapter One}

\section{Performative Diasporic Mourning and Maroon Witness in the Caribbean Long Poem: M. NourbeSe Philip's ZONG! and Dionne Brand's Inventory}

I come - albeit slowly - to the understanding that ZONG! is hauntological; it is a work of haunting, a wake of sorts, where the spectres of the undead make themselves present. And only in not-telling can the story be told ...

M. NourbeSe Philip, “Notanda” (201)

One year she sat at the television weeping, / no reason, / the whole time / and the next, and the next / the war's last and late night witness.

Dionne Brand, Inventory (21)

The first chapter of the dissertation considers two long poems that present the figure and stance of the diasporic maroon witness. Not determined necessarily by birthplace or immigration, a diasporic orientation is chosen and assumed, like national or political affiliation; diasporic maroon witnesses inherit the uniquely Caribbean tradition of maroon resistance but, as I will show here, do so within an expansive awareness of the larger transnational world. This chapter, concerned with the genre of the long poem, especially in the Anglophone Caribbean as well as Anglophone Canadian traditions, demonstrates how the openness of this genre embodies the openness of diasporic vision. Moreover, it explores not only the celebratory aspect of diasporic creativity, but also a concern with death, ghosts, and mourning, thus figuratively engaging with both a history and a present that are marked by violations of human rights. In many ways this chapter, in line with the texts, pursues a retroactive truth and reconciliation commission of the imagination.

The long poem genre is important in the Caribbean tradition, with examples including Aimé Césaire's Cahier d'un retour au pays natal and Derek Walcott's Omeros. It is also a preeminent mode of Canadian poetry, taken up by Robert Kroetsch, Daphne 
Marlatt, bpNichol, Michael Ondaatje, Eli Mandel, and Margaret Atwood among others. This chapter, with intersectional and transnational intention, explores long poems written by two Trinidadian-Canadian poets. M. NourbeSe Philip's ZONG! (2008) and Dionne Brand's Inventory (2006) reveal a concern with death and mourning that, in the hands of the diasporic maroon artist, engages with the question of how to grieve ethically yet from a distance. Ultimately the long poems offer a model of poetic maroonage that enables a quiet yet engaged activism appropriate for the phases of grief and Post-Traumatic Stress Disorder that follow from trauma and atrocity.

In her study of the contemporary Canadian long poem, Smaro Kamboureli writes that "by dealing with locality, the self, and discourse in the present tense, the writers of these contemporary Canadian long poems construct a literary form that, paradoxically, defines itself by resisting definition" (xv). The self-referentiality of the genre represents and reveals the poets' intention to work with language until it expresses, albeit imperfectly, the voices and experiences of the suffering subjects of the poems. While Philip engages in linguistic and poetic fragmentation to mirror the breakdown of society and human rights on the Zong, Brand explores the metaphoric personal breakdown of the speaker who, as a proxy figure for a collective, is a mediated witness to the war in Iraq. Taken together the long poems confront the seemingly abstract quality of words so that the poetic language performs its own actions of mourning and also its own breakdown.

Significantly, the poets' concern with the fragmentation of language reveals their contention that the long poem is able to reveal its own trauma. Carolyn Forché writes that "the poem might be our only evidence that an event has occurred: it exists for us as the sole trace of an occurrence [...] Poem as trace, poem as evidence" (Against Forgetting 
31). Moreover, Philip's and Brand's long poems betray the profoundly active emotional work that is part of bearing witness and writing out of or in response to extremity. Philip and Brand engage in artistic struggle in these works and lead by example, so that the readers of ZONG! and Inventory are encouraged to engage critically with the human rights paradox mentioned in the Introduction, concerned with how to represent atrocity without doing more harm. Ultimately each long poem presents the voices of or glimpses of the subjective experience of the injured in an experimental way that reveals layers of suffering alongside layers of complicity. The speaker of each poem engages in an active struggle to bear testimony, and this struggle is represented by the breakdown of language and the language of the speaker's own breakdown.

\section{Performativity and Narrative Archeology: The Long Poem as Wake in ZONG!}

$Z O N G$ ! is a wake. It is a work that employs memory in the service of mourning — an act that could not be done before.

Philip, "Notanda” (202)

In November 1781, somewhere in the Atlantic Ocean between the Gold Coast and Jamaica, at least 150 African slaves were thrown overboard the slave-ship Zong because their value as dead cargo was determined to be worth more than as live cargo. Because the ship had run out of supplies, Captain Luke Collingwood hoped this brutal act would lead to insurance payments to the ship's owners for their "loss" of cargo. If the slaves had died naturally from lack of food and water, the owners of the ship would simply bear the loss, but if the slaves were "thrown alive into the sea, it would be the loss of the underwriters" ("Notanda" 189). Two centuries later, Philip stumbled upon a reference to the event and became obsessed with what happened on the slave-ship. Like other writers 
before her, ${ }^{1}$ Philip was haunted by the spirits of the murdered, those who were spared being thrown over, those of the officials, sailors, crew, lawyers, insurers, and justices who were collectively protected from being charged with murder because the loss was that of cargo, not of human lives. Philip assures the reader that because of the monstrosity of the massacre it is a story that cannot be told, yet she is compelled to intercede so that it can be told; ZONG!, Philip's formally complex long poem based on the event's legal court documents and inspired by the poet's training and practice as a lawyer, is her intervention. Here Philip's long poem gives voice to the ghosts, and Philip even "shares" the authorship of the text with a fictional "ancestor" named Setaey Adamu Boateng. In $Z O N G$ ! maroonage is enacted not in the mornes above the plantations but in the ocean, as well as in the fragmented poetry revealed, by Philip, in the fictionalized voice of Boateng. Philip's excavation of the bones and the names of the murdered slaves defies their intended submersion by colonialist powers; her technique of linguistic fragmentation, like the work of a forensic archeologist, likewise takes apart the whole in order to uncover the reason behind each death. A maroon-inspired engagement compels the acts of excavation and the resurrection of the bones and stories that were supposed to remain submerged. Like the archeologist, the maroon witness uncovers layers of past events and historical traumas in order to reveal and bear witness to the stories hidden below. To engage in this poetic autopsy Philip employs literary excavation techniques, adheres to a poetics of forensics, and prompts the ghosts to speak their own stories. Ultimately ZONG! challenges the reader to witness the unfolding of events, listen to the dead and dying, honour their memory, and contend with a diasporic maroon poetics deeply invested in mourning and grief. 
Kamboureli's On the Edge of Genre explores the "lawlessness" of the Canadian long poem and how "this difficulty, this resistance to generic definition" is in fact what "characterizes the long poem as a 'new' genre" (xiv). Philip's ZONG! is, in Kamboureli's terms, a "multi-encoded text that does not adhere to a single set of conventions" and that involves "interrelationships of various embedded genres" (49). ZONG! is divided into 6 sequences: "Os," "Sal," "Ventus," "Ratio," "Ferrum," and "Ebọra." In addition to these, the publication includes sections entitled "Acknowledgments," "Glossary: Words and Phrases Heard on Board the Zong," "Manifest," "Notanda," and the text of the original legal court case, "Gregson v. Gilbert."

Of all these, the 26 poems in "Os," (the French word for bone), make up the skeleton of Zong--the skeleton of the ship, including mast, keel, prow, stern — but also the skeleton of the long poem as a whole. Each poem in the sequence "Os" is built from the words of "Gilbert v. Gregson." Philip decides to use the legal case as a "word store" or "word bank" and to mine it carefully for all possibilities (191). But as is evident in "Os," it is not just the words of the case but also their spatial relation to each other that matters. Instead of being linked by tendon and ligament and flesh, the bones in these poems are connected by spaces but also by figural water. Philip describes the words as clamouring for space, clamouring for room to breathe. Each numbered poem within the sequence can be read independently or as part of the whole of "Os" and the whole of ZONG!. As is its generic tendency, this long poem reveals a myriad of distinct and different voices. How does one read the poem? Ideally, one must read it in all directions and from all vantage points so that no element is missed. However, this tactic is a 
frustrating one, and so ZONG! is both opaque and onerous because of the complex layers, the cacophony of voices, and the chaos of the whole book.

"ZONG! \#26" is the exception to "Os" and to ZONG! in general because the words of the poem are evenly spaced in a prose poem style. Still, there is no punctuation, there are no capital letters, and, like in the previous poems, there is a lack of grammar and syntax. The word "was" appears 54 times in \#26, often with only 2 other words in between each appearance. Once, in the third line, the word is repeated back to back: "was the was was the need." If "was" is taken out to reveal what lies in between, the text reads thus: "the cause the remedy the record the argument the delay the evidence overboard the not the cause" etc. Each of these words is found in the legal document, in the word inventory Philip uses to craft her poems. ZONG! \#26 then functions as a synecdoche that represents the whole. Yet \#26, like all other parts of $Z O N G$ ! must be taken apart and examined in order to be understood. The word "was," so present in "ZONG! \#26," is unforgettable by its omnipresence. It cannot be ignored. Its various appearances, its repetition, its crowding out of the other words, is suspicious. It is a question word without a question mark: was. Tout court. Does "was" stand in for all the questions and unknowns that plague Philip about the Zong massacre? Does "was" also represent "why"? Where does "was" begin and "why" end? It was so, Philip might be saying, it was so and therefore these things were allowed to happen and so they did, regardless of the question "how was this possible" or "why." Either way, according to "ZONG! \#26," "the negroes was the cause" (45). Here, the was is hauntingly elegiac, marking the past tense and the loss of every individual. 
What is more or less whole in \#26 is fragmented throughout "Os," where each poem is a different attempt to deal with the facts of the documents and with what is available in the word store. The poems of "Os" can be seen as the skeleton for ZONG! since they are made up of the evidence that Philip relies on - the legal document itself. Having examined each bone of evidence in the manner of a forensic archeologist, Philip arranges the bones in order to form a poetic skeleton: "Os." The other sequences grow around and become the "flesh" (200), and the names written "under" the poems imbue them with spirit. The words of the legal document are the evidence - these are the bones that have been excavated, dusted off, and made available for forensic literary examination - and Philip tries to find the order, the skeleton, that can help her to tell the story, as accurately as possible, of the living body and how it came to die. "Os" is the literary expression of Philip's forensic examination. Each poem in the sequence of "Os" reveals a different version or interpretation. The bones are the same, yet each arrangement or poem reveals a different construction and a different vision of the same event. The other poetic sequences "Sal," "Ventus," "Ratio," "Ferrum," and "Ẹbọra" fragment the evidence even more so and rearrange it in startling combinations, allowing and revealing the different polyphonic voices, actions, and events to come through. With "Os," the bones reveal the bare facts of the story, and the sequences that follow reveal the muscles, sinews, and flesh.

In the accompanying essay to ZONG! entitled "Notanda," Philip describes the creative potential of water and its relationship to memory and history: "Our entrance to the past is through memory-either oral or written. And water. In this case salt water. Sea water" (201). Philip writes that memory, like the sea, "appears stationary yet is shifting 
always" and that it is "a haunting, becoming spectral in its nature" (201). The motif and metaphor of the sea occupies a privileged place in Caribbean literature as it does in Caribbean culture in general. From Derek Walcott's poetic manifesto that "the sea is History" to the complex paradoxes of drowning and nourishment, separation and means of connection represented by the sea, in Caribbean literature metaphors associated with the sea teem with the very life below, from algae and fish to the bodies of the drowned. Philip adds that she is haunted by memory and "haunted by generations of skulls and spirits" (201) who reside below the surface of the water.

The sea then, as gateway to the past, propels Philip forward, and it is to the sea that Philip looks for the evidence, stories, and ghosts of the Zong. Trained as a lawyer, Philip looks for textual evidence about the murder. But she struggles to find answers, submerged as the facts are under centuries of indifference and collusion. Metaphorically, Philip strains to raise up the evidentiary wreck of the Zong from the bottom of the sea: What is the word for bringing bodies back from water? From a 'liquid grave'? [...] you can never [be] 'exhumed' from water? The gravestone or tombstone marks the spot of interment, whether of ashes or the body. What marks the spot of subaquatic death? Families need proof $[\ldots]$ they come looking for recognizable clothing and say "I want the bones." I, too, want the bones. (201) In spite of Philip's struggle to excavate facts, the poem becomes evidence of the traumatic event. The poem reveals itself to be the very bones and gravestones that Philip seeks to recuperate as evidence for the un-redressed crime on the Zong as well as for the larger crimes of the slave trade. The poetry of witness is thus a textual and ethical encounter that implicates the poet and the reader as witnesses to the traumatic moment so that "the 
text we read becomes a living archive" (Forché, "Living Archives" 146). For Philip, the lawyer-turned poet, the process of writing $Z O N G$ ! generates a poetic rendering or archive of the submerged facts, skeletons, and legal documents needed to honour the victims.

Philip's intention is not simply to gather the facts but also to perform a respectful requiem and participatory wake for the murdered slaves. ZONG! "employs memory in the service of mourning" (202): the long poem is a ceremony, complete with music and praise-songs, hauntings and crying, and it engages the reader in a ritual of public reckoning, grieving, and mourning. ${ }^{2}$ Philip, as the wake's guide and leader, is the link or conduit between the living and the dead, and she explains in "Notanda" how honoured and humbled she feels to hold this position of medium: "I feel strongly that I need to seek 'permission' to bring the stories of these murdered Africans to light-above the surface of the water - to 'exaqua' them from their 'liquid graves.' Indeed, the stories of all the dead" (202). While writing the manuscript, Philip travelled to Ghana to visit a traditional shrine in the Gold Coast's infamous slave port region, and to speak with priests and elders of the Ewe people. She later also visited the port of Liverpool, England, from which many hundreds of slave ships set sail, and there she poured a libation for all the Europeans who also died or lost their souls on board the Zong. In her role as medium, as in her role as poet, Philip declares her need to "let them offer themselves up" (197); the voices of the spirits of the Zong, she insists, must be allowed to rise from the sea and be recognized.

Diana Taylor makes a distinction between the normative, hegemonic, "supposedly enduring" (19) archival evidence of dominant history and the treasury or inventory of the repertoire: "embodied memory: performances, gestures, orality, movement, dance, 
singing--in short, all those acts usually thought of as ephemeral, nonreproducible knowledge" (20). In the case of the Zong, Philip re-affirms the embodiment and human experience of those who died, thereby resurrecting their dignity from the archival evidence of legal history, in short also drawing attention to the limits of the archival evidence. Hirsch extends Taylor's concept to write that "the bodily, psychic, and affective impact of trauma and its aftermath, the ways in which one trauma can recall, or reactivate, the effects of another, exceed the bounds of traditional historical archives and methodologies" (Generation 2). As in ZONG!, repertoires can include stories, "testimony projects and oral history archives" (2), in addition to performances and renderings in art.

While it might be empirically impossible to compare the efficacy of the archive with that of the repertoire, nevertheless Taylor underlines the importance of the repertoire of performance and corporeality as a means for storing and transmitting cultural and historical knowledge that might otherwise be lost: the repertoire, as effectively as the archive, can make political claims, transmit traumatic memory, and forge new cultural identity. Embodied memory, metaphorically stored in a corporeal repertoire of movement and memory, offers a critical alternative parallel to those written and safeguarded within mainstream, institutionalized historical archives. In fact, Taylor asks "whose memories, traditions, and claims to history disappear if performance practices lack the staying power to transmit vital knowledge?" (5). Because Taylor sees discovery and conquest as the dominant dramas that haunt the Americas, her work is especially useful when considering situations of transnational contact and conquest including the postmemory of the slave trade in the Caribbean. 
With ZONG!, Philip's efforts to embody the disjointed, impersonal words found in a historical archive involves an attention to the possibility of an inverted process. Here the action of writing, reading, and speaking poetry might bring sentient life back to otherwise impossible-to-hear long-dead, submerged voices. Philip's embodied experience of interaction with the spirits of the Zong, in addition to her attempt to physically honour them, contributes to their memorialization. Taylor writes that unlike the archive, "the repertoire requires presence: people participate in the production and reproduction of knowledge by 'being there,' being part of the transmission [...] the repertoire both keeps and transforms choreographies of meaning" (20). By seeking the spirits' permission to be a witness to their stories, and by listening to the voices of the ghosts, memory and the trace of the trauma are thus corporeally inscribed, and the poet's own body becomes part of the repertoire of memory about what happened on the Zong. In the long poem the Middle Passage and the sea are simultaneously a graveyard and womb for Philip's poetry and for the ghosts of her story. The undersea world is thus ripe with life and creative potential: not only for ghosts and stories, but also for Philip's poetic rendering. In an interview, Philip was asked to elaborate on the importance of the legal text she used to write ZONG!. Philip responded that "the archive of the owner and the lawmaker--is in fact the only marker. As I say in "Notanda," the text, that is, the reported case, is like a gravestone, and in shattering that gravestone the voices are freed" (Saunders 69).

Paradoxically, the textual, legal, and archival documents unleash the voices and spirits of the dead and make possible a wake in their honour. Ultimately, Philip takes the legal archive about the Zong and renders it poetically and corporeally in order to show what is missing from that archive. 
A wake in itself is a performative event, a ritual that requires a type of active participation that is, ironically perhaps, a lively activity. In the Caribbean region in general, and in Philip's native Trinidad and Tobago in particular, wakes are rousing, boisterous affairs with music, hymns, rum, food, card games, and "ole talk" (Espinet 214). A festive atmosphere is necessary to ensure that the spirit of the departed crosses over safely to the other side. In ZONG!, the wake is also a kind of public forum, in which the voices of the dead themselves clamour to say their piece about what took place on the ship. Unlike Inventory's quiet distress and meditative regard, ZONG! is loud with shouts, anguish, guilt, excuses, shame, lust, greed, fear, disgust, and desire. In ZONG! the spirits of the dead participate in their own wake. Although the names of the dead are printed at the bottom of "Os"'s pages, as if below the surface, the spirits also have their own unique sequence or movement in "Ẹbọra." The pages of "Ẹbọra," printed to look like watermarks, also resemble the doubled layers of printed paper that Philip's printer made, mysteriously, each time she tried to print the drafts of "Sal," "Ventus," "Ratio," and "Ferrum": "the laser printer for no apparent reason prints the first two or three pages superimposed on each other-crumped, so to speak-so that the page becomes a dense landscape of text" (206). Philip's pages are haunted, it would seem, by the story and its voices.

"Ẹọra"s formal construction reflects Philip's interest in finding a way to narrate the story without traditional characters or narration. In an interview with Philip, Patricia Saunders asks "But what is the language that would give voice to this kind of agony? What words can describe their experiences?" (65). In the case of ZONG! the long poem's use of voice and the represented ghostly presence of the dead attempt to address the very 
un-narratability of the massacre. Consistent with poetry of atrocity, albeit with the distance of several hundred years, Philip's long poem reveals the events on the Zong as belonging to "a region of the devastated consciousness--of barbarism and the human capacity for cruelty and complicity with evil" (Forché, "Living Archives" 145). Philip pursues a similar question to that asked by Ariel Dorfman in his poem "Vocabulary": "But how can I tell their story / if I was not there? / Let them speak for themselves" (Dorfman qtd in Forché, Against Forgetting 614-617). Through the rhetorical trope of prosopopeia, in which an absent other is given voice, invoked, or engaged in conversation, Philip attempts to release the Zong's cry of agony and "[tell] the story that cannot be told" (ZONG! 65).

Kamboureli discusses the performative nature of the long poem: "The linearity of narrative now takes the form of a dialogue between different levels of discourse and genres that tend to privilege an awareness of the writing act, while speech still maintains its significance through the voice's textuality" (103). It is these acts of discursive enunciation that for Kamboureli ensure the long poem's performativity: "In conflict with its resistance to an all-descriptive generic definition, the long poem's specificity with regard to its components presents its disjunctiveness as the site of performance" (103104). When Kamboureli speaks of performativity she relies on the discourse of linguistics and semiotics alone. Yet long poems like ZONG! are deeply and self-consciously performative in an artistic way as well: the poem is theatrical and musical, and these aspects contribute to how it can be read and experienced; Philip herself describes it as a fugue. She writes that "in the musical sense of the word, ZONG! is a counterpointed, fugal anti-narrative in which several strands are simultaneously at work" ("Notanda" 
204). Each voice can be graphed or charted as if onto a musical score, so that each line of melody represents the distinctly pitched voice of each character. Each character expresses his or her own drama of little events, conflicts, experiences, and actions; taken together as a complete score, the chaotic life on the Zong becomes imaginable for the reader.

While Philip in no way attempts to recreate in a realistic way the experiences on the Zong, she does highlight multiple perspectives in order to underline the cacophony, dissonance, and concurrence of the different voices aboard the ship. The long poem's sequences are thus fugal movements that each elaborate on a theme: "In the classic, fugal form the theme is stated then reiterated in second, third, and subsequent voices. In a similar fashion $Z O N G$ ! is a sustained repetition or reiteration of various themes, phrases and voices, albeit fragmented" (204). ZONG!'s complexity, challenge, and uniqueness partly relies on the multitudinous cacophony of its polyphonic voices. These voices, of Europeans and of Africans, of the living and the dead, representing conversations, lists, cries, and laments, all "rise from the ocean floor" (203) in counterpoint to better reveal each other and finally to be heard.

In her conclusion to "Notanda" Philip writes that "ZONG! is song" (207). Indeed it cannot be otherwise, and yet the song that is $Z O N G$ ! is not normative or stylistically traditional. Instead it is diverse and complex: it is "chant! Shout! And ululation! ZONG! is moan! Mutter! Howl! And shriek! ZONG! is 'pure utterance.' ZONG! is Song! And Song is what has kept the soul of the African intact when they wanted water ... sustenance ... preservation" (207). By highlighting the musicality of the poem, the performativity of $Z O N G$ ! becomes clear, as does the participatory element. In brief, the wake that Philip invites the reader to is one in which every attendee, whether they be 
poet, ghost, or, just as urgently, reader, is involved. The performativity of $Z O N G$ ! and the interaction and implication of the reader as well as the poet is a potent corrective to the abstract "spectral turn" of contemporary literary criticism. ${ }^{3}$ This long poem is a flamboyant and defiant manifesto against the disembodiment of the archive, theory, and literary criticism. Although Philip seeks inspiration in a legal and physical graveyard below the surface of the sea, and in the nameless souls thrown overboard the ship, ultimately $Z O N G$ ! is an exuberant wake.

Fundamentally $Z O N G$ ! is engaged in the labour of mourning, and the poet attempts to grieve the "ungrievable" lives of the victims who, at the time of the massacre, did not "count as human," did not "count as lives" (Butler, "Violence, Mourning, Politics" 20). But with ZONG!, Philip decides for herself "What makes for a grievable life" (Butler 20). In "Notanda" the poet describes the despair she felt when she learned that the names of the murdered slaves on the Zong had never been recorded: "The African men, women, and children on board the Zong were stripped of all specificity, including their names. Their financial value, however, was recorded and preserved for insurance purposes, each being valued at 30 pounds sterling" (194). Philip wished she had their names in addition to their bones. With nothing physical to mourn and cry over, how could the poet properly grieve their deaths? "I want the bones," she laments (201). Stories and legends exist about the Middle Passage; if you drowned at sea your soul would return to Guinea, or Guinin, which in New World diaspora mythology refers both to Africa and to Heaven. ${ }^{4}$ In "Children of the Sea," Edwidge Danticat writes about Agwe, the spirit of the water, as well as the spirits of the "children of the sea," those Africans who never made it across the Middle Passage and, by their death, were paradoxically 
freed (20). ${ }^{5}$ In Danticat's story, the spirits of the long-dead African slaves welcome with open arms the contemporary Haitians who drown en route to Florida as they try to flee their country's oppressive dictatorship.

Philip's search for the names of the Africans onboard the Zong could only be fruitless, of course, because "they didn't keep names" ("Notanda" 194); authorities rarely recorded the identities of either the drowned or the surviving slaves, noting only gender, approximate age, fitness, and other characteristics relevant to their value as labour. Philip attempts to reclaim and rename the murdered slaves, and also to connect the descendants of slavery to their lost ancestors, by including in the book the "footprints" of the murdered. The poet inscribes names at the bottom of each page in "Os," below the surface of each of the 26 poems that make up the sequence, and these total 150 names, one for each person murdered on the Zong. The names create their own poem as the sounds and letters accumulate like mounds of sand on the ocean floor. Some poems have several names, some only a few, and some names are repeated. Though it is clear that Philip includes these names to stand in for the dead, it is not evident where the names come from; if no records exist of who was on the Zong, it is not clear how she found or chose the names. Do the names represent the survivors as well as the drowned? Are they common names from regions likely to have lost people on the Zong or are they names derived from people who survived the Middle Passage? Ultimately, these speculative questions point to the overwhelming ambiguity of the poetic project. In "Notanda" Philip describes why she includes the names: "The Africans onboard the Zong must be named. They will be ghostly footnotes floating below the text— 'underwater ... a place of 
consequence' $[\ldots]$ acknowledgement — someone else was here before [...] footnote equals the footprint. Footprints of the African on board the Zong" (200).

Philip titles the final sequence of $Z O N G$ ! after the Ebọra, the underwater spirits, such as the African and African-diaspora spirit Mami Wata, who live in the ocean. This poetic sequence is printed to look like an extended watermark: the pages are faded and water-logged, and the fragments of text layer upon on each other like strands of seaweed and kelp. In "Os" the Ebọra, the water spirits, also live and assert their presence by way of their footprints and by their names. They lie below the surface of the poem but they are not silent: they expect to be pronounced and heard. These Ebora compel the reading of the poem, accompany the reader along the pages of the sequences that follow, and pursue the reader beyond the pages of the book. Consequently ZONG! engages the reader in an active ritual of mourning. Whereas other aspects, sequences, even whole pages of the poem are opaque, the simplicity of the names' presence ensures that they are noticed, remembered, and read.

Again, the maroon witness shares with the literary archeologist the impulse to pursue the recovery of voices and stories. Figuratively, the footprints and names are symbolic of Philip's larger project in ZONG!: by diving for and discovering the bodies and names of the victims, by excavating them from the muddy waters and kelp-covered archives, Philip can testify to the lives, experiences, and murder of these 150 Africans. With the names as footprints running along the pages of "Os," demanding to be evoked and spoken out loud, and with the waterlogged "Ẹbọra" as the book's finale, Philip invites the reader to engage in a process of public mourning for the lost captives of the Zong. The names become a key element to a mourning ritual meant to be spoken aloud; 
the wake that is ZONG! thus becomes participatory, vocal, physical. The readers become the public mourners, and Philip is the ceremony's leader.

\section{Breakdown of Language, Language of Breakdown in ZONG!}

In the many silences within the Silence of the text. I would lock myself in this text in the same way men, women, and children were locked in the holds of the slave ship Zong.

Philip, "Notanda" (191)

Poetic fragmentation, writes Forché, "has a venerable history” in literary

modernism and especially in poetry of extremity, where "it might well be the feature that binds [poetry of witness] together" (Against Forgetting 42). Fragmentation in ZONG!

occurs through Philip's use of archival material, the poem's reduction of standard English to choked gutturals, the incomprehensibility of its plot, and the disturbing evocation of the cries and moans of the massacre itself. Philip's work in ZONG! attempts to commemorate the victims, indeed announce their wrongful deaths, and, in so doing, indict the murderers. The poet attempts to make the lives and deaths of the victims grievable and worth remembering by performing linguistic violence against the genocidal legal document:

I murder the text, literally cut it into pieces, castrating verbs, suffocating adjectives, murdering nouns, throwing articles, prepositions, conjunctions overboard, jettisoning adverbs: I separate subject from verb, verb from objectcreate semantic mayhem, until my hands bloodied, from so much killing and cutting, reach into the stinking, eviscerated innards, and like some seer, sangoma, 
or prophet who, having sacrificed an animal for signs and portents of a new life, or simply life, reads the untold story that tells itself by not telling. ("Notanda" 193-194)

In ZONG!, the poet is simultaneously both a secondary witness, with several hundred years of diasporic distance between her and the massacre, as well as a contemporary maroon figure who actively participates in and engages with the untold story. Philip positions herself as a witness to the voices of the Zong's captives. In so doing, she endures a wounding of her own as she takes in the imagined testimony of the captives and renders it into poetry. Philip's witness posture demands effort, empathy, and the acknowledgment that restoring dignity through art cannot undo the crime nor bring Philip herself to the position of immediate witness; she can listen, but she was not there.

In a choice that reveals her attempt to approximate the event of extremity itself, Philip composes the poem according to a strict framework: she commits herself to using the material she finds in the text of the legal case Gregson v. Gilbert. This limitation brings attention not only to the massacre itself but also to the British judicial system's explicit and implicit sanction of the event. Philip wants to use the case to the exclusion of other archival material because it is, for her, "the one public moniker of the murder of those Africans [...] a public monument, a textual monument marking their murder and their existence" (194). Ultimately Philip is interested in letting the words speak for her, in trying to let the story unfold without too much authorial intervention.

Yet Philip invariably makes authorial choices that are reflected in the book's spatial organization, graphics, and typesetting. These are editorial choices, not examples of total surrender to whatever the words reveal, since even a seer like Philip interprets 
what she sees. Most profoundly, Philip's "non" choice is indeed her greatest act of authorial intention: by choosing Gregson v. Gilbert as her primary source material, she begins to excavate it as carefully as she can - and this gives her leave to begin to take it apart. Paradoxically, Philip's use of an archival document allows her to restore embodied dignity and voice to the otherwise undocumented victims. In Taylor's terms, the poet uses the archive to access the repertoire and, when taken together, the picture of the event gains clarity. And yet the focus on the archive also reveals its limitations. Gregson v. Gilbert reveals that the Africans aboard the Zong, just like those on other slaving ships, were valued as nothing more than cargo. The legal document records only their worth, not the merit of their living, as 30 pounds sterling each. Because the murdered Africans onboard the Zong were irrelevant to the sailors and owners, their deaths were not even considered murder, let alone atrocity, massacre, or genocidal act.

Philip describes that in crafting ZONG! she used the legal document "as a sort of grand boggle game and set to trying to find words within words" (200). Gregson v. Gilbert is thus "a matrix - a mother document" that she uses "to explode the words to see what other words they may contain" (200). Philip writes that by privileging the text and finding her poems from within it she becomes "absolved" as a writer, because by using the words of the court case she gives up her "authorial intention." Her attempt to let the ghosts speak reveals her intention to privilege the voices of the victims rather than her own. This commitment reflects Philip's awareness of the human rights paradox of representation, and it echoes Krista Ratcliffe's development of the concept of "rhetorical listening" in witnessing and in scholarship, an approach to listening and engaging that involves the generosity and humility of "standing under" rather than the presumption of 
"mastery" over an experience that is not one's own (28). Although Philip is the only author discussed in this dissertation who shares the author credit with a fictional character, each embodies the witnessing from a distance that is typical of the maroonfigure.

In an attempt to represent the chaos of the frenzy, fear, misunderstanding, and clamour aboard the Zong, many of Philip's poetic moves are opaque and challenging. One technique that is less obscure is the use of spacing for the graphic arrangement of the poems. Philip writes that "all the poems — need a great deal of space around them — as if there is too much cramping around them, as if they need to breathe" (194). Consequently the words of the poem are separated by space above, below, and on the sides to give them room "to breathe." But these spaces also let in water, and in some poems the words seem to float like "so much flotsam and jetsam" (195). Several poems look like aerial views of a graveyard, with each word a tombstone separated by ground and space, never touching the next tombstone. They can be read as individual markers or as part of a figural "counter-memorial" to a mass atrocity. ${ }^{6}$

The voices of $Z O N G$ ! need the spaces embedded in the poems in order to breathe, to catch their breath, even as they cry out and haunt the poem. Philip explains that the poem itself "is revealed only when the text is fragmented and mutilated, mirroring the fragmentation and mutilation that slavery perpetrated on Africans, their customs and ways of life" (195). Philip's strategies of literary fragmentation lead to a recovery of a pre-verbal expression of suffering and pain:

for the very first time since writing chose me, I feel that I do have a languagethis language of grunt and groan, of moan and stutter - this language of pure 
sound fragmented and broken by history. This language of the limp and the wound. Of the fragment. And, in its fragmentation and brokenness the fragment becomes mine. Becomes me. Is me. (205)

As Philip explains, "Ferrum" is the culmination of her struggle to take back English; with that sequence, she felt able to express herself fully without being held back by the language that had previously limited her.

In ZONG! English's viciousness is simultaneously avenged and exposed by the rupture of the words in the legal document. Philip sees the English language as profoundly racist, anti-African, and Eurocentric. As she writes in the earlier poem "Discourse on the Logic of Language" in the collection She Tries Her Tongue, Her Silence Softly Breaks, "a foreign anguish / is english— / another tongue / my mother [...] English / is a foreign anguish" (58). Philip explains that because of its engagement with the slave trade and colonialism, the English language itself is injured and harmed: "No language can accomplish this — and to a large degree English did — without itself being profoundly affected, without itself being tainted" (19). I see Philip's understanding of English as similar to the situation of the German language during and after the Shoah. George Steiner writes that German became "a language being used to run hell, getting the habits of hell into its syntax" (Steiner qtd. in Forché, "Living Archives" 142). Steiner explores the catastrophic effect of long-term atrocity on a language and, subsequently, on a culture:

But there comes a breaking point. Use a language to conceive, organize, and justify Belsen; use it to make out specifications for gas ovens; use it to de- 
humanize man during twelve years of calculated bestiality. Something will happen to it $[\ldots]$ Something of the lies and sadism will settle in the marrow of the language. Imperceptibly at first, like the poisons of radiation sifting silently into the bone. (142).

Poets of extremity write their poetry "not after such experiences, but in their aftermathin languages that had also passed through--languages that also continued to bear wounds, legible in the line-breaks, in constellations of imagery, in ruptures of utterance, in silences and fissures of written speech" (Forché, "Living Archives" 136-137). In this way Philip's linguistic preoccupations are reminiscent of other poets of extremity who strive to represent inexpressible horrors in the very language that gave the orders, in the language responsible for the invention and use of the gas chambers and the chains. Importantly Philip is committed to using English just as Paul Celan insisted on writing in German; Celan "attempted to purify the tongue, render up its Nazi contamination, mark it historically. His quest led him to write in a fragmented, idiosyncratic dialect of his own construction, whose grammar was as tortured as its words were often new" (Forché, Against Forgetting 44). By using the colonizer's and the slavers' language, Philip can claim her space in it, her legitimacy, and in so doing work to mark the rupture of language and reclaim the lost self-expression that the slaves suffered.

Philip's commitment to fracturing the colonizer's language in $Z O N G$ ! is not a new strategy: rather, it has been a feature of her poetics since She Tries Her Tongue, Her Silence Softly Breaks and that collection's accompanying critical essay "The Absence of Language, or How I Almost Became a Spy.” The poetic project of linguistic revenge in She Tries Her Tongue has been well documented by literary critics since the collection's 
publication in 1989. Philip writes that the compulsion to confront English is common amongst descendants of the diaspora: "The place African Caribbean writers occupy is one that is unique, and one that forces the writer to operate in a language that was used to brutalize and diminish Africans so that they would come to a profound belief in their own lack of humanity" (19). Philip belongs to a tradition of Anglophone Caribbean and postcolonial writers who struggle against English despite or because of the fact that their discovery of and initiation into literature was, for many of them, through English in a colonial education system. In contrast, Derek Walcott and V. S. Naipaul express gratitude for their colonial Anglophone educations. In Philip's opinion, it is only after transforming English that writers of African descent will be able to use it without harming themselves: "the language as we know it has to be dislocated and acted upon—even destroyed—so that it begins to serve our purposes" (19). Philip is fueled by the hope that English can be restored. As Celan noted about German, language is not impossible to redeem, despite a long road to recovery: "One thing remained attainable, close and unlost amidst all the losses: language. Language was not lost, in spite of all that happened. But it had to go through its own responselessness, go through horrible silences, go through the thousand darknesses of death-bringing speech" (“Speech at Bremen”).

Philip's project to render English into a language marked by loss from which people of African descent can truly speak develops from She Tries Her Tongue to culminate in $Z O N G$ ! Here the linguistic disturbance serves three primary purposes: to avenge the murder of the Africans on the Zong in particular and in the larger slave trade in general; to find the truth in the words of the legal document; and to reveal the English language as tainted. The utterances, moans, and incomprehensible poems that result 
undermine the authority of English: "The attack must be made at the only place where any true change is ever possible — at the heart of the language" ("Absence” 19). In ZONG!, Philip attempts to use English to turn in on itself and undo itself. With the dominion of English figuratively and poetically attacked in this way, it is no surprise that Philip feels a sense of liberation and freedom in working on ZONG!, especially with "Ferrum," the most abstract and dangerous of the long poem's sequences. Here, English is proven to be nothing more than utterances and sounds, vowels and consonants: "grunts, plosives, labials" ("Notanda" 205).

Philip confesses that she discovers English to be more accessible to her when it has been taken apart and revealed to be broken. What she knows to be her true original language is not a language of praise words, enthusiasm, delight, or victory, but rather a language of suffering, so that in fact English finally matches Philip's experience of racism and cultural brutality. As she explains in an interview, this language is the closest she has ever come to finding her own true voice, even within the colonial frame of English:

It was as if I was finally getting my revenge on something that had fucked me over for so long, that I felt that this broken, stumbling thing that "Ferrum" is, is my very own language. For the first time in my writing life, I felt, this is my language - the grunts, moans, utterances, pauses, sounds, and silences. I feel that now in a powerful sense. ("Defending" 71)

In addition to the variously fragmented English, the many different African languages used in ZONG! work together to reveal the vast geographical and cultural reaches of the slave trade as well as the extent of the chaos on board the slave ship and the profound lack of understanding that must have been in place. If so many languages were spoken, 
wonders Philip, how could anyone have understood what was happening on the ship? Philip chooses to immerse a twenty-first century reader in an experience of that linguistic confusion. Ironically, the language that Philip suggests is most understandable to all, both on Zong the ship and in ZONG! the book, is the preverbal sound of human suffering at its most deconstructed.

\section{Inventory: A Ruttier for Mourning}

At least someone should stay awake, she thinks, / someone should dream them along the abysmal roads.

Brand, Inventory (26)

Dionne Brand's Inventory (2006) unites the poet's activist priorities, her personal history, her attention to historical and contemporary suffering, and her commitment to interrogating her own participation in social-justice struggles. Inventory questions its own literary form even as it moves across space and time. The poem has a wide scope and an expansive site of concern; Inventory has been discussed by Diana Brydon as a contribution to "planetary humanism" (999), by Cheryl Lousley as related to global ecological justice, and by Brenda Carr Vellino as preoccupied with the "precarity archives of disregarded bodies subject to violent death in Iraqi war zones and in transnational border and deportation zones" (243). My intervention, although indebted to the work of these and other writers, underscores the notion of a distinctly diasporicCaribbean planetary citizenship and the work of the maroon witness.

Rather than focusing on how Inventory responds to the Black Atlantic or to critical race critiques in Canadian society, as in traditional critical approaches to Brand's oeuvre, I am interested in how this long poem develops a mourning-centered elaboration 
of diasporic maroon witness also articulated in her novel At the Full and Change of the Moon and her memoir A Map to the Door of No Return. As the speaker of Inventory watches the news unfold from the War in Iraq, she struggles to keep up her "vigil for broken things" (Inventory 42). In so doing, she engages in diasporic maroon witnessingan action and position that is, in part, the result of the specifically Caribbean experience of diaspora: diaspora from an original homeland in Africa, diaspora due to maroonage, diaspora due to immigration away from the Caribbean. In this iteration, maroonage also involves a different connotation - to be marooned, as in lost, caught in-between, always searching for a safe haven that is gone or impossible to find. As in other examples of maroonage with its inherited legacy of rebellion and dissidence, Brand's diasporic maroon vigil is an engaged posture of potential action. In Inventory the experience of maroonage is shaped by an emphasis on diaspora that ultimately expands onto a planetary understanding of accountability, despite the speaker's usual stance as a deceptively stationary television-viewer.

Before turning to Brand's maroon project in Inventory, I would first like to draw a comparison between Philip's method of decolonizing poetic violence in ZONG! and Brand's attention, throughout her oeuvre, to a similar poetics. At the conclusion to $A$ Map to the Door of No Return, Brand describes how she came to use an artifact from the slave trade to give a title and a structure to the manuscript of At the Full and Change of the Moon. While visiting the Tobago historical museum in Scarborough, Tobago, Brand came across a centuries-old set of navigational instructions for navigating to the island. Written by geographer Thomas Jefferys, the instructions describe the landscape and waters of the island of Tobago to King George III and explain where the arriving slave 
ships should drop anchor. Brand decides to use this navigational manual to render the landscape in At the Full and Change of the Moon: "I use Jefferys' observations not as he had, to show the way to slavery, but to sail my characters into the late twentieth century. The unholy paradox of it does not escape me" (Map 203). Brand writes of the strategy, the act of resistance and defiance, that she engages in when she usurps Jefferys' words and intentions:

Language is so wonderful, so deceitful. Which is why 230 years later I wrench it from his pen, I tear it from the wall of this museum, I cut it into pieces - one piece for the title of this novel, At the Full and Change of the Moon, and the rest I give to my Kamena, who escapes the slave plantation at Mon Chagrin in this novel and who in this novel is searching for Terre Bouillante, a maroonage; who is searching in this novel for a place he will never find $[\ldots]$ He never finds what he is looking and longing for, it eludes him, it dissembles, all of his directions lead him nowhere. (Map 202)

Brand's use of Jefferys' words and ideas is nothing short of vengeful theft. Like Philip who uses documents of "justice" to scream out the very lack of justice, by wrenching and tearing Jefferys' words from their original context, Brand attacks the colonial insolence that comes through in the language of his prose, just as she retaliates against Jefferys' intended purpose to guide the arrival of slave ships.

In At the Full and Change of the Moon the geographical and physical terrain of Tobago plays a critical role. The novel's opening chapter is set on a plantation, where Marie-Ursule is making the final preparations for a massive suicide pact she has organized for herself and her fellow slaves. Before the slaves take the poison she has 
prepared for them, Marie-Ursule sends her young daughter Bola, along with her beloved Kamena, into the hills in search of safety. They intend to seek refuge in the maroon camp at Terre Bouillante which Kamena had stumbled upon once before, but he is never able to locate it. His search for the maroon haven of Terre Bouillante takes him to places named by Jefferys, but these places are rendered by Brand as illusory Edenic maroon refuges. Later, Kamena's quest for maroonage will be repeated endlessly by Bola's diasporic descendants. Brand writes that "Kamena's unending and, as history will confirm, inevitably futile search for a homeland is the mirror of the book's later generations - their dispersal, their scatterings to the extreme and remote corners of the world: Amsterdam, New York, Toronto. Their distraction and flights resound in him and back to him. It is their condition of being" (Map 202-203). For Brand then, both maroonage and diaspora have their origin in the passage through the Door of No Return and in the slave trade itself. The two experiences are distinct, and yet they both result from the wrenching of the slaves from their history and memory, from the violent severing of people from their lands, from the indescribable exile and horror of the Middle Passage and slavery.

In Inventory, the Door of No Return metaphorically opens wide to include a larger world, one marked by the atrocities and wars of the late twentieth century; this perspective is surveyed by a solitary witness who, over time, is herself fragmented by what she observes. The speaker's extended gaze in Inventory is characteristic of the long poem genre itself which regularly uses extended modes of time and space, multidisciplinary influences, the tradition of the epic, and multiple perspectives. ${ }^{8}$ Brand's use of an extended gaze develops organically from At the Full and Change of the Moon, which explicitly invokes maroonage and diaspora, and A Map to the Door of No Return, 
which also yokes the two experiences together. A Map to the Door of No Return, subtitled Notes to Belonging, is concerned with diaspora and (non)-belonging. The last thirty pages offer a "Ruttier for the Marooned in the Diaspora," a specific type of "long poem" embedded within A Map to the Door of No Return that is based on the oral ruttier form, "a long poem containing navigational instructions which sailors learned by heart and recited from memory" (Map 212). Inventory too is a ruttier, a tool for navigating the onslaught of contemporary global events.

Inventory pursues the exploration of maroonage and diaspora and articulates the tension between complacency and action at the heart of witnessing from a distance. Furthering and extending Gilroy's conception of the Black Atlantic, in Inventory the diasporic subject is part of a planetary community of Caribbean peoples who are linked by their experiences of the Door of No Return and its resulting diasporas and legacies of racial oppression. Brand's work in Inventory in fact looks beyond the poet's typical landscapes of the Caribbean and Canada: here the speaker engages with other colonialisms, other invasions, other examples of war and racially motivated atrocity in a manner that exemplifies a phenomenon that Michael Rothberg calls multidirectional memory. From a vantage point far from the action, Inventory's speaker models the distanced, critical engagement of the diasporic maroon witness and contributes a literary response to the Iraq Body Count Project. ${ }^{9}$ Moved by a sense of accountability and culpability as well as solidarity with the victims of yet another US-led invasion, the speaker watches the news and inventories the wounded and the dead from her Toronto living room. Although dependent on a mediated perspective filtered and edited by western media agencies, she engages in a vigil- a respectful practice of engagement that 
is charged with intensity, albeit not physically active. By recording the events in Inventory's "bristling list" (100), she struggles to honour the victims of the Iraq War:

but never mind that, here is the latest watchful hour -twenty-seven in Hillah, three in fighting in Amariya, two by roadside bombing, Adhaim, five by mortars in Afar, in firefight in Samarra two, two in collision near Khallis, council member in Kirkuk, one near medical complex, two in Talafar, five by suicide bomb in Kirkuk, five by suicide in Shorgat, one in attack on police chief, Buhurz, five by car bomb in Baquba, policeman in Mosul, two by car bomb, Madaen, five by mortars in Talafar, Sufi follower near Baghdad, twelve by suicide bomb in restaurant, bystander in Dora, in Mishada, in Hillah, twenty-seven again, twenty-seven-. (23)

The speaker of the poem is outraged, and she records and lists the civilian deaths of the war in her own Body Count project. While Lousley suggests that the poem's speaker is "anonymous and depersonalized" just like the civilian deaths she meticulously records (45), I contend that the speaker's attention to the civilian deaths in Iraq is motivated, in part, by solidarity and rage for racial injustice: "Nothing personal is recorded here, / you must know that," she admits in Inventory's second section, "but one year the viciousness got to be too much" (22). The speaker feels a solidarity with the victims that is inspired 
by her own diasporic subjectivity. Her sense of herself as a perpetual maroon, exile, and wanderer contributes to her outrage. While the poem's speaker must be demarcated as a fictional construct, these connections to Brand and her poetics of maroonage are productive.

My treatment of the poem depends on my reading of the speaker of Inventory as a descendant of the African diaspora. The poem narrates that she is not entirely surprised when, on a trip to Egypt, she is hailed as cousin by a silversmith in the market: "a voice called to me, "Welcome back, Cousin" (Inventory 56). The speaker describes the voice as "familiar like the sound of water, / rain on a roof or the sea outside a door" (56). With that acknowledgement of familiarity she accepts his intervention not as idle market chatter but as prophecy. The silversmith alludes to the impact of diaspora for the farflung descendants of the Door of No Return: "Welcome, Cousin, it's been a long time, / we have a lot to talk about, / you could be a spy from Upper Egypt / come back alone tomorrow, / we have a lot to say to each other" (56). If the speaker is indeed Caribbean and a descendant of African slaves, she likely has no knowledge of her people before they were taken through the Door, and thus she could indeed have Nubian or Upper Egyptian ancestry. ${ }^{10}$ She agrees with the possibility: "and yes, he could have been my cousin, / and was" (56). The speaker's capacity to accept connections and to understand the consequences of history, as well as to make multi-racial and inter-ethnic alliances, enables her, I would argue, to feel solidarity for the citizens of Iraq whose war experience she watches on the news.

Without claiming identification, she nevertheless feels the need to respond to an injustice committed in part because of racism and cultural intolerance: "the Arab faces 
were Arab faces after all" (22) she notes, revealing her awareness of the racism at play in the American invasion of Iraq. Motivated by neo-imperialist economic power, the War in Iraq is a contemporary incarnation of the triangular trade and the imperialist domination that brought about the Slave Trade. Perpetually self-critical, however, Inventory's speaker understands the irony in the position she now occupies as a citizen of the neoimperialist West, whether or not she is visiting Egypt as a tourist or watching the western-filtered news of the Gulf from her Toronto television. Because of her history as a survivor of slavery she is able to see the vast reaches of implication: "let's at least admit we mean each other / harm, / we intend to do damage" (42). Her motivation to pay homage to the wounded and dying in Iraq, her motivation to carry on "this vigil for broken things" (42), comes from her commitment to social justice and anti-racist practice. This commitment is evocative and exemplary of her vision as a diasporic maroon artist who is conscious of history and its legacy.

Yet it would be unreasonable not to question why Inventory's speaker is so moved by western-biased and edited television news footage, or not to question the legitimacy of her living-room vigil's response to the war. Vellino notes that Brand's speaker is paradoxically marked by both her affinity with diasporic locations and artists and with the 'distanced-observer-witness' from the Global North who is constructed by the ubiquitous circulation of media images of mass suffering (Goldberg 153). The twenty-first century witness who is familiar with the ethics of atrocity representation and consumption debates will recognize the inevitable paradoxes of Brand's weeping witness no matter how vigilant, how critical. (246) 
These "inevitable paradoxes" are in part tempered by the speaker's skeptical attitude in Inventory: she is aware and critical of the media she watches so carefully. The poem opens with a reflection on the influence of television in shaping history and memory: "We believed in nothing," admits the speaker, then writes that she and her peers were influenced deeply by the media of their youth: "the black-and-white american movies / buried themselves in our chests, / glacial, liquid, acidic as love" (Inventory 3). By the time she is an adult, violence has infiltrated western life so much that "the news was advertisement for movies, / the movies were the real killings" (22). The speaker understands that terrorism is big business, and that the news agencies, just like the "experts on terror" who are interviewed on news programs, profit from the airing and disseminating of the "wicked knowledge" (44). She is perplexed by the institutional processes involved in training such experts: "where did they learn this, / where you wonder did such men, ruddy with health, / cultivate this wicked knowledge"? She quickly finds the answer: "then you realize they have an office, / a new industry for the stock exchange / and an expense account, an ardour for subterfuge / they're traders, like anybody else these days" (44). The news footage she relies on cannot tell the full story, and her past experience as an activist causes her to doubt the reliability of the news agencies themselves. And yet she struggles to watch, record, and "think instead of what we might do" (34). Lousley writes that the use of inventories and lists is "the gesture towards making a comprehensive recording of fact, while simultaneously marking its impossibility" (37-38). This gesture is typical of the postcolonial long poem, a genre characterized by "narrative discontinuity, autobiographical self-reflexivity, and attention to local particularities" (Lousley 37-38). I share Lousley's sense that Inventory "offers an 
ethics of ambivalence" (38); despite the speaker's awareness that the media representation of the war is biased and incomplete, she nevertheless feels compelled to offer her own, also biased and incomplete, testimony: the poem itself.

Butler wonders about the productive potential of "remaining exposed to [grief's] unbearability and not endeavoring to seek a resolution for grief through violence" ("Violence, Mourning, Politics" 30). In her own testimony to the lives lost in the War in Iraq, the War on Terror, the War in Afghanistan, the Palestinian-Israeli conflict, and 9/11, Butler urges the West to use the unfortunate reality of mass death and public grief as an opportunity for reckoning. The reckoning impulse is shared by Inventory and ZONG!, and writers like Brand and Philip maintain that there is "something to be gained from grieving, from tarrying with grief" (30). So what might this "something" be and what might be its potential? Committing to preventing the renewed violation of human rights is one thing that can come out of grief. And yet what are the challenges and limitations of taking as subject-matter experiences of human rights violations - how can an artist not do further damage, not "do further violence to these humans, their loved ones, or their descendants by spectacularizing, eroticizing, or otherwise getting wrong the representation of pain inflicted in a grave violation of human rights?" (Goldberg, Beyond Terror 22). The paradox at the heart of politically-engaged art can be summed up with Goldberg's question: "How to create cultural images that will not perpetuate cycles of violence and revenge?" (22). For the poets Philip and Brand, one method is fragmentation, and another, based on humility and ethical listening, calls for an engaged witnessing characterized by stepping aside. 
This vexed relationship between representation of death and atrocity and the fear of complicity is the crux of Wendy Hesford's interrogation of the human rights paradox across various genres, including literature and cultural studies, and its consequences for society and culture. She writes that "acts of representation risk complicity in the violence they depict, endangering both those representing and those represented" (Dawes qtd. in Hesford 190). Hesford concisely summarizes Human Rights scholars' suggestions for how to engage critically without perpetuating injustices:

Others have called for ethical visions predicated on constructs of critical distance, self-estrangement, and heteropathic identification (Silverman 1996); empathic unsettlement (LaCapra 2001); ethical spectatorship (Kozol n.d.); moral spectatorship (Cartwright 1995); witnessing beyond recognition (Oliver 2001); an ethics of the other (Levinas 1981); and the 'impossibility of full ethical engagement' (Spivak 1995, xxv). (197)

Ultimately Spectacular Rhetorics does not abandon the project of representation; instead, Hesford "calls for an ethical rhetorical vision that critically engages the norms and theoretical narratives that characterize the transnational human rights imaginary, particularly as these norms and narratives shape processes of cultural and legal recognition" (190). Hesford's approach is "based not on philosophical universalism but on an awareness of the historical contingencies and rhetorical exigencies of ethical responsibility in its entanglement with institutional structures and individual lives" (190). Within the transnational imaginary, and within diasporic societies, paying attention to death, injury, and grief as Brand does can enable a maroon diasporic witness to 
recuperate the submerged voices of others, and create an opportunity to express outrage and anger, even from a distance.

\section{Oppositional Elegy and Poetic Maroon Witnessing}

In contrast to Philip's ZONG!, Brand engages in a quieter act of mourning in Inventory - the long poem itself is a vigil, a sustained memorial to those lost and still being lost in war, with the narrator and speaker as the principal mourner. There is a further level of embedded mourning within the poem: enclosed in Inventory is an elegiac poem $^{11}$ dedicated to Brand's activist friend Marlene Greene, whose life and death profoundly affected a generation of social activists and political artists. Brand and Greene participated in, witnessed, and survived the revolutionary coup and the US-led invasion of the Caribbean island of Grenada in October 1983. Described or alluded to in several of her texts, including A Map to the Door of No Return and No Language is Neutral, Brand's eye-witness experience of revolution, uprising, and imperialist invasion influences Inventory's response to the events in the Gulf.

In A Map to the Door of No Return, Brand offers an extended reflection and meditation on what she experienced in Grenada. The text reveals the emotional impact that Brand felt when she first found herself in a war-zone, came close to death, and lost her comrades. Here she gives first-person testimony to the massacre she witnessed from her position of relative safety on the balcony of Marlene's house in the Grenadian capital:

I heard the sound of gunfire. It was staccato but guttural. The crowd where I had been standing began running in all directions. I saw people leap from the cliff and bump raggedly down its side. There was nowhere to run. People threw their 
bodies down the cliff trying to get away. I could not hold the glass, the water spilling was like hard stones. I did not feel as if I was in my body. They looked like rags of cloth spilling over the cliff, tumbling. Some looked as if they expected to walk on air. The air dropped from my own body, there were a thousand bright stab wounds in my skin. (165)

Resonant of the "atomic openings in my chest / to hold the wounded" that the speaker suffers from in Inventory (100), in A Map to the Door of No Return Brand corporeally registers the conflict and the physical identification she feels with the victims: "What happens if you stand in a moment like this? Your own body must die, too, I suppose. Even if you do not know. Aren't we all implicated in each other? In any moment like this we must die, too. I was that body draping the cliff' (Map 166). The poet alludes to the never-ending, ongoing aftermath of the trauma: "I left myself on the cliff and I stood on the balcony with Marlene spilling a glass of water forever" (166). Indeed, Brand admits in No Language is Neutral, "Nothing of Egypt," and A Map to the Door of No Return that she went "crazy" after Grenada and "had trouble with life" (156).

Inventory interrogates the tensions between empathy, complacency, and activism, and, I argue, proposes that another form of ethical participation might be seething, engaged critique from a distance. The poem's speaker, like Brand, is a former activist, who cut her teeth on organizing actions, "running to the corner with pamphlets" (Inventory 75), and even travelling to Grenada to bring about a socialist revolution. Now, however, she experiences near paralysis as she sits, riveted, in front of her television. It is my contention that the speaker's stance in Inventory is in fact a posture of strength and engagement, a type of maroon witness that is an appropriate option for ethical 
engagement after experiences of activist burnout and PTSD. With her engaged vigil and critical testimony, Inventory's speaker models a stance of non-frontline ethical maroon witnessing. Here, then, the maroon witness exemplifies distanced dissent, and poetry allows for the articulation of the tension between critical attentiveness and activism.

The post-traumatic impact motivates Inventory in its entirety: Brand's experience in Grenada haunts the poem just as it haunts many of her other works, and the speaker's television vigil mirrors Brand's position on the balcony as she watches the horror unfold below. Nevertheless, the concrete references in Inventory to Grenada are limited to two allusions to Marlene, Brand's beloved comrade from the revolution. Sequence VII, Inventory's meditation on happiness, refers to Marlene, alive and healthy, as one feature on the list of happiness: "coastlines in general, especially from the ferry / between Vancouver and Galiano, one woman / Marlene, living, her hand pulling the strands of hair / at her temple, unraveling all the political / questions" (98). The impact of the word "living," offset by two commas, underscores Brand's ongoing grief for the loss of her friend and co-survivor of the events in Grenada.

Inventory also includes a moving tribute and elegy to Marlene following her death from cancer. In the third poem within sequence IV, the poet reflects on her grief, admits her desperation to have news from Marlene after death, and remarks on the powerful energy that her friend inspired in the activist community. The speaker attempts to describe the impact of Marlene's death: "The day you left the air broke / into splinters" (61). As is characteristic of the pastoral elegy, she wishes she could invoke the natural world to mourn for Marlene with grand gestures of grief: "We should gather rivers for you, / the Layou, the Niger, the St. Lawrence / should weep now, [...] this city should 
spring hibiscus / in late winter when your name / is said" (61), but ultimately the traditional resources of the pastoral are not quite available to her. Marlene's influence on Brand and her activist community was profound, and the elegy's inclusion within Inventory confirms that Marlene's passion resonates throughout the long poem. The speaker writes of her desire to accompany Marlene along her journey through death: "We should carry you / to that country you dreamed / for us" (62). I read this line as revelatory of the author's vexed but ongoing commitment to hope. Just as Inventory concludes with a meditation on happiness, Marlene's dreams of a different world continue to shape Brand's work and in part motivate the vigil of Inventory, its plea to prevent any more "broken things" (42), and its struggle to engage in ethical remembrance. Oppositional elegy is thus one example of the mode of maroon witnessing. Vellino expands on Brand's use of an oppositional elegy towards a "stance of oppositional mourning in the service of political critique and ethical reclamation" (254). The speaker in Inventory watches the news footage like any viewer might, but she takes up the stance of oppositional elegy and distanced, maroon witness. Vellino reads Inventory as "an elegant spillage of public mourning" and thus "links it with other significant anti-elegies of the twentieth century" (254-255). ${ }^{12}$ The phrase "elegant spillage" expresses, I think, the heightened emotional experience that the witness-speaker endures.

Emmanuel Levinas uses the verb "explodes" to describe how the "lesson of truth," the transfer of knowledge, passes from "one consciousness" to "the other" by often aggressive, uncomfortable means. In the case of Inventory, the truth explodes between the victims of the War in Iraq and the speaker of the poem through the medium of the television news footage. Vellino writes that Brand's use of synesthesia in Sequence 
III "[translates] the visual into an aural and implicitly poetic mode of witness" (247). ${ }^{13}$ Here the speaker "hears what is never shown" (Inventory 28) and "listens, each hour, each night / behind the flat screen and the news anchor" (29). On the last page of Inventory the speaker admits that "there are atomic openings in my chest to hold the wounded" (100). Indeed, the poem makes clear that taking on the task of witnessing involves undergoing a harmful, often violent process, but that this is part of the obligation of witnessing ethically. Paradoxically, whereas the prise de conscience or transfer of knowledge is felt violently, the action of the receiver may not be to respond violently. Brand's speaker instead internalizes what she hears and sees and holds the wounds. The "viciousness" explodes toward her, and she responds.

The evidentiary material and structural skeleton that supports ZONG! comes from a legal archive related to the Middle Passage and the Slave Trade. Similarly Brand's work in Inventory depends on her understanding of the Middle Passage and the Door of No Return. It is because of Brand's preoccupation with the Middle Passage that the speaker's gaze in Inventory is able to extend beyond the limits of the Black Atlantic towards other examples of colonialism, triangular trade, wars, diasporas, and invasions. For Diana Brydon, this expansive mode in Inventory represents Brand's political and philosophical commitment to a "planetary humanism" that "rearticulates local, national, and global citizenship" (999) through the dynamic negotiation in the poem of the visceral and political, local and planetary, intimate and unfamiliar. ${ }^{14}$ Critics generally consider Brand's work to center on three landscapes or "three distinct cultural imaginaries of place" (999) notably the Black Atlantic, Toronto and northern Ontario, and Grenada at the time of the revolution and US invasion. However, Brand's gaze and her notion of 
citizenship already widens in earlier works including What We All Long For and At the Full and Change of the Moon, two novels that deal explicitly with plural diasporas, interdiasporic alliances, and the feeling shared by diasporic subjects of being perpetually marooned between places, always elsewhere and in-between. Indeed I argue that in Inventory it is because of the speaker's experience with the Door of No Return that she is able to feel compassion for others and engage in secondary witnessing.

In the poem, the speaker obsessively watches footage of the first War in Iraq. Her vantage point is inside her home, and she takes on a posture of witnessing from which she can "keep watch at the window / of the television" (Inventory 28). The television screen is a window, a portal, a door onto the world, and it recalls the Door of No Return that is both the mythic and physical opening of the Black Diaspora and what made maroon resistance necessary. In A Map to the Door of No Return, Brand offers several definitions and meditations on the significance of the Door: "the door is a place, real, imaginary and imagined [...] The door out of which Africans were captured, loaded onto ships heading for the New World. It was the door of a million exits multiplied" (Map 19). Brand argues throughout A Map to the Door of No Return that the historical experience of having ancestors pass through that door leads to a perpetual sense of being in-between, of being marooned between a forgotten past and a hostile present: "There is the sense in the mind of not being here or there, of no way out or in [...] Caught between the two we live in the Diaspora, in the sea in between [...] Our inheritance in the Diaspora is to live in this inexplicable space" (20). Across her oeuvre, across disciplines and decades, Brand's writing deals with the consequences of the Door: the African diaspora, slavery, 
and maroonage; her texts promote a diasporic Caribbean planetary citizenship that is oceanic in its scope.

Though Philip in ZONG! is more concerned than Brand is in Inventory with interrogating the use of the English language, elsewhere in her work Brand also engages with these ideas by writing in the demotic (In Another Place, Not Here), and by articulating the limits of language, English or demotic, to express experiences and historic truth (No Language is Neutral, Land to Light On, Thirsty). In What We All Long For her second-generation Canadian characters describe themselves as unwilling translators who constantly have to negotiate between linguistic, cultural, and temporal worlds in order to live in contemporary Canadian society. Brand's examination of language, like Philip's, reflects both her commitment to decolonization as well as her project's solidarity with poetry of extremity and the untranslatability of trauma.

While Brand is self-consciously concerned with the English language throughout her oeuvre, in Inventory her work with breakdown and fragmentation has its most compelling effect in the narrated mental breakdown of the long poem's speaker. One of the consequences to the speaker's preoccupation, indeed obsession, with watching and recording the news is that it triggers the PTSD she developed after Grenada. Since beginning her television vigil, she loses touch with her life as she used to live it: "the butter's gone rancid, / remember that cat we used to have, / it disappeared the first day, / lemons, remember to buy lemons" (Inventory 28). She spends much time and energy living in a parallel life, the one she "listens [to], each hour, each night, / behind the flat screen and the news anchor" (29). She neglects her household obligations, her work, her relationship, and her own health. The horrors that she witnesses during her television 
vigil inspire suicidal thoughts: "the waiting, she can't bear the waiting, / the metal, metal, metal of waiting, / she sits devoted, the paring knife close / to a harvest of veins" (29). As the vigil and the process of witnessing consume her body, she becomes a weeping thing: "all I can offer you now though is my brooding hand, / my sodden eyelashes" (37) and "the / abacus of [my] eyelids" (38); the watching, counting, and recording she has been doing has marked itself fully onto her body. The speaker's process of witnessing has shaken and disturbed her, and she wonders if she is forever changed: "the body keeps thinking it will return / to its vigour, it will receive phone calls / and run to the corner with pamphlets" (75) — but the energy she used to have as a young activist is long gone. In the middle sequences of the poem, the speaker is exhausted by the heavy knowledge and loses the drive to educate, to organize, and to act. Instead, she feels more and more dysfunctional and deranged, and she wonders if she is the only one paying attention to the "ravaged world" (11).

In contrast to the activist work she would have done in the past, she can now only engage in her late night vigil. The speaker's unraveling and her symptoms of PTSD reveal the connection between her and the speaker who mourns the passing of Marlene Greene; when taken together, it is clear that watching the footage of the War in Iraq triggers and re-ignites the trauma endured in Grenada. Indeed, the PTSD symptoms are those of a chronic stress disorder that cannot easily be healed. And yet despite the loss of her energy for action, the speaker retains her impulse to engage and contribute. In Inventory this motivation is distilled into a less physically active but nevertheless engaged stance of diasporic maroon witnessing. Inventory, then, is the speaker's poetic response to the 
injustice she witnesses; it is the offering of a former activist who can no longer organize a protest but who can record a "bristling list" of what she witnesses during a long vigil.

In a moment of typical introspection, as part of another list and litany of deaths, the speaker notes the death of "twenty by / suicide in Baghdad, child on bicycle by bomb / in Baquba" and wonders "why does that alliterate on its own, why / does she observe the budding of that consonant" (38)? She is disturbed by her unconscious ability to see the poetic value in that part of the list, even as she judges herself. In that moment, she wonders just how ethical she is being: is she making a poem, perhaps, out of the misery she is witnessing? Her self-reflection and self-criticism are ongoing in Inventory. Just as the perspective switches, almost seamlessly, from first person to third person, the speaker's hold on herself and on the world is also tentative, perilous, flimsy (28). Indeed, this shift in point-of-view indicates the breakdown and unmooring of her mental health, the triggering of her PTSD, and her experience of secondary-trauma from engaging with this latest war. ${ }^{15}$

The speaker's isolation and breakdown alienate her not only from emotional stability and the people in her life, but also from her society in general. Because she is not indifferent about the war, she feels differently from her compatriots in Toronto, and she is separated from them by a type of internal exile resonant of the maroon experience. The speaker says that "all this became ordinary far from where it happened" (22) and that while "everyone grows perversely accustomed $[\ldots]$ she refuses" (29). She is motivated to continue her late-night vigils precisely because no one else seems to care: "At least someone should stay awake, she thinks, / someone should dream them along the abysmal roads" (26). The speaker finds it tragic that the victims of war do not die only once "over 
there" but that, because of western indifference and its converse spectacularism, they die again "in the secret seas of living rooms here" (39). She feels duty-bound, obligated, and responsible to witness and respect the otherwise "ungrievable" Iraqi deaths (Butler, "Violence, Mourning, Politics" 30). The television is therefore paradoxically the site of the speaker's sensitive vigil and, for other viewers, it is instead the venue for killing by apathy and negligence. Her fellow citizens are indifferent, complacent, and inactive; indeed, they protect themselves from being moved by the suffering of others by "[carrying] umbrellas against the drizzled rain of evidence" (Inventory 40). Like the prophets of classical literature, despite or because of her ravings and insomnia, the speaker is not heard; she is alone at the window, looking out. For Vellino, Brand's speaker is "an Antigone for our times" whose "ceaseless labour" of witnessing otherwise ungrievable bodies (255) is characterized by an "aggrieved dedication" (Spargo 5 qtd. in Vellino 255) and "militant grieving" (Rae 22 qtd. in Vellino 255). Unlike the characters in At the Full and Change of the Moon who are linked in a network of family and lineage, Inventory's speaker, like Antigone, is isolated, lonely, and bereft.

Brand's project in Inventory attempts to tease out a stance of ethical witnessing regardless of action or impact. The speaker's self reflexivity and awareness of her own struggles indicates that she is aware of the human rights paradox at work and the underlying threat that she is complicit in re-injuring the wounded through voyeurism. ${ }^{16}$ Yet she cannot stop watching the news and inventorying the deaths, because she knows at least she is doing something. As Wendy Hesford argues, holding onto hope is necessary for activists and scholars: "Images of human rights violations run risks, can be commodified, and do not, in and of themselves, generate social change. Yet spectacular 
representations are pervasive, if not always persuasive, sites of cultural and political engagement that keep the human rights agenda in the public eye" (201-202). Hesford writes that engaging in the human rights paradox also involves admitting to its ambiguity:

This is a call for ethical visions that focus on how human rights law and culture are mutually implicated in, and set the parameters for, social and political recognition and identification practices [...] Visions that extend the ethical parameters of our engagement with distant others by infusing human rights advocacy with a social imaginary predicated on an engagement with the contingencies that compel the pursuit of justice. (197)

With Inventory, Brand too engages in the promotion of a type of ethical engagement "with distant others" (197). Even in her non-physical activism she is a self-critical and generous witness, open and vulnerable to what she sees. In the case of Inventory's mediated secondary witness, the process of watching the atrocities of the war goes hand in hand with the process of recording the events: "she has to keep watch at the window / of the television, she hears what is never shown, / the details are triumphant, / she'll never be able to write them in time" (Inventory 28). Here the work of the witness conflicts with "what is never shown" in the official archive. The importance of responding to the human rights injury is key, and it is via that response that witnessing can inspire a socially transformative response, and perhaps end to war and trauma.

\author{
$* * *$ \\ Inventory's seventh and final sequence begins with the speaker's typical self- \\ derision and irony: "On reading this someone will say / God, is there no happiness then"
}


(89)? "Of course," she answers, almost laughing, and then she begins a different kind of litany, an inventory that captures the moments of happiness and joy she sees in the world: "of course, tennis matches and soccer games, / and river song and bird song and / wine naturally and some Sundays / [...] sunlight on any given day / anywhere, however disastrous at least magnificent" (89). The sequence on happiness suggests that the speaker has not succumbed entirely to her experience of PTSD and, though her energy might be limited and her skepticism high, she is still moved by beauty, just as the maroon figure's stubborn resistance is motivated by elusive freedom. This conclusion to the poem highlights the resilience and beauty of the natural world, the surprising uniqueness of people, the wonder of rain and water, and the magic of music and dance. To this image collection I would also add the recurrence of the "doorway." There are many doorways, doors, and windows throughout Brand's oeuvre, most notably the omnipresent Door of No Return, and I would like to suggest with this thematic return to the Door that, like music and water, doorways offer destructive but also generative possibilities.

As discussed previously, the doorways in Inventory are vantage points for witnessing: they can be the windows of a slave-castle that look out onto the vast Atlantic Ocean of the Middle Passage, windows overlooking the streets of Baghdad, or windows that open onto a hoped-for, different world, "that country [Marlene] dreamed / for us" (62). The long-poem Inventory is one such doorway, or portal, from which to look through and be inspired to take positive, compassionate action. Inventory is itself both a testimony and a summons for action. Unlike the monuments to war, victory, and conquest that the poem's speaker visits in Italy and Egypt, “monuments that survive / everywhere, in essence signs of the most brutal / among us [...] the result / [...] [of] some small- 
mindedness" (69), Inventory itself is a type of imaginative "counter-monument" (Young) that obliges the reader to stand on a threshold and contemplate the past before stepping forward. The long poem asks the reader to take into consideration past "smallmindedness," past ravages, and to imagine a world where people no longer "intend to do damage," a world in which the speaker "may stop this vigil for broken things" (42). The speaker says she has "nothing soothing to tell," nothing to offer except for "this bristling list" (100), but despite her skepticism she also inspires the reader, like both Marlene Green and Kamena, to keep searching for a safe haven, a maroonage.

I read Inventory as the speaker's testimony to her work of witnessing: "Stay now, she's written a letter, / an account of her silence, / its destination all the streets / beginning with Al Kifah, Al Rashid ...” (34). The speaker recognizes her lack of concrete activist action (34), and yet her witnessing is not passive. In describing the letter, she interrupts herself by directly interrogating the reader: "what door are you looking through now, / still what door are you looking through, / what sound does the world make there, / the sound you must have heard / before these disasters, the sound / you must keep" (34). This passage is a synecdoche, a microcosm or miniature of Brand's project in Inventory, and the imperative command "you must keep" draws us in. The speaker challenges the reader to protect "the sound" of the world "before these disasters." On the next page, she demands comparable action of the reader: "if I say in this letter, I'm waiting / to step into another life, / will you come then and find me" (35)? The practice of ethical remembrance, the dream of a better world that is a safe maroonage, is a task that must be taken up by the reader. ${ }^{17}$ Inventory is a guide, a ruttier, for ongoing ethical navigation. In 
the form of the oppositional and elegiac long poem, in the quieter yet still "bristling" activism of literature, Inventory presents a model for ethical witness.

Yet do the experimental poetics of $Z O N G$ ! and the complex witness stance of Inventory potentially limit the impact of the authors' resistance projects? Is Philip, in $Z O N G !$, not perhaps overly devoted to exploding the limited archival material she works with? Similarly, does Brand's poetic vigil in Inventory contribute any positive change? Are both Brand and Philip more concerned with the form and witness stances of their work than in engendering any productive human rights action and if so, have they sacrificed politics for poetics? Philip's intention is to "let [the voices of the Zong] offer themselves up" in order for her to respectfully commemorate them. The scraps of the author's own letters and journal entries included in "Notanda" reveal that the poet seems overtaken by her own experiment and genuinely feels as if she has given herself up to the text. Although Philip's opaque writing supposedly frees the lost voices, does it instead further obscure and perpetuate the ongoing un-grievability of the Zong's victims? Can Philip in fact be accused of spectacularizing the event through her linguistic and poetic experiments? Turning to Brand, is the speaker's stance in Inventory enough? More provocatively, is Brand guilty in Inventory of reiterating the cliché of the privileged North American television viewer who passively watches atrocities on his or her television set and thinks they are informed about the Global South? The speaker's nervous breakdown might be read as the representation of Western guilt that further exoticizes war, as her guilt and consumption of suffering is turned inwards.

Ultimately the ambivalence of Philip's and Brand's postures of witnessing reflects the opacité or complexity of the very events they witness. Ratcliffe's approach of 
"standing under" (28) offers a useful theoretical frame or perspective. In ZONG! and Inventory the poets step back from the action; whereas the speaker of Inventory admits her inability to join in active protest, the speaker in ZONG! mutes her contemporary voice in order to "let them speak for themselves" (Dorfman qtd. in Against Forgetting 37). The vigil of Inventory and the frenzied wake in ZONG! coupled with the writers' challenging poetics of extension and fragmentation reveal and express a philosophical commitment to stand under, to stand aside, and to let the testifying voices of history and indeed the injured bodies of the victims come through as clearly as possible. In the poems, the writers' maroon resistance rings out in the use of linguistic and poetic fragmentation, in the structure of the performative wake and the oppositional elegiac vigil, and in the use of polyphonic narrators and self-aware speakers. Paradoxically, what is most revolutionary is the writers' understanding that in order to ethically honour the dead, to stand in solidarity with those voices and bodies, they must poetically stand under, from a distance.

\footnotetext{
Notes

${ }^{1}$ Other fictional writers who refer to the Zong and to the fate of its passengers include Michelle Cliff, David Dabydeen, Maryse Condé, Toni Morrison, and Fred D'Aguiar. In Specters of the Atlantic Ian Baucom notes that writers continue to bear witness to the atrocity on the Zong and in so doing point to an "order of historical time" that "accumulate[s]" (305).

${ }^{2}$ At the time of the writing of this dissertation, M. NourbeSe Philip herself has been presenting collaborative performances and group readings of ZONG!. These performative, theatrical, and musical experiences provide opportunities for readers and audience members to access the embodied cacophony, vibrant energy, and passionate grief I try to describe in this chapter. For more about these performances, please see Joseph LaBine's blog entry "Review of an October Performance of M. NourbeSe Philip's 'Zong!"' (8 April 2014) found at http://flatsinglespress.blogspot.ca and this video of a performance at the University of Windsor: http://www.youtube.com/watch?v=wCjkuqi_mds\&feature=youtu.be

${ }^{3}$ What is known as the "spectral turn" in criticism has been explored by Jeffrey Andrew Weinstock in Spectral America: Phantoms and the National Imagination and in The Spectralities Reader: Ghosts and Haunting in Contemporary Cultural Theory edited by Maria del Pilar Blanco and Esther Peereen.
} 
${ }^{4}$ Throughout Africa and the African Diaspora, the water spirit Mami Wata or Yemaya (Mother Water) is revered for her paradoxical benevolent protection and her ability to be vengeful and violent. Often portrayed as a snake charmer or as a mermaid, Mami Wata's physicalization represents the fusion of ancient indigenous African mythologies and European religious icons and figures introduced at the time of exploration, contact, and colonialism. Interestingly, Mami Wata is rendered in the Haitian Vodou pantheon as La Sirèn (the mermaid); in The Loneliness of Angels Elsie dreams of a black mermaid who beckons for her to leave Ireland for Haiti. Centuries later, Catherine has the same vision when she returns to Haiti.

${ }^{5}$ One of Danticat's narrators, certain he will be drowned with his fellow refugees, tries to accept his fate: "I go to them now as though it was always meant to be, as though the very day that my mother birthed me, she had chosen me to live life eternal, among the children of the deep blue sea, those who have escaped the chains of slavery to form a world beneath the heavens and the blood-drenched earth where you live" (27).

${ }^{6}$ My sense of the counter-monument is informed by James E. Young's model of the counter-monument in At Memory's Edge.

${ }^{7}$ Here Forché embeds a reference to Paul Celan, who described the German language as having "passed through the thousand darknesses of deathbringing speech" ("Speech at Bremen" 395).

${ }^{8}$ See Cheryl Lousley's "Witness to the Body Count" in Canadian Poetry for a comprehensive study of Inventory's poetics and its relation to the long-poem form as well as to eco-criticism and postcolonial criticism.

${ }^{9}$ Credited in Brand's acknowledgments to Inventory, the Iraq Body Count Project is a "nongovernmental watchdog project on the US-led war and military occupation. The group's mandate emphasizes its role as an ethical supplement to global geopolitics: US General Tommy Franks's statement 'We don't do body counts' is quoted prominently on their website to show that this NGO effort is required because the US government refuses to document civilian death (Iraq Body Count)" (Lousley 42-43).

${ }^{10}$ As Brand says of her own family, and as I discuss in more detail in Chapter Four, "we were not from the place where we lived and we could not remember where we were from or who we were" (Map 5).

${ }^{11}$ The Elegy or Elegiac Poem in the English tradition can be defined broadly and specifically. In the general sense, it is "a poem of melancholy reflection upon life's transience or its sorrows" and in prose it is a "work dealing with a vanished way of life or with the passing of youth" (Oxford Dictionary of Literary Terms 105). The Routledge Dictionary of Literary Terms defines Elegy broadly as an "archetypal general meditation on the passing of life, unconnected with any particular death" (67); for Coleridge the elegy is "the form of poetry natural to the reflective mind" (67-68) and thus it is often associated with a morose mood or solemn style, with melancholic poems about life and mortality, and with poems in honour of a particular person.

${ }^{12}$ Vellino highlights the "oppositional elegies" of Wilfred Owen, Langston Hughes, and Sylvia Plath.

${ }^{13}$ Vellino writes that Brand's use of synesthesia demonstrates an attempt "to move beyond the positions of the apathetic and/or sentimental weeping spectator (Lousley 52) by disrupting the rhetoric of visibility that operates paradoxically in both state security and human rights discourses (Hesford 3, 7)" (Vellino 247).

${ }^{14}$ Writes Brydon: “in Brand's work such a re-visioned humanism in relation to planetary space involves a reimagined citizenship, as a mode of belonging and acting in the world" (1000).

${ }^{15}$ Roger Simon writes that the experience of secondary trauma can impact across a spectrum of immediacy and connection: "this return of the past - this traumatization - is experienced not just by the primary witness (the survivor or eyewitness), but can occur for those who hear or read accounts of what others have experienced" (51). 
${ }^{16}$ Vellino's article indicates how Brand's speaker admits complicity several times in the long poem, especially in the consumption habits of the Global North: "the forests we destroyed, as far as / Amazonia's forehead, the Congo's gut [...] we did all this and more" (7).

${ }^{17}$ The poem exemplifies Forché's contention that the poem of atrocity "calls upon the reader, who is the other of this work, to be in turn marked by what such language makes present before her, what it holds open and begets in the reader, for witness begets witness" ("Living Archives" 137). 


\section{Chapter Two}

\section{Vodou Novels as Alternatives to the Postcolonial Gothic in Chair piment by Gisèle Pineau and The Loneliness of Angels by Myriam Chancy}

This chapter focuses on the critical possibilities available when Caribbean literature is interpreted according to locally-specific frameworks rather than imported European categories. I turn to literary examples that emphasize the need to integrate local spirituality into scholarly criticism in order to approach Caribbean literature from within its own cultural framework. To do so, I engage with a cross-cultural concept of vodou that demonstrates a world view shared by the various "diasporan religions" (Murphy) that developed out of the interactions between indigenous African religions, indigenous Amerindian religions, and Christian European religions. Throughout this chapter, I will use the term "vodou" to describe the practices of these diasporan religions in general, and "Vodou" will be used to describe Haitian Vodou in particular. Overall, by reading for spirituality, corporeality, and the dignity of human life in Caribbean literature, postcolonial literary criticism can integrate human rights concerns into its understanding of trauma and resilience.

This chapter will focus on the contribution of vodou as an analytical framework and critical lens that can be seen as an alternative to the popular "Postcolonial Gothic" genre. Unlike the Postcolonial Gothic, vodou is not an imported framework to describe Caribbean literature; in fact, like the critical concept of maroonage, vodou's origins are simultaneously indigenous and diasporic, and thus it is emblematic of the syncretic literature of the region. In this chapter I consider two novels in which vodou spirituality offers empowering possibilities: Gisèle Pineau's Chair piment (2002) and Myriam Chancy's The Loneliness of Angels (2010). My critical attention to the presence of vodou 
highlights its thematic and formal value as a resistance strategy against disenfranchisement in the diaspora and against the psychological impact of slavery.

Contemporary literary texts of the Francophone and Anglophone traditions reveal the connection between religion and decolonization strategies such as historical maroonage and inter-ethnic solidarity. Considering vodou as a framing device for literary interpretation emphasizes key strategies of resistance shared by the vodouisant and by the diasporic maroon witness including a commitment to alliance building, syncretism, multidirectional memory, connectivity, and spirituality. Moreover attention to vodou as a world view that is shared across former colonial boundaries is invaluable for forging relations between the diaspora and the Caribbean as well as strengthening interCaribbean archipelago solidarities in a region still fractured by colonially-imposed divisions. For these reasons, I read literary representations of vodou as reflective of a distinctly Caribbean, even indigenously Caribbean, system of religion and cultural resistance. What kind of healing might vodou culture provide for a diasporic subject experiencing dislocation and disenfranchisement? Because vodou developed out of the interaction between the fact of slavery and the cultural clash unleashed by colonialism, in other words the meeting between diasporic and indigenous cultures, it is therefore two things at once, dynamic, and dialectical. Seen in this way, vodou is a productive lens through which to read diasporic Caribbean literature, since it reveals the tensions that come from articulating, in James Clifford's words, "both roots and routes" (308), a blending together that results in the diasporic subject's inherently paradoxical experience of "[living] loss and hope as a defining tension" (312). 
Not limited to Haiti or to Haitians, the culture and religion commonly known as vodou is observed, albeit under different names, throughout the Caribbean region and in Caribbean spaces such as the Louisiana Bayou (where it is called Voodou), Haiti (Vodou), Cuba (Santería), Jamaica (Obeah), and the North East of Brazil (Candomble). In Guadeloupe and Martinique, vodou practices are called Granbois, quimbois, or sorcellerie and fall under the category of a general spiritual culture practiced especially in the rural countryside but also, strikingly, in the largely urban diasporic communities of Hexagonal France and Montreal. In Haiti, the cultural and religious practices of Vodou do not necessarily conflict with Catholicism or other religions such as Judaism, Hinduism, or Islam, as will be shown in my discussion of The Loneliness of Angels. In Martinique and Guadeloupe, it is common to consult a gadèzafè or quimboiseur (healer) or a devineresse (seer) in conjunction with consulting Christian cultural leaders, just as it is common in Haiti to recite Vodou prayers along with "Our Fathers" and "Hail Marys."

Indeed, vodou's resilience and survival over the centuries can be seen partly as a result of its ability to integrate other religions, including the indigenous religions of the Caribbean region. Historically, indigenous communities transmitted to the early vodouisants and maroons the knowledge of local spirits and medicinal herbs. Vodou played a role in surviving slavery and the colonial plantation system's dehumanization industry, and it helped to inspire the physical struggle for freedom. ${ }^{1}$ Perhaps the need for the religion could have disappeared with the emancipation of the slaves, the end of the slave trade, or even the independence of Haiti; instead, Haitian Vodou and its sister religions continue to be practiced today, despite ongoing attempts at suppression. ${ }^{2}$ I argue that taking up vodou as a literary frame and reading Caribbean literature according to a 
voudoist world view or "culture vodou" offers a productive critical opportunity to read Caribbean literature from a decolonizing perspective as well as a human rights framework that emphasizes the connection between spirituality and restoring human dignity.

One common characteristic of Caribbean literature both from the archipelago and the diaspora is a focus on the spiritual world of the region, as well as a common gaze towards the past, even to the spirits of the dead. In western literary studies, this "spectral turn" to the ghosts and haunted-ness of the past, evidenced in contemporary literature as well as criticism, is often associated with the genres of the postcolonial gothic and magical realism. Cynthia Sugars and Gerry Turcotte write that "in many instances, the postcolonial Gothic involves a transposition of conventional gothic and colonialist metaphors, turning gothic conventions on their head by converting the unfamiliar or ghostly into nonthreatening — even sustaining — objects of desire" (xi). Alison Rudd defines a particular "Caribbean Gothic" sub-genre that is marked by the use of figures such as the ghost, zombie, soucouyant, and duppy to represent the psychological condition of colonized peoples as well as the legacies of gender and racial inequality (22). She explores "schizophrenic splitting and/or doubling" as it is manifested especially in "the ambiguous, polymorphous figure of the duppy" (31). For Rudd, the representations of schizophrenia and doubling in the texts reflect the "temporal disconnection" (64) caused by "the horrors of Caribbean history and the anxieties that continue following decolonization" (65). The author sees a characteristic disconnection and hauntedness in the writing that "articulate[s] a sense of alienation and displacement from the past and hence within the present" for both diasporic and archipelago writers 
(33), an alienation that is also shared by the diasporic maroon witness.

Yet this attention to spirituality and spirits does not make Caribbean literature inevitably "gothic." In fact, what is occluded when these terms are yoked to the literature of the Caribbean? Like scholarly approaches to psychoanalysis and trauma theory, these terms struggle to adequately describe the literature of a society in which spirits and spirituality, as well as magic, are part of the world view and of "normal" life. The category of gothic has colonial connotations as a contrast to a European sense of "normalcy," and hence it invokes a desire for containment and civilization when applied to the Caribbean. In many ways "the Caribbean learned to 'read' itself in literature through Gothic fiction" first "as the backdrop to terror $[\ldots]$ as the site of the mysterious and uncanny, or in histories that underscored the violent process that led to its colonization" (Paravasini-Gebert 233). Even when local Caribbean literature began to emerge in a sustained way, "Caribbean fictions - often through parody - mirrored the devices and generic conventions of their European models" (233). In contrast, vodou as an analytical framework allows for the co-mingling of the spirit world with the human world and the past with the present without rendering it "gothic" and therefore associated with all of traditional European gothic literature's emphasis on the containment of disease, containment of excess, and racist ideologies. ${ }^{3}$

Related to the genre of the gothic is a subgenre that Erica Johnson calls "Caribbean Ghostwriting." Johnson identifies ghostwriting as related to historical fiction, with the caveat that ghostwriting involves fictionalizing "the fragments of an individual life" (14) in order to "[tell] subaltern biographies in particular" (15). She argues that the subgenre is an authorial "response to the problems of colonial historiography and archival 
erasure" (13) and that it therefore involves a recuperation of lost histories and stories through a process of "literary archeology" (Toni Morrison in Johnson 18). Chair piment and The Loneliness of Angels are also interested in recuperation, but although they contain ghosts and attempt to reveal and recuperate lost stories, especially repressed stories of miscegenation and incest, the novels do not fictionalize a lost historical biography or give life to an erased name or particular historical person. However, they do engage with collective history and family history in order to contribute to the postcolonial and feminist project of recuperating lost narratives, highlighting the gaps in normative history, and resisting "persistent erasure" (14). Although not Caribbean "ghostwriting" per se, the novels do engage in a "stance of resistance against dominant historical narrative" (Cudjoe in Johnson 15) and the larger Caribbean literary project of "reconstructing counterdiscursive histories" (Johnson 15).

In vodou spirituality there is no line between the human and the spirit world, yet European models of Christianity and psychology problematize the blurring of these worlds. Perhaps not surprisingly, mental illness is over-represented in Caribbean literature from various eras including Wide Sargasso Sea by Jean Rhys, Cereus Blooms at Night by Shani Mootoo, Dreaming in Cuban by Cristina Garcia, Breath Eyes Memory by Edwidge Danticat, Pluie et vent sur Telumée Miracle by Simone Schwartz-Bart, L'esperance macadam by Pineau, Amour, colère, folie by Marie Vieux-Chauvet, C'est vole que je vole by Nicole Cage-Florentiny, and Michèle Lacrosil's Cajou. Most significantly, mental illness is a common condition for women characters, who are often diagnosed as mentally unstable if they have spiritual experiences. In the texts listed above, mental instability is presented alternately as madness or insanity; as a violent 
consequence of the legacy of colonialism; as mental withdrawal or dissociation; as a coping mechanism for trauma; or as a visionary gift but mental burden.

This chapter emphasizes the origin of mental and physical violence within the slave trade itself, in the New World plantation, and in the legacy of colonialism. I am interested in tracing the psychiatric impact of slavery and the recuperation of vodou as a strategy for restoring spirituality and human dignity in the literature of the region. In this chapter, two contemporary texts from the Francophone Caribbean demonstrate the inherited trauma of slavery and its nefarious choke-hold on the multiple generations of two families. The presence of spirituality in the texts reveals the importance of vodou as a productive formal and analytical category that, like literary maroonage, is also suggestive of resilience, liberty, and healing. The unusual female characters in Chair piment and The Loneliness of Angels are marginalized outsiders in their diasporic societies; importantly, however, they come to rely on a spirituality that is manifested through a supernatural connection to their ancestors and to the natural world.

My investment in the scholarly investigation of spirituality in Caribbean literature has a deep connection to the questions of secularism and post-secularism that currently preoccupy contemporary critical theory and that deserve a much more robust engagement than what I can propose in this chapter. ${ }^{4}$ I nevertheless wish to note the relevance of this scholarship and its significance in underlining why it is worthwhile to read for spirituality in Caribbean texts. The opening gambit of the conversation is the conceit that Christian societies involve a separation of Church and State and that the philosophies that emerge from Christian Europe are also secular and therefore more rational, liberal, modernist, enlightened than philosophies developed in societies informed by notions of piety. As 
critics such as Talal Asad and Michael Warner have shown in their work, EuropeanAmerican assumptions about the merits of secular society have both justified the vilification of religious societies, masked the prevalence of Christianity in supposedly secular social institutions in the West, and "naturalized" modernity and secularism in the same breath. Importantly, the novel genre in literature is considered to be "secular" in traditional scholarship because of its supposedly inherent relationship to modernity, which is also considered to be secular. ${ }^{5}$ Ultimately it is limiting to see the secular and secularism as more evolved than religion and spirituality, just as it is dangerous to yoke religion with fanaticism or to disavow rational and modern experiences related to faith and piety. Saba Mahmood's Politics of Piety, for example, studies committed religious activity by Egyptian women who are part of the vibrant $d a^{\prime}$ wa religious movement, and the book proceeds with a feminist methodology and an interest in seeking examples of female agency and resistance. Caribbean vodou culture, as I will show, is characterized by the very "overlapping, fragmented cultures, hybrid selves, continuously dissolving and emerging social states" that Asad suggests become clear when we abandon the idea that the world is divided into distinct binaries (15).

How does this scholarly interest in piety and religion inform or change my reading practice of Caribbean literature? Like Mahmood I am interested in how "political projects are not only the result of coalitional organizing, ideological mobilization, and critical deliberation. They are predicated upon affective, ethical, and sensible capacities that are often ignored as consequential to the analysis of politics" (xiii). Subsequently I propose an investigation into representation of vodou in Caribbean literature that does not rely on gothic or orientalist understandings of non-Western religion and that therefore 
opens up the possibility of reading Vodou as an engaged, emboldening realm of activism, especially for women practitioners. This chapter argues that attention to religion and embodied spirituality, in other words attention to piety, restores the recognition of the spiritual human to the traditionally secular understanding of human rights.

\section{Vodou, Possession, and Zombification in Chair piment}

Gisèle Pineau's Chair piment presents the extent and currency of vodou-like spirituality, culture, and practices both in the French Antilles and in Metropolitan France, where many Martinicans, Guadeloupeans, and French Guyanese have made the landlocked region of Ile-de-France into another Caribbean "island." In Chair piment, set in Guadeloupe as well as in the northern Parisian suburbs, a similar culture of spirituality is shared between the Guadeloupian and Martinican characters. As such I will not differentiate between local practices and instead use "vodou" to refer not only to Haitian Vodou but also to a regional Francophone Antillean vodou that includes Grandbois, quimbois and sorcellerie. This culture of vodou is informed by the region's various syncretic religions and healing practices, "powerful repositories of inner strength and cultural affirmation" that have left "deep imprints on every significant cultural manifestation of the various islands" (Fernández Olmos and Paravasini-Gebert 2). While my combination of diverse practices under the general term vodou might appear reductive, in fact my aim is to open up the category and show the pervasiveness of a regional culture vodou as a simultaneously local and diasporic phenomenon.

While scholarly work in either French or English on Chair piment tends to focus on the experiences of the protagonist Mina Montério, this chapter is also concerned with 
the spiritual life of other characters including Mina's sisters Rosalia and Olga, the supposed family friend Suzon Mignard, and the depressed Frenchman Victor who becomes Mina's partner in her quest for spiritual healing. The characters interact with and seek the advice of spiritual healers: Sarah Pitagor, a Martinican "medium and devineresse" (Pineau 15); Bénédicte, an Antillean woman who is a prophet yet so intently haunted by spirits that she is regularly committed to the psychiatric wards; and Berlus, the gadèzafè or healer of the village of Piment (Guadeloupe) who is powerless to prevent or tame the insatiable dark spirits that Suzon Mignard unleashes against the Montério family. Antillean vodou is at the heart of Mina's quest for personal healing from her diasporic disenfranchisement. Importantly, it also has a connection to Mina's original family trauma, a trauma caused in part by Suzon's onslaught of Black Magic as well as by a much older psychic wound, the trauma of the slave trade.

The novel opens in a dismal apartment complex in the northern Parisian suburbs, with Mina Montério engaging in yet another random and un-emotional sexual encounter. As usual, she is accompanied and observed by the ghost of her sister Rosalia. Always appearing at the moment of orgasm, Rosalia watches over her sister. In ghost form, Rosalia takes the shape she had when she died: burned alive, her hair a crown of flames and her skin charred to a crisp (13). Mina first "sees" Rosalia just after her death in the fire that destroyed their family home in Guadeloupe; while recovering in the care of Suzon Mignard, Mina experiences the first terrifying visitation, during which she sees Suzon's house go up in unquenchable flames. Then she encounters the ghost of her sister: "She was in front of me, her head bent to one side. With her nightgown in flames, her braids in flames ... I cried out. And then I fell to the floor: I must have fainted" (77). ${ }^{6}$ 
Despite Suzon's admonitions and the doctor's prescription of a tranquilizer with which to calm what they considered her "hallucinations," Rosalia continues to appear, even when Mina boards a plane to Paris. Like a loyal dog, she does not leave Mina's side and pursues her to the Paris home of their half-sister Olga and her husband Doug. A few years later, the day Mina and Doug consummate their inappropriate, if not incestuous affair, Rosalia watches them with particular attention. That night, Mina accuses Rosalia of having achieved what she had wanted, and begs her to leave. Mina is finally able to banish Rosalia with a combination of terrible insults, fervent Catholic prayer, and vodou rites:

I don’t want to see you anymore. You are mean! You are a demon! [...] Go away! Go away, Rosalia! Go back to Hell!" implored Mina, gripping the cross she wore on a chain around her neck, "Disappear! Go away! My God! Make her go away! [...] God, save me from these evil spirits, O Lord, keep me from these devils $[\ldots]$ chase away the ghost of my sister! $(84-85)^{7}$

In essence, Mina banishes the ghost of Rosalia by composing a Catholic-like prayer against ghosts and demons, thus demonstrating a syncretic blend of Christianity and vodou.

But Rosalia is not finished yet with Mina, and she returns with a vengeance after Mina lights a cheap candle and says a cursory prayer of remembrance to mark the twentieth anniversary of the fire (15). She appears at the altar "like a summoned spirit" (15), and in the next few days "la Rose went back and forth between her world and the one here. Then she began to appear with more regularity, certain afternoons, always when her sister was in bed with a man" $(15) .{ }^{8}$ Mina interrogates Rosalia about why she is 
following her: had she lost her way or was she fulfilling a mysterious plan? But la Rose, in death like in life, is mute and mentally challenged, and she cannot communicate with Mina to tell her why she is there. And yet she shows a pronounced interest in Mina's sexual escapades which results in a morbid fusion for Mina of sex and death, intimacy and violence, lust and fire:

It would come upon her just like that, like a fever. At those times, she lost control of her body. She needed sex, the sex of men. Demanded it. Dreamed of it [...] She had to be taken, possessed, penetrated [...] Sometimes, she entered calm waters $[. .$.$] But some day, no matter that she shamefully tried to resist, the$ macabre dance of love and death would find her again. (18) ${ }^{9}$

Mina feels powerless to control her cravings and is compelled to give in to them, even though it comes with the very real cost of sexually transmitted illnesses, unwanted pregnancy, or violence at the hands of the men she picks up for these one-night-stands. Her sexual appetite also prevents her from seeking or finding true intimacy with anyone. When Christian, a "regular," tells her he loves her and asks her to marry him, Mina cannot imagine connecting herself to just one man because she knows her cravings will continue. Mina's desire possesses her like a spirit or lwa might possess or mount a vodouisant. Dayan explains that "the language of possession, or the crise de loa--that moment when the god inhabits the head of his or her servitor--articulates the reciprocal abiding of human and god. The "horse" is said to be mounted and ridden by the god" (19). Dayan is careful to note that the lwa depends on the availability, discipline, and commitment of the person who becomes the vessel or "mount."

Whether Mia's ailment is possession or nymphomania, Rosalia's incessant 
companionship negatively impacts Mina's life, and she is vulnerable to visitation by other spirits as well:

People spoke to her in her dreams, accused her of having started the fire herself, of descending from a hateful family, of being responsible for the death of her sister. Her nights were peopled with creatures who sought only to kill her. Visions of burning houses and banana fields in flames. Ballets of tormented spirits running amok on earth, of choking green serpents. $(24)^{10}$

Njeri Githire writes of Mina's desire in pathological terms: "Mina's encounters with men smack of mental pathology as the young woman clearly suffers from a compulsive sexual disorder" (93). Githire discusses the important thread of psychology and mental illness in Pineau's oeuvre, a preoccupation likely related to the author's own career as a psychiatric nurse in France. For Githire, Mina's illness has its origin in "ancient struggles whose scars and wounds are the visible emblems of an invisible heritage" and thus she "joins the ranks of (dis)possessed, fragmented, and estranged characters that inform Pineau's ongoing exploration of West Indian bodies and their location in West Indian history" (83). Githire concurs that "many women in colonial and patriarchal literature are depicted as malevolent creatures that provoke strong terror mainly because of their sexuality which is considered potentially dangerous" (82). Subsequently, Mina's behavior also contributes to an unsettling cultural phenomenon in which Caribbean women and black women are hyper-sexualized.

This chapter proposes an alternative reading by emphasizing Mina's sexual desire not as a mental illness but as a physical, emotional, and spiritual vodou response to her personal and familial trauma as well as to the psychic scars etched by the legacy of 
colonialism. I argue that reading Mina's sexuality as diseased only reinforces reductive arguments about the hyper-sexualized black woman, and thus reflects an interest in suppression and containment by neo-colonial, white-supremacist culture that traditionally thrived on "the incredible link forged between female sexuality and deviance [as] the most insidiously subtle way imaginable to encroach on women's bodies" (82). A vodouist reading, in contrast, underscores the pain of the slavery past and promotes an emotional healing process for the whole person rather than a symptomatic, pathologically-driven European understanding of trauma and illness.

It is critical to note that Mina's desire is a burden for her, and that she dreads the onslaught of what she calls "the craziness $[\ldots]$ the macabre dance of death" (Pineau 18). ${ }^{11}$ Rather than accept or eventually enjoy her voracious sexual appetite, she feels "like a pawn in the clutches of a twisted cosmos as she agonizes over her sexually deviant moments" (Githire 81). Sex and death inevitably comingle for Mina, and when her desire overtakes her, she knows the appearance of Rosalia will soon follow.

In Chair piment, Western medicine fails to ease the psychiatric legacy of slavery; conversely, the spiritual and emotional medicine of vodou, as well as its attention to the past, promises a cure. When Rosalia begins to haunt her sister anew Mina "naturally looked for a solution from the professionals who frequent and collaborate with the spirits of the Evil and the Good. Made an appointment with Sarah Pitagor, a Martinican medium and seer" (15). ${ }^{12}$ The Martinican devineresse explains that the only sure cure is for Mina to return to Piment, Guadeloupe, and to literally confront her demons. Sarah also prescribes prayers and potions:

seven magical prayers to recite forty times each Sunday at six o'clock; two anti- 
zombie vials containing yellowed water that smelled of alkaline; and three sugar powders to disperse where Rosalia appeared, morning noon and night, making very sure not to mix up the evening's powder with the morning's, so as not to set in motion any uncontrollable forces. $(17)^{13}$

But despite these rites the devineresse is adamant that Mina must return to the origin of her personal trauma. The association is clear: Mina can be healed from both her sexual obsession and her haunting if she is courageous enough to confront her demons. Sarah challenges Mina to face her fears: "It's simple, ma belle, you just have to face the facts, whether you want to or not" (17). ${ }^{14}$ Thus for Mina, the past is revealed to be alive and active, and just as past wounds are proven to require intervention in the present, physical and mental "illnesses" can be cured by emotional and spiritual experiences.

For her part, Bénédicte's explanations to Victor about his own depression further expand on the connection between spiritual disturbance and mental health. Bénédicte and Victor meet when they are both admitted to the psychiatric hospital on the same day, the day following Victor's first interaction with Mina. When Victor first meets Mina, she takes him home for sex, and afterwards, alone later that night, he tries to kill himself. At the hospital, Bénédicte and Victor become an unlikely duo: her, a long-term-care Antillean patient, and him, "a big White man with wild hair and the crazed look of a man possessed, his eyes yellowed by Satanic forces" (153). ${ }^{15}$ Bénédicte is re-admitted to the hospital each time that

the demons returned with a vengeance. They were everywhere. With hideous faces, they followed her, whispered insults, talked to her from the television or the radio, gave her orders [...] Of course, she tried to resist. But everyone knows that 
Evil is more powerful than Good. $(101)^{16}$

Although she understands she is possessed by contemporary and ancient demons and could even diagnose herself easily--"possession"--she is also adamant that her case is hopeless: "there was nothing to be done, the story was too ancient to resolve, the demons too rooted to untangle" (102). ${ }^{17}$

There are historical as well as cultural reasons for linking a vodouist perspective to the "madness" of the characters. As a cultural practice and religion vodou does not believe in the separation between the living and the dead, and thus it is understood that spirits can haunt, possess, stalk, or otherwise be present in the lives of the living. A vodouisant is encouraged to commune with his or her ancestors and to seek the advice and support of those who have died, in addition to serving the lwa. The lwa are the many spiritual manifestations of God who are referred to as les anges, les mystères, les saints, les diables, and les invisibles. Followers of vodou believe in the interconnection between the world of the living and the world of the dead, and the traumas of the past are understood to influence the present. Dayan writes that "when the gods left Africa, they taught their people how to live the epic of displacement. No longer simply identifiable in terms of parentage or place, they would come into the heads of their people and there urge a return to a thought of origin, a place as urgent as it was irretrievable" (16). Accordingly, while the ruptures, violence, oppression, and dehumanization of the past can take its toll on the present and on contemporary life, this psychic toll is not automatically considered by followers of vodou to be insanity or mental illness. Like Bénédicte, Victor is haunted by demons, but until his hospitalization he assumes it is chronic depression, and he only pursues Western medical treatment because he has never 
been introduced to any other option. Yet his diagnosis as "possession" is evident to Bénédicte, who prescribes the same treatment that the devineresse Sarah Pitagor prescribed to Mina: a trip to Guadeloupe, and the pursuit of holistic, spiritual healing practices to be found there.

Bénédicte is certain there is hope for Victor. Although the Western doctors have diagnosed him with chronic depression, Bénédicte instead believes that he is haunted by three demons who have not left him alone since his birth: "It was clear to the naked eye that they had done a number on him and that he would end up from Charybdis to Scylla if he didn't soon find a good gadezafe to disentangle the demons who followed him "like bodyguards" (102).$^{18}$ As a good Christian, "Bénédicte had warned him as she would have done for any other Black" (153). ${ }^{19}$ She urges him to believe her instead of the French doctors: "You can be saved. Don't listen to those charlatans. I can save you! I CAN DO IT! You have to believe me! I see them like I see you. Three demons who have not left you in peace since you were born. Remember Jesus Christ!" (107). ${ }^{20}$ Even as she becomes for Victor a teacher and a prophet, she provides a sobering warning to Mina, since Bénédicte believes that her descents into madness are the result of her failure to confront her issues in the past, when they were less ancient and more manageable.

The novel presents Bénédicte's condition in such a way as to reveal the psychiatric legacy of the traumas of slavery and colonialism. Her "ancient" Antillean problems literally stalk her and prevent her from living a well-adjusted and calm life as a Postmistress in France. She is physically and symbolically a slave to her illness, which has its psychic roots in her ancestors' enslavement and her condition as a contemporary diasporic woman from the neo-colonial departments. She admits as well as represents the 
vodouist belief that the dead never die and that therefore the past lives on. Because of the spiritual root of her problems, it is no surprise that her hospitalization and medication have no effect and that the demons pursue her without end. Although her ailment is spiritual, the French medical system tries in vain to treat her for schizophrenia. Bénédicte accuses the doctors and nurses of a dangerous blindness to the interconnection of the living and the dead: "I will speak the Truth and you will tremble from it [...] Life never dies, never, never! They are all there, together, living and dead! I have eyes to see, a nose to smell, and ears to hear them. You are blind! You are all blind!” (106). ${ }^{21}$ Instead of being believed, Bénédicte's passionate ravings serve as further proof of her madness, and she becomes one of many Antillean diasporans who are hospitalized or treated for mental illness in Pineau's fictional Metropolitan France. Moreover, she becomes one of the many "mad women" portrayed in Caribbean literature. Christine Duff reads two registers of madness as represented in Caribbean women's literature, that of the "terminal" madness and that of the temporary, creative madness that is a necessary step in the regeneration process of a character (138). ${ }^{22}$ In addition to sometimes leading to creativity and, implicitly, spiritual renewal, madness can also be read as a path of resistance to domination.

In an interview, Pineau discusses the connection between her work as a psychiatric nurse and the role of mental illness in Chair piment:

PINEAU: You saw that the psychiatric hospital plays an important part in Chair piment. Madness is also present. But are these people really mad?

LOICHOT: Right. I found very interesting this reflection on madness which could also be seen as ... 
PINEAU: Magic. Because in the Caribbean, many people hear voices, are inhabited by the devil. They visit the sorcerer, the quimboiseur in Martinique, the gadèzafè in Guadeloupe. In the Caribbean, we also live in a parallel world where the devil is never far. When a hurricane strikes, we think: 'Why did the hurricane strike Guadeloupe?' A hurricane is not a climatic incident [but] a punishment that will wash away people's sins. I remember that a few years ago, after a series of hurricanes, people marched on the streets with a priest. People prayed for it to end, as if the devil, the evil had fallen upon Guadeloupe. ("Devoured" 336) With the connection between mental illness and magic in mind, it is unlikely that either of the characters in Chair piment will be cured through Western European medical strategies, nor can their ailments be totally understood through a Western paradigm. The novel suggests that the characters need to be cured with sorcellerie and vodou healing strategies because they are afflicted with a particularly Caribbean disease: zombification. The myth of the zombie and of zombification belongs to a distinctly Caribbean worldview related to vodou. Although the figure of the "mort-vivant" or "living-dead" is also found in the traditional African religions of countries such as Benin, formerly known as the Kingdom of Dahomey, "the cradle of Vodou" (Fernández Olmos and ParavasiniGebert 4), the figure becomes transposed into the figure of the zombie during the slave trade and the institutionalization of plantation society in the Caribbean archipelago. Subsequently the development of the zombie is part and parcel of the development of Caribbean vodou. $^{23}$

In Univers intimes Duff summarizes the significance of the zombie and underscores its relation to other resistance strategies including vodou, maroonage, and the 
créole languages. She explains that many female characters in Caribbean literature who are considered "mad" are in fact zombies, whose return to creativity, spirituality, and interiority enables their own de-zombification process. According to vodou mythology, the state of zombification is the worst punishment for a person, because a zombie is the ultimate figure of submission. Disconnected from her spirituality, the zombie is just a kadav, or cadavre, in other words a body without a soul, and this zombie lacks the ideal balance between her grand bon ange and her petit bon ange (Duff 43-44). A zombie's body can be controlled by a malevolent spirit or a bòkò, a Vodou priest with ill intentions, but zombification can also be caused by an imbalance between the human and the spiritual worlds.

Zombification, while it can be caused by Black Magic, a traumatic event, or a personal disconnection, is not simply an individual torment but can also affect a collective or an entire community. After zombification, the soul-less zombie no longer controls his own body, or kò (corps), and because he no longer has a psychological or spiritual life he cannot relate to his family or community. Without one of his two souls, a person who becomes a zombie is essentially reduced to a state of slavery. In the words of Laënnec Hurbon, "zombification is the worst punishment possible because it reduces the individual to the condition of slavery, which is precisely what Vodou struggles against and challenges" (Hurbon qtd. in Duff 44). ${ }^{24}$ Depestre writes that the era of slavery meant an era of zombification for the whole Caribbean: "Colonization was the era of the general zombification of mankind" (Depestre qtd. in Duff 45). ${ }^{25}$ Nevertheless, with zombification also comes the possibility of dezombification, "the quest for renewal and healing, the search for the healing salt able to return and restore to man his imagination and his 
culture" (45). ${ }^{26}$ Cures for zombification traditionally involve the consumption of salt, known for its recuperative properties.

In the literature under study, the state of zombification is often read metaphorically and thus so is the cure. Because zombies lack their second soul, the dezombification process usually depends on symbolic consumption of salt via the reintegration of the zombie's interiority, creativity, imagination, and humanity. Duff explains that "salt, the symbol of spiritual nourishment, works to awaken the creative faculties $[. .$.$] The dezombified individual experiences a profound liberation when the$ physical, spiritual, and intellectual aspects of his being return to balance and reintegration" $(45) .{ }^{27}$ Thus a healing process that allows for the liberation of the imagination can lead the zombie to reunite his body with his lost spirituality, intellect, and creativity. A spiritual guide or Elder may be helpful to the de-zombification process, although many female characters "hold the key to their own dezombification" and therefore to their own healing (Duff 121). ${ }^{28}$ In light of a culture voudou perspective, I read the characters of Mina, Bénédicte, and Victor as zombies. While the scholarly material about Mina primarily considers her sexual pathology, and while certainly Pineau's experiences as a psychiatric nurse seem to privilege an interest in mental health, the co-existence of a vodou culture is equally legitimate, especially when considering vodou's ability to syncretize multiple religious and cultural practices. Heavy though her affliction may be, Mina also holds the power to end her suffering, yet she needs the help of Victor, a fellow zombie, to return with her to Guadeloupe and confront her past. Mina's prescribed cure of visiting Guadeloupe reveals the exemplary dilemma and paradox associated with diasporic return. For a diasporic subject like Mina, the return 
involves confronting a contested space: her hometown is the site of her difficult childhood, the location of her parents' inexplicable deaths, and the site of Rosalia's immolation in the fire that destroyed their house. Since arriving in Paris after the tragedy, Mina never once returned to Guadeloupe, nor did she keep up a correspondence with any friend, neighbour, or distant relative. In Paris, Mina followed the lead of Olga and Doug, who similarly broke all ties with "le pays" in order to pursue material and social success in France. But Olga only broke with Guadeloupe by putting on a mask of indifference to cover her inner turmoil: "In fact, the eldest Montério fought endlessly against the phantoms of the past and the angels she could never deliver" (53). ${ }^{29}$ The fruit of Olga and Doug's labour and snobbery is an incurable sterility, a "pavillion of stone that symbolized their success" $(24)^{30}$, and eventually a divorce.

Mina's diasporic life is equally ambivalent and unsatisfying: after leaving Olga and Doug's home, she moves into a one-bedroom apartment that she kept for years in the "tour Edmond-Rostand" (14), a building located in one of the notorious subsidized housing complexes collectively known as "la cité." Mina lives in a veritable enclave or ghetto of immigrants that includes a large demographic of Antilleans. This landscape is a familiar one in Pineau's oeuvre; most of her diasporic characters live in the same type of dismal, depressing, and derelict housing complexes. Mina's entire universe for the past ten years encompassed

three old concrete towers with appalling facades [...] six cubes covered with graffiti $[\ldots]$ the apartments, nothing more than chicken coops and rabbit hutches, in which the families lived [...] The cité hesitated between ruin and wreck. If you had time to kill, you could count the broken eaves-troughs, the 
hanging window panes, the greying curtains, or perhaps the laundry hanging in the wind. Jeans and sweaters, sheets and rags floating like flags without nations [...] The dumpsters overflowed with shit and rats. Sometimes, the dirty children chased the rats, while the older brothers chased different monsters, other chimeras, like golden balls and envelopes of weed. $(21)^{31}$

Mina's zombification is in part due to a spiritual death caused by living, like so many diasporans, in the grimness of the cité.

The depressed suburbs of Paris known as the banlieux or the cité are a familiar landscape for Pineau, who was born in these suburbs and admits that, unlike her contemporaries, she "did not experience an Antillean childhood in the tropics. What I knew was la cité" (79). ${ }^{32}$ Although she moved to Martinique and briefly lived there, she grew up in suburban Parisian towers similar to those described so grimly in her novels. But this urban experience is also an Antillean childhood, albeit a diasporic one, although without the intangible benefits of the tropical sun, the sea, the vegetation, or the bosom of community and familial relations. Nevertheless these cités are Antillean too because of the people who live there quite separately from, and often less comfortably than, the French communities alongside which they live. Pineau's characters, most often migrants to France from Guadeloupe or from another former colony, experience the deep racism and cultural superiority of their French neighbours. And yet in Chair piment Pineau also discusses the contradictions and dualities of returning to Guadeloupe in order to show the extent of the wounding and the ambivalent experiences of diasporans.

Unlike the protagonists Gisèle in L'Exil selon Julia and Félicie in Un papillon dans la cité, Mina does not dream of the lushness of Guadeloupe or the bosom of an 
extended family she has left behind. Instead, she isolates herself from her past and sympathizes with her Guadeloupean best friend Lysia whose daughters also experience ambivalence about their home country. The three daughters Jessy, Manon, and Sofia are not quite accepted in France, and yet they are mistreated by their peers and cousins when they return to Guadeloupe for their summer holidays. ${ }^{33}$ Mocked for their accents because they "rolled their 'Rs' and put on airs," the girls wear American labels and do not fit in anywhere; like their mother's endless financial sacrifice to pay for plane tickets and souvenirs from France, their unbelonging is part of their "tribute" and "négropolitaine visa" (116-117). ${ }^{34}$ In addition to the negative treatment they endure in Guadeloupe, Lysia's daughters are also set apart in the country in which they live, France, where their peers dismiss them as not quite French enough, not quite legitimate and complete citizens. ${ }^{35}$ Recalling the rags hanging "like flags without nations" that flutter forlornly from the balconies (21), the diasporans in Chair piment live all mixed up in the cité: "They came from everywhere and from anywhere ... Bitter in exile, drunk with nostalgia" $(23){ }^{36}$

The examples from Chair piment suggest that ambivalence and un-belonging are inevitable for diasporic subjects who are caught between two or more cultures, nations, races, or languages. Despite the English lessons from a Mauritian girl that will hopefully open the way to higher education, Lysia's daughters will always be in between France and Guadeloupe, in between belonging and unbelonging. ${ }^{37}$ Whereas even minimal acceptance in French society could have economic and political benefits, what of the spiritual and cultural health that is lost with every new French advantage? How long until Guadeloupe is entirely lost to Jessy, Manon, and Sofia? The loss of origin and home is 
the cost of integration and assimilation in the Métropole. In Pineau's novels, diasporic disenfranchisement, racially-informed poverty, and limited social mobility leads to a nightmarish life without end, an imprisonment of the soul that understandably leads to depression, zombification, or a disordered possession: "Most people just waited for the end of the nightmare and looked for any escape route $[. .$.$] They felt imprisoned there,$ crushed by life. Some were always in high-alert, some seemed to be pursued by evil spirits much like the ones who chased Mina" $(22) .{ }^{38}$ Like the maroon who is often caught in between the ordeals of the plantation and the struggles of life as a fugitive, the banlieu characters in Pineau's novel are likewise in a perilous intermediate zone of not-quite belonging.

\section{Thwarted Motherhood in Chair piment}

In historical and cultural representations, the slave woman's womb is frequently rendered as a literal tomb for her unborn children. Because slave women were sold as potential brood mares, many practiced terminations in order to prevent bringing more children into slavery. Perhaps not surprisingly, Caribbean literature features many black women characters who either negate their own motherhood by infanticide, abortion, or neglect, or who for some reason cannot become mothers naturally. ${ }^{39}$ The historically common occurrence of rape in part motivated some of the terminations on the plantations. Slave women were frequently raped by their masters, and the reality of miscegenation, métissage, and mixed-race people on the islands is largely due to this alltoo common practice. Critical scholarship must therefore be careful when celebrating hybridity and métissage as a critical stance or positive attribute of Caribbean society; 
mixed-race identity is, at best, an ambivalent experience. In the case of rape, the woman's body becomes both the site of the initial violence and the frequent reminder of the trauma, and from her womb the children conceived by this violence are carried and, if delivered, always regarded as memento mori of the colonial oppressor's brutal act. In Marie-Célie Agnant's Le livre d'Emma, Emma's mother and aunt are symbols of such miscegenation. Simultaneously appreciated and reviled because of her light skin, Emma's mother disdains her own daughter because she is born too dark. The legacy of rape, perhaps committed generations ago, thus rears its head in the complicated genetic compositions of Antillean people and in their many shades of different colours--another psychic and physical scar of colonialism and slavery.

In yet another example of how the bodies of Caribbean women are exploited, in Pineau's works the spectre of incest looms large and is unnervingly frequent. In her work, the abuse of children demonstrates "a wider pattern of social and emotional disorder the same pattern, born of slavery with its brutal disregard for individual rights $[\ldots]$ Presiding over the narrative is the violence of nature itself" (Ormerod 115). A common trope in postcolonial literature equates the land with the body of a woman, and thus the land's "colonial rape" by the European oppressor. Incest figures in several works by Pineau including L'espérance macadam, Morne câpresse, L'Éxil selon Julia, and Chair piment. Although Ormerod notes that incest is not a subject usually broached in Francophone Caribbean literature (115), incest and the sexual abuse of children in general is presented in several contemporary Anglophone novels including Tessa McWatt's Out of My Skin (1998), Shani Mootoo's Cereus Blooms at Night (1996), Alice Walker's The Colour Purple (1982, 1992), and Edwidge Danticat's Anglophone/ Creole 
Breath, Eyes, Memory (1994).

In Chair piment, the incest plot is at the heart, indeed at the physical centre, of the novel's family saga, and it is what poisons the possibility of healthy love for the characters. Githire writes that here incest is asked "to bear the weight and key meaning of the entire novel" (87). Indeed Suzon's unrequited love for her half-brother Melchior, Mina's father, leads her to bring about the many catastrophes that affect his family. In addition, Mina's first sexual relations are with Doug/Douglas, her sister Olga's much older husband. Although hesitant at first to break this taboo, Mina and Doug have a sexual relationship for the better part of a year while Mina is still a teenager and being raised by Olga and Doug in their suburban French house. Due in part to the frequency of rape and incest in the literature, whether past or present, the Caribbean female body is thus vulnerable on many fronts; in fact, much less commonly in Caribbean literature are women portrayed as having healthy and positive relationships with their own bodies or with other bodies, especially male bodies. Sexuality is often portrayed ambivalently, as is motherhood.

Since natural motherhood is fraught with danger and is often itself a result of an act of violence, including rape and incest, Caribbean literature includes many women characters who are surrogate mothers to other women's children. The presence of the surrogate mother seems to be as common as that of the non-mother. Fictional surrogate mothers include the grandmothers both named Man Ya/Julia in Un Papillon dans la cité and in L'Exil selon Julia; Minerve in Pluie et vent sur Telumée Miracle; Man Tine in Joseph Zobel's La rue Cases-Nègres; and Mama Yaya in Moi, Tituba, sorcière noire de Salem. In these novels, children are raised by grandmothers or aunties or family friends 
after their natural mothers die, go overseas for work—coming back for them or not—or simply disappear, and these surrogate mothers often impart spiritual and cultural knowledge to the children they raise. Naudillon writes of women's role as mothers and spiritual poto-mitan:

it is the women themselves who undertake and assure the work of physical and spiritual reparation for their peers. Femme relais, femme médiatrice, inexhaustible fountains of wisdom, they are the guardians of time and history, recorders of matrilineal legacies, just as they are the guardians of community culture and therefore the guardians of humanity in general. $(84)^{40}$

Characters like Man Ya are emblematic of the grandmother-figure who transcends her own suffering in order to mentor the younger generation. ${ }^{41}$ Ancient and powerful knowledge is written therefore in women's bodies; subsequently, women characters serve as guides and mentors, if not to their own children since natural motherhood is impossible, then to those they raise in lieu.

In Chair piment, Suzon Mignard is the ultimate figure of impossible motherhood. Though she dreams prophetically of the eighteen children she will give to her beloved Melchior, her maternal desire and love for him become perverted into dreams of evil and murder. Her deeds lead to the deaths of Melchior and his two wives; to his daughter Rosalia's mental and physical disabilities; to his wives' miscarriages; and to the residual trauma suffered by the survivors, Olga and Mina. Most nefariously, Suzon's misdeeds are kept so secret that she retains her position as a surrogate grandmother for Mina; markedly opposed to the emblematic Caribbean grandmothers Man Ya in L'Exil selon Julia, Reine Sans Nom in Télumée Miracle, and Man Tine in La rue Cases-Nègres, Suzon is a 
destroyer of families and an enabler of trauma, not a guardian of restorative cultural knowledge. $^{42}$

Worth noting at this instance is the significance of another pervasive myth that associates women with the poto-mitan (poteau-mitan), the center post erected in the middle of the hounfort, the venue for Vodou ceremonies. Dayan writes that the potomitan "images the traffic between heaven and earth" and that it is "the place where the way up and the way down are no longer contradictory, for as we have seen, the loa ascend or descend: coming up out of the waters and into the heads of their people" (17). In Chair piment, Suzon is a negative embodiment of this post or portal; she is the conduit that determines the life and death of the members of Melchior's family. Whereas women are usually valued in vodou ceremonies for their role in productively bringing about the communion of the humans with the spirits, as well as for sustaining and transmitting the cultural life force, Suzon provides an alternative to the poto-mitan myth.

Through her dealings with "le Mal" and because of the festering of her obsessive resentment, Suzon makes a devil's pact that will be her undoing. Over the years, she becomes associated with several sinister female archetypes:

The demon $[\ldots]$ The she-dog with the yellow fangs $[\ldots]$ The witch who visited fifty-four gadèzafè and ten sorcerers in order for love to be victorious. The impure who called on the water's evil spirits, who blocked the brakes of the Titan truck, hailed for madness, thunderbolt and fire. The miscreant who prayed so that misery could reign on the morne Calvaire. The serpent who lived in the body of the scorned Suzon $[. .$.$] the crocodile-woman [\ldots]$ the old hag who, twenty-one years after her last crime, feared to open Mina's letter. $(174-175)^{43}$ 
The tragedies that befall Mina's family are wished for, paid for, and ultimately inspired by Suzon's malevolent desires. From the magician "Lautréamont de Maldoror” she “extracts, in 1978, a twenty-year contract for evil deeds against Melchior's descendants" (176). ${ }^{44}$ Tonnerre-de-Dieu moves the river water to drown Marie-Perle and later he arranges for Melchior's death (176); Branquignol causes Médée to suffer five miscarriages before Mina is born; Solstice III ensures that Médée remains in eternal darkness (177); and Apolythe Trident causes the accident that kills Médée (176-77). Suzon's plots determine the fate of Melchior and his descendants. When she receives Mina's letter announcing her return to Piment after twenty one years, she is terrified of being finally found out.

Although on the one hand Suzon can be read as an active female agent for attempting to determine the life she desires, her actions bring nothing but tragedy to Melchior's family and poison her own life. Pineau underscores Suzon's obsessive love and the steps she takes to wreak havoc in order to show both the complexity of vodou spirituality and the limited choices available to women in mid twentieth-century rural Guadeloupe. While the forces of Black Magic do exert their immense power, they do so at a price, and Suzon never in fact enjoys the return of Melchior's affections. As Berlus too easily can see, the evil that Suzon unleashed on Melchior turns finally towards her:

The darkness reigned widely and for too long, without limits or remorse. The darkness grew like a weed that strangles and devours everything in its way. When she couldn't find any more flesh to consume, the darkness turned towards you who invoked it. Towards you, like a starving dog who attacks its owner. Evil is not sated ... What can I do to stop the powers that you yourself set in motion? 


\section{$(156)^{45}$}

Suzon's poisoned, isolated life, like her blindness, is the punishment for her crimes. Unable to mother or grandmother her own children, responsible for the deaths and suffering of too many others, Suzon is a controversial figure that reifies the common Caribbean literary trope of impossible motherhood as well as the poto-mitan conduit between the living and the dead. Simultaneously, she inverts the idealism associated with the surrogate mother and grandmother. Her active, independent choices bring her to the limits of Vodou spirituality; while Mina and Victor can be saved by vodou, Suzon is destroyed because she relentlessly chooses the wrong side. In one sense, vodou punishes her for choosing "Le Mal." The Loneliness of Angels also demonstrates both the productive potential and the destructive limits of vodou spirituality, especially for the female characters. As in Chair piment, the female characters in Chancy's novel struggle against traditional gender norms. Here too the trope of surrogate motherhood takes on tremendous, and this time, positive, significance.

\section{Surrogate Motherhood and Syncretic Religion in The Loneliness of Angels}

Myriam Chancy's third novel The Loneliness of Angels is a family saga spanning

several generations, continents, and temporal periods. Divided into three parts and a coda, Part 1, "Fallen Angels," has three chapters narrated by Ruth, Catherine, and Romulus. Part 2, "Survival Strategies," is from the perspective of Rose and Catherine; Part 3, "Illusions," returns to Romulus and introduces Elsie's voice. The Coda is granted to Catherine. Narrated through these multiple voices and perspectives, the novel is a nonlinear, time-travelling journey across multiple countries, cultures, and political situations. 
At the core of the novel is the exploration of one family's spiritual gift, a gift that is inherited across the generations as both burden and blessing. Significantly, the novel is vast in scope but situated in particular historical contexts, and the characters' understanding of their gift is affected by political situations in Ireland, Canada, Haiti, France, and the United States.

The novel's first part closes with Ruth's brutal murder, a death that she anticipates and in part welcomes, knowing it is a necessary inciting action for the correct unfolding of her family's story. Indeed, her niece Catherine's return to Haiti from France for the funeral precipitates and enables her own dezombification process and the awakening of her spiritual gifts, in much the same way that Elsie's arrival in Haiti several generations beforehand was a psychic return to the land she had dreamed of for years in her timeshifting dreams. More so even than in Chair piment, The Loneliness of Angels demonstrates the productive potential of a syncretic vodouist worldview and culture. The novel narrates familial and community histories and memories of trauma in a polyphonic manner. As mentioned above, vodou is a religion of resilience that is both ancient and constantly shifting, founded by the interaction and exchanges between African slaves and indigenous Caribbean peoples. In many ways, vodou manages to walk the line between indigeneity and diaspora at once, and the Haitian Vodou represented in The Loneliness of Angels is, accordingly, a religion of travellers, sojourners, and contemporary maroons. Yet in neither Chair piment nor The Loneliness of Angels is vodou uncritically celebrated. In the novels, vodou retains its ambivalence, but so too does the experience of diaspora, the trope of return, and mixed-race identity. Possibly empowering but not an absolute cure-all, vodou is a path towards healing, resilience, or, as for Suzon Mignard in 
Chair piment, destruction. In both novels, spirituality and spiritual awareness is shown to be a gift and a burden, a refuge and a prison, a maroonage from slavery and a sign of insanity—and in each case these different states and spiritual practices derive from vodou. I contend that a vodou culture and worldview enables potentially productive possibilities for diasporic subjects, mixed-race subjects, "mad" women, and women in general. While the novels by Pineau and Chancy reveal the limits of vodou and its complex and destructive potential, The Loneliness of Angels reveals, especially, how vodou can help to recuperate female subjectivity.

In The Loneliness of Angels, Haiti is the emotional centre of the novel even though the characters have roots in Ireland, Syria, England, and Africa and live in Miami, Paris, Montreal, Chicoutimi, and Des Moines. Haiti is the powerful space where all of their experiences collide, fuse, and break apart again. Though it could be argued that the myth of Ireland and its supernatural magic also compels Elsie and Romulus, the novel is a love-letter to Ayiti. Ireland feeds and haunts the novel both in the mythic past as well as in the present, but it is when the ancestor-prophet-primogenitor Elsie sails to Haiti from Ireland that the family's saga is put into motion. Similarly, when Catherine returns to Haiti from France after Ruth's murder, both her own prophetic (re)birth and her cousins' mystical future are made possible. The novel in this way challenges notions of indigeneity and diaspora by asking how long it might take until a person becomes indigenous to a place, and whether or not that depends on arriving by choice, like an immigrant, or arriving by force, like a slave.

The metaphor of the labyrinth that Chancy notes in the Acknowledgments is a physical explanation for the circuitous story lines and the characters' many journeys, but 
it also represents how the saga stands out of time, in mythic or quantum time, even though the family's experiences happen in relation to historical events. Nevertheless, Elsie's ongoing surveillance of the characters, although she lived many generations ago in the past, demonstrates the multiple registers of time in The Loneliness of Angels and ultimately their concurrence. Here, the past lives on in the present, people dream memories they have never experienced, and they recall faces they have never seen. Mythic time in the novel relates to the lived experience of postmemory, in which trauma memories are remembered and inherited by non-survivors. Just as a labyrinth can open the door to contemplation, intention, and powerful energy for the person walking it, the characters' memories in Chancy's novel are portals for sacred connection across time and space.

For Hirsch, postmemory "describes the relationship that the 'generation after' bears to the personal, collective, and cultural trauma of those who came before--to experiences they 'remember' only by means of the stories, images, and behaviours among which they grew up [...] [but] transmitted to them so deeply and affectively as to seem to constitute memories in their own right" (Generation 5). Although the experience of received postmemory "is distinct from the recall of contemporary witnesses and participants" (3), it can also be overwhelming. Rose is burdened by her empathic work as a witness to the suffering of the victims of Duvalier's dictatorship, and Lucas, Catherine, and Romulus are likewise affected by the magnitude of their family's memory. Hirsch notes that "to grow up with overwhelming inherited memories, to be dominated by narratives that preceded one's birth or one's consciousness, is to risk having one's own life stories displaced, even evacuated, by our ancestors" (5). Here again ethical engagement 
relates to narrative genre: in The Loneliness of Angels, postmemory's connection to the experience of mythic time reveals the ambiguity and fluidity of memory and the inherent commonality to both of storytelling and non-linear narration. Postmemory and mythic time has resonance with the worldview of vodou which believes that people live on in spirits and lwas, that the dead do not die, and that we carry with us experiences from the past. Similarly, indigenous cultures have understood for years that time and history are not linear, and that the spiritual plane co-exists with the human plane. The poto-mitan is itself the symbolic conduit for the connection between the two planes; in Haitian culture, women are regarded as the embodiment of this route between the spiritual and human worlds and the mediums for connection.

Through its invocation of Ruth and Elsie as poto-mitan within their own families, both in the sense of preservers of cultural knowledge and as mediums for spiritual connection, The Loneliness of Angels presents an extended family that, ultimately, is maintained by the sustained effort of unusual and independent women characters. This section of the chapter focuses on Ruth and Elsie, the contemporary and past motherfigures of the family whose narratives bookend the novel. Both women struggle to maintain their independence while at the same time understanding that the role they play is pre-determined by larger supernatural forces. Both characters incarnate a syncretic religious understanding and both become surrogate mothers to their charges. Taken together, Ruth and Elsie take up the mantle of surrogacy as part of a grander purpose of mentorship and spiritual work that recognizes alternate forms of motherhood and family.

In The Loneliness of Angels, Ruth becomes the surrogate mother first to Lucas, then to Catherine, as well as more peripherally to Romulus, after their own mothers 
disappear or die. Spiritually, Ruth is also a mother-figure to her nieces Estelle and MarieClaire, as well as a spiritual mother and guide to her many followers, who know her as Ezili Le Flambo. Ezili Le Flambo, or Erzulie Flambo, is the Haitian Vodou lwa associated with motherhood and children; she is also the patron of "motherlessdaughters," as Lucas reminds Ruth just before Catherine comes to live with her (Loneliness 46). In some ways Ruth is a quintessential Caribbean surrogate mother: after an early experience of a missed romantic connection with JP, Lucas' father, she never marries, and yet in her role as piano-teacher she mentors and mothers many children of the neighbourhood. Moreover, her surrogacy begins in earnest with the arrival, on her doorstep, of JP and Lucas and, later, Catherine's arrival from Canada after the death of her mother Rose.

In her novel, Chancy gives her protagonist Ruth several qualities shared by the biblical heroine, as well as life experiences that similarly involve the themes of foreignness, diaspora, protection, return, selflessness, and the relation to a messianic line of seers and visionaries. In the Hebrew Torah, Ruth is the figure renowned for her selflessness, capacity for friendship, and her ability to be loyal to her mother-in-law Naomi's beliefs. Set during a time of spiritual depravity, The Book of Ruth is understood by both Christian and Jewish theology to demonstrate the themes of God's love and redemption. After the death of her husband, the Moabite-born Ruth decides to stay in the household of her mother-in-law Naomi and be a companion to her in her old age, even though that means accompanying Naomi to her homeland in the land of Judah and worshipping her god, the God of Israel. Like Abraham before her, Ruth willingly leaves her birth-place and her people in order to make a commitment to Naomi and to the God 
of Israel. Ruth's promise to Naomi is well known:

Do not ask me to abandon or forsake you! for wherever you go I will go, wherever you lodge I will lodge, your people shall be my people, and your God my God. Wherever you die I will die, and there be buried. May the Lord do so and so to me, and more besides, if aught but death separates me from you! (The Holy Bible, Papal Edition, Ruth. 1.16-17).

Even though she is a foreigner in the land of Judah, God protects Ruth and rewards her commitment with a son who himself becomes part of the Messianic Line leading to King David and, eventually, to Jesus Christ. Described and considered as a foreigner by her society (Loneliness 58), Chancy's Ruth embodies the position of a mixed-race, religiously-syncretic figure that bears the burden of this heritage while also being strengthened by it.

Although the novel does not overtly comment on the connotations of Ruth's name, it is nevertheless a novel in which Judaism is significantly present in a manner that warrants a distinct and sustained discussion of its own. Sarah Casteel pursues the significance of Jewish history in the Caribbean in her forthcoming Calypso Jews: Jewishness in the Caribbean Literary Imagination; the second chapter of this volume, entitled "Marranism and Creolization: Myriam Chancy and Michelle Cliff," focuses on representations of Jewishness in The Loneliness of Angels and in Cliff's novels. In The Loneliness of Angles, the Jewish references relate to the novel's particular portrait of religious syncretism, which the character of Ruth epitomizes. While her mother is from a line of Haitians descended from African slaves, Ruth's father is the son of a JewishSyrian merchant who came to Haiti to escape repression in his native community. Ruth's 
father, raised in Haiti, worships the Jewish God as well as the lwas of Haitian Vodou; he studies Kabbalah and is a member of secret vodou societies; and he has a hidden altar in his study in which he keeps a figure of Moses holding the Ten Commandments as well as a figure of Papa Legba disguised as St. Peter: "These were his gods and before them he placed bowls of water, a snifter of rum, and the occasional orange" (38). When supervisors from the Church arrive to pursue their anti-Vodou campaigns, Ruth's father covers up the altar because it contains both Jewish and Vodou imagery.

Chancy's portrait of Ruth's family gestures to a centuries-old link between Jews and the Caribbean. This link was made manifest by several waves of migration since 1492 to the present day, as well as to a thematic link between the experience of hidden Jews, known as converso Jews or marannos, and the experience of maroonage. Jewish migration to the Caribbean and South America began at the time of the Inquisition, when waves of Iberian Jews fled Spain and Portugal via the Netherlands and England and remade their lives in the New World, usually working in the sugar industry or as merchants. ${ }^{46}$ In the novel, Ruth's father is a Syrian Jew (ie. Mizrahi) who hides his religion once he is in Haiti, just as the Sephardic Jews of Spain and Portugal who remained in the Iberian peninsula or their colonies after the Inquisition practiced their religion in hiding (maranno) or superficially converted to Catholicism (converso). Sarah Phillips Casteel writes that Chancy's association between Jews and the Caribbean "signals an investment in a non-competitive project of comparison that highlights the intersectionality and porousness of apparently distinct histories" (110). Chancy invokes the maranno experience by rendering Ruth's family as contemporary conversos and marannos in Haiti, and this portrait draws a parallel between the oppression of Jews and 
that of vodouisants in Haiti. As a result, the book underscores the centuries-long presence of Jewish life in the Caribbean.

Significantly, Ruth's father imparts to her the essential core of his own syncretic belief system - that is, that Jewish Kabbalah, Catholicism, and Haitian Vodou are all different expressions of one faith: "Her father reopened the magical book with the word Kabbalah written on its spine and stabbed at the diagram [...] 'The tree of life ... mysticism, vodou,' he muttered, 'it's all the same"' (44). He explains that just as Kabbalists believe human beings are made of five elements that have to be kept in balance, Haitian Vodou believes in the tripartite balance of the ko (the body), the gwo bon anj (le Gros Bon Ange), and the ti bon anj (le Petit Bon Ange), while Catholicism is founded on the co-existence of the body, the soul, and the Holy Spirit: "Tell me, Ruth, how is it any different? Remember this Ruth: whatever they're afraid of, they'll call it the devil. Whatever stands in their way, they'll call primitive and backward. So don't worry about what they say. Follow your heart even if what it seems to be telling you makes no sense. Le coeur, c'est tout!" (43). Ruth is raised to respect the heart of the matter, rather than the outward show, of spirituality.

As Ruth grows up, she too lives her life with a syncretic blend of the three religions: she is an avid church-goer, yet she also teaches her surrogate children to chant her father's ancient Jewish prayers, while never losing sight of her connection to Papa Legba and the Vodou lwas. She worries sometimes about the appropriateness of her mixed-up heritage, especially in her choice to share it with Catherine and Lucas: "For years, she had heard the girl saying the [Jewish] prayer as she knelt by her bedside, hands clasped together. Catherine would then recite the Lord's Prayer, then a Hail Mary, as 
Rose had taught her, and Ruth would stand, slightly aghast, against the doorframe of the child's bedroom" (36). But eventually Ruth makes peace with the syncretism that she herself had long ago accepted in her father and in herself, and she begins to understand that it is integral to the larger spiritual project of which her family is a critical strand:

But what could she have done differently? Did it matter that she was mixing different beliefs, different prayers? The end result would be the same. The girl belonged to all of them and fate could not be avoided [...] It was too late to undo the things she had done and Catherine would be well served by the unorthodoxies of her upbringing. This is what made Catherine different from all those who had gone before her: she was a walking contradiction and still survived. (37)

Ruth has to accept that it is a blessing that all the faiths and cultures live in her at once, and that this is why her gifts are powerful and potent. Like the Biblical Ruth, she begins to understand her role as a mother, guide, and protector of her family's messianic line. After her father's death, she maintains her connection to Papa Legba, the lwa of the doorways, paths, and crossroads who must be invoked at the beginning of any Vodou ceremony:

She knew her gifts were not of the same order as the children's. Her patron saint was St. Peter or Legba, after her father. She opened doors; she did not go through them. She understood the ways of the gods and respected them but she was not one of their emissaries, at least, not like Lucas and Catherine and all the others. She witnessed. She supported. She tried to keep those meant to be doing the real work alive. (47)

As the key guide of this generation, Ruth's prophesied death is the catalyst that allows 
Catherine to return to Haiti, awaken her dormant gifts, and motivate her to take on the mantle of family and spiritual protector with which she can save her cousins Lucas, Marie-France, and Estelle. With her death, Ruth ensures the family's redemption by becoming a poto-mitan, a portal or "channel between the dormant and waking worlds" (58), a kind of martyr who ensures the safety of the next generation.

Part of what contributes to Ruth's strength and her capacity to help others is her realization that she is the keeper of the diverse memories, heritages, and spiritual traditions of a mixed people: "Never mind that she had a memory that paired the wanderings of her father's people with the rolls of the drums of her mother's people in their native land where the earth was dark and black like freshly mined coal" (57). Ruth has a memory for layers, concurrence, and simultaneous narratives, and she experiences postmemory that is not her own. She also understands her role and position in the messianic line of seers to which she owes both her visionary gift and the burden of her life experiences. When she first meets Rose, Catherine's mother, who is too fragile to withstand the pressure of her responsibility as a visionary and empath, Ruth understands that the actions of their lives are predetermined:

Ruth could look at Rose and see the girl's famed, notoriously crazed, greatgrandmother Elsie as if the woman existed in the mirror of the girl's eyes. She could see that Rose was just one pearl on a string that led all the way back to distant lands, all the way back to Nigeria and to Ireland, to the wandering geography of her father's people, her people. To each generation there was a seer born, and, in turn, each was broken, her gift reviled. (54)

In Rose's eyes Ruth can see the young woman's fragility and early death, but Ruth 
refuses to help her to manage her gift. She dismisses Rose because she knows that refusing is the correct action in the order of things: "Ruth realized then that the girl had known that she would refuse and that some day the debt would have to be repaid. Rose was fragile but she was no fool. She knew already that she carried a girl, a seer, and that she would not live to see the day when the girl would come to know the gifts of her lineage" (55). Despite her refusal of immediate help, Ruth understands that she will have to guide and look after Catherine, the next seer, whose protection is necessary to fulfill the family prophecy.

After Rose's death Ruth takes up the mantle of one of Rose's empathic charges, that of the activist and journalist Coco who was disappeared by the Duvalier regime, but whose ghost visited Rose every night. Ruth takes up Coco's duty and writes underground letters and articles to the activist women of Haiti. Addressed to the "Fanm Vayant," Ruth imagines her audience to be "Seeing Women," visionaries and activists of Port-au-Prince. Ruth prints the letters herself at home and circulates them amongst the vendors and market women: "She signed her pieces, 'Ezili Le Flambo,' honouring Coco and Rose, both" (56). In her closing missive to her underground women followers, on the eve of her murder, Ruth includes an epigraph from "Psalm 133" of the Old Testament:" 'Hinei mah tov omah nayim shevet achim gum yachad.' / [Behold how good and pleasant it is when brethren dwell together in unity. —Psalm 133:1]" (60). This reference re-affirms Ruth's connection and respect for her Jewish heritage, but it also reiterates something her mother had once said to assuage Ruth's hesitation about discovering she was Jewish:

"Does this mean that I'm a 'Jwif'?" Ruth asked.

"Yes," her mother had said. "Nou tout se Jwif. Even those of us who kick 
ourselves, not knowing any better, and set ourselves on fire as if we might consume the past by repeating its offences." (42)

By declaring that "all of us are Jews," Ruth's mother underscores the connection between all people and especially those who have been metaphorically kicked like the straw-man effigy of Judas at Easter. With her use of Psalm 133 in her letter, Ruth once more reaches for a sense of planetary, intercultural solidarity, and declares her hope for a time "when brethren dwell together in unity" (60). "Psalm 133," traditionally referred to in Hebrew as "Hinei Mah Tov," is often sung by Jewish communities during Shabbat services. In this last letter, Ruth urges for her followers to persevere: "Fanm Vayant, / There is nothing you cannot do. / There is an order to the universe written in the stars, seen and unseen" (60). Thus Ruth gestures towards both her Jewish and Vodou spirituality; the reference to Psalm 133, along with her farewell in the guise of Ezili Le Flambo, honours her life-long promotion of a compassionate, syncretic community of visionaries.

And so the Jewish prayer that the family passes on through the generations, "l'dor va dor," takes on renewed symbolic significance. Taught from parent to child in times of fear and crisis, the prayer offers the family comfort and the promise of the Archangels' protection. Not a particularly common Jewish prayer, in Loneliness of Angels it nevertheless comes to stand in for the family's multi-faith past, and it dovetails nicely with their Vodou culture and Catholic practices:

Before the girl went to bed at night, Ruth taught her to say: 'May Michael be at my right, Gabriel at my left, Uriel in front of me, Raphael behind me, and above me, the Shekina - The Divine Presence.' She taught Catherine the prayer when the girl woke up with nightmares about her mother, about Fritz, when she saw 
women in red dancing wildly against the walls. Ruth's own father had taught her the prayer when she had been a child. For protection, he'd said [...] this was a sacred prayer to the archangels; to Michael, messenger of God; to Gabriel, the strength of God; to Raphael, the healing power of God; to Uriel, the light of God; to Shekina, the feminine presence of God. In illness or in wellness, she'd told Catherine, as her father had told her, in illness or in wellness, these words shall protect you. (36)

For Catherine, the prayer also serves to connect her to her mother: "The prayer always left me feeling quiet and safe, as if somewhere beyond was a force that would connect me to my mother, wherever she was, a force that was not as cruel as I imagined, that would unveil heartbreak as a different reality in the fullness of time" (84). The many generations of the family, whether or not they are natural children or spiritual descendants, learn the prayer to manage their own supernatural gifts. In asking for protection from the Archangels, the prayer privileges the divine forces of communication, strength, healing, light, and femininity, rather than privileging God per se. Not dissimilar to the Haitian Vodou lwas, also known as les anges, the angels are invoked for protection and companionship and for the divine characteristics they represent. Figures in both Catholicism and Judaism, the angels are intermediaries between the human world and God.

The novel's title, The Loneliness of Angels, further extends the link between Catholicism, Judaism, and Vodou. Strikingly, the typesetting of the book's cover highlights and distinguishes the following letters from the rest of the title: L, O, A, S which spell, of course, loas, and is pronounced identically to lwas. The author's thanks to 
the loas in her "Author's Note \& Acknowledgments" only emphasizes the concord between the religions. Fittingly, just as the book jacket's printed gesture to the "LOAS" heralds the beginning of the book, Chancy's acknowledgment to the spirits closes the text: "As always, lastly but chiefly, I give thanks to all my ancestors and to the loas." Spelled identically to the letters of the book's title, these final words unravel the novel's code in a celebratory example of Kabbalist-like word-play.

In The Loneliness of Angels as in Chair piment, spiritual motherhood is taken on by a childless woman, Ruth, as well as by a natural mother, Elsie, who also becomes a surrogate mother to others. Due to Chancy's use of quantum time or mythic time in The Loneliness of Angels, Elsie is both the distant ancestress as well as the concurrent mentor to the family's seers. Rose, Lucas, Romulus, Catherine, and Ruth all see or feel Elsie's presence in different ways. Indeed, the novel's labyrinthine saga is just shy of recounting a narrative of incest, so vaguely but decidedly are the characters' lives interconnected but never satisfyingly untangled for the reader. Perhaps the vagueness of the characters' family tree confirms that, in the case of fulfilling a prophecy and inheriting the gift of second sight, blood is less a factor than chosenness and fate. Elsie demonstrates with her ceaseless witnessing, first from her place of indentured labour in Ireland and then from Haiti after she has sailed there to put down roots and build her family, that it is through their psychic abilities that the characters are connected and bound together.

Elsie is the Ur-Mother to the characters of Loneliness of Angels: a white Irish woman rather than an African ancestor, Elsie is the progenitor and guardian of the family's supernatural gift. The family's roots are tangled and include unknown African, Irish, English, Syrian Jewish, and French origins, and it is only in the novel's penultimate 
chapter dedicated to Elsie that Chancy unravels the complex knots of the story. The characters of the novel are all connected to Elsie, either by blood or by spirituality. It is Romulus who, during his healing trip to Ireland with his mentor Father Tim, finally understands how the puzzle fits together ${ }^{47}$ Romulus realizes that the woman he'd seen in his dreams when he had been sleepwalking through the world was both Catherine's great-great grandmother and Father Tim's ancestor. He could not trace exactly how and when the genealogy of their ancestry overlapped, but he knew with certainty that the ghost of his hauntings and the woman in the photograph were one and the same. (318)

Elsie's "Work" is to find and support seers and empaths who have second sight and to contribute to fulfilling the prophecy the "elders up above" have already ordered (327). Because she also has the ability to "navigate the spaces between times" (329) and make "time-defying journeys" (327), she appears to Rose, Romulus, Ruth, Lucas, Catherine, as well as to Father Tim. After she has a vision of a Caribbean Venus known as the Vodou lwa La Siren, Elsie understands that she must go to the islands and "leave the Work to take up her role as a mother and let the new growth carry forward" (342). Ultimately, like Ruth, Elsie's role is also that of a poto-mitan, and she must open doors and portals for others; moreover, Elsie is associated with the mother-figure, Ezili, the lwa of motherhood and motherless daughters, and the Créole/Vodou equivalent of her name, Elsie.

In these ways Elsie represents the fusion of ancient Old World pagan beliefs with New World vodou spirituality. Although she hails from Ireland at the time of English colonial rule, her faith is still more pagan than Christian. Her "Work" is informed less by Christianity than it is by the spirits of the natural world all around her. She comes from a 
line of seers, and her own father taught her to manage her gift. When Elsie has a vision of "a blinding sun and a stench of burning" and sees "her hands turned the colour of chestnuts from their usual chalk-white," she begins to understand that she needs to go to the New World, to the islands: "It was then that she'd seen the vision that had driven her this far: a woman with knotted strands of stiff hair rising from the ocean like the Venus on her half-shell clam" (325). Elsie's vision shows her an apparition of La Siren, and when she eventually arrives in Haiti, Elsie carries on her work, "a white woman who spoke to the gods, the loas of the land" (342). For Elsie, the spirits are the same, whether in Ireland or Haiti.

One of Elsie's charges is Romulus, a former piano student of Ruth's in Port-auPrince and later one of Ruth's murderers. Elsie tries to mentor him but he regularly gives her grief and heartache: "Quite often she believed she had made the wrong choice, a mistaken choice that the elders up above were too stubborn to undo. This hedonistic man did not seem up to the task they had set before him" (327). But Elsie understands that her actions are not entirely her own, and that she is but contributing to a pre-existing plan that is beyond her comprehension: "But given her own place in the order of things between earth and sky, she had to persevere" (327), and so she continues to follow and guide Romulus, "still hoping against hope that he would be the one to realize the prophecy" (325). It is only after much misery including Ruth's murder and his son Christian's suicide that Romulus is able to understand his role in life: on a trip to Ireland with his mentor Father Tim, he arrives near Elsie's birthplace and has several powerful spiritual experiences of reckoning. Romulus soon understands what Elsie knew all along, "that nothing can be escaped, that the past is contained in the present as well as the future" and 
he accepts "the grave responsibility of acknowledging the entwined force of the dead and of the living as they co-inhabit space" (318).

Ultimately The Loneliness of Angels professes the connectivity of all things, from human atrocities during the Great Famine of Ireland to the dehumanization of the Slave Trade, from the lwas of Haitian Vodou to the archangels of Judaism. Elsie is the synecdoche of these congruous contradictions: both in and out of time, both ancestor and contemporary guide, Elsie is also Ezili Le Flambo, patron saint of motherless daughters, the Vodou lwa whose name Ruth takes up in honour of Rose, the journalist Coco, and also her niece Catherine. Catherine, the pianist who will finally, after Ruth's murder, accept the burden of her inheritance as her generation's leader, healer, and empath, is the contemporary messiah-figure who Elsie hoped for and who Ruth was charged with protecting. After returning to Haiti for Ruth's burial, Catherine undergoes several harrowing experiences until she finally comes to understand the nature of her gift and her responsibility: "I see two lines of light surround Marie-France, one white and blue, the other dark red and black, two lines fighting each other. I, to my surprise, know what to do [...] I understand for the very first time that my hands have held the secret all along. I have just been playing the wrong instrument" (265). Her hands, trained to play Chopin, were actually always meant for the work of healing; Catherine is able to untangle the lines of light surrounding Marie-France and restore her cousin to health. ${ }^{48}$

In The Loneliness of Angels, the role of the empath and also the priest is to witness the experiences of suffering others and work to heal them. Rose lives through decades of visitations by ghosts or people tortured and killed by the Duvalier regime; she cannot cope with the burden of the ghosts' traumatic experiences, and eventually she 
ends her life in order to escape her work. Similarly, the spirits he communes with drive Lucas mad. Even Ruth intuits her own death; although she knows it is part of a greater plan, she too gives her life to the gift and to the part she must play in enacting the prophecy. Each of these protagonists struggles to endure the burden of witnessing another person's suffering: often, each undergoes this secondary trauma alone, without support. The act of bearing witness results in a wounding for the witness, the wound of "a trauma inflicted by the other's story" (Simon and Eppert 54), which Emmanuel Levinas refers to as the "traumatism of astonishment," that is, "the experience of something absolutely foreign, which may call what I know and how I know into question" (Levinas qtd. in Simon and Eppert 54). What the characters experience involves an acceptance of the limits of bearing ethical witness. And yet this effort permits the characters to model "a community of memory" (61) engaged in different types of engaged, maroon witnessing. As with the speakers in Inventory and ZONG!, the maroon witnesses in The Loneliness of Angels are physically and emotionally affected by the witnessing they undertake, indicating that the temporal and physical distance of their position nevertheless permits an intimate, ethical engagement.

$* * *$

In both Chair piment and The Loneliness of Angels, spirituality and spiritual awareness can be a burden, and witnessing can be so demanding as to become intolerable. Rose cannot withstand the trauma of being an empath for the victims and survivors of the Duvalier regime; similarly Bénédicte cannot overthrow the hundreds of ancient demons who follow her. But as is clear with Mina and Victor, as well as Ruth, her 
father, and eventually Catherine and Romulus, spirituality can also save an individual: it can be a refuge and maroonage, a paradise from slavery. A vodou perspective allows for the co-existence of the living and the dead, just as it allows for the co-existence of le Bien and le Mal along with influences from Catholicism, Judaism, and indigenous religions. The capaciousness of vodou culture makes possible the layering of histories, cultures, and religious practices that recall the past and inform the contemporary Caribbean moment. From spiritual loss leading to mental illness and zombification in Chair piment, to the invocations of prophetic witness and suffering in The Loneliness of Angels, a vodou perspective, more so than the designation of postcolonial gothic, urgently reveals the need to pay attention to the legacy of slavery from a Caribbean perspective.

In the conclusion to The Loneliness of Angels, Romulus travels to Ireland with Father Tim and there is renamed Peter. ${ }^{49}$ During his time in Ireland he gains great empathy for the thousands of Irish who starved during the horrific potato famine and who endured indentured labour under the colonial rule of the English. He is overcome with emotion when he finds himself at a road-side monument that commemorates the death of several hundred Irish. At this physical poto-mitan, he learns that victims of the famine walked twelve miles in the snow to beg for food at their master's house but were turned away. In contemporary times, an annual commemorative walk takes place: "Every year the walk is walked, remembered. Forgiveness, Romulus-Peter understands, is not about forgetting, it is about taking responsibility for the dead" (321). Romulus-Peter's newfound compassion reveals his understanding of a shared humanity and a shared struggle between all people, whether they be Irish peasants or African slaves.

With this revelation, and with the grief that floods out of him at the monument, 
causing the passersby to wonder if he too is Irish--so profound do they find his keening-Romulus-Peter finally understands what Elsie had tried to teach him all along, and he "hears only the cry of the dead and the song of the angels intermingling over the dust, rising up, granting him absolution" (322). Romulus-Peter's ability to bear ethical witness to the suffering of people from several hundred years ago means that he accepts what Simon refers to as "the summons to witness past events that are beyond one's memory and in which one has not been directly implicated" (93). The act of bearing witness, and the impact it has on him, leads to an exceptional re-adjustment of time and space that Richard A. Cohen describes as a "new time":

Witnessing, then, is an event of two disjunctive temporalities, an event in which the other's time disrupts mine. Thus, it is a new time, an extraordinary disjuncture of other and I, an experience of proximity that initiates an 'infinite distance without distance' (Cohen, 147). It is a moral time, a time of non-indifference of one person to another, of obligation and responsibility to, and for, the other. (Cohen qtd. in Simon 93)

Here again the relation between ethics and genre asserts itself; just as Elsie watches over her twentieth-century charges from a moment in the past, and just as Ruth feels a connection to her African ancestors, Romulus-Peter's weeping is possible because his empathy disturbs the limits of time and space. He is emotionally and temporally broken up by his recognition of connection, and the people on the road assume that he must have Irish blood if he is that overwrought. The act of maroon witness, because it involves dissent and distance, also breaks these limits and allows for action, whether or not that action is physical or, as in Inventory and ZONG!, contemplative poetic engagement. 
This chapter's vodouist reading of Chair piment and The Loneliness of Angels aims to underscore the significance of a transcultural and spiritual approach to Caribbean literature. These novels also implicitly underscore the ethnic and cultural complexity of the Caribbean: the mixed-race protagonists engage in multi-cultural spiritual traditions including Haitian Vodou, Catholicism, and Judaism, and thus the novels stand in counterpoint to Afro-Caribbean expectations about the Caribbean diaspora. Especially in the case of The Loneliness of Angels, a pan-Antillean vodou is revealed to contribute to an open, inclusive cultural worldview that engenders productive possibilities for imagining a multi-ethnic, poly-religious Caribbean society that honours the divergent origins of the region's peoples.

\footnotetext{
Notes

${ }^{1}$ Oral history and culture provide the most revealing examples for links between Vodou, maroon communities, and resistance. In an article about the significance of Vodou music, Gerdès Fleurant writes that the Vodou songs "of the Kongo-Petwo rite, to an extent, reflect the historical complexities of the plantation system and the imperatives of the struggle for liberation from slavery. The songs of the KongoPetwo rite have their roots in the social organization of the Maroon societies, the precursors of the bizango, the secret societies of present-day Haiti. Their roots also lie in the Bwa Kayiman (Bois-Caïman) ceremony of August 14, 1791, a starting point in the struggle which led to the Independence of Haiti in 1804" (53).

${ }^{2}$ Vodou and its related syncretic religions have been variously accepted or repressed across the Caribbean region. In 2003, Haitian Vodou was officially recognized as a legitimate religion in Haiti. In Cuba, Santería, like all religions, was banned in 1959 with the introduction of Communism; the right to practice a religion was reinstated in 2013 .

3 Paravasani-Gebert's "Colonial and Postcolonial Gothic: The Caribbean" discusses the colonial "invasion" that forever changed British Gothic literature: "By the 1790s Gothic writers were quick to realize that Britain's growing empire could prove a vast source of frightening 'others' who would, as replacements for villainous Italian antiheroes in Walpole or Radcliffe, bring freshness and variety to the genre. With the inclusion of the colonial, a new sort of darkness--of race, land-scape, erotic desire and despair--enters the Gothic genre" (229). Subsequently gothic literature developed an interest in reifying and protecting Englishness from "the attendant horror of interracial sexuality" and reflected "English anxieties that stem from the fluctuations of colonial power, the need to foster and simultaneously control black physical strength, the ever-threatening possibility of slave rebellion, and the potential spread of anticolonial, antimonarchical ideologies in British-held territories in Africa, Asia, and the Caribbean" (230).

${ }^{4}$ Key texts in the discussion about secularism and post-secularism include philosopher Charles Taylor's $A$ Secular Age (2007), anthropologist Talal Asad's Genealogies of Religion (1993) and Formations of the Secular: Christianity, Islam, Modernity (2003), Saba Mahmood's Politics of Piety: The Islamic Revival and the Feminist Project 2005, Michael Warner's The Evangelical Public Sphere in Eighteenth-Century America, Tracy Fessenden's Culture and Redemption: Religion, The Secular, and American Literature
} 
(2007), and the collection Is Critique Secular? Blasphemy, Injury, and Free Speech edited by Judith Butler, Mahmood, Asad, and Wendy Brown.

${ }^{5}$ Asad explains that rather than being a natural fulfillment of civilization, "modernity is a project--or rather, a series of interlinked projects--that certain people in power seek to achieve" (13). Asad explains that the experiences generated by the project of modernity involve a "disenchantment" that excises "myth, magic, and the sacred" in order to supposedly achieve "a direct access to reality" (13). This "salient feature of the modern epoch" bears a direct link to reading practices of the nineteenth century and to the turn to "reading imaginative literature--being enclosed within it and by it--so that images of a "pre-modern" past acquire in retrospect a quality of enchantment" (13-14). Asad argues that "we should look, therefore, at the politics of national progress--including the politics of secularism--that flow from the multifaceted concept of modernity exemplified by "the West" (and especially by America as its leader and most advanced exemplar)" (15). Importantly he also suggests turning the question on its head: "What politics are promoted by the notion that the world is not divided into modern and nonmodern, into West and non-West? What practical options are opened up or closed by the notion that the world has no significant binary features, that it is, on the contrary, divided into overlapping, fragmented cultures, hybrid selves, continuously dissolving and emerging social states [...]" (15).

6 "Elle était devant moi, la tête inclinée sur le côté. Avec sa chemise de nuit en feu, ses nattes enflammées [...] J'ai crié. Et je suis tombée par terre. J'ai dû m'évanouir" (77). All translations throughout this chapter are my own work, unless otherwise indicated.

7 “' $<$ Je ne veux plus te voir. Tu es méchante! Tu es un démon! [...] Va-t'en! Va-t'en, Rosalia! Retourne en enfer! $>$ Disant cela, Mina étreignit la croix qu'elle avait au cou. $<$ Disparais! Va-t'en! Ô mon Dieu! Faites qu'elle s'en aille! Mon Dieu, préservez-moi des esprits mauvais, Seigneur, éloignez de moi les anges du Mal. Ô Dieu des Cieux, Vous qui régnez sur la terre, chassez de ma vie le fantôme de ma soeur.>" (84-85).

8 "Dans les jours qui suivirent, la Rose fit des allers et retours entre son monde et celui d'ici. Puis réapparut avec constance, certains après-midi, toujours quand sa sœur se trouvait au lit avec un homme" (15).

9 “Ça la prenait, comme ça, comme une fièvre. À ces moments-là, elle ne gouvernait plus son corps. Elle consommait du sexe, le sexe dressé des hommes. En redemandait. En rêvait parfois ... Fallait qu'elle soit prise, possédée, traversée ... Parfois, elle entrait dans des périodes d'eaux calmes [...] Et puis, un jour, elle avait beau se mépriser et résister, la danse d'amour macabre la reprenait" (18).

10 "Des gens lui parlaient dans ses rêves, l'accusaient d'avoir mis le feu de ses mains, de descendre d'une lignée maudite, d'être responsable de la mort de sa sœur. Ses nuits étaient peuplées de créatures qui cherchaient à l'assassiner. Visions de cases en flammes et de bananeraies flambées. Ballets d'esprits tourmentés en errance sur la terre, serpents verts étrangleurs" (24).

11 "la machine folle [...] danse d'amour macabre" (18).

12 "Tout naturellement, Mina chercha solution auprès des gens de métier qui fréquentent et collaborent avec les esprits du Mal et du Bien. Prit rendez-vous chez Sarah Pitagor, une Martiniquaise medium et devineresse" (15).

13 "Sarah fournit sept prières merveilleuses à réciter quarante fois chaque dimanche à six heures, deux fioles anti-zombies contenant une eau jaunâtre d'odeur alcaline et trois poudres sucrées à disperser sur les lieux des apparitions matin, midi et soir, en veillant bien à ne pas confondre la poudre d'escampette du soir avec celle du matin, afin de ne pas mettre en transe d'incontrôlables éléments." (17)

14 “Eh bien, ma belle, continua-t-elle, faudra bien que tu finisses par voir, que tu le veuilles ou pas!” (17).

15 "Un grand Blanc aux cheveux fous, le regard d'un possédé avec ses yeux jaunis par les forces sataniques" (153). 
16 "les démons rappliquaient. Ils étaient partout. Faces immondes, ils revenaient lui tourner autour, lui souffler des insultes à l'oreille, lui parler à la télé ou à la radio, lui dicter des ordres [...]Bien sûr, elle tentait de résister. Mais chacun sait que le Mal est plus fort que le Bien” (101).

17 “Mais il n’y avait rien à entreprendre, l'affaire était trop ancienne, les démons trop enracinés” (102).

18 “pareils à des gardes de corps" (102).

19 “Bénédicte l'avait mis en garde, comme elle l'aurait fait pour n’importe quel nègre.” (153)

20 “ $<$ Tu peux être sauvé. N'écoute pas les charlatans! Je peux te sauver! JE LE PEUX! Il faut me croire! Je les vois comme je te vois. Trois démons qui te laissent pas en paix depuis ta naissance. Souviens-toi de Jésus-Christ!>“ (107).

21 “ $<$ Je dirai la Vérité et tu trembleras! [...]. La vie ne meurt jamais, jamais, jamais! Ils sont tous là, ensemble, vivants et morts! Moi j’ai des yeux pour voir, un nez pour les sentir, des oreilles pour les entendre! Aveugles! Vous êtes une bande d'aveugles!>“(106).

${ }^{22}$ Duff distinguishes between "une folie 'terminale' destructrice qui mène à la mort spirituelle (Wide Sargasso Sea, La Mulatresse solitude, Cajou, Juletane, The Bluest Eye) et une folie 'transitoire' créatrice qui, par contre, n'est qu'un état temporaire, permettant un renouvellement spirituel (Tituba, Pluie et vent sur Télumée Miracle, Praisesong for the Widow)" (138).

${ }^{23}$ For more information about vodou's similarities and contrasts with western African religious practices and its development during the era of slavery, as well as more information on the translation of the "mortvivant" into the zombie, please see Maximilien Laroche, "Mythe africain et mythe antillais: le personnage du zombi," Revue canadienne des études africaines.

24 [la zombification] “est tenue par le vaudouisant comme la punition suprême, car elle ramène l'individu à la condition d'esclave, contre laquelle, précisément, le vaudou s'est élaboré” (Hurbon qtd. in Duff 44).

25 “'L'histoire de la colonisation est celle d'un processus de 'zombification' généralisée de l'homme" (Depestre qtd. in Duff 45).

26 “'[c]'est aussi l'histoire de la quête d'un sel revitalisant, capable de restituer à l'homme l'usage de son imagination et de sa culture" (Depestre qtd. in Duff 45).

27 “'Le sel, symbole de la nourriture spirituelle, est alors l'agent du réveil des 'facultés créatrices' [...] L'être dézombifié connait une profonde libération en ce que le physique, le spirituel, et l'intellectuel regagnent contact" (45).

28 “À sa place se trouvent des personnages qui détiennent les clefs de leur propre dézombification” (121).

29 “En fait, l'aînée des Montério ne cessait de se battre avec les fantômes du passé et les anges qu'elle n'avait pu enfanter" (53).

30 "le pavillon de pierres qui symbolisait leur réussite" (24).

31 "Trois vieilles tours effarées taillées dans le béton. Cinq barres dressées entre des arbres maigres. Et six cubes couverts de tags ... les appartements, cages à poules et clapiers à lapins, où vivaient les familles ... la cité hésitait entre ruine et loques. Si on avait du temps à tuer, on pouvait se mettre à compter les carreaux cassés, les fenêtres pendantes, les voilages grisâtres ... Ou bien le linge au vent. Jeans et pulls, draps et torchons qui flottaient comme des drapeaux sans nation [...] Les bennes débordant d'immondices et de rats affairés. Parfois, les sales gamins les pourchassaient ... Les grand frères couraient auprès d'autres 
monstres, d'autres chimères, des ballons d'or, des enveloppes d'herbe" (21).

32 “Je n'ai pas vécu une enfance antillaise sous les tropiques. J'ai connu la cité ...” (Githire, 79).

${ }^{33}$ Brinda Mehta describes the experience of Antillean people in France: "Treated as migrants, foreigners, or immigrants rather than as legitimate French citizens, these diasporic subjects experience the tensions of diaspora in tenuous bonds of unbelonging between the Métropôle and the Caribbean colony, even as they creolize national space through cultural interventions, labour production, and their physical presence" (Notions 17). In interviews as well as in her own writing, Pineau has described her personal childhood experiences of racism, and the characters in her books endure a similar marginalization.

34 "Des T-shirts et des shorts que Lysia - elle avait des yeux pour voir-n'achetait pas à ses propres enfants. Ceux-là, qui roulaient les $r$ et prenaient des airs, se pavanaient dans des habits de marques américaines [...] C'était son tribut, son devoir minimal, son visa de négropolitaine aussi" (116-117).

${ }^{35}$ Pineau describes her own childhood in Paris along the same ambivalent lines: "when I was in France, people rejected me because of my black skin; when I arrived in the Antilles, I was also rejected because I was a 'Negropolitan': This Guadeloupian woman is black, but she speaks very bad Creole, rolling her 'r's. So, I was never at the right time, never at the right place, always a misfit" (Loichot 335). Here I would also like to gesture to an increasingly vibrant sub-field of "francophonie" literature within the Francophone tradition, termed littérature de banlieu, that reflects and responds to the experience of living in the French suburbs.

36 "Ils venaient de partout et de n'importe où ... Des amers en exil, soûlés de nostalgie" (23).

${ }^{37}$ In Chair piment, Lysia decides that the best she can do is give her children every opportunity for a successful future in France. At great expense considering her salary as a school-cafeteria employee, Lysia hires a tutor to teach English to her daughters, in exchange for room and board, so that they have at least one advantage when competing with their French peers. Ironically, the English tutor is a diasporic, mixedrace student from Île Maurice, who interestingly minimizes her dual Réunion/Mauritian background in favour of her Mauritian heritage, preferring to take pride in Île Maurice's independence from France rather than Réunion's dependence. Île Maurice, also known as "la République de Maurice" or "The Republic of Mauritius," has an interesting history marked by both French and English colonization; it is currently mostly English-speaking but, because it used to be a French-colony, it remains part of the cultural and political Francophonie. In Chair piment the tutor's vindication of her Mauritian identity reflects pride in its independence; like Martinique and Guadeloupe, Réunion remains part of the DOM-TOM designation and therefore under the administration of France. Whereas Martinique and Guadeloupe are "départements d'outre-mer," Réunion is a "territoire d'outre mer." Moreover, Île Maurice and Réunion have mostly mixedrace populations, where mixed-race heritage is the norm, not a rare occurrence. Réunion and Île Maurice owe the racial and cultural mixing of their populations to initial exploration by Arab sailors, various waves of European control (Dutch, Portuguese, French, British), importation of slaves from Africa, indentured labour from the Indian subcontinent and Malaysia, migration and trade with Asia, and settlement from Europe, with the result that the societies are deeply mixed and diasporic. Apparently, neither island was inhabited by indigenous peoples at the time of initial Arab and European contact.

38 "La plupart des gens attendaient la fin du cauchemar et cherchaient à tout instant une porte de sortie ... ils avaient le sentiment d'être engeôlés là, piétinés par la vie. Sur le qui-vive, en état d'alerte permanente, certains semblaient poursuivis par des esprits malins de la même trempe que ceux de Mina" (22).

${ }^{39}$ Françoise Naudillon writes about the correlation between the black female body and the tomb/grave, a Bakhtinian perspective she links to Freud and his deathly reading of the "black continent." Interestingly, Naudillon also underlines the connection of this grave-like belly with the similarly sinister core, or belly, of the slave ships. 
40 "Ce sont les femmes elles-mêmes qui assureront pour leurs compagnes le nécessaire travail de réparation du corps et de l'esprit. Femmes relais, femmes médiatrices, fontaines d'un savoir inépuisable, elles seront les garantes du temps et de l'histoire, en inventoriant les lignées féminines, comme elles seront les garantes de la communauté culturelle, voire les gardiennes de l'humanité dans son ensemble" (Naudillon 84).

${ }^{41}$ Naudillon writes that the typical grandmother, "the old, sterile woman, robbed by slavery of an erotic or maternal body, regains all her power [...] [As a] a guiding and mentoring spirit, Man Ya joins Ma Tine, the other mythic grandmother evoked by Joseph Zobel in La rue Cases-Nègres, guardian of the 'great mystery of the world,' she is the link between life and knowledge" (Julia 15 qtd. in Naudillon 84).

${ }^{42}$ Long recognized as the family's devoted friend, in fact the only "relative" Mina has left in Piment, Suzon is in fact the person responsible for the family's misery over decades and decades. Her punishment for abominable acts of black magic is that she slowly goes incurably blind. When she visits Berlus, a medicine man, he tells her she is doomed and that her punishment does not even suffice for the wrongs she has committed: "You could live another thousand years and give a thousand apologies, Mignard. Two thousand years and you would still owe more and forever. / Tu pourras vivre mille ans et dire mille pardons, Mignard. Deux mille ans et tu devras encore et toujours" (157). Berlus' pronouncement of endless penance is as epic as the love story that precipitated it. When they were children, Melchior and Suzon were inseparable. As teenagers they fell in love, and they lost their virginity to each other. Although Melchior promises eternal love and marriage to Suzon, he suddenly turns from her, taking with him his affection, promises, and even friendship. Soon after, he meets Marie-Perle, falls in love immediately, and marries her after three days. Suzon is inconsolable. After recovering from a bout of intense depression and anxiety during which she moves "zombie-like" through town at the mercy of the conflicting forces of "Le Bien" and "Le Mal" (166), Suzon begins to have a series of prophetic dreams about the many children she and Melchior could have, and she determines to dedicate her life to getting him back. But when his affections do not return to her, and when he marries Marie-Perle and has his first child Olga, Suzon begins a lengthy negotiation with spiritual and supernatural forces. She consults fifty-four gadèzafè healers and, when their methods do not work, she consults the first of ten sorcerers who work with Black Magic, thus commencing her interaction with demons, devils, and horrors.

43 "La démoniaque [...] La chienne aux crocs jaunes [...] La sorcière qui visita cinquante-quatre gadèzafè et dix sorciers afin de voir triompher l'Amour. L'immonde qui convoqua les esprits mauvais des eaux, bloqua les freins d'un camion Titan, héla la folie, la foudre et le feu. La scélérate qui pria pour que les malheurs s'abattent sur le morne Calvaire. La bête-longue qui habita le corps de la mal-aimée Suzon [...] La femmecrocodile $[. .$.$] La vieille poltronne, qui, vingt et un ans après son dernier crime, craignait d'ouvrir la lettre$ de Mina" (174-175).

44 "En 1978, Suzon lui arracha un bail de vingt ans de malédictions sur les descendants de Melchior" (176).

45 “ $<$ La noirceur a ratissé large et pour longtemps, sans frein ni amarre. Elle a proliféré pareille à une plante mauvaise qui étouffe et dévore tout sur son passage. Quand elle n'a plus trouvé de chair à manger, elle s'est tournée vers toi qui l'avais commandée. Vers toi, comme un chien affamé s'attaque à son maître. Le mal n'est pas repu ... Qu'est-ce que je peux faire contre ces puissances que tu as toi-même déchainées?"“ (156).

${ }^{46}$ Casteel's Calypso Jews provides an in-depth study of the Caribbean as refuge for Sephardic and later Mizrahi and Ashkenazi Jewry.

${ }^{47}$ In classical history, Romulus and Remus were the twin sons of the god Mars and Rhea Silvia, a vestal virgin. The brothers were raised by a surrogate mother, a she-wolf, and after they were grown they eventually built a settlement on Palatine Hill. After a quarrel, Romulus killed his brother and renamed the settlement Rome, after himself. To populate the new town, he invited disenfranchised people to settle there, including exiles, refugees, and slaves. 
${ }^{48}$ In Vodou mythology, the colours blue, white, and pink relate to the loa Erzulie Freda Dahomey when she is in the Rada aspect, and the colours red and black relate to Erzulie when she is in the harsher and warriorlike Petro aspect. Red and black, in Vodou, generally relate to power, and these colours are also associated with the loa Kalfou (Carrefour), who is Papa Legba's twin brother. Like Papa Legba, Kalfou controls the crossroads, but unlike his brother, Kalfou is more interested in dark spirits, black magic, and sorcery; the relationship between Papa Legba and Kalfou underscores Vodou's understanding of balance. Additionally, red and black are the colours associated with the secret societies of Vodou.

${ }^{49}$ Romulus's new name is also significant. In The New Testament, Peter was a disciple of Jesus along with his brother Andrew. His original name is Simon, or Simeon, and Jesus renames him Peter, rock, after Simon declares that Jesus is the Messiah and the Son of God: "Blessed art thou, Simon Bar-Jona, for flesh and blood has not revealed this to thee, but my Father in heaven. And I say to thee, thou art Peter, and upon this rock I will build my Church, and the gates of hell shall not prevail against it. And I will give thee the keys of the kingdom of heaven [...]" (Holy Bible, Papal Edition, Matt. 16. 17-19). Importantly, Peter is also an example of a forgiven sinner who is the recipient of Jesus's admonition "oh ye of little faith" (17. 18-20). 


\section{Chapter Three}

\section{The Maroon Bildungsroman and the Work of Dangerous Memory in Edwidge Danticat's The Dew Breaker and Jan J. Dominique's Mémoire d'une amnésique}

This chapter centers on Jan J. Dominique's Mémoire d'une amnésique (1984), a novel/memoir that is obstinately both fiction and fact, and Edwidge Danticat's The Dew Breaker (2004) which can be read either as a novel or as a collection of short stories. The two books in many ways are Bildungsromane, and yet they are not traditional novels of development nor are they necessarily novels at all: the books are puzzles, and in each the narrative shifts perspective, location, time, and style. The formal innovations of these books reveal their relation to the poetics of maroon witnessing discussed throughout this dissertation. In fact, the radical formal innovations as well as their representation of what I call dangerous memory underscores the significance of Danticat's and Dominique's texts and their contribution to the maroon project of disturbing the status quo, promoting the blurring of race and genre categories, and rebelling against legacies of colonialism. The books' formal ambiguity also reveals one of human rights literature's most taboo topics: that is, the lacunae of perpetrator memory and what Erica Bouris refers to as issues related to "complex political victims." This chapter unites postcolonial Caribbean frameworks with attention to human rights-inflected scholarship and reveals a distinctly Caribbean bildungsroman genre preoccupied with maroonage, memory, and artistic development.

The traditional bildungsroman, along with the closely related Künstlerroman, developed during the European Enlightenment and can be translated from the German as a novel about the formation, upbringing, or education of an individual, usually male, and 
his integration into society ("Bildungsroman" Dictionary of Literary Terms and Literary Theory 81-82). Traditionally the term "refers to a novel which is an account of the youthful development of a hero or heroine (usually the former)" and "describes the processes by which maturity is achieved through the various ups and downs of life" $(82){ }^{2}$ The genre's origins are "grounded in western European notions of development and the values of reason, wholeness, and progress [...] that underlie modes of justification for colonialist practice" (Smyth 181), and therefore the genre is related to the ideologies that also led to modernity, imperialism, and the slave trade, as Joseph Slaughter elaborates on in Human Rights Inc. Indeed, Franco Moretti writes that the bildungsroman is "the 'symbolic form' of modernity" (5). Interestingly, "the genre is widely used in the Caribbean by both male and female writers" (Smyth 181). The veritable "proliferation" (181) of such texts by Caribbean writers can be seen either as an anomaly or as indicative, perhaps, of an oppositional stance of generic resistance "to challenge European systems of knowledge and ways of understanding subjectivity and collectivity that characterize colonial discourse" (182). Heather Smyth defines the Caribbean bildungsroman as "a Creolized, mixed, and adapted form" that, because it "looks backward as well as forward [...] is obsessed with origins" (182). The Dew Breaker and Memoire d'une amnésique likewise contribute to a counter-discursive project of generic resistance and, with their attention to human rights concerns, perpetrator testimony, and fragmentation, also reveal a Caribbean bildungsroman of maroon witness. ${ }^{4}$

The Dew Breaker demonstrates ambiguity in form as well as content. In terms of language, Danticat writes in English but her words are propelled by the rhythm of Haitian Kreyol cadence, storytelling, and word games. The book's title character is also unusual: 
both larger than life and elusive, the Dew Breaker actually occupies a small part in the physical action of the stories. And yet his presence looms over the lives of the characters, who are each linked, unbeknownst to them, because they are survivors of his actions as a tonton macoute. The stories in The Dew Breaker expose the horrors of life under the Papa Doc and Baby Doc Duvalier regimes by unraveling a family secret: the truth that a respected Haitian man living in Brooklyn had been the "hunter" and "not the prey" (The Dew Breaker 21). Danticat's sympathetic portrait of the former macoute M. Bienaimé, along with his daughter Ka's artistic development and emotional struggle to understand her father and his wife Anne's conflicted loyalties, offers a dissident contribution to debates about memory and postmemory (Marianne Hirsch) within the Künstlerroman sub-genre, victimhood and perpetrator-hood, and the delicate work demanded of transitional justice.

In Mémoire d'une amnésique, the narrative voice switches as frequently as does the protagonist's first name. Like Danticat, Dominique also engages with the framework of the bildungsroman to present the narrative of her alter-ego Paul-Lili. The book, "written" by Paul-Lili, traces the "protagonist's" childhood in Haiti during the Duvalier regime and her eventual immigration to and adulthood in Montreal, followed by her return to Haiti twelve years later. With an emphasis on the perils of forgetting, Dominique's account questions the truth possible in a memoir, the reliability of narrators, and the authority of "History." Despite her desire to forget terrible events, ultimately memory seeps into the mind of Paul-Lili / Dominique and compels her to write. Like The Dew Breaker, Mémoire d'une amnésique is about struggling with trauma, interacting with perpetrators including the omni-present "l'homme en noir," Duvalier himself, and the 
challenging work of dangerous, critical memory.

The controversy about perpetrator memory exemplifies the tension in memory studies about which testimonies are valuable, legitimized, sanctioned, and which are not. The often elusive "figure" of the perpetrator nevertheless inhabits all survivor narratives in some way, and I am interested in the embodied omnipresence of this figure and its lasting effect on survivors. Danticat's and Dominique's bildungsromane present portraits of families in which the lines are blurry at best between perpetrator, complex political victim, and survivor. The content and formal innovations of the two works, although decades apart in publication, directly address the ambiguity and paradoxes surrounding the figure of the perpetrator in human rights and memory studies and contribute to the unique efforts of maroon artists to intervene in the political life of Haiti, its diaspora, and in unofficial processes of transitional justice.

This chapter's attention to human rights-inflected literary criticism reveals in The Dew Breaker and Mémoire d'une amnésique the insidious potential of what I call “dangerous memory," a term that recalls Danticat's mission for immigrant artists to "create dangerously." Dangerous memory involves critical remembrance that can, many years later, destabilize a person, a family, a society, and even a diasporic community. In this case, the books reveal several uncomfortable truths: first, that exiled perpetrators can sometimes live with impunity alongside survivors in the diaspora; second, that perpetrators and survivors cannot always prevent the aftermath of trauma from affecting their close relations; and third, that the opacite and ambiguous identity of the mixed-race subject is often a troubling legacy of colonialism and the slave trade. A human-rights approach to Caribbean literature underscores how this legacy lives alongside the critical 
celebration and denigration of métissage, créolisation, and hybridity.

\section{Art, Myth, and the Künstlerroman in The Dew Breaker}

Within the continuum of alternative maroon narratives discussed throughout this dissertation, Danticat portrays non-violent dissidents in works such as 1994's Breath, Eyes, Memory and Brother, I'm Dying, her 2007 memoir and twin biography of her uncle Joseph and her father Mira. The author's poetics of maroon-witness are notable in thematic choices, in character development, and in self-referential strategies that together argue for the power of the imagination to, as she puts it, "create dangerously." To create dangerously, for Danticat, "is also to create fearlessly, boldly embracing the public and private terrors that would silence us, then bravely moving forward even when it feels as though we are chasing or being chased by ghosts" (Create Dangerously 148).

Throughout her multi-genre oeuvre, whether or not the work of dissident critique involves confronting political or familial history, the protagonists in Danticat's fiction enact strategies of maroon-like dissidence that offer alternatives to the conventional model of the maroon as male hero. Further, the artistry that the protagonists engage in possibilities for working through trauma and living in traumatized societies.

I focus here on The Dew Breaker (2004), in which Danticat presents perhaps her most unconventional revision of the Caribbean maroon narrative. This cycle of linked short stories exposes the horrors of life under the Duvalier regimes by unraveling a family secret: the truth that a respected Haitian man had been "the hunter" and "not the prey" (The Dew Breaker 21). In The Dew Breaker's opening story "The Book of the Dead," Ka learns that her beloved father was a perpetrator, a tonton-macoute, a para- 
military torturer and supporter of the Duvalier regime. In the book's short stories Danticat explores the acts of violence that this perpetrator committed: each story features characters who were "the Dew Breaker's" victims, or connected to his victims, and who are therefore survivors of the violence he inflicted as a macoute.

Interestingly, The Dew Breaker portrays how national myths can be co-opted by the oppressor, and makes links between the figure of the maroon and folkloric and historical Haitian characters. Papa Doc Duvalier, for instance, was famous for his sinister self-characterization as Baron Samedi, or Baron Cimetière, the Vodou loa in charge of death and therefore the guardian of the graveyards; Duvalier's twinning with Baron Samedi underscores the cultural significance of Caribbean folklore within Haitian politics. What happens when the national myth of a masculine maroon hero transforms perversely into the dark shadow of a tonton-macoute, feared as a robber of children, harbinger of death, and breaker of the peaceful dew? Just as The Dew Breaker responds to Haitian folk stories, it also responds to a seminal text of Caribbean and Haitian literature, Masters of the Dew by Jacques Roumain, first published in French as Gouverneurs de la rosée (1944). ${ }^{5}$ Sixty years later, Danticat's text displaces Roumain's ultimately hopeful view of Haiti with the realization of a bitter present. Roumain's title invokes "le gouvène roze," the Haitian Kreyol expression for the peasant who is in charge of irrigating and cultivating his lands but also, symbolically, who is in charge of his own destiny (Tabti 342). On the other hand, Danticat's novel refers to the tonton macoutes who were often called "shouket laroze," disturbers of the dew, because they came before dawn and disturbed the peace: in Danticat's own words, dew breaker "really means somebody who breaks or shakes the dew" (Danticat qtd. in Tabti 342). In essence then, a 
dew breaker prevents the Haitian people from becoming or remaining the masters of their dawn, their land, their nation, and their lives.

Reactionaries and subversives in their own way, tonton macoutes are nevertheless opposed to the maroon in the cultural imaginary: responsible for enslaving the people rather than fighting for their freedom from oppression, they prevent Haitians from being "gouverneurs" of their nation. In this way the macoute can be seen as a grotesque inversion of the maroon trope, a sinister caricature of an extreme revolutionary who poisons the land and enslaves the people. ${ }^{6}$ It is worth noting that Roumain's novel traces a physical journey across the Haitian landscape in search of a water source and a spiritual source. Like the protagonist in Glissant's novel La Lézarde who descends from the mountains of Martinique to the plains, the protagonist in Gouverneurs de la rosée journeys across the land and in so doing gains in self-awareness. In The Dew Breaker, a statue of M. Bienaimé is thrown into a lake, and this gesture precipitates, for $\mathrm{Ka}$ and her father, a perilous internal maroonage that eventually liberates them and leads them towards their own truths.

Significantly, Danticat's novel overthrows Gouverneurs de la rosée's optimistic conclusion. The Dew Breaker "carries the burden of the island's recent suffering and heralds that wounding and destruction at the novel's opening" (Tabti 343). ${ }^{7}$ The contemporary violence that fragments the novel into nine narratives also resonates with a sense of political danger and conflict that goes beyond Haiti. In addition to paying homage to such Caribbean precursors as Roumain, Danticat chooses an epigraph to the novel by the Russian poet Osip Mandelstam: "Maybe this is the beginning of madness ... / Forgive me for what I am saying. / Read it ... quietly, quietly." ${ }^{8}$ Danticat's reference and 
invocation of Mandelstam speaks to her engagement with dissident art and to the potential of transnational affinities between diasporic subjects, internal exiles, and migrants. While Gouverneurs de la rosée is "the narrative of a return in which exile becomes the space of consciousness-raising and awareness" (Tabti 348), in Danticat's novel "we stay in exile" (348). ${ }^{9}$ Danticat's sense of the artist's political responsibility to create what she or he believes in, no matter the state's political leaders or its suffocating breakers of the dew, is the raison d'être of Create Dangerously and of The Dew Breaker.

But how to create dangerously, and why might bearing witness and sharing testimony through art be considered the work of dangerous memory? In The Dew Breaker, Danticat boldly portrays perpetrators as well as victims and underscores how trauma has become endemic to Haiti. The focus on and the at-times sympathetic portrait of a perpetrator adds another layer of complexity to the problem of representation without doing further harm. Moreover, the stance of witnessing presented in the figure of Ka exemplifies that of the maroon witness: from her position inside America but outside Haiti, and simultaneously connected to Haitian culture rather than American culture, Ka is a perpetual outsider whose distance allows her to see objectively and to respond creatively, and dangerously, to her father's perpetrator testimony.

Whereas most scholarly works in both French and English literary criticism have so far focused on the story entitled "Night Talkers," ${ }^{10}$ my reading is concerned with the members of the Bienaimé family who are featured in "The Book of the Dead," "The Book of Miracles," and the title story, "The Dew Breaker." Set in Tampa Florida, Brooklyn NY, and Port-au-Prince Haiti, the stories are presented in reverse chronological order to reveal the Bienaimé family's secrets. By focusing on these three stories, I 
interrogate the role of $\mathrm{Ka}$ as an artist figure and witness to both her father's perpetrator testimony and her mother's role as a complex political victim. The first story, "The Book of the Dead," introduces Ka and her gentle father, 65-year old M. Bienaimé, who is never given a first name. The two have driven from their home in Brooklyn to Florida so that Ka can sell one of her wooden sculptures. The intended buyer is a famous HaitianAmerican television star, and Ka's father has come along to meet her. On the day of the intended sale, Ka awakens in their hotel room to find both her father and her sculpture missing.

Ka's artistic work is motivated by her father; she finds endless inspiration in his elusive nature, in his humility, and in his past as a political prisoner: "I'm really not an artist," thinks Ka to herself, "not in the way I'd like to be. I'm more of an obsessive wood-carver with a single subject thus far--my father" (The Dew Breaker 4). Ka is especially intrigued by her father's past, and she works out her questions through her art: "I had never tried to tell my father's story in words before now, but my first completed sculpture of him was the reason for our trip [...] it was my favourite of all my attempted representations of my father. It was the way I had imagined him in prison" (6). Rendered in the novel through the technique of ekphrasis, Ka attempts to express her father through sculpture. His portrait is not possible through other means, because M. Bienaimé cannot stand to have his photograph taken; his excuse is that he feels embarrassed about his scar. Ka thinks that his scar is a sign of his suffering, his victimhood, and his survival, and her sculpture reflects her desire to pay homage in some way to his "regal and humble" story" (11). Their family name, after all, means "well-liked," and Ka sees her father as a good man who has suffered bravely. 
The truth of M. Bienaimé's past is brought to light after he disappears with Ka's sculpture and throws it into a nearby lake. He returns to the hotel many hours later to explain to Ka that he "[doesn't] deserve a statue [...] not a whole one, at least." "You see, Ka," he confesses, "your father was the hunter, he was not the prey" (20). Significantly, it is Ka's artistic work that motivates M. Bienaimé to finally confess to his daughter, and thus thirty years of silence, disguise, and deceit evaporate due to the humility and humanity he sees in the sculpture but that he cannot recognize in himself. He admits to her for the first time that he was never a prisoner in Haiti: "I was working in the prison $[\ldots]$ It was one of the prisoners inside the prison who cut my face in this way [...] This man who cut my face [...] I shot and killed him, like I killed many people" (21-22). By revealing this perpetrator testimony, Ka's father unwinds the lies he has neatly spun and protected over the years. Ka begins to doubt him, and also to doubt the role of her mother: "Was she huntress or prey? A thirty-year-plus disciple of my father's coercive persuasion?" (22). "Manman, how do you love him?" (24) begs Ka when they are speaking on the phone. The Dew Breaker's stories reveal the web of suffering M. Bienaimé has created, a net that reflects Haiti's long-term stranglehold of oppression. M. Bienaimé, it turns out, was responsible even for the death of his wife's brother, and it was he who gave M. Bienaimé his scar. ${ }^{11}$

For Ka, her relationship with her father is intrinsically bound up with her experience as an artist. Her artistic development and transformation is narrated in the book; the traditional Künstlerroman is "a novel which has an artist (in any creative art) as the central character and which shows the development of the artist from childhood to maturity and later" (Dictionary of Literary Terms and Literary Theory 446$).{ }^{12}$ Yet here 
the traditional Künstlerroman genre is in tension with trauma, testimony, and the burden of witnessing, because Ka's development depends on her father's innocence or guilt, both of which in turn motivate her art. When she describes how her perception of her father has changed since his confession, she can only turn to the modality of sculpture. Rather than responding to the humility and dignity she associated with him before, she sees him suddenly as duplicitous and dangerous: "If I were sculpting him at this moment, I would carve a praying mantis, crouching motionless, seeming to pray, while actually waiting to strike" (26). Ka's evolving understanding reveals how the process of witnessing does not end after the eye-witness, survivor, or perpetrator has shared his or her testimony with the secondary witness; instead, the circuit continues so that the testimony is shared and shared again, until social behaviour is influenced and adjusted based on that testimony. Ka undertakes the "practice of commemorative ethics" that Simon advances vis à vis survivor testimonies (56); this practice requires her to "respond" to her father's perpetrator testimony "with acts of acknowledgment, remembrance, and an indication that hearing another's testimony has been consequential" (56). By imagining her father in a new pose, that of the prone, praying mantis, Ka responds to her father's testimony. His portrait is no longer that of a humble hero but rather it shows the two faces of a complex, intimate perpetrator. Moreover, Ka's new artistic rendering of her father also reveals her own experience of bearing maroon witness to his testimony.

At this juncture I wish to underline the importance of scholarship that engages specifically with the relationship between art, testimony, and witnessing and that recognizes how representational acts play a role "in testifying to historical atrocity and the power of the aesthetic as a response to collective horror" (Goldberg Beyond Terror 
25). Goldberg reads the plot and structure of Danticat's earlier novel The Farming of Bones "as a function of the urgent need to testify" (160). In that novel the representational mode is storytelling, and the fictional survivors of the historic 1937 Rivière Massacre genocide share their stories to ward off death and suffering: in Danticat's words, "the haste in their voices [was] sometimes blurring the words, for greater than their desire to be heard was the hunger to tell" (The Farming of Bones 209). Similarly to the examples of literature of atrocity and extremity that the dissertation has already examined, such as ZONG! and Inventory, The Dew Breaker reveals the fragmentation of a narrative that cannot be told and a form that is always inadequate for the telling.

Jill Bennett explores the formal properties and artistic strategies of visual art in order to discover "what art itself might tell us about the lived experience and memory of trauma" (2), an intervention that dovetails with my investigation of Ka's visual art and her role as an artist figure. Initially, Ka's art is motivated by her need to understand her parents' elusiveness; after her father's confession, her art changes as she struggles to express and deal with the truth of his testimony. "Whereas artists are reluctant to pin down meaning - and hence to concede that a given work is about trauma," nevertheless it is possible "to identify the way the work operates within a political field" (14). For my reading of Ka's work, what is important is the "dynamic process of intervention: a specific mode of engagement" (14) on the part of the artist and hopefully later in the spectators who view the art. Dori Laub writes that "[Holocaust] survivors did not only need to survive so that they could tell their stories; they also needed to tell their stories in order to survive" (63). Similar impulses are experienced by children of survivors of 
trauma and by children of perpetrators of war crimes; known also as the "second generation," they too are compelled by postmemory to speak or write about their parents' experiences as a way to deal with their secondary trauma.

Regardless of the content, the visual work produced by the artists Bennett discusses, the testimonies Laub studies, or the artistic work that the fictional Ka undertakes "[make] a particular kind of contribution to thought, and to politics specifically" (Bennett 21) and "[invite] an awareness of different modes of inhabitation" (12). Overall the artists each contribute to the debate about what and who is worth remembering and commemorating. Danticat's representation of a perpetrator and his family raises many more questions than it answers for public memory, contemporary war tribunals, and reconciliation processes. In terms of specifically perpetrator testimony, the witness has to choose a response that, often, involves a choice between indictment or amnesty for the perpetrator. Whether or not the fictional Bienaimé family can be seen as an example of the complexity of Haitian society, perhaps transitional societies need to follow Anne Bienaimé's words and accept that life might never stop being on "a pendulum between forgiveness and regret" (The Dew Breaker 86). Bearing witness involves enduring the "psychic burden" of history, transporting and sharing the traumatic stories with others and, finally, allowing that remembrance of past injustice to influence the witness and inform his or her actions in the present. What one does with the testimony is part of the process of ethical remembrance — and it is through that attentive ethical response and those "forms of critical inquiry" (Bennett 10) that witnessing can have a socially transformative or galvanizing potential. 


\section{Postmemory and Perpetrator Memory in The Dew Breaker}

Ka's artistic preoccupation with understanding her parents' silence accords with the motivation of many children of survivors and victims of atrocity, war, and trauma who try to express or pay respect to their parents' story of suffering. Hirsch theorizes this preoccupation as a consequence of "postmemory," the relation of children and descendants to the traumatic events experienced by their parents or ancestors. Postmemory is an intergenerational memory or connection that links survivors with nonsurvivors and enables the transmission of stories and histories: it is "a structure of interand trans-generational transmission of traumatic knowledge and experience. It is a consequence of traumatic recall but (unlike post-traumatic stress disorder) at a generational remove" ("Generation of Postmemory" 106). As a parallel concept within the context of the African Diaspora and post-slavery narratives, Toni Morrison famously articulates the phenomenon of "rememory" in Beloved.

Children of survivors, like Ka, can take on the role of a distanced or mediated witness as part of their experience of postmemory; although the trauma they tell is not their own trauma, they feel responsible for or compelled to keep the story in circulation. In The Dew Breaker, Ka becomes an artist so that she can process and tell her family's ambiguous story. She describes herself as being from Haiti, even though she has never been there, but in truth she is in cultural and physical exile from her pays. She is deeply connected to a country she only knows through her reticent parents and through her own imagination. Like the maroon, she is both inside and outside of her society, and she looks towards Haiti from America and from across a wide distance. For Ka and for others of the postmemory generation, creating a life for themselves and finding belonging can be 
challenging. In the case of Haiti in particular, with its seemingly endless experience of oppressive regimes, as well as its history of censorship, postmemory can be experienced as a dangerous burden. Postmemory involves "a particular end-of-century / turn-ofcentury moment of looking backward rather than ahead, and of defining the present in relation to a troubled past rather than initiating new paradigms [...] it reflects an uneasy oscillation between continuity and rupture" (106). I posit that dangerous memory is a possible consequence of postmemory, and that it can re-traumatize survivors, perpetrators, and "complex political victims" (Bouris) with its revelation.

As a child of the "second generation" or "the postmemory generation," $\mathrm{Ka}$ is obsessed with understanding her father: consequently, his elusiveness, instead of the stories or memories he could have shared with her, makes up her principle obsession. When his daughter was born he insisted on naming her Ka because in Egyptian mythology "a ka is a double of the body [...] the body's companion through life and after life. It guides the body through the kingdom of the dead" (The Dew Breaker 17). As her father explains, "ka is like soul [...] In Haiti is what we call good angel, ti bon anj. When you born, I look at your face, I think, here is my ka, my good angel” (17). Indeed, with her birth came his own rebirth or resurrection--it was then that he was able to tell his wife the full truth about his past, and together they made a commitment to keep hiding that truth, even from their daughter. But the father's past influences the daughter's present, and she cannot shake the persistence of his memories. In this way Ka's filial duty is to accompany her father in his secret; this, her terrible inheritance, is one of the burdens of the postmemory generation.

Hirsch's account of postmemory is critical to my argument for a rapprochement 
of human rights studies, trauma studies, and Caribbean literature. Indeed, it is possible to see the empathic and emotional links between the postmemory generation and fictional characters such as Ka. It is also worth pausing over the significance that Hirsch places on the role and responsibility of the witness to trauma. Caribbean literature, with its many testimonial novels, first-person narratives, and works of creative non-fiction, is a literary corpus that tends to privilege the voice of the witness. Despite the persuasive links between postmemory and "rememory," there has been reticence in relating Caribbean literature to the theoretical gains that witness theory has made in North American, Latin American, and European academia because of ostensibly imperialist, colonial, European associations and issues. Additionally, post-slavery novels and Toni Morrison's concept of "rememory," for instance, are usually embraced as exclusively African-American experiences of trauma. Although rooted in an attempt to legitimize and empower AfricanAmerican writers, this flattening out can nevertheless be limiting for the multi-ethnic and multi-racial Caribbean experience. Instead, I contend that a human-rights inflected scholarship can help to encourage cross-diasporic alliances around trauma and survival. For example, Édouard Glissant's promotion of an Antillean consciousness and an attitude of multi-relation intersects with Michael Rothberg's concept of "multidirectional memory" which attempts to erase the boundaries built by "competitive memory" and instead bring different histories of trauma into relation with one another. This expansive critical movement, I argue, reaches outside the political boundaries entrenched by colonial policies and encourages transnational conversation across groups of people. A decolonizing trauma theory can take into serious consideration the experience of diasporic and exilic subjects who, despite their physical location in a foreign land, 
nevertheless are part of the identity and experience of their home country, and who may or may not be doubly fragmented by their mixed-race identities and multi-ethnic heritage.

While Ka inherits the legacy of her perpetrator father, it must be recognized that her mother is, in Bouris's words, a "complex political victim" and herself a survivor of trauma. Yet Anne Bienaimé chooses to support her husband in his dissembling, and after thirty years she maintains a fervent faith in his redemption, in "the simple miracle of her husband's transformation" (73). When Ka thinks she has spotted the notorious Haitian torturer Emmanuel “Toto” Constant at their church's Christmas Mass, Anne wonders how she herself would react if it were, indeed, the famous torturer: "What if it were Constant? What would [Anne] do? Would she spit in his face or embrace him, acknowledging a kinship of shame and guilt that she'd inherited by marrying her husband?” (81). Whereas Ka feels rage and indignation towards this man she thinks is Toto Constant, Anne's reaction is more ambivalent and revelatory of the relationship of kinship between perpetrator and complex victim. She fears that her husband too might be recognized one day, and she is concerned about the "righteous displeasure" Ka displays at the mass (80). "But what if she ever found out about her own father," worries Anne, "About the things he had done?" (80). Until her husband confesses to Ka about his identity, Anne continues to live with worry, "her life a pendulum between forgiveness and regret" (86), although she is resolved nevertheless to maintain the terrible secret.

The linked stories in The Dew Breaker can be seen as a self-referential artistic offering on Ka's part to share the traumatic history of her family, since each narrative details the long-term suffering of the victims of the Duvalier dictatorship. The book culminates in the title story "The Dew Breaker," which is set furthest back in time and 
which reveals how Ka's parents met on the night of her father's last murder. The novel's temporal reversal encourages the reader to develop a sympathetic portrait of M.

Bienaimé. Although his testimony comes in the first story, it is not until the book's final story, "The Dew Breaker," that the narrator reveals the reasons for his joining the macoutes: the power, privilege, and notoriety he gained as a result; the fear he inspired; and the delight he felt when engaging in violence. In short, the final story reveals him at his most brutal. However, because it follows the sympathetic portraits of M. Bienaimé as a family-man and loving father, it also paradoxically reveals his vulnerability, his lack of choices, and his humanity. The order of the stories, like Ka's nuanced future sculpture, disturbs expectations and shows the perpetrator to be a complex, multifaceted figure.

Danticat does not make obvious the key to the book's structure. Does Ka narrate the book as an attempt to put together the truth about her father's life? Or are the stories narrated by an omniscient narrator whose reflections are unavailable to her? Alternately, since the act of testifying can be healing for the victim, as represented in Danticat's The Farming of Bones as well as in the work of trauma critics including Dori Laub, Shoshana Felman, and Cathy Caruth, is it possible that one of M. Bienaimé's victims or survivors is narrating the book? As the reader comes to understand the connections between the characters and the events, he or she becomes a witness to the truth and therefore becomes obligated to respond. Danticat throws obstacles in the way of easy understanding; negotiating the turns and puzzles in her text requires focused engagement on the part of the reader and reminds him or her of the considerable effort and heavy burden demanded by testifying, witnessing, and grieving. The very difficulty of the reader's experience of the text parallels the obstacles facing the maroon witness whose complex process of 
engagement involves collusion and participation as well as defiant rebellion.

Although Ka does not learn the full extent of the truth in the first story, "The Book of the Dead," she does try to understand and respond to her father's testimony and to the suffering he has caused. Remembering his obsession with Egyptian mythology and especially the rituals of judgment before death, Ka begins to ask nuanced questions about responsibility, guilt, and forgiveness, questions that are at the heart of human rights discourse about reconciliation, redress, and transitional justice. When Ka's father assures her that he would "never do these things now" (24), she believes him and takes comfort in his words: "It was my first inkling," she says, "that maybe my father was wrong in his own representation of his former life, that maybe his past offered more choices than being either hunter or prey" (24). With these words, Ka reveals her interest in thinking beyond the traditional divide between victim and perpetrator, and she begins to wonder if these categories are inadequate since a man like her father cannot be entirely good or entirely evil, nor can a perpetrator be judged outside of the society in which he comes from - in this case, a generally traumatized society.

Ka's interest in her father's complexity, rather than simply his complicity, disturbs normative portraits of victims and perpetrators. Her questions, which reveal the ambiguity between perpetrator-hood and the experiences of complex political victims and survivors, in addition to the new sculpture she begins to imagine, are radically dissident and unusual, and Danticat's advancement of these ideas in her novel contributes to "the fairly recent emergence of perpetrator voices" within academic and political circles (Dunnage 91). The reasons for this emergence include "war crimes trials since the 1990s" which "paradoxically $[\ldots]$ have often provided [perpetrators] with a platform from which 
to 'talk back' to their victims, many of whom are no longer alive to defend themselves" (91). Interestingly, it is often the descendants of perpetrators who sympathize with, protect, or "who publicly defend their cause today" (91). As a second-generation "heir" to her father's acts, the moment of transmission during which Ka hears the truth from her father is the moment she becomes implicated in his guilt. However, this is also the moment she becomes empowered by his testimony and begins to question all manner of binaries.

Danticat's response to this vexed debate is truly radical because her portrait of $\mathrm{M}$. Bienaimé is sympathetic. Most interventions in academic discourse and cultural initiatives are organized according to "victim-perpetrator/ good-evil absolutes [that] fail to take account of the rather more blurred dynamics behind oppressive state rule and acts of atrocity" (Dunnage 91). In contrast, Ka is aware that her father has suffered in his own way as a result of his crimes, which have also afflicted his wife and daughter with guilt, paranoia, and shame. His prison nightmares and his continual fear of discovery have had an impact on each of their lives. Without minimizing his guilt, Ka reaches for an understanding that "[tries] for a way between vengeance and forgiveness" (Minow 4). In understanding the impact of her father's actions not only on his victims but also on himself, Ka alludes to the expansive reach of suffering in Haiti and the limitations of traditional forms of retributive and restorative justice, especially when rebuilding societies in which victims and perpetrators will live together. In contrast to Ka, critic Dominick LaCapra hesitates to extend sympathy, empathy, identification, or victimhood to perpetrators of trauma. In any conversation about perpetrators, the issue of understanding and compassion is obviously vexed. 
But how can there be reconciliation in the fictional world of The Dew Breaker, and how can Ka feel compassion if the perpetrator in question does not apologize or attempt to reach out to the survivors and families of his victims? In the non-literary world, human rights activists and scholars tend to agree that, even if an apology is not accepted, it must first be given genuinely as a first step towards reconciliation, redress, and social or individual healing. Despite his confession to Ka, M. Bienaimé never apologizes. Importantly, he is also never forced to be accountable. In the story "Night Talkers," Dani realizes that it is his Brooklyn landlord, M. Bienaimé, who is responsible for his parents' assassination in Haiti years ago. Dani does not confront him but instead returns to Haiti to mourn and reflect. Here too the ambivalent nature of maroonage is at play; Ka, Anne, and Dani accommodate and collude with M. Bienaimé in order to protect their safety but also to protect his identity. And yet this collusion is only fleeting since the truth of M. Bienaimé's actions reveal themselves in Ka's art and in the nightmares that cause Dani to cry out in his sleep. Nevertheless the legacy of M. Bienaimé's guilt, including bearing witness to his confession, falls on his daughter and on Dani, both second-generation survivors of his crimes, who are tasked with carrying the burden of the dangerous memory.

Interestingly, much as M. Bienaime's secrecy motivates Ka's art, his complicity cripples him. His long deceit, enigmatic life, and his history full of lies, shadows, and holes, inters him in a suffocating half-life. As Ka explains, he only "came alive" during their weekly visits to the Brooklyn Museum's exhibit on Ancient Egypt. Perhaps it is here that his regret and guilt find expression; he can only reflect on the death he inflicted on others by dwelling on the ancient, long-dead Egyptians. He especially admires the 
rituals described in The Egyptian Book of the Dead about "the way they mourn their dead. 'They know how to grieve,' he'd say, marveling at the mummification process" (The Dew Breaker 12-13). Ka's art, her father's reverence for the ancient Egyptians and their death practices, the maroon experience, and Danticat's writing itself, relate in some way to grief and grieving. Whether or not what is grieved is lost innocence, past lives, violent acts, even countries, the acts of witnessing in Danticat's The Dew Breaker testify to lost lives and, more generally, to loss. Writers like Danticat seem to maintain that there is "something to be gained from grieving, from tarrying with grief" (Butler "Violence, Mourning, Politics" 30), acknowledging that there may be a benefit gained by dwelling in the reality of trauma, death, atrocity, and injustice rather than sending out armies, acknowledging that there are more active and humane ways to respond to injustice and human rights violations. What might this "something" be and what might be its potential? Danticat's characters, and her writing in general, attempt to pay homage to both the living and the lost. And yet, what memorial strategies exist to help survivors and perpetrators to live together? In transitional societies, coexistence is unbearably challenging. ${ }^{13}$

In the case of The Dew Breaker, Ka's sculpture of her father's ambivalent past prompts his confession, and her ongoing work with mourning and memory leads her to reflect on her father's life and confront the layers of suppression that are part of Haiti's traumatic past. In “The Book of the Dead,” M. Bienaimé notes that when she was younger Ka was always most interested in the missing pieces of the Egyptian statues and relics, in what was not there (19). Later, she is able to admit that her art is about trying to represent her idealized father, a man who is not there. In her fascination with negative space and with representing the impossible, Ka's work is like other works of poetry and 
literature associated with trauma, atrocity, and testimony, literature that is often "fragmented [...] shattered, exploded, or splintered [...] itself traumatized" (Against Forgetting 42). Motivated perhaps instinctively by the missing parts of her father's story, Ka's artwork highlights the holes in her familial and national histories, and her individual Bildung or maturation is possible only because of the confrontation with her father's testimony. From her position as a maroon witness inside/outside Haiti and inside/outside the U.S., she rebels against her family's masks of denial, probes their secrets, and creates work that succeeds in making the complex truth visible. Ka's coming to traumatic knowledge is an experience of unmasking, an immersion in uncertainty and ambivalence that is in tension with the progress of a traditional bildungsromane. Ka is a witness to what is said and what is unsaid, to the nuances between victim and perpetrator, to the pain of the hunter and the pain of the prey. Her art, like Danticat's writing, enacts the revolutionary politics it itself witnesses, and generates a complex, defiant critique of posttrauma societies, traditional bildungsromane, and easy divisions between victims and perpetrators.

\section{Formal Innovation, Trauma, and Fragmentation in Mémoire d'une Amnésique}

In 1984 Jan J. Dominique's Mémoire d'une amnésique was published by Deschamps in Port-au-Prince Haiti. Referred to as a "récit" on the title page, this work was the author's first publication at the age of 31 , by which point she had already immigrated to Montreal and then returned to Haiti, her place of birth. The title of the book translates into English as both "Memory of an Amnesiac" and "Memoir of an Amnesiac," although significantly the book's translator Irline François chooses the latter 
for the 2005 and 2008 English publications. ${ }^{14}$ The title's dual nature is telling both of the book's thematic and structural ambiguity, as well as of its project of dangerous memory and its relation to maroon witness poetics. Author Jan J. Dominique is the daughter of famous Haitian radio journalist Jean Dominique, who founded Haiti's first Kreyol radio network, Radio Haïti-Inter, and who was an avid political critic throughout his life. ${ }^{15}$ Dominique père was frequently imprisoned, threatened, and exiled twice by Duvalier's forces; he was murdered on April 3rd 2000 by unknown assassins who have never been brought to justice. ${ }^{16}$ In 2003, a few years after her father's death, Dominique returned to Montreal where she currently lives and writes. Her works are concerned with the concepts of memory, writing, exile, Haitian women, and family.

The protagonist of Mémoire d'une amnésique bears two names: Lili, and Paul, after her father, and in part the book involves the negotiation of her dual yet fractured identity. The protagonist's contested identity reveals a preoccupation with formal and thematic fragmentation, and while the protagonist's fractured identity is in conflict with the traditional narrative progression of the bildungsroman, nevertheless it is in line with the legacy of colonialism and Caribbean identity politics. In her analysis of Mémoire d'une amnésique, François reads the excavation of memory as the strategy that allows the protagonist to eventually "transcend" the traumatic historical events and legacy of Duvalier's dictatorship and to, eventually, return triumphantly to Haiti:

Most of the novel is written in non-linear form and is 'a-chronological,' a form which echoes the act of remembrance itself. Together, theme and structure expose the socio-political reality of Haiti under the Duvalier regime from 1957 to 1971. Indeed, Dominique's narrative structure emphasizes the protagonist's will to 
'rearrange' this reality, and ultimately to transcend it. (287-288)

However, François' reading goes too far in privileging the protagonist's relation to historical time by not carefully considering the protagonist's personal journey or recognizing the importance of ambiguity in the book. As I will demonstrate in this section of the chapter, Dominique's text is not a traditional bildungsroman but a genrebending, politically subversive literary work that testifies to the importance of developing, for the author and the protagonist, a maroon-witness self-reflexivity that responds to but is not consumed by trauma, historical events, and the opacité of race and genre.

Despite the book's relation to the bildungsroman, Dominique's work struggles against the linear, forward-moving confines of that tradition. The early pages of the text are a synecdoche for the whole project, in that they move swiftly across different genres, narrative voices, temporal registers, and spatial modes. The book's prologue describes the 1934 departure from Haiti of the American marines, known as the Yankees, after 19 years of occupation. This departure is told from the perspective of a young boy who is the protagonist's father, Paul Sr., who in 1934 is six years old; as its place in the prologue makes clear, this historical departure takes on the power of an Ur incident for the narrator, her father, and by extension Haitian society.

Mémoire d'une amnésique also refuses the simplicity of a standard and consistent narrative voice. Marie-Agnès Sourieau explains that the book presents two completely different narrative modes: "The author describes the project as having two narrative arcs; the text of the book alternates between two different and opposing narrative systems" (697, translation mine). ${ }^{17}$ The first narrative mode is typeset in italics and is written in the 
present tense. This mode consists of diary entries, letters signed by Paul, and commentaries or anecdotes recounted by Paul-Lili's Haitian friends and acquaintances in Montreal, and all of these texts are narrated in the first person. The second narrative mode of the book is written in the past tense and with an omniscient, third person narrative voice. In these writings, the text is typeset in Roman Type and recounts episodes in the life of Paul-Lili and her family members, including her 6 year old father in 1934, and snapshots of life in Haiti in general. Sourieau argues that the book as a whole is propelled by the techniques of opposition and that it seeks to reconcile these tensions through the process of recovering memory (697).$^{18}$ Although I do not fully agree with Sourieau's reading of Paul-Lili's search for closure and repair in the book, nevertheless I find interesting her observation about the techniques of opposition. Sourieau sees in Mémoire d'une amnésique the use of "techniques" and "tactics," in line with de Certeau's understanding of those terms, in order for the protagonist and the author to write herself into Haitian History, to "subvert the repression imposed by the patriarchal ideology and thus to assert herself as a woman in a newly reclaimed space" $(696) \cdot{ }^{19}$

The original book jacket to the 1984 edition is rich with extra-textual meaning. The cover includes two frames and two accompanying biographical notes. The first frame shows a photograph of Dominique, and the biographical note reads as follows: "Her, that's J.J., the author. She is 31 years old and as far back as she can remember, she has always written. Because she likes to write, and because she needs to write. Mémoire d'une amnésique is her first publication. Other texts exist, and they will be published later, if she can!" (Dominique). ${ }^{20}$ Below this photo and caption is an empty, blank picture 
frame bearing this caption: "The other, that's Paul, the narrator. She is 33 years old. She writes. Because she likes to write, and because she needs to. Mémoire d'une amnésique will likely be her only publication." ${ }^{21}$ The book jacket's extra-textual evidence is what supports my reading of the narrator as Paul-Lili rather than as simply Lili. Any other naming practice contradicts her struggle of coming to accept her complex identity as a maroon-witness, a diasporic subject and, as I will show below, as a person of mixed-race heritage, in spite of society's perceptions and definitions. Moreover, ignoring the duality of the author-narrator does a dishonor to the genre-bending, anti-categorization mission of Mémoire d'une amnésique, as well as to the protagonist's significant personal fragmentation.

Kathleen Balutansky understands the design of the book jacket as further proof of the "authenticity" of Lili and simultaneously of the "tenuous" divide between the two narrators:

At the outset, then, Dominique sets up her own genealogical poetics: the empty photo frame suggests both Lili's state of absence as the story begins and the strong resemblance to Dominique that surfaces as Lili emerges in the course of the novel. In this extra-textual link, Dominique reinforces her connection to Lili; as they attempt to write their way out of a circumscribing patriarchal space, Dominique is the image in whom Lili can find herself beyond the text's oedipal narrative. (37)

And yet while Balutansky's observations about Dominique's slippery relation to Lili are sound, her comments disregard the significance of the use of the name Paul in the book jacket's caption, other than as reinforcing Lili's "relationship to her father through his 
name [which] mirrors the author's own position vis-à-vis her father" (37). For Balutansky, for the protagonist to "exist at all, to become gendered (female) as Lili (that is, to overcome her <lack> of memory (18)," she must "[stop] defining herself through her father and [find] a positive identification not only within the narrative itself, but beyond it as well, in her resemblance to J.J." (37). Thus in this reading, the protagonist's struggle is one of asserting female identity within a patriarchal context. And yet, though neither Balutansky nor François refer to the protagonist as anything other than Lili, I read the protagonist's struggle for self-assertion not as a struggle with the patriarchy but rather as a struggle to accept contradiction, complexity, and paradox.

From the first instance of textual signification, the book plays with ambiguity and ambivalence: even the title deserves attention. As Dominique herself explains in a 1991 interview, "I tried with the title to suggest this contradiction between wanting to talk about this period and the very difficulty in doing so" (Sourieau 702). ${ }^{22}$ Dominique's assertion of the difficult and challenging "space of contradiction" underscores the role of ambiguity and ambivalence in the book. If Mémoire d'une amnésique is a fictional bildungsroman, then what of the biographical parallels between Dominique and her “fictional" protagonist/narrator? How does one read the eponymous echoes of Jan J. / Gigi Dominique, named for her father Jean, and Paul-Lili, named for her father Paul? ${ }^{23}$ Moreover if the book is a novel, why would Paul be granted a head-shot, albeit blank, and an author bio, albeit ironic, on the book's back cover?

Of note here is the fact that neither Balutansky nor Sourieau refer once to Dominique's mixed-race heritage, which is tangled up with the book's thematic and formal promotion of ambiguity and opacité. Paul-Lili too is mixed-race, and her quest for 
her writing voice is also a quest for a sense of self. The experience of dangerous memory, like that of being mixed-race, leaks out when it is not supposed to and refuses categories. The truth of miscegenation is something that itself can be considered a dangerous memory. Both lauded and feared during the era of the plantation and the larger colonial period, the mixed-race subject has a complex history and place in the contemporary Caribbean. Often, the mixed-raced subject is defined by others according to a set of limiting categories, rather than being allowed the opportunity to define him or herself.

Although the trope of the "Tragic Mulatto" is in some ways mainstream, scholarly discussions of mixed-race identity other than according to the somewhat flattening phenomenon of creolization are less common, despite literary examples that contend with mixed-race figures, including texts by Rhys, Walcott, Cliff, Chamoiseau, Espinet, and McWatt. The lack of critical attention might be the result of a certain Afro-Caribbean discursive dominance as part of a cultural backlash to the legacy of European colonialism. Alternatives to this preoccupation include recent discussions of dougla identity, referring to the mixed identity of people of East Indian and African heritage. Brinda Mehta theorizes the "dougla imaginary" and "kala pani discourse" to underscore the importance of this identity category, despite mainstream preoccupations with European or African ancestry and a general devaluation of the Indian presence in the Caribbean. A literary “dougla imaginary [...] acknowledges the presence of two Caribbean Middle Passages, both African and Indian" and is "a site of enabling cultural possibilities" (Notions 9). Mehta writes of dougla identity as a "third space," inspired by Homi Bhabha, that is "the very space of Caribbean diasporic positionality, a medium to give voice to the Indo-Caribbean experience" (146). 
In Mémoire d'une amnésique, Paul-Lili's struggle to define herself relates to her ethnicity and race as well as to her double name; in some cases throughout her life she is too black and in others too white, in some contexts she is not black enough and in others not white enough. When she was growing up, her father Paul insisted that colour should not matter: "Paul always told the little girls, when looking at images from the fourcorners of the globe, that everyone was equal. With regards to choosing friends, it did not matter whether her skin colour was more or less brown, black, or green, or whether she had a lot of dresses and new clothes or gold earrings. He only refused the sons and daughters of croquemitaine [...]" (Dominique 94). ${ }^{24}$ However in Montreal Paul-Lili is the victim of an act of overt racism by her neighbours: "How could I possibly have lived in this country for so long without certain rejections?" (94). ${ }^{25}$ She also endures more casual, uncomfortable curiosity including questions such as "why your hair, why your skin, why your words?" (94). ${ }^{26}$ Although called "the pretty foreigner" rather than usually the recipient of intense aggressions, Paul-Lili nevertheless "saw [herself] as other in every display window despite not hearing the insults" (95). ${ }^{27}$ Because she is mixed-race, PaulLili has always been circumscribed and categorized by others in her life. Her need to write is a need to define herself according to her own standards; the narrative that results, with its various and shifting voices and perspectives, temporal modes, and oppositions, represents and celebrates the complexity of mixed-race identity in the Caribbean and in the diaspora, and the tension that always reveals itself between culture and race.

The bildungsroman genre is traditionally associated with the reification of nationhood as well as selfhood. Étienne Balibar discusses the use of social institutions such as the family and schools in order to invent a national people and write a national 
narrative; similarly, Cheah writes in Spectral Nationality that "the successful working of civic patriotism depends on national Bildung understood not as ideological indoctrination, but as a cultivational process where universal ideals are incarnated in the daily practices of a collective's individual members" (8). And yet Moretti reads the bildungsroman as "the most bastard" and "impure" of genres (10), and Smyth surmises that "perhaps in some surprising ways [it is] a genre capable of contradiction and heterogeneity and kin therefore to Creolization" (190). In her article about the feminist bildungsroman, Smyth discusses the Belizean novel Beka Lamb and argues for the correlation between the protagonist's individual awareness and her country's national culture: "Beka Lamb makes this link in a way that suggests that the diversity and Creolization of Belizean society, features that will affect the political shape of the new country, will also shape Beka's sense of identity" (190). Dominique's Mémoire d'une amnésique is a similarly oppositional and confrontational bildungsroman due to its sinister portrait of "l'homme en noir," of the heightened anxiety of Haitian society, and of a protagonist buffeted by cultural forces. By highlighting the voice of a mixed-race, fragmented female protagonist, Dominique uses the bildungsroman genre to comment on the past and future of Haitian society in general, and to underscore the need to look beyond traditional narratives of History and culture.

Likewise Dominique embeds key historical moments and figures within the book's narrative, and Paul-Lili both participates in and is haunted by them. One compelling example is the figure of Papa Doc Duvalier who takes on a terrifying omnipresence in the book as the figure of "l'homme en noir":

The Man in Black was someone who everyone knew but who must never be 
named; if we spoke of him, we had to be very careful to always speak highly of him; and even if this meant telling a lie, you had to be so careful as to not make an error, because no one could guess it was a lie. As a result, the little girl was taught to say nothing and to never speak. $(35)^{28}$

Paul-Lili's family and community live in fear of drawing the attention of l'homme en noir, and as a result the young protagonist's voice is physically and symbolically silenced.

The fear of attracting attention is compounded by Paul Sr.'s activities as a dissenter and harbourer of fugitives. Indeed, he himself is often imprisoned, and his own brother mysteriously disappears; consequently, Paul-Lili grows up in this fraught environment of intense dread. One day she overhears an intense political conversation among the adults: she does not understand the words, but she does not like the new stranger who is seeking refuge in their home, and so she looks at him with distaste. Suddenly, immediately, her father slaps her in the face. When he later apologizes to her, he begs her to understand his reason:

You looked at him with such hate. I saw your death. I know now that you couldn't possibly understand the meaning of our conversation. You didn't do it on purpose, you simply don't like André. But I saw, in that fraction of a second, how you could look at a croquemitaine in that same way, and that he could kill you for it. You need to be protected. Forgive me when you can. $(38)^{29}$

Because he saw in her look of suspicion the echo or seed of a look she could one day show to a croquemitaine or tonton-macoute, Paul-Lili's father became terrified for her. He slaps her out of fear but also to teach her a lesson that even the way she looks at someone could decide her fate. The slap is one of the iconic events in Paul-Lili's life: it is 
both a betrayal on the part of her father but also a symbolic sign of fear and repression. In her society, not even fathers can protect their children from Duvalier. The dictatorship has caused the corruption of every bond so that nothing is sacred anymore, and violent acts are used to prevent further violence. The slap, la gifle, remains an impossible knot in the relationship between Paul-Lili and her father and contributes to her eventual conflation of him with l'homme en noir himself.

Mémoire d'une amnésique also interacts with certain key events that shaped Dominique's generation in Haiti, and in this way it relates to what Smyth refers to as "a Caribbean women's bildungsroman that links its protagonist's development with critical political events in a nation's history" (188). This sub-genre "marks a significant intervention of Caribbean women writers" into male-dominated debates about the construction of national history and identity. One key event is the public shooting on April 26, 1963, in front of the private Swiss Methodist college L'école Bird; Dominique inserts Paul-Lili into this event by making her a pupil at this school: "the actual historic shooting was a failed attempt by Duvalier's opponents to kill two of his children who were students at the school. Instead, the driver and two bodyguards were killed. The children were unharmed" (François 291). In the scene in Mémoire d'une amnésique, Paul-Lili walks to school as usual and finds herself caught in the middle of the shootout: "There they are, in the middle of the road, in front of the school, several men kneeling behind a long black car, shooting at other men. (Who are the good guys and who are the bad guys in this anachronistic Western?)" (Dominique 53). ${ }^{30}$ After a boy pulls Paul-Lili to the ground to protect her against his body, the shooting continues until, finally, the silence takes over: "several seconds pass, or minutes, or was it hours (it felt like hours), 
and it is finally quiet, and this silence is more terrifying even than what came before" $(53) .^{31}$

Although Paul-Lili sees "the bodies lying in the middle of the road,"32 the adult narrator of the book is troubled by the uncertainty of her memory:

Had she really heard the noise? Had she heard the enormous silence? Had she really seen that boy who heard her walking into the middle of the silence? Did he really reach for her so she could lie down against him on the sidewalk? Did he keep holding her to him even when there was no more sound of bullets hitting against the walls of the school? But what happened to the bullets that didn't hit the walls? Those prayers mumbled under the benches of the classroom. Did she really pray? To God or to the Devil? (55). ${ }^{33}$

Paul-Lili's memory is fragmented by the traumatic moment. Moreover, the innocence of the little girl, already hardened by the omnipresence of l'homme en noir, has once again been violated: "She should never have known any of this. She realized later that she would never be able to forget it. But she didn't realize how deep the trace of the bullets would be in her memory. It was a time when she should have been happy and protected by innocence and naïveté" (55). ${ }^{34}$ Instead, this event becomes part of her lifelong nightmares and part of the truths she is compelled to suppress: "She would never speak about that classroom bench behind which she crouched, trembling, with the endlessly looping sound, in her ears, of the bullets that never hit the walls" $(55) .{ }^{35}$ Dominique's narration of this event reveals the sheer chaos of the society she and her protagonist grew up in-a society that suffers from the attempted murder of children in a morning shootout outside a school. 
Another historical event narrated in Mémoire d'une amnésique is a public execution that was held on November 12, 1964, in the cemetery of Port-au-Prince. Under threat of severe consequences for disobedience, the public was ordered to attend. A national holiday was decreed to facilitate massive attendance, peasants were bussed in from the villages, school teachers were required to bring their students, and the event was repeatedly re-broadcast on the television and on the radio. In total many hundreds of people were forced by Papa Doc Duvalier, Baron Samedi / Baron Cimetière himself, to watch the public execution of young dissidents Marcel Numa and Louis Drouin. In Mémoire d'une amnésique Dominique writes that Paul Sr. defied the edict: "Paul, he braved his fears, defied the law, kept his daughter at home" (64). ${ }^{36}$ And yet though she does not witness the execution, Paul-Lili remembers it: "In spite of all that, she remembers" (64). ${ }^{37}$ The public execution becomes for Paul-Lili a recurring nightmare, even though she did not witness it herself, and thus it too reflects the experience of postmemory.

The public execution is so significant that Dominique returns to it in Mémoire d'une amnésique, this time from the second-person perspective. This anecdote or text within a text describes the experience of a white tourist who comes to visit Haiti. Told in the second-person perspective and in the imperative mode, the anecdote speaks directly to the reader who is interpolated as "vous," and who easily comes to identify as a tourist who has ended up in Haiti quite by accident. In a mode of address similar to that used in Jamaica Kincaid's $A$ Small Place, the perspectives of the tourist and the reader become fused into that of a voyeur, so that the reader is implicated in the event of colonialism for Kincaid and the political turmoil in Haiti for Dominique. After following a local tour 
guide, and motivated by a search for local culture, the presumably white tourist in Mémoire d'une amnésique is led to the cemetery where he/she is thrust into the watching crowd:

You see again those groups of school-children unmistakable in their uniforms. You remember wondering 'now what are all those children doing here?' You thought, at that moment, that maybe there would be a special ceremony to honour some national personality — a celebrated writer, notable educator, or politician perhaps? When you finally reached the spot where everyone else was gathering, you did not understand the significance of the two poles set up under the sun. $(66)^{38}$

Dominique's inclusion of this anecdote directly after Paul-Lili's recollection of missing the execution, itself a memory spurned by a need to explain the relation between writing and trauma, underscores the psychological and cultural weight the public execution has on her. Despite her absence, she remembers the event as if she had been there. The $2^{\text {nd }}$-person perspective of the narration allows the reader to connect to the event from an intimate yet removed vantage-point not unlike Paul-Lili's experience of the execution from her childhood bed.

Significantly, the protagonist explains that she is haunted by each and every possible viewpoint of the execution, including that of the tourist, although it is unclear how she has insight into the minds of others: "This event is part of my regular nightmares. I am at once the dazed tourist, the smiling tour guide, and the little girl sitting frozen on her bed for the whole day. She too could have been out-he must have been crazy to keep her at home in spite of the decree. This event is part of my nightmares" $(67) \cdot{ }^{39}$ The use of 
narrative transference in Dominique's dual portrait of the execution demonstrates its tremendous cultural weight. This narrative strategy reveals the significance of postmemory, and the power of cultural memory, as well as the mythic resonance of this specific traumatic event. Danticat also writes evocatively of this same execution in Create Dangerously; although like Paul-Lili she too missed the event, she later watched film footage, and she refers to it as one of the creation myths that have influenced her development as a writer. Ultimately Dominique, Danticat, and Kincaid underline the critical role of the distanced maroon witness, and the maroon writer's compulsion to record, reveal, and transmit to the reader the events of the past, in whatever form he or she chooses.

Importantly each author also highlights the burden of witnessing. Paul-Lili admits to the physical and emotional pain she endures by being sympathetic to the pain of others, and yet she also admits to the positive motivation that trauma has had on her writing. Although she experiences the burden of witnessing, writing follows:

It hurts inside my head, it is as if I am hungry inside my head; I have endured every measure of torture inside my head, because those who are hungry, in pain, those suffering from malnutrition, illiteracy, without shoes, dressed in rags, those with highest infant mortality rate, those with a life expectancy of only forty, those executed in the public square or in anonymous silence ... ; without the daily horror of those and their struggles, why write? And yet, as you say here, there, and everywhere, you aren't actually writing for them. $(68)^{40}$

Paul-Lili describes the feeling of being overwhelmed due to her calling, even as she reveals how suspicious others may be of her motives. Yet is this selfish benefit of finding 
subjects to write about so mercenary as to be offensive? It is my contention that in Mémoire d'une amnésique the maroon-witness protagonist is already so fragmented that it is only through the act of writing that she can be made whole.

\section{“Toujours les masques!": Fragmented Narrative and Coming to Voice}

The first chapter of Mémoire d'une amnésique is written in italics, which, as mentioned above, is the type font that graphically represents the voice of the narrator. The first chapter testifies to the need for the narrator to stop censoring herself and instead to declare her true identity and intentions:

I began writing this text in the third person, in order to hide myself, and though I know this camouflage and disguise is ridiculous my fingers write 'she' when my head thinks 'I,' 'Paul,' 'Paul.' The result: writer's block! But it is not enough anyway to write 'I' so that the multiple disguises and masks that costume my characters can fall around me [...] I feel, finally, for the first time, the need to tell, to tell everything, to tell absolutely all the stories I have in my head. (11) ${ }^{41}$ This opening section is a provocation on the part of the author/narrator to finally speak her voice and declare her thoughts and stories: "I don't want to hide anything any more! I don't need to hide myself any more; I don't need to be scared anymore. Instead, I need to find a way to stop depending on these masks, these habitual masks" (11). ${ }^{42}$ The act of writing is an act of bravery, schooled as she is in being docile, well-behaved, and quiet about risky subjects: "I react as if I am still stifled from the pressure to be silent! Never speak about just anything to just anyone, you never know who you are truly dealing with. The paranoia cultivated by the instinct to survive, this attitude I have always lived with 
that I thought had finally disappeared: it returns now in a different form" $(11) \cdot{ }^{43}$ The narrator declares herself ready to throw away the masks, hide nothing, and begin the exorcism that will lead to her survival: "It's a question of survival; I can't stand being silent any longer" (11). ${ }^{44}$ The enterprise of the writing itself is made even more challenging because the author/narrator is doubly silenced since she is both a victim of social amnesia and a woman (Sourieau 694, paraphrased translation mine) ${ }^{45}$ Paul-Lili's writing project is in part a feminist project and one that involves a rejection of patriarchal society.

Balutansky argues that the protagonist, whom she refers to throughout as Lili not Paul-Lili or Paul, must break through the shadow and identity of her father Paul Sr., who symbolizes for Balutansky and Sourieau not only patriarchal domination within the family but also patriarchal domination within Haiti:

In order to write as a speaking subject in the first-person singular, Lili, the protagonist whose real name is Paul like her father's, must struggle to emerge as herself from between the two Pauls. As long as she is unable to do so, she is imprisoned within her father's identity. Wedged between Paul, the self who is the image of her father, and Paul, her father himself, Lili is traumatized into silence. (Balutansky 35).

But what of the letters signed "Paul" and the journal entry at the book's conclusion in which the narrator wonders about whether she will be Lili or Paul in Haiti after being known as Paul for so long in Montreal? Which identity is her "true," "authentic" identity? Although Balutansky, Sourieau, and François maintain it to be Lili, I argue, as does Christine Duff in Univers intimes, that rather than one or the other, Lili or Paul, her name 
and identity is instead a composite of both, and that the true, full, honest acceptance of its very opacité is the "truth" she seeks.

The development of the writing voice is a necessary struggle that is not unfamiliar to the genre of the bildungsroman, in which the protagonist matures and develops into his or her own rational, mature, and independent person; the sub-genre of the Künstlerroman traces the artistic development of the protagonist. Yet within Caribbean literature this genre of the "novel of development," despite its European heritage, is often the genre that serves as a vehicle for a writer and character to focalize a rage they feel as a result of the legacy of colonialism and the slave trade, so that the maturing adolescent must shirk off the mantle of colonialism as well as childhood. ${ }^{46}$ It is through the writing process that the character Paul-Lili "focalizes her rage," and Michelle Cliff attests to a similar experience when she explains her own journey as a writer: "After reading [Ghanaian writer Ama Ata Aidoo's book] Our Sister Killjoy, something was set loose in me, I directed rage outward rather than inward, and I was able to write [...] [I] surprised myself with the violence of my words" ("Preface: Journey into Speech" x). Like The Dew Breaker, Mémoire d'une amnésique is also a Künstlerroman that traces Paul-Lili's journey to finding her voice and becoming a writer.

This trope or concern about developing the writing voice prevails in Caribbean women's writing, and its articulation and process can be seen in the works of Kincaid, Myriam Warner-Vieyra, Jean Rhys, Cliff, and Danticat, to name but a few writers for whom this is the case. In these Caribbean women's Künstlerromane, the protagonist must write herself out of the control of her parent, often her mother, and write herself into the history of her island and the world. This phenomenon has been much discussed, 
including by Carolyn Rody in The Daughter's Return; indeed this "introspective journey" and the use of the "fictional autobiography" is "the preferred vehicle for expressing feminine / feminist / female consciousness" (Wilson qtd. in Sourieau 698).

In Human Rights Inc. Joseph Slaughter describes the "historical, formal, and ideological interdependencies" between liberal human rights discourse and the development of the genre of the bildungsroman (4), including the connection that "both human rights and the novel have been part of the engine and freight of Western colonialism and (neo) imperialism over the past two centuries" (5). Slaughter discusses "the sociohistorical cooperation and formal intersections of the Bildungsroman and human rights as extensions of the Enlightenment project to modernize, normalize, and civilize (or, perhaps better, civicize) the individual and society" as well as "the problems that such complicity creates, particularly with the Bildungsroman's ambivalent capacity to disseminate and naturalize not only the norms of human rights but also the paradoxical practices, prejudices, and exclusions codified in the law" (5). As discussed at the outset of this chapter, how does a postcolonial critic reconcile the correlation of the bildungsroman with "the engine and freight of Western colonialism" (5)? Yet as Gregory Castle writes, "the struggle with genre guarantees its survival and its relevance" (4) and thus resistance to the bildungsroman genre could in fact reinvigorate a traditional form and make something new. Many Caribbean examples of the bildungsroman are counterdiscursive and oppositional. For one, Mémoire d'une amnésique throws off the traditional mantle of the European and especially French "growing up" novel. Both a narrative of Haiti and of Montreal, the book gives a uniquely diasporic and maroon perspective to the subgenre of the Caribbean bildungsroman. Paul-Lili is compelled to "take off the masks" 
that she wears in order to excavate the truths of her identity and of her memory; this act is dangerous not only because it is an act of maturation or growing up but also because it is an act of decolonization. The protagonist finally refuses the masks forced upon her by colonialism, those white masks that hide what Fanon describes as an Antillean malaise and dependency due to the legacy of the slave trade and European imperialism. Rather than an act of adult self-actualization like in the traditional bildungsroman, Paul-Lili's mask-removal reveals her desire to throw off the legacy of slavery and unchain herself from colonial and colonized society.

And yet, perhaps, one final mask remains at the close of the novel, and that is whether or not Paul-Lili is really Jan J. (Gigi) Dominique, the author who bears a striking resemblance to the book's writer-narrator. Mémoire d'une amnésique's second chapter, entitled "La Statue Décapitée," begins in this way: “Once there was a little girl named Paul, but everyone called her Lili. Why? That is a long story" (Dominique 13). ${ }^{47}$ It is here in this chapter that the narrator explains that because the parents were disappointed not to have a son, they named their daughter Paul after her father; because of what they will explain as a clerical error, the name is somehow never feminized to Paule. Immediately afterwards, everyone begins to call the child Lili, and they intentionally forget the origin of her true name. In this way Dominique begins the third-person narrative about Paul-Lili with the question of the name, and thus the identity of the narrator, front and centre. In this way too it is clear that whatever the initial reason, from her birth Paul-Lili's identity is circumscribed by others, who prefer to always call her Lili so as not to mistake her for her father or for a boy. The text notes that "it must be admitted that it made things easier for everybody that the little girl became called Lili. Much later, when the little girl grew 
up and wanted to reclaim her true identity, everybody tried to prevent it" (13). ${ }^{48}$ PaulLili's "reconquering" or "reclaiming" of her identity is, in fact, what motivates her writing and is the purpose of the book itself. Indeed, it is during her period of exile in Montreal that Lili becomes regularly referred to by her peers as Paul, and it is at this time that she begins to write.

Interestingly François's insistence on referring to the writer-narrator as Lili undermines the protagonist's struggle, desire, indeed fight to identify herself and write her own story. The dual-naming is also the textual representation of the ambiguity and complexity which the book deals with on a thematic and structural level and which puts forward to the readers an ambiguity, complexity, and opacité that reveals the book's maroon poetics. While François argues that Lili's act of writing is her attempt "to put together the fragmented parts of her country's socio-political reality in an effort to expose, exorcise and finally come to terms with her personal and national history" as well as to restore a matrilineal heritage of female-centered stories and voices $(292,300)$, ultimately I read Mémoire d'une amnésique as a deeply ambivalent text interested in the complexity of identity, memory, and form rather than in one or another political camp, feminist or otherwise.

Although Paul-Lili does become increasingly sure of herself and more adept at writing her story, her decision to return to Haiti is not a triumphant one that "transcends" her personal struggles, as François reads it. Instead, it is during the preparations for returning to Haiti that Paul-Lili miscarries her child, the unborn Maya for whom the writing is partly intended (Dominique 168). It is also at this time that Paul-Lili's nightmares begin to blur the face of her father with the face of l'homme en noir (181), 
and it is on the metaphorical eve of departure that she begins to mourn for the community of women she has found in Montreal but which she will now lose. Finally it is upon leaving for Haiti that she realizes that she is returning to a place where everyone called her Lili, whereas for 12 years in exile she had been called Paul:

I realize suddenly that a second past was becoming clear, even as I hadn't yet finished understanding the first, Lili's past. For the past twelve years, I am and have been Paul, and so I have no idea what name will imprint itself on my skin once I step down from that plane-that plane for which those tickets, bought long ago now, wait on my writing desk. Paul lives, Lili eludes me still. -pause. (179) ${ }^{49}$

The conclusion to the book is ambivalent. While the title to François' essay is celebratory and transcendent, Paul-Lili does not so neatly journey from confinement to freedom. The book's structural ambiguities, its thematic focus on opacité and uncertain memory, and its narrative insistence on taking up identity make any categorical pronouncement seem inadequate. The last lines of Mémoire d'une amnésique are as vague as any within: "Will I be able to return to these lines one day?"50 wonders Paul-Lili, desperate suddenly not to finish the manuscript or conclude her story. She writes that she cannot find an ending because she does not know her own: "I have no idea what awaits me; I don't know what I'll find there, or what will happen to me. I only know that I'll carry these pages with me as long as I need to. For the exorcism. Tomorrow I leave. - pause?" (188). ${ }^{51}$ Most striking to me here is the adamant refusal of Mémoire d'une amnésique to close with a traditional ending. In so doing, it refuses once again its generic categorization as either memoir, novel, or chronicle of Haitian history; rather, it declares its own desire for unfettered freedom of form, of narrative voice, of source material, of plot. Like Paul- 
Lili's always evasive hold on her past, this memory, this book, is also incomplete and ultimately dangerous because of its multiple versions of truth and its insistence on a maroon-like defiance of limits.

\section{$* * *$}

In this chapter I have worked with two contemporary texts by Haitian writers that exemplify the genre of the maroon-witness Caribbean bildungsroman. This oppositional bildungsroman, closely related to the Künstlerroman subgenre, traces the ethical development of the protagonist into an artistic maroon witness and the prise de conscience she experiences that leads to the truth about her family's involvement in Haiti's political past. Truth is dangerous memory in Memoire d'une amnésique and The Dew Breaker; in both works, revelations of truth and testimony interrupt and put at risk the protagonist's stability and innocence. Yet ultimately truth allows for the protagonist's artistic evolution as a writer and a sculptor, respectively. When Paul-Lili admits that "without the daily horror of those and their struggles, why write?" (68), her confession underlines the complexity of her role as a witness and as a writer. Although the human rights paradox is about the tension between responding artistically but not doing more harm through representation, in some ways Paul-Lili's coming to voice as a result of witnessing other people's trauma demonstrates an inevitable complicity. Like Anne Bienaimé who colludes with her husband in order to protect him from punishment for his crimes, Paul-Lili is not wholly innocent nor wholly ethical in her artistic motivation. Ka too relentlessly sculpts her father's likeness in order to fulfill her own creative impulse. Not unlike the figure of the maroon who engages in collusion and cooperation with 
plantation owners, as described by Sharpe in Allegories of Empire, by James in The Maroon Narrative, as well as by Condé in I, Tituba, Black Witch of Salem, the objective and dissenting posture of the maroon is complex and nuanced.

Nevertheless, no matter how beneficial Ka and Paul-Lili find their artistic process, or perhaps because they are able to recognize the paradoxes at work within, their maturity as artists will likely benefit their families, if not their communities. Societies in periods of transitional justice can be transformed by the work of artists, especially when those artists invigorate and support community projects. Within the fictional world of The Dew Breaker, Ka's artistic work literally and figuratively creates the impetus for the revelation of M. Bienaimé's crimes, and, hopefully, a kind of rapprochement for his family, if not for his victims. The books also present a productive discursive fragmentation, suggesting the potential of broken, fragmented, ambiguous artistic form for presenting trauma testimony.

My reading of these texts, informed not only by trauma studies but also by the concept of literary maroonage, highlights the need to pay attention, respectively, to perpetrator memory as well as to mixed-race experiences when discussing human rights issues in the Caribbean and its diaspora. The oppositional bildungsroman, in the hands of Dominique and Danticat, becomes a powerful and provocative tool of testimonial transmission, as well as a portrait of the ambivalent, risk-taking, empathic maroon witness herself. Set in Montreal, Haiti, New York, and Miami, the books nevertheless spin out from a Haitian nexus concerned with the legacy of colonialism and its manifestation in the darkness of Duvalier's tyrannical regime. Ka and Paul-Lili productively approach the opacité and complexity of their family situations because of 
their maroon distance and artistic disposition. Their ability to hold empathy both for victims and perpetrators demonstrates the importance of the role of the artist figure in social transformation and, perhaps, heralds a contemporary Haitian revolution that will reckon with the wounds of the past by engaging with transformational artistic practices.

Notes

${ }^{1}$ In Complex Political Victims (2007), Erica Bouris writes that a complex political victim is one who is "no longer chained to characteristics of complete innocence and purity, but remains a victim nonetheless" and that they "may bear some discursive responsibility for her or his victimization, a victim who may have a contradictory set of 'interests' and as such would have difficulty fitting into the traditional script of the ideal victim" (10). For more about ethics, victimization, and ideal versus complex victims, please see Erica Bouris's in-depth study. Also please see James Dawes' Evil Men; Guillermina de Ferrari's Vulnerable States: Bodies of Memory in Contemporary Caribbean Fiction; Catherine Reinhardt's Claims to Memory: Beyond Slavery and Emancipation in the French Caribbean; Johanna R. Quinn's "Haiti's Failed Truth Commission: Lessons in Transitional Justice"; and Hannah Arendt's seminal works including On Violence, Eichmann in Jerusalem, and The Origins of Totalitarianism.

${ }^{2}$ Notable German examples include the genre's earliest known instance, Agathon by Wieland (1765-6), and the bildungsromane of Goethe and Thomas Mann. Other western European examples include Gustave Flaubert's L'Education sentimentale (1869), Daniel Defoe's Moll Flanders (1722), Charles Dickens' David Copperfield (1849-50), Jane Austen's Emma (1816), and Doris Lessing's Children of Violence (1952-69).

${ }^{3}$ Examples of Caribbean bildungsromane by women include Jamaica Kincaid's Annie John and Lucy; Condé's Moi Tituba, sorcière noire de Salem; Michelle Cliff's Abeng; Michèle Lacrosil's Sapotille et le serin d'argile; and Simone Schwartz-Bart's Pluie et vent sur Telumée Miracle.

${ }^{4}$ In this emergent category of the "maroon bildungsroman" I would include key works of Caribbean literature including Danticat's Breath Eyes Memory; Ramabai Espinet's The Swinging Bridge; Paule Marshall's Brown Girl, Brownstones; Pineau's Un Papillon dans la cité and L'Exil selon Julia; Brand's What We All Long For; Philip's Harriet's Daughter; Condé's Hérémakhonon; and Tessa McWatt's Out of My Skin. Interestingly all of these novels are written by Caribbean women writers who live in diaspora.

${ }^{5}$ Bouba Mohammedi Tabti highlights the significance of the titles, particularly the French titles: "The title to E. Danticat's novel, The Dew Breaker, is an evident wink of the eye to Masters of the Dew by Jacques Roumain, a novel whose significance is revealed by the title's bitter reversal of the predecessor's title" (341, my translation). Tabti's original French reads as follows: "Le titre du roman d'E. Danticat, Le Briseur de la rosée, est un clin d'oeil évident à Gouverneurs de la rosée de Jacques Roumain dont la présence s'impose dans un titre qui est le retournement amer de celui de l'ainé" (341).

${ }^{6}$ Scholars have discussed the connection between Papa Doc Duvalier's regime, the largely racist ideology of Noirisme, and an appropriation of Haitian Vodou culture. Less discussed is the connection between the mythology of the maroon and experiences of maroonage. I read Duvalier's invocation of Baron Samedi as a perverted, almost incestuous father figure. Certainly, the association of Haitian Vodou with Papa Doc undermined the reception of vodou around the world.

${ }^{7}$ Tabti: “[le roman] porte la charge des douleurs liées à l'histoire récente de l'île et inscrit la déchirure et la destruction à l'entrée du roman" (343). 


\footnotetext{
${ }^{8}$ Mandelstam was a Russian poet of the Acmeist movement who, along with Anna Akhmatova and others, was deemed by the Stalinist regime to be anti-Soviet because they wrote non-propagandist and dissident poetry, including Mandelstam's "The Stalin Epigram." Mandelstam was forced into Soviet gulags and died in internal exile at a transit camp near Vladivostok.
}

${ }^{9}$ Tabti: [Gouverneurs de la rosée est] "le récit d'un retour [où] l'exil est le lieu de la prise de conscience"; par contre, chez Danticat, "on reste en exil" (348).

${ }^{10}$ Examples of scholarly work on The Dew Breaker includes Marion Christina Rohrleitner's "'Breaking the Silence': Testimonio, Revisionary Historiography, and Survivor's Guilt in Edwidge Danticat's The Farming of Bones and The Dew Breaker" in Interdisciplinary Humanities; Jo Collin's "Between Worlds: Imagining Dyaspora in Danticat's The Dew Breaker and Chancy's The Spirit of Haiti" in ARIEL; and Brinda Mehta's chapter "Dyasporic Trauma, Memory, and Migration in Edwidge Danticat's The Dew Breaker" in 2009's Notions of Identity, Diaspora, and Gender in Caribbean Women's Writing.

${ }^{11}$ Of note, although never mentioned explicitly in the book, is the possibility that Danticat has drawn from the history of the notorious Emmanuel "Toto" Constant, the founder and former leader of the Front for the Advancement and Progress of Haiti (the FRAPH), a militant organization inspired by the lawless tonton macoutes that was responsible for innumerable murders, rapes, and intimidation schemes against proAristide supporters in the 1990s. Toto Constant eventually left Haiti and lived comfortably in Queens for many years before being convicted, not of war crimes, but of mortgage and real-estate fraud. Interestingly, Danticat writes Constant into The Dew Breaker: in "The Book of Miracles," Ka thinks she sees Constant at her family's Brooklyn church on Christmas Eve (78-86). For more on Constant, see the web site "Monitoring the Trial of Emmanuel Toto Constant" by the Center for Constitutional Rights.

${ }^{12}$ Examples of this genre include Goethe's works about Wilhelm Meisters (1777-85, 1795-6, and 1821), Thomas Mann's Doktor Faustus (1947), and James Joyce's A Portrait of the Artist as a Young Man (1916).

${ }^{13}$ Grief and grieving contribute to healing and working through trauma; in societies transitioning from a violent past, grieving processes such as funerals, memorials, rituals, and testimonials can help survivors to move forward. Within diasporic societies, grief can motivate critique from a distance, can inspire a maroon-witness to find his or her voice, and can create the chance to express anger and suffering through creative projects. Committing to preventing the renewed violation of human rights is one thing that can come out of grief; certainly, campaigns such as Holocaust Education Week or Genocide Watch can speak to the "something" that can emerge from grief and mourning.

${ }^{14}$ I have preferred to translate Dominique's text myself, rather than use François' translation of the novel. For each and every text cited in this chapter, the translations are my own work, unless otherwise specified. Please note that the use of italics is purposeful in the original source and that consequently I reproduce it here when applicable.

${ }^{15}$ As an agronomist and later as a long-time radio journalist on Radio Haïti-Inter, Dominique advocated for Haitian self-rule and for the rights of the peasantry to work their own land, speak Haitian Kreyol, engage with their culture, and have a just democratic process. He was outspoken in his critique of Papa Doc Duvalier and Baby Doc Duvalier. Arrested and sentenced to jail for six months, Dominique also spent several years in exile because of threats to his life. His life and career is narrated in the documentary The Agronomist. Ironically, he was assassinated during Aristide's presidency, despite his initial support of that president. His murder remains unsolved and his supporters still chant "Jean Dominique, vivant!"

${ }^{16}$ Edwidge Danticat explores the controversy surrounding Jean Dominique's death in her essay "Bonjour Jean" published in The Nation in 2001. In this essay, Danticat interviews Dominique's widow and journalistic partner Michèle Montas about her campaign to keep his memory alive and bring his killer, or killers, to justice. 
${ }^{17}$ Sourieau: “D'emblée, l'auteure explique les deux courbes géométriques, de son projet d'écriture. En
effet, le texte de Mémoire alterne entre deux formes narratives opposées" (697).

${ }^{18}$ Sourieau: "Le texte de Mémoire d'une amnésique s'enclenche donc sur des techniques d'opposition qui démontrent cette problématique et cherchent à la résoudre à travers le processus du recouvrement de la mémoire" (697).

${ }^{19}$ Sourieau: "Je tacherai de montrer comment l'auteure utilise certaines pratiques d'opposition narratives pour subvertir le 'conditionnement' imposé par l'idéologie dominante masculine, et de ce fait, pour affirmer son identité de femme dans un espace propre reconquis" (696).

20 “'Elle, c'est J. J., l'auteure. Elle a 31 ans et du plus loin qu'elle se souvienne, elle a toujours écrit. Parce qu'elle aime le faire, parce qu'elle en a besoin. Mémoire d'une amnésique est sa première publication. D'autres textes éxistent, ils seront publiés après ... si elle peut!"

21 "L'autre, c'est Paul, narratrice. Elle a 33 ans. Elle écrit. Parce qu'elle aime le faire, parce qu'elle en a besoin. Mémoire d'une amnésique sera sans doute son unique publication."

22 “J'ai essayé dans le titre de rendre cette espèce de contradiction qu'il y a entre le fait de vouloir raconter cette période et de ne pas pouvoir facilement le faire." (Dominique interview with Lucienne Serrano and Yanick Morin in The Women of Hispaniola 128 qtd. in Sourieau 702).

${ }^{23}$ Balutansky offers a neat summary of the naming puzzle in Mémoire d'une amnésique and of its relation to the author's own family: "As Lili explains, she was to have been named Paule (with an $e$ ), but that an illiterate clerk misspelled her name. Like her father, then, she is Paul (without an $e$ ) - though everyone calls her Lili. Her relationship to her father through his name mirrors the author's own position vis-à-vis her father: the author herself is Jan (without an $e$ ) Dominique, though everyone calls her J.J. (which in French is pronounced $<\mathrm{Gigi}>$ and rhymes with $<$ Lili $>$ ). And the author is, in fact, the daughter of Jean (with an $e$ ) Dominique, a well-known Haitian journalist, intellectual, and radio station owner, who was sent into exile on several occasions for his opposition to the Duvaliers" (37).

24 "Paul disait toujours aux petites filles, en regardant des images des quatre coins du monde, qu'il n'y a pas de difference. Pour le choix des amis, la couleur plus ou moins brune, noire ou verte de la peau ne comptait pas, ni le nombre de robes, de costumes neuf, ou de boucles d'oreilles en or. Il refusait seulement les filles et fils de croquemitaine [...]." (94)

25 “Comment ai-je pu si longtemps vivre dans ce pays sans sentir certains rejets?” (94).

26 “pourquoi tes cheveux, pourquoi ta peau, pourquoi tes paroles?” (94).

27 “j'étais la jolie etrangère” (94) mais "Dans les rues de Montréal, je me voyais autre dans chaque vitrine mais sans entendre de réflexions cruelles" (95).

28 “'L'homme en noir était quelqu'un que tout le monde connaissait mais qu'il ne fallait pas nommer, si on en parlait, il fallait faire très attention, toujours en dire du bien, et même pour ceux qui choisissaient de mentir ainsi, ne commettre aucune erreur, personne ne devait s'apercevoir du mensonge. À la petite fille on avait appris à ne rien dire" (35).

29 “'Tu l'as regardé avec un tel mépris. J'ai vu ta mort. Je sais maintenant que tu n'as pas pu saisir le sens des paroles prononcées. Tu n'as pas fait exprès. Tu n'aimes pas André. J'ai vu, en une fraction de seconde, que tu regardais un croquemitaine de cette façon. Il te tuait. Tu devais être protégée. Pardonne-moi quand tu pourras" (38). 
30 "Ils sont là, en plein milieu de la chaussée, devant l'école, plusieurs hommes accroupis derrière une longue voiture noire qui tirent sur d'autres hommes. (Qui sont les bons et les méchants de ce western anachronique?)" (53).

31 “Quelque secondes, ou minutes (en temps réel) ou des heures (par l'angoisse) et c'est le silence, plus terrifiant que les bruits d'avant ..." (53).

32 "les corps allongés au milieu de la chaussée" (53)

33 “A-t-elle entendu le bruit? A-t-elle entendu le silence énorme? A-t-elle vu ce garçon qui l'entendait approcher, s'avancer vers le milieu du silence? Lui a-t il tendu la main pour qu'elle se couche sur le trottoir à ses côtés? A-t-il continué à la serrer contre lui quand on n'entendait plus les balles résonner sur les murs de la grande école? Où sont parties les balles qui ne résonnent plus? La prière sous les bancs de la classe. A-t-elle prié? Dieu ou le Diable?” (55).

34 “Elle n'aurait jamais dû savoir. Elle saura plus tard qu'elle ne pourra jamais oublier. Elle ignorait que la trace des balles serait si profonde dans la mémoire [...] C'était le temps où elle aurait du être heureuse, protégée par l'inconscience" (55).

35 "Elle ne parlera jamais de ce banc d'écolière où elle s'est blottie, tremblante, avec dans les oreilles, sans arrêt, le bruit des balles qui ne ricochaient pas" (55).

36 "Paul, lui, avait bravé la peur, défié la loi, gardé sa fille" (64).

37 "Et malgré tout, elle se souvient" (64).

38 "Vous revoyez ces groupes d'écoliers reconnaissables à leur uniformité vestimentaire. Vous vous souvenez avoir pensé 'mais que font ici tous ces enfants?' Vous avez cru, à ce moment-là, qu'il devait s'y dérouler une cérémonie pour l'inhumation d'une personnalité du pays (écrivain célèbre, éducateur décoré, homme politique?) [...] Quand vous êtes arrivé à cet endroit où tous les autres s'arrêtaient, vous n'avez pas compris ce que faisaient là, au milieu de cet espace vide, deux poteaux dressés sous le soleil" (66).

39 “Cette histoire fait partie de mes cauchemars coutumiers. Je suis à la fois cet étranger halluciné, le guide souriant et la petite fille assise immobile sur son lit tout au long de cette journée. Elle avait eu la possibilité d'être en dehors, il avait été assez fou pour la garder à la maison, malgré la convocation. Cette histoire fait partie de mes cauchemars" (67).

40 “J'ai mal dans ma tête, j'ai faim dans ma tête, j'ai souffert toutes les tortures dans ma tête, car ceux qui ont faim, mal, ceux de la malnutrition, l'analphabétisme, ceux nu-pieds, en haillons, ceux le plus fort taux de mortalité infantile, ceux d'espérance de vie de quarante ans, ceux exécutés sur la place publique ou dans le silence de l'anonymat ... sans l'horreur quotidienne de ceux-là, pourquoi écrire? Et pourtant, distu, partout, tu n'écris pas pour eux" (68).

41 “J'ai commencé à écrire le texte à la troisième personne, pour me cacher, et je sais ce camouflage ridicule, mes doigts racontent 'elle', 'lui', ce que ma tête pense 'je', 'Paul', 'Paul'. Entre les deux, le blocage! Mais il ne suffit pas d'écrire 'je' pour que tombent les multiples bâillons, la couche successive de masques dont j'affuble les personnages [...] Je sens, pour la première fois, le besoin de dire, tout dire, absolument toutes mes histoires racontées dans la tête" (11).

42 “Je ne veux plus rien cacher! Je n'ai plus besoin de me cacher, je ne dois plus avoir peur mais trouver un moyen de ne plus mettre les masques. Toujours les masques" (11).

43، Je réagis comme si j'étais encore conditionnée par des habitudes de silence! Ne pas parler de n'importe quoi à n'importe qui, on ne sait jamais à qui on a affaire. La paranö̈a cultivée par instinct de survie, cette attitude vécue depuis toujours, je la croyais disparue, elle revient sous une autre forme” (11). 
44 "c'est une question de survie, je n'en peux plus de me taire" (11).

45 "L'entreprise est d'autan plus ardue parce que l'auteure / narratrice se trouve doublement sans voix puisqu'elle est victime de l'amnésie générale et femme" (694).

${ }^{46}$ For more on the relation of the bildungsroman to Caribbean literature, see Heather Smyth's 2011 article "'She Had Made a Beginning Too': Beka Lamb and the Caribbean Feminist Bildungsroman" in Genre as well as Joseph Slaughter's discussion of the bildungsroman's relation to the ideologies of colonialism in Human Rights Inc.

47 "Une petite fille s'appelait Paul, mais tout le monde l'appelait Lili. Pourquoi? C'est une longue histoire" (13).

48 "Il faut croire que ça les arrangeait que la petite fille change de prénom. Beaucoup plus tard, quand la petite fille devenue grande a voulu reconquérir sa véritable identité, ils ont tous résisté" (13).

49 “'Je m'aperçois tout à coup qu'un deuxième passé se met à exister, pourtant je n'ai pas encore fait l'inventaire complet du premier, celui de Lili. Depuis douze ans, je suis Paul et j'ignore quel prénom va me coller au corps une fois descendue de cet avion dont les billets, depuis longtemps achetés, attendent sur ma table de travail. Paul existe, Lili m'échappe encore. - pause" (179).

50 "Pourrai-je un jour revenir sur ces phrases?" (188).

51 “J'ignore ce qui m'attend, je ne sais pas ce que je trouverai là-bas, ce qu'il adviendra de moi. Je sais seulement que je trainerai ces pages avec moi le temps qu'il faudra. Pour l'exorcisme. Demain, je pars. pause?" (188). 


\section{Chapter Four}

\section{"Where the stateless might thrive": Queer Diasporic Un-Belonging and the Maroon Memoir in Dionne Brand's $A$ Map to the Door of No Return and Saidiya Hartman's Lose Your Mother ${ }^{l}$}

There is the sense in the mind of not being here or there, of no way out or in. As if the door had set up its own reflection. Caught between the two we live in the Diaspora, in the sea in between [...] Our inheritance in the Diaspora is to live in this inexplicable space. That space is the measure of our ancestors' step through the door toward the ship. One is caught in the few feet in between. The frame of the doorway is the only space of true existence.

Dionne Brand, A Map to the Door of No Return (20)

In the States, nearly every day you are reminded of your losses [...] We didn't mention the hardest things [to the Chief and inhabitants of Salaga, Ghana.] No one said what it has done to us or disclosed the terrible things we do to one another. It would be difficult to explain gangbangers, drive-by shootings, homicide tolls, and missing fathers. Nor did we share the best things, like the way a song born in the cotton and cane fields became something wondrous on the lips of a trumpet player in New Orleans, or something able to cut your heart in two even when the words were as silly as what a little moonlight can do, or a rant about a distant lover, or a chant to bring Babylon down in the mouth of a trench town boy; or the raw-edged beauty that grew between the cracks of everything that was wrong in the urban gulag; or the miracle that we were still here.

Saidiya Hartman, Lose Your Mother (198)

This dissertation's concluding chapter contends most directly with the diasporic experience; here, the mission of the maroon witness is taken up by memoirists who insert themselves into a retroactive literary truth and reconciliation process for slavery, one understood through the quest for home and belonging experienced by the diasporic subject. Significantly, the two memoirs are set in and are concerned with Africa. While the maroon witness in these texts has seemingly arrived "home" to Africa finally, the memoirs ultimately show how home, maroonage, is hard to find for the descendant of slavery and the diasporic subject, who is always inevitably set apart and queer, in the sense of different, unusual, and maligned. 
Since the 1990s, queer theorists have challenged the implicit patriarchal, masculinist, and heteronormative assumptions in studies of genealogies, family trees, and diaspora theory. The 2000 conference Black Queer Studies galvanized the publication of books and articles in response to a need to respond to queer of colour experiences of diaspora. ${ }^{2}$ The conversation relies on concepts of traveling, alienation, unbelonging, and seeking home. Jafari S. Allen writes that black diaspora is "at once about particular locations (actual and imagined); roots / uprooting (principally understood as from Africa, but just as much to and within Africa, in other cases); and routes that bodies, ideas, and texts travel. By diaspora, we refer to these conditions of movement and emplacement, and to processes of (dis) identification, but also to relationality" (216). Pointedly, Allen writes that "black subjects [are] already queer relative to normative ideals of the person" (222) and Rinaldo Walcott argues that "the diaspora by its very nature, its circumstance, is queer [...] the territories and perambulations of diaspora circuits, identifications, and desires are queer in their making and their expressions" ("Outside in Black Studies" 97). Black diaspora studies and diaspora of colour studies therefore work towards creating home spaces for writers and texts who have long been considered the "outside children" of black studies and queer studies (Allen 218-219).

It is from this methodological perspective that I propose a reading of Dionne Brand's A Map to the Door of No Return: Notes to Belonging and Saidiya Hartman's Lose Your Mother: A Journey Along the Atlantic Slave Route. Whereas Brand is an out lesbian whose significant oeuvre regularly features gay and lesbian characters, Hartman's text is queer in its approach, form, and portrait of the diasporic subject. Simultaneously, while Hartman has Caribbean roots on her father's side, she identifies as an African-American 
writer. The pairing of these texts signals my interest in opening up the narrow Caribbean scope of the dissertation to suggest the far reaches of diasporic resonance and to signal a much wider African diaspora landscape. Taken together, the memoirs reveal a relationship between the distance, dissidence, and struggle of the maroon witness and the elusive quest for home of the diasporic queer subject. This final chapter reads the two works as innovative post-slavery memoirs, as particularly maroon memoirs, that contribute, with their "diaspora reading practice," to a queering of diaspora studies (Walcott, "Somewhere Out There").

The attention to queerness in diaspora of colour and black diaspora studies indicates an effort to read diaspora discourse differently. Traditionally queer theory, like liberal feminist theory, did not respond to the dynamic relationship between gender and race. ${ }^{3}$ Gayatri Gopinath calls for a queering of South Asian diasporic discourse in order to contest "dominant diasporic articulations of community and identity [which] intersect with patriarchal nationalist logic" ("Nostalgia" 471). Therefore she proposes a " 'queer diasporic imaginary' [that] undermines hegemonic heteronormative constructions of nation and diaspora, by performatively evoking the spectral figure of the 'impossible subject'; that is, the subject who is necessarily excluded from--but is nevertheless internal to--and whose appearance thus destabilises, these monologic discourses" (75). Interestingly, articulations of queer diaspora allow queer theory itself to become more open to the experiences of people of colour. The burgeoning relationship between queer theory and diaspora theory is thus a vibrant one.

And yet, is a concept like "queer diaspora" possible since there is no queer homeland, no queer place of origin to miss, aspire to, or invoke? Johanna X. K. Garvey 
suggests that queer (un)belonging refers not to nostalgia for a specific queer homeland but rather to a concept that revisions the world and upholds new possibilities of community and intersectionality, because the phenomenon of home itself is a vexed concept for queer and diasporic subjects. Garvey's argument follows from Kim Butler and Rogers Brubaker who suggest that diaspora in general can be best discussed in relation to community-formation and practices, rather than exclusively in relation to ethnicity or homeland. Garvey works with invocations of Toronto in Brand's 2002 long poem Thirsty and her 2005 novel What We All Long For to demonstrate how "Brand's work asserts the positive potential of spaces of queer (un)belonging, that is, spaces that undo belonging while not leading to the destructive erasure of not-belonging" (758). Garvey writes in a footnote that "Brand's position as a queer diasporic writer has not been extensively studied to date" (773), and Hartman's work has not been read according to this modality either. This chapter addresses how the articulation of queer diaspora and queering of identity interacts productively with Hartman's and Brand's articulations of belonging and unbelonging. In particular, I argue that the figure of the diasporic maroon witness is emboldened by a sense of diasporic queering of space, identity, and narrative.

What is the cost of yoking together the disparate threads of queer diaspora, postslavery memoir, and maroon witness poetics? While it is possible to flatten out distinctions with such a method, I see the potential of a productive conversation across difference when "putting forward a connective rather than comparative approach" (Hirsch and Miller 8). A connective approach can be "a corrective to the nationalist and identity-based tendencies at work" (3) in memorial projects, fundamentalist religion, extreme nationalism, and what Edward Said called the "triumphant ideology" 
(Reflections on Exile) that generated and continues to engender much oppression and violence. My attention to productive connections between seemingly divergent experiences, genres, and histories is a methodology informed by Édouard Glissant's "multirelation" and Michael Rothberg's notion of multidirectional memory. Brand's and Hartman's memoirs attempt to respond ethically, but differently, to the legacy of the slave trade, one from the perspective of a subject who identifies herself as TrinbagonianCanadian, and one who is African-American, with roots in the American south as well as in Curaçao: both are diasporic subjects, and their memoirs confront belonging and unbelonging across and beyond the Black Atlantic. Together these memoirs reveal queer diaspora as a robust site of productive intersectionality.

\section{The Slave Narrative, Diasporic Life Writing, and Memoirs of Return}

Works in the slave narrative genre, although often narrating an individual experience of resilience, also reveal and stand in for the experience of a collective. In contrast, the traditional autobiography, testimonial, and memoir often begin from the position of a first-person survivor and narrate a personal experience. Yet when approached from a human rights-oriented perspective, autobiographies often represent and advocate for the righting of an injustice, and testimonials and narratives are increasingly used to pursue human rights claims in courtrooms, communities, and culture. ${ }^{4}$ Autobiographical accounts of slavery, as well as historical fiction written by contemporary writers but set in the slavery era, offer a critical historical perspective as well as a major literary influence on North American, postcolonial, Caribbean, and African Diaspora literatures. This tradition is considered, along with the testimonio, to be 
the precursor to the genre of postcolonial life-writing, whose notable examples include the slave narrative of Olaudah Equiano (The Interesting Narrative and Other Writings, 1789) and the testimonio by Rigoberta Menchú (I, Rigoberta Menchú: An Indian Woman in Guatemala, 1983).

A relevant critical situation, in the increasingly vibrant field of human rights discourse and human rights literature, is the turn away from a specifically legal and political focus towards the productive possibilities engendered by the artistic, cultural, and literary spheres. This turn indicates a movement away from an over-emphasis on Western, psycho-analytic understanding of trauma to one that is open to multi-cultural and indigenous understandings of suffering and healing, storytelling and life writing. Accordingly, scholars recognize the role of personal narratives and memoirs in human rights campaigns. In Narrated Lives Kay Schaeffer and Sidonie Smith study the boom in memoir writing and personal life narratives, including examples such as Menchú's, and its significance to the field of human rights legislation and discourse. Tracing a trajectory from the European war memoir that led to the drafting of the Geneva Convention to $I$, Rigoberta Menchú's influence on Mayan sovereignty struggles, the authors delineate the strong link between published personal narratives and the mobilization of attention and action on human rights violations.

Sophia McLennen and Joseph Slaughter discuss how the literary "vehicles" in which human rights "travel" have to be examined (4). Careful to underline that human rights scholars cannot over-value cultural endeavors as "the answer" to human rights violations, they nevertheless suggest that culture must play a critical role, along with legal and political systems, in protecting human rights and advocating for action when 
and where violations occur. While McLennen and Slaughter suggest an opening up of the category of human rights literature nevertheless their work has been concerned exclusively with the novel genre. By contrast, my interest here is in the memoir genre, a genre that "has become an increasingly productive form for exploring the meaning of family, generational identity, and ethnicity, as well as one for researching a past marked by historical calamity--the losses caused by the vicissitudes of violence, war, and genocide" (Hirsch and Miller 10). This chapter considers the genre-blurring and innovative category of diasporic life-writing, and of a particular sub-category I identify as the queer diasporic maroon memoir. My interests are formal, theoretical, and thematic, and I demonstrate how this sub-category distinguishes itself from other examples of Caribbean women's life writing and from postcolonial memoirs in general. This chapter draws links between the innovative form of Brand's and Hartman's texts and their interest in loss; ultimately I suggest that the memoirs reveal a distinct sense of separateness, distance, and isolation, as well as a quest for community, that recalls the historic experience of maroonage as well as the queer experience of unbelonging; in both cases, the pursuit is for the refuge of home.

\section{Impossibilities of Longing and Belonging in A Map to the Door of No Return}

Throughout her oeuvre, Brand is deeply concerned with the cultural, traumatic, and historical legacies of the diaspora experience. From her early novel of migration In Another Place, Not Here, to the radical poetics and struggles to find community in Thirsty, No Language is Neutral, and Land to Light On, to the international concerns of Ossuaries, At the Full and Change of the Moon, and What We All Long For, Brand 
explores the experiences of contemporary diaspora and its relation to the Middle Passage, colonialism, and the maroon experience of being in-between. Land to Light On heralds the questions of citizenship, belonging, and alienation that Brand explores in her later works Inventory, What We All Long For, Ossuaries and, of course, A Map to the Door of No Return. In Land to Light On, the speaker cannot find a footing in her rural Canadian present: "I have been losing roads," she laments (Land 15). The landscape of northern Ontario is cold, hostile, and the people, racist and unwelcoming; in addition, she feels stifled and disillusioned when writing poems about stacking cords of wood rather than about revolutions and struggles. The speaker is nostalgic for the life in Trinidad she left behind in exchange for the isolation and time to write she has in this cold landscape, and she simultaneously laments the hectic activist work she used to do in Toronto. Moreover, she is haunted by her experiences in Grenada, where she joined the revolutionary struggle and was nearly killed. That island with a weapon in its name, and the revolutionary struggle work it symbolizes, continues to haunt her. ${ }^{5}$ Framed by the rupture of the Middle Passage and the irrevocable separation from an ancestral past caused by the Door of No Return, the diasporic subject finds home uneasily. As Land to Light On asks, with what can the speaker replace a "country" if she gives up on it? Where else will she find maroonage?

In the conclusion to Land to Light On, the speaker admits that she has decided to "give up" on maps, borders, and countries, and that indeed she has never believed in them. Since the Middle Passage ripped slaves and their descendants out of history and out of their pasts, European conceptions of time, place, and cartography cannot be enough. Political borders for Brand's speaker are inadequate and cannot in fact honour her true 
experience. Brand's speaker could continue to drive north, might continue to recall her Trinbagonian past, might regret her break from political activism, but each of these experiences will only be placeholders for the home she cannot find. If anything, Brand's speaker in Land to Light On chooses instead to believe in the possibility of Salman Rushdie's homelands of the imagination ("Imaginary Homelands"). Perhaps the diasporic subject can only be at home in a metaphoric and figurative place where loss and hope can interact in simultaneous tension (Clifford 312), where disappeared countries can be evoked but never recovered.

The distress of "losing roads" equally troubles the speaker in A Map to the Door of No Return. Brand's memoir begins with the speaker's lament that she does not know her family's origins. She recalls that her grandfather claims he once knew, and then he forgot, but in fact it is questionable whether he ever knew the truth at all about where they came from: "Yoruba? Ibo? Ashanti? Mandingo?" (Map 3). Her grandfather never remembered. With this disappointment, the poet at 13 comprehends the experience of diaspora: "We were not from the place where we lived and we could not remember where we were from or who we were. My grandfather could not summon up a vision of landscape or a people that would add up to a name. And it was profoundly disturbing" (5). As Brand explains, this complete void of knowledge about where in Africa her family originated from is a common experience for diasporic subjects: "That moment between my grandfather and I several decades ago revealed a tear in the world [...] the rupture this exchange with my grandfather revealed was greater than the need for familial bonds. It was a rupture in history, a rupture in the quality of being. It was also a physical rupture, a rupture of geography" (4-5). Subtitled "Notes to Belonging," A Map to the 
Door of No Return narrates a quest for origins that are impossible to find and seeks a deeper understanding of the experience of unbelonging that marks the legacy of the postslavery diaspora.

Brand writes that diasporic subjects "have no such immediate sense of belonging, only drift" (118), whereas their ancestors "were bewildered [by their capture] because they had a sense of origins--some country, some village, some family where they belonged and from which they were rent" (118). The slave trade and the experience of captivity essentially took apart generations of kinship ties and elaborate social connections, so that slaves, who had been native to somewhere, became strangers elsewhere. Consequently, Brand's speaker seeks connection with Indigenous people and with the possibilities of aboriginal heritage in her own family, no matter how distant. Brand describes a drive through the countryside on the island of Dominica, in what she refers to as Carib territory. When she stops at a road-side shop, she is embraced like family by an Indigenous man and his children who, although strangers to her, recognize some kinship in her body and presence. The speaker wants to belong somewhere, to be from some place, and though the link is blurry and ancient she feels a pull to stay with this family:

A Carib man looks me in the eye as if he knows me and I settle into his look [...] We climb back into the van and he looks at me again as if I should be staying and where am I off to now, and I am half surprised but half convinced that, well, of course I should be staying. He sent his son, like my brother, to give me a small basket as a gift, as if to say, 'Well, here then, go if you're determined, but take this with you.' I had noticed at the back of the shop, my sister, his daughter, a whole 
world was in her face, 3000 years of Ciboney, then Arawak, then Carib canoeing north from South America, before it was South America, 1000 AD. In her face all the battles against the French and English for two centuries [...] until settling to the west and east they crept into her face, too. In her face, now African, which people? Ga? Ashanti? Ibo? Washed in, wept in, with all the waters of the hundreds of rivers and rivulets [...] And all this Dahomey in her face that would name the valley to the southwest the Valley of Desolation. (137-138)

Bereft of the certain knowledge of her African origins, the speaker wants to identify with people she knows have an ancient relation to the Caribbean region, despite the conquests and the miscegenation. The Carib family she meets is from where they live, despite and because of "a whole world" etched in the face of the daughter, and the speaker tries to imbibe some of their belonging by swimming in all the rivers of Dominica, as well as by, hopefully, calling the family members her brother, her sister. This scene recalls the moment in Inventory when the speaker is greeted as cousin by an Egyptian man. In both instances, the speaker's eagerness to find connection signals the loneliness of the diasporic maroon subject and her need for kinship.

The speaker's interaction with the Carib man raises a vexing question: can a diasporic subject ever be indigenous to a place? If, by nature, a diasporic subject is from elsewhere, can he or she ever become indigenous, ever truly belong to a place in the same way an aboriginal person can belong to their ancestral territory? Can the diasporic person ever be fully embraced by the land, air, animals, and people of the place she has landed upon, or is the diasporan forever a nomad and stranger? James Clifford writes that "precisely how long it takes to become indigenous is always a political question" (310) 
and a contentious one at that. Although he underscores that "tribal cultures are not diasporas [because] their sense of rootedness in the land is precisely what diasporic peoples have lost" (310), nevertheless "tribal-diasporic opposition is not absolute" (310). Since many tribal peoples have been disenfranchised and dispossessed of their lands, many now live nomadic, diasporic lives as they travel between urban and rural centers, and their struggle for enfranchisement may also involve "a diasporic dimension" (310) that imagines a return to an original homeland and way of living. Clifford is right to note that indigenous groups have always travelled and been "rooted and routed" in landscapes and networks, and that what is in fact relatively new or "modern" is the "relentless assault on indigenous sovereignty" by political and economic powers (310). A contentious issue in postcolonial studies is whether or not, ultimately, diaspora and indigeneity are antithetical terms.

Towards the conclusion to A Map to the Door of No Return the speaker reveals that "it was said in my family that my grandfather was part Carib" (222) and that the "parts" of him that were Carib included his cheekbones, the "tawny hue" of his skin, and "the occasional straightness of regions of hair on his head. The rest of my grandfather [...] the majority of him, was African" (222). The speaker is adamant that there was no war, there never had been, both had settled calmly in my grandfather. They shared a common history. The Carib part grateful for its small survival in my grandfather's face [...] The African part of my grandfather carried him as a courtesy and a welcome obligation and perhaps also in gratitude himself for sharing with him the knowledge of the islands. (222) 
Here Brand's articulation of her grandfather's history, embodied in his face, hair, and skin, represents thousands of years of conquest, miscegenation, and shared knowledge. This same grandfather, who cannot remember where in Africa the family comes from, nevertheless also holds other knowledge in the very panes of his face. And yet, as with the Carib girl who the poet meets in the mountains of Dominica, the "whole world" in his face calls up "Desolation" (138).

The speaker in A Map to the Door of No Return is "routed" if not "rooted," constantly moving and travelling. The scenes in the book narrate plane journeys, arrivals via cars or long hikes, and travels to England, St. Lucia, Grenada, Dominica, South Africa, and Germany, among other countries. Brand writes that even when she describes the northern Ontario town she lived in for three years, she can only use the expression "landing": "Landing is what people in the Diaspora do. Landing at ports, dockings, bridgings, stocks, borders, outposts. Burnt River is another outpost [...] I had no destination in mind. I am without destination; that is one of the inherited traits of the Diaspora. I am simply where I am; the next thought leads me to the next place" (150). Always unmoored, the diasporic subject has no solid ground to tether herself to. Significantly, queer diaspora takes up the phenomenon of rootlessness as a defining trope.

Ironically, this rootlessness suggests that the African and Caribbean-diasporic subject has no homeland at all, cannot quite belong anywhere. What does this assertion do to the general definition of a diasporic subject as one who is separated from his or her homeland? If "homeland" is uncertain for the Caribbean subject, especially if he or she is mixed-race, then the homelands and cultures of origins are multiple and far reaching: 
Amerindian; African of multiple yet unknown cultures and ancestries; East Indian; Chinese; Jewish; Middle Eastern ... As Brand describes, even a non-mixed Caribbean person has no idea where exactly her people came from: "the descendants of the nineteenth-century Indian and African Diaspora [...] have no ancestry except the black water and the Door of No Return. They signify space and not land" (61). The assumption of indigenous belonging to a nation and homeland might, for Caribbeans, be simply an impossible dream.

Brand writes that "our inheritance in the Diaspora is to live in this inexplicable space" (20). From this space of unbelonging, the only definite fact is the fact of rupture itself as represented by the Door of No Return, the metaphorical name for all the "doors" leading between the slave castles and the cargo holds of the slaving ships. All descendants of African slavery can, ironically, know nothing else about their family histories other than that at least one ancestor passed through such a door in his or her transformation from human being to slave. The door is an absent presence that overdetermines the lives of diasporic subjects: "though few of us have seen it, or consciously attach importance to it, this door in its historical connectedness was the point of departure, not only physical departure but psychic renting, of our ancestors" (21). Brand writes that "some of us in the Diaspora long so for nation--some continuous thread of biological or communal association, some bloodline or legacy which will cement our rights in the place we live. The problem of course is that even if those existed--and they certainly do $[\ldots]$ they do not guarantee nation for Blacks in the Diaspora" (67). As Hartman articulates in Lose Your Mother, even discovering the African nation of origin, itself a Herculean task, does not lead to automatic identification or to feelings of kinship 
for the descendants of slavery. During the slave trade, slaves were pulled from their communities and removed from their families, and so even before they passed through the Door, their very status as captives reconfigured them irrevocably as foreigners and strangers who had "lost their mothers" and therefore no longer belonged anywhere. Thus with this renting began the experience of diaspora in the New World.

In an interview in Quill and Quire from 2010, Brand gives testimony to the psychic and physical unbelonging experienced by the descendants of slavery and the diaspora: "I am directed by rootlessness," she says. "I want to draw new maps" ("She's a wanderer"). In A Map to the Door of No Return Brand writes that when she was growing up in Guayaguayare, Trinidad, one of her uncles was a schoolteacher who, as a compulsive hobby, made African masks out of metal: "[he] beat [copper] masks out of himself every afternoon after he came home from school" (21). Although he was "not a scholar of African art of any kind" nor did he have actual memories or "recall of the Baule, the Oan, the Mossi, the Ogoni, the Sennefo, the Ngbaka, or the Akwaya," he somehow created masks out of nothing: "My uncle only had the gaping Door of No Return, a memory resembling a memory of a thing that he remembered. And not so much remembered as felt. And not so much felt as a memory which held him" (121). The speaker's uncle reaches for the recognition of home and homeland through the physical struggle of mapping his memory and history out of copper.

Brand likewise draws new cartographies by experimenting with the formal aspects of A Map to the Door of No Return. The book's back matter refers to it as "Autobiography" and as "an insightful book of discovery" (Map). From the five pullquotes on the back jacket, The Ottawa X Press writes that "Dionne Brand pushes the 
boundaries of narrative non-fiction to create an erudite and deeply personal meditation [...] [A] haunting and haunted confessional" and The Ottawa Citizen assures the reader that they can "open it anywhere and start reading and it makes sense $[. .$.$] her true home is$ not Africa, the Caribbean or Canada, but poetry." The book's para-textual evidence is complimentary but essentially ambivalent: to which genre does this book belong? Is it autobiography, poetry, a meditation or a confession? Narrative auto-fiction? Yet the book's title describes itself as a map, rendered as "auto-bio-cartography" in Garvey's words (758). The book is structured like a collection of brief essays, scenes, or prose poems all related to a common theme, with italicized titles such as "Arriving at Desire" "Finding a Compass" "Voyage," and "Museum." If the scenes are long they are divided into multiple parts marked 1, 2, 3, etc. Each scene is aptly named according to a metaphorical concern with navigation, and each is separated by even shorter reflections that are all given the same repeated title: "Maps." The book overflows with references to doorways, modes of transportation, roads, being lost, traveling, and seeking. This book is a contradiction in terms; it is a map to a door that does not exist except in the imagination, and it promises "Notes" to a "Belonging" that is ultimately impossible.

Within the text, Brand refers to several other genres of literature: a ruttier--a navigational poem for sailors; a rihla, which is "a traveller's account of a pilgrimage" (Map 86); films and documentaries; books of history including The Black Napoleon in which the poet "met a history [she] was never taught" (186); writings by William Bosman and Mungo Park; and newspaper articles. Her many references to writers and literature include André Gide whose words accompany her in "Voyage," the scene that narrates her first trip to the African continent; Aimé Césaire's poetry, read before dawn: 
"In the room at 4:50 a.m., reading this, I decide to be a poet. Césaire is still writing" (58); a letter of Pablo Neruda's which gives her "comradeship" (99); J. M. Coetzee's Disgrace which she reads alongside Toni Morrison's Paradise on a wide-eyed plane-ride to Australia; Jean Rhys' Wide Sargasso Sea which she remembers when visiting the actual town of Massacre, Dominica: “And who was massacred here? Slaves?" "Oh no,” Antoinette answers, foreshadowing her own erasure in Charlotte Brontë's Jane Eyre, "Not slaves. Something must have happened a long time ago. Nobody remembers now" (Rhys qtd. in Map 138). Brand's narrative from the diaspora is far-reaching, loose, untethered, and uninterested in categories. The memoir is a vast and insatiable exploration of loss, memory, identity, and history, and it "offers a venue for rethinking the ways to remember and memorialize Caribbean transatlantic experience and history" (Mehta 12). The book moves with urgency and "refuses to let the violence of the past be buried" while somehow, simultaneously, "[dreaming] of possibility" (12).

Importantly, Brinda Mehta explores the importance of the formal experimentation undertaken by diasporic writers and the relation of this innovation to the abovementioned themes of violence, trauma, resistance, and identity: "the originality of these writers lies in their strategies of narrativizing the Caribbean through a gendered transnational lens $[\ldots]$ they are subject to the transformations and accommodations that become a part of the diasporic process and its repeated transmutations" (10). Formal experimentation is a productive avenue for postcolonial women writers who "tend to mix genres in a manner we have not seen in mainstream autobiographies'“‘ (Torres 15). Innovation of form, thus a queering of form, leads to productive possibilities in the 
diasporic autobiography; Brand's integration of multiple genres as well as multiple authorial voices and references indicate an interest in openness and inclusivity.

Brand's speaker, her many queer female characters, and indeed the poet herself, engages in a critical re-conceptualization of belonging based on a history of loss and longing. Here, forgetting allowed for survival: forgetting "was passed on [...] was a gift. Forgetting. The only gift that one, the one bending reluctantly toward the opening, could give" (Map 224). A variation of the traditional maroon figure who seeks the liberty of free communities, the queer female subject, and especially the queer female artist, experiences longing and seeks belonging, yet finds nothing that is not already infected by loss. Consequently, queerness involves "an insistence on potentiality or concrete possibility for another world" (Muñoz qtd. in Allen 222). ${ }^{6}$ Despite her openness to difference and to different voices, the speaker cannot find home, and can only continue to move and travel. Belonging, for a diasporic subject and heir to the Door of No Return, is thus inevitably complex, a queer flight born out of forgetting, memorializing, and rupture.

\section{Becoming Obruni: Forgetting and Remembering in Lose Your Mother}

As I disembarked from the bus in Elmina, I heard it. It was sharp and clear, as it rang in the air, and clattered in my ear making me recoil. Obruni. A stranger. A foreigner from across the sea. Three children gathered at the bus station shouted it, giggling as it erupted from their mouths, tickled to have spotted some extraterrestrial fallen to earth in Ghana [...] Obruni forced me to acknowledge that I didn't belong anyplace. The domain of the stranger is always an elusive elsewhere. I was born in another country, where I also felt like an alien and which in part determined why I had come to Ghana. I had grown weary of being stateless. Secretly I wanted to belong somewhere or, at least, I wanted a convenient explanation of why I felt like a stranger.

Hartman, Lose Your Mother (3-4)

Hartman's Lose Your Mother: A Journey Along the Atlantic Slave Route appears at first to be a classic memoir of return, the personal quest-narrative of an African- 
American woman who travels to Africa in order to return to her homeland and find her roots. However, Hartman demonstrates that a meaningful return to Africa is impossible for the diasporic descendants of slavery. Despite a political and economic interest in developing "atrocity tourism" and "homeland tours," Hartman writes that the social culture and traditions of West Africa encourage a culture of forgetting rather than a culture of remembering around the history of slavery. Consequently, diasporic subjects can never find their "homeland" in Africa and thus, it follows, might never belong anywhere. Like the queer subject who is always considered different than the norm, the diasporan is always queer, and lives in the world queerly, not quite ever fitting in. Hartman's loneliness and alienation is seductive, especially to a diasporic reader. The book's central image of the slave as a stranger who has lost her mother, defined by the term obruni, and the way that term bubbles out of the mocking mouths of giggling Ghanaian children, propels and defines Hartman's quest to find belonging. Although she is never able to un-lose her mother, or find her "roots," the book nevertheless closes with the revelation of the elusive "freedom trail" Hartman had been dared to find instead of the obvious slave route; if she finds belonging, it is in the freedom trail and the experience of fugitives from slavery: African maroons. Through its poetry, mixed genres, historical material, and archival offerings, the book manages to convey a deeply complex history and an urgent desire to understand how to live in, and in spite of, the diaspora.

Lose Your Mother is an unusual memoir in that its material could have easily been packaged as an academic study. The book is a readable and poetic meditation on the author's experiences living in Ghana for a year on a Fulbright Scholarship from 19971998 , in addition to articulating what she gleaned from her research into the West- 
African slave trade. Hartman states her dual motivation: "As both a professor conducting research on slavery and a descendant of the enslaved, I was desperate to reclaim the dead, that is, to reckon with the lives undone and obliterated in the making of human commodities" (6). Reflective of her scholarly and personal projects, the poetic prose is un-encumbered by citations and footnotes, and the chapters read like a novel might, while the archival and historical information never overwhelms. The book relegates all the notes, references, and explanations to a twenty-one page series of endnotes organized by page and chapter. Reading the text itself is a seamless experience because the existence of the associated notes is not indicated on the page itself, and thus can be totally ignored in favour of the momentum of the narrative. For example, although the book's first note is associated with page 5 , there is no marker on page 5 to indicate this; a casual reader could therefore entirely ignore the origin of the term "white slaves" that the author uses on this page but which she explains on page 237 of the endnotes. Similarly, the illustrations and photographs that pepper the text, as well as the concluding index, support the text in a discreet way but do not overtake it. The result is a deeply informative novelistic account of both the African slave trade and the experience of diaspora, but one that is also a meticulous research report from a postdoctoral fellow's investigation of the slavery archives.

Women life-writers tend to "experiment at the boundaries between different writing forms" (Stanley 13). Even more assertively, "the progressive woman autobiographer 'refuses to obey the prohibitions of the father's culture' " (Smith, Poetics 59). Significantly, Hartman does not shy away from sharing her vulnerability, loneliness, and “dark zone of private grief" (Hartman 214). The book is organized with careful attention 
to the sensory and emotional experiences of the author and, also, that of the reader. "Prologue: The Path of Strangers" opens the book and sets out the parameters, the memoirist's personal quest, and the challenges she will face in Ghana: "Unlike Alex Haley [...] [who] was feted as the lost son returned, I traveled to Ghana in search of the expendable and the defeated" (7). The twelve chapters, with their poetic titles such as "Markets and Martyrs," "Come, Go Back, Child," "The Dark Days," and "Blood Cowries," highlight the complex themes of the book and the relation between emotional issues, sensory experience, local mythology, and historical fact. The author does not shy away from expressing her personal frustrations as an ex-pat African-American in Ghana, her uncertainties as a diasporic subject, or her struggles as a researcher. The narration of the emotional and cultural experiences reveal a parallel slavery archive that leads, ultimately, to the discovery of the fugitives' trail that will nurture the writer. Overall the book's exploration of the emotional and the academic provides a wide, oceanic scope.

Lose Your Mother emblematizes the experience of an individual's thwarted return to an irretrievable home that was lost hundreds of years ago. Hartman's consideration of the West African term for stranger, obruni, opens the book and propels its narrative, as the writer tries to understand how the shameful social concept of stranger and becoming a stranger both permitted and legitimized the slave trade, while at the same time engendering and entrenching the racialized and alienating legacy of diaspora. In her challenge to the popular Roots-like quest for African-Americans to find their African culture and village of origin, "Hartman is impelled not by a desire to recover a lost homeland but to witness, record, and repair a history of injury through which lives are undone and humans are transformed into commodities" (Hirsch and Miller 2). And yet 
despite her consideration of historical material, archival research, and social commentary, "Hartman searches for her own beginnings, for how the spaces and traces of enslavement 'had created and marked [her]' “ (2). She realizes that her perpetual feeling of alienation and queerness is irrevocably yoked to her heritage as a descendant of slaves.

Always an outsider in the US, she is shocked by how she is othered in Ghana. Evidently American, evidently African-American, the Ghanaians recognize her as a "slave baby" (Hartman 4), a descendant of slaves, one who is to be pitied because she has been removed from her original family and therefore has no community, no kin, no village, and is therefore a "stranger." Indeed in West Africa, "slave" means "stranger":

The most universal definition of the slave is a stranger. Torn from kin and community, exiled from one's country, dishonored and violated, the slave defines the position of the outsider [...] I had come to Ghana in search of strangers [...] Ghana was as likely a place as any to begin my journey, because I wasn't seeking the ancestral village but the barracoon. (5)

One of the ways in which Hartman undercuts the myth of return is through her scathing portrait of the reception she and other Americans receive from Ghanaians and West Africans. According to the author, even her African academic colleagues "gave [not] much thought to the way their history was enmeshed with mine, nor did they entertain the idea that the Africa in my hyphenated African-American identity had anything to do with their Africa. They made it clear: Africa ended at the borders of the continent" (225). For her colleagues, and indeed in general for the Africans she meets, "Diaspora was really just a euphemism for stranger" (215), another indication that the social stigma about slavery was inherited forever, from generation to generation. ${ }^{7}$ 
While Hartman and other descendants of slavery continue to grieve the slave trade, the author's African colleagues are detached, indifferent, and pragmatic. ${ }^{8}$ Since the 1990s, West Africans had been encouraged to ignore centuries of social decrees and legal prohibitions about acknowledging slavery in order to, finally, remember slavery as part of a tourism initiative to lure and appease the thousands of American tourists who eagerly "return" to their African homelands: "Every town or village had an atrocity to promote--a mass grave, an auction block, a slave river, a massacre” (163). Hartman reveals that "Door of No Return rituals, reenactments of captivity, certificates of pilgrimage, and African naming ceremonies framed slavery primarily as an American issue and as one of Africa's relation to her 'lost children' “ (163). While tourism boards and local villages throughout West Africa promote holidays and tourist packages that promise a "return" to African homelands and a discovery of "roots," this propaganda is in opposition to a centuries-old practice of perpetuating the culture of forgetting slavery. ${ }^{9}$

Hartman describes how "in every slave society, slave owners attempted to eradicate the slave's memory, that is, to erase all the evidence of an existence before slavery. This was as true in Africa as in the Americas. A slave without a past had no life to avenge" (155). Thus in order to protect themselves from future revenge and mutiny, the slave trading societies enacted social dictates and laws "which prohibited the discussion of a person's origins" (154), essentially making it illegal to proclaim someone's slave heritage which would publicly shame them. Masters, merchants, chiefs and kings cooperated with fetish priests and religious leaders to develop elaborate rituals and potions used to eradicate memory and instill forgetting. The use of amulets, shrines, tonics, "herbs, baths, talismans, and incantations transformed slaves into blank and 
passive automatons" (155), and slaves would be forced to walk around a particular tree, through a "forgetting" grove, or be bathed in a river or stream "whose water made slaves forget their pasts" (156). Hartman discusses a medicine derived from a leguminous shrub found in the savanna that "transformed able-bodied men and women into vacuous and tractable slaves" (157); known as Crotalaria arenaria, its name in the Hausa language literally meant "manta uwa" or "forget mother," lose mother (157).

All of these different forgetting potions and rituals were thought to ensure that the slave would become a kind of zombie, wracked with amnesia, who could no longer remember where he came from or who he was: "Everyone told me a different story about how the slaves began to forget their past. Words like 'zombie,' 'sorcerer,' 'witch,' 'succubus,' and 'vampire' were whispered to explain it [...] the particulars varied, but all of them ended the same--the slave loses mother" (155). Hartman states that forgetting was always a punishing consequence of capture: "never did the captive choose to forget; she was always tricked or bewitched or coerced into forgetting. Amnesia, like an accident or a stroke of bad fortune, was never an act of volition" (155). As I elaborated in Chapter Two, Caribbean vodou developed by the descendants of these same slaves absorbed this fear of zombification and created a whole practice to protect people from this fate, this reenslavement. ${ }^{10}$ For traditional West African societies at the time of the slave trade, forgetting your past and your village, essentially "losing mother," meant that a captive could no longer remember which local gods to worship, which ancestors to pay their respects to, and which shrines to pray to. Without a deep connection to the religious rites or to her lineage, the slave no longer had a role to play in the machinery of her village's society, and she was considered irrelevant and unprotected until she was absorbed into a 
master's household. A veritable orphan, the slave became a stranger to her community as well as a stranger in a new land or village: she became, essentially, a diasporic subject. Hartman discovers that in the writings by European slave traders of the fifteenth century, the region between the hinterland and the coast "swarmed with amnesiacs, soulless men, and walking corpses" who "soon forgot all about their own country" (Joan Dayan and Zurara qtd. in Hartman 157). The terms "negro" and "donkor" were used to describe these nation-less, soulless captives who no longer belonged to an ethnic group or nation. As Césaire writes in the Cahier, and as Hartman translates in Lose Your Mother, "like the term 'nigger,' donkor implied that 'the human pulse stops at the gate of the baracoon'“ (158). The experience of captivity and slavery thus induced the forgetting, orphaning, loss of home, and loss of mother that continues to be the inheritance of the diaspora. While Africans continue to want to "forget" and diminish the slavery past because they traditionally find it shameful, the mission to remember is vital to AfricanAmericans: "In the United States, black people's insistence on reckoning with slavery in the face of national indifference, if not downright hostility, has been an effort to illuminate the crushing effects of racism in our lives" (165). This discursive difference reveals a deep discord between Africans and African-Americans, a discord that inherently widens the diasporic gap between the continents and the heirs to the histories.

When the author and a few of her friends visit the legendary slaving capital of the Salaga Empire, the group has a conference with the Chief, as is customary. While they try to comprehend why his community refuses to discuss the slavery past or admit to the repressed slave heritage of some of its inhabitants, Chief Suleiman tries to understand why Hartman and her African-American friends are so desperate to learn about it. "What 
is it you want from Ghana?" the Chief demands. Hartman writes of her uncertainty:

Had we possessed the words, we might have said that it was not as if we expected to find something that could make history hurt less or fill the hole inside of us, because it was not the kind of hole that could be filled and then would go away.

Coming here was simply a way to acknowledge it. There was no turning back the clock. But it didn't feel like it was moving forward, either. (199)

Hartman's answer, belatedly, is Lose Your Mother, with its lament for the experience of loneliness, impossible returns, and diasporic difference. Like Césaire's Cahier, the book narrates the author's prise de conscience and manifesto for her people, because it refuses to engage in the process of forgetting that for so long silenced the histories and lives of the slaves in Africa and the New World. By inserting herself into the slavery archive as a maroon witness, Hartman galvanizes a testimonial process for the slave trade. The author may not find her lost mother, but she importantly refuses for herself, or any other descendant, to continue to "forget mother."

\section{Confronting the Door of No Return in A Map to the Door of No Return and Lose Your Mother}

In Rites of Return, Hirsch and Miller discuss "museums and memorials that facilitate the process of site-specific remembrance" (15) and the current preoccupations in scholarship as well as tourist interest that sustains the industry of memory. For its part, the International Coalition of Sites of Conscience declares that "it is the obligation of historic sites to assist the public in drawing connections between the history of our sites and their contemporary implications" and thus their mission includes "stimulating dialogue on pressing social issues and promoting humanitarian and democratic values as 
a primary function" (15). The Coalition oversees seven accredited sites and over a hundred affiliated sites including the District 6 Museum in Cape Town, the Maison des Esclaves in Senegal, and the Terezín Memorial in the Czech Republic (15), and is part of a movement to "promote responsible memory tourism on the sites of former acts of atrocity or suffering" (16). While a fixation on physical sites might lead to an obsessive over-fetishization of place such as the "tropolatry" that Andreas Huyssen warns against in his work (16), and even though "places do not actually themselves carry memory," nevertheless "memory can be activated by the encounter between the visitor and the place" (17). In both A Map to the Door of No Return and Lose Your Mother, the authors are compelled by what seems like a typical diasporic quest, that is, to go not only to Africa, but also to go to a slave castle or dungeon and be in the physical space symbolized by the expression "Door of No Return." Despite these great expectations of connection and comprehension, each author reveals her disappointment and the eventual, grim understanding that a connection to a past diasporic homeland can only be elusive and intangible. The witnessing from a distance that is so characteristic of the maroon figure is not necessarily satisfying; while in Inventory the maroon witness watches the events in Iraq mediated by the television screen and the news agencies, in the two memoirs, the maroon witness is separated from the scene of the crime by hundreds of years.

In A Map to the Door of No Return, immediately following the scene entitled "Maps" in which the rihla, the pilgrimage account, is described, Brand begins a long narrative of her own pilgrimage to Africa although, unlike Hartman, she does not make it to the Slave Coast. Entitled "Voyage," this long narrative is the throbbing heart of the 
book and describes Brand's thwarted attempt to get close to the Door of No Return. During her long plane journey from Frankfurt to Johannesburg, Brand meditates on her relation to the Door. Surprisingly perhaps, during the plane ride she reads André Gide's travel writing about the Congo and Chad. It is from inside the plane that Brand is the closest she has ever been to the Door, and yet she can only imagine it below her, still so far away.

For over eighteen hours Brand keeps a half-crazed vigil as she passes over the continent, obsessed with tracking the progress of the plane across the electronic map. She cannot relax or sleep: "how can I, crossing Africa? I want to feel it even if I am miles above in the sky, even if I cannot see. I am all nerve and energy at the thought of the great land below" (Map 89). The speaker has never been to the African continent before, though of course she has imagined it: "The idea of return presumes the certainty of love and healing, redemption and comfort. But this is not return. I am not going anywhere I've been, except in the collective imagination" (90). She cannot help but think about her ancestors' own journey: "Moving through dark air or dark water, it is the same. I cannot help thinking, I at least know where I am going. I am going willingly” (88). Most compelling to her is the thought of her proximity to the Door of No Return: "I am crossing the place which holds it; the place which holds the before of history. It is a return, but aptly it is in the air and it is a glancing pass at the Door of No Return. The door is not on this map. The door is on my retina" (89). Brand does not go near the slave castles of West Africa on this journey--she is unable to get even remotely close to the Atlantic coast: even when the plane lands temporarily in Kinshasa, the passengers are forbidden to disembark due to "political conflict" (91). Brand describes feeling 
devastated: "This opening, which I had hoped to observe, remained compelling though concealed. But why so compelling?" She wonders if the Door is "the Holy Grail of the Diaspora" because it is the trophy that everyone seeks, the pinnacle of the quest, and the wished-for cure for loneliness that will "transform us into being" (93). Although she comprehends that the Door is metaphor, she nevertheless feels its physical "beckoning" (93).

Ultimately, Brand is prevented from having an immediate encounter with the Door of No Return and yet, as this section of the book underscores, perhaps the physical encounter is not necessary, since the Door itself exists fundamentally in the imagination. Despite not disembarking from the plane in Kinshasa or detouring to the Gold Coast, Brand nevertheless engages in a deep meditation on the Door, the captives who were thrust through it, and her own relationship to it. For those in the diaspora, the ambiguity and the paradox of the Door persists: "The door, of course, is not on the continent but in the mind; not a physical place--though it is--but a space of the imagination" (96-97). Because the Door exists in the imagination, so too must the concepts of return and homeland exist in the imagination. Ultimately there is no other home, other than in creation, in the imagination, and in the words of poets. Like Kamena in At the Full and Change of the Moon, Brand can only keep searching for what she thinks will set her free. In contrast to Brand, Hartman physically encounters the Door of No Return, and yet her engagement with it is unsatisfactory and underwhelming. During her time in Ghana, she visits the dungeons of Cape Coast Castle and the famous Elmina Castle. Elmina, the massive Portuguese and later Dutch-held fortification built on the Ghanaian coast in 1482, was erected as a storehouse for trading goods but eventually housed the 
European slave traders as well as their captives until they were shipped across the Atlantic. The castle is all that remains of Elmina's past status as the "gateway between the African hinterland, the entrepôts of Western Europe, and the plantations of the New World" (Hartman 52). Hartman had come to Ghana for her research because the country "possessed more dungeons, prisons, and slave pens than any other country in West Africa" (7). Her intention was to "retrace the process" that led from capture to slavery, and thus visiting the holding cells and dungeons of Elmina Castle and Cape Coast Castle was part of her itinerary.

In Lose Your Mother, the experience at Elmina is narrated as personal reflection, and Hartman weaves historical facts and information in and around her bewilderment, frustration, and anger. Not heeding the voice in her head warning her that "there is nothing here for you" (49), the author describes feeling disturbed by how little the city acknowledged its slaving past: "I recoiled from the whirl of life spinning about me and threatening to pull me under [...] I had remembered the town as a graveyard, so I was disturbed by the greetings shouted back and forth between market women and the peals of laughter" (50). She is shocked by the vigour and vibrancy of the young women at the market stalls: "It was to my eyes a terrible beauty. It didn't seem right that this prodigal and teeming display of life brushed against the walls of a slave warehouse and failed to notice it" (50). No attempts to remember or pay homage to the slavery past are evident in the town. Hartman harbours fantasies to "deface" the castle, burn it down, destroy it in some way as if to belatedly take her revenge against the now-dead masters and merchants. She writes that "Now it was too late for retribution $[\ldots]$ Those I wanted to harm were not within my reach. Those I wanted to rescue were gone" and, in addition to 
being unable to rescue the victims, Hartman is powerless to take revenge on the winners of the slave trade, "the banks, shipping companies, insurers, nation-states, manufacturers, and ports [that] still thrived" (55) that are still profiting from slavery.

Despite her inability to avenge Elmina's past, the author is disappointed and offended that life around the Castle carries on as if ignorant of its history: "Monuments, like graves, are intended to preserve the dead and to suspend the past. But everything I could see refuted this. I still thought of this castle as a tomb, but if it were, then where were the mourners? Didn't a gravesite require the company of the bereaved?" (70). The local people, including her colleagues at the university, are not interested in Elmina's slaving story, never bothering to take a tour of the castle or the other coastal forts. Her friend, the Ghanaian poet Kwadwo, says that "We, as Africans, are ashamed for our participation in the slave trade, and for this reason are unwilling to talk about the very issue that brings most of you here. And on both sides there is ignorance and a failure to understand one another's lives" (73). Hartman understands this to be his explanation for why "there weren't any mourners" (73), and she worries her presence is not enough.

Hartman herself can only mourn from a distance at Cape Coast Castle, the Britishbuilt dungeon just ten miles from Elmina and designed as a warehouse for slaves (110). There the slave pens were built underground in order to prevent rebellion. Alhough the underground dungeons resembled tombs just as the slaves themselves soon resembled corpses, the Royal Africa Company and the Company of Merchants considered the Cape Coast dungeon "a womb in which the slave was born $[\ldots]$ The miracle of the slave trade was that it resuscitated useless lives and transformed waste into capital" (111). For his part, Césaire highlights this same contradiction in the Cahier when he describes the 
slaves as "walking compost hideously promising tender cane and silky cotton" (Césaire qtd. in Hartman 111). Similar to how Philip describes her motivation in ZONG!, Hartman writes that she "wanted to give the dead their due" and make a meaningful connection with the victims but that she did not know how, since not even the dungeon offered clues, stories, or information about the lives that were lost: "Even in the museum, the slaves were missing [...] Nor was their family life and social organization described. How they farmed or fished or appealed to their gods or buried their dead goes unmentioned. The museum was as bereft as the underground" (116). In an echo of the social prohibition to identify a slave, the museum simply ignored the lives, cultures, and pasts of the people who became slaves; their origins as humans were not worth exploring.

The author writes that she desperately wanted to feel a connection to those who had been held captive here: "Each time it was the same. I failed to discover anything. No revenants lurked in the dungeon. The hold was stark. No hand embraced mine. No voices rang in my ears" (118). Had she experienced the physical touch or supernatural presence of the slaves as she wished, perhaps she could have better understood her own identity as a diasporic subject: "I, too, was a failed witness. Reckoning with my inheritance had driven me to the dungeon, but now it all seemed elusive. I struggled to connect the dots between then and now and to chart the trajectory between the Gold Coast and Curaçao and Montgomery and Brooklyn. But I kept fumbling” (129). The presence of the lost slaves, like the missing information in her own family history, including her Curaçao family's Sephardic Jewish ancestry, eludes her. Only their absence is felt: "Love longed for an object, but the slaves were gone. In the dungeon, missing the dead was as close to them as I would come" (135). Hartman desires tangible evidence, but the stories and 
identities slip through her grasp.

Like Brand, Hartman lacks certainty about her origins. She writes that "the predecessors of my grandfather Frederick Leopoldo were spectral figures. All I knew about my great-grandfather was that he had been a prosperous Jewish merchant" (81). Hartman describes discovering, in the Curaçao archives, that legally her grandfather's given last name was Maduro, his mother's name, rather than Hartman. In Curaçao, Maduro is the name of the most prominent Jewish merchant-class family, a family with ties to the island's sugar industry, and the name holds prestige to this day. The author's grandfather thus likely had at least one Jewish parent, no matter how mixed the bloodlines. And yet Hartman does not dwell on this angle. Her grandfather is remembered as a polyglot merchant seaman who had "embraced errantry" (98). The author writes that "[her] grandfather had discovered years back that the only home he would ever know was the imagined country, the promised land of the heart, the territory of dreams. He accepted the peril and promise of being without a country. It explained why, as much as he spoke of Africa, he never imagined it as his natal land" (99). Hartman writes that her grandfather was not preoccupied with tracing his ancestry to Africa or with dwelling on diaspora: "the route he charted back and forth across the Atlantic, as a young seaman aboard a merchant ship, was an adventure, a detour, not a return" (99). Nevertheless, the author herself "can't believe that as he listened to the rumble of the ocean he was unmindful of that other crossing" (99).

Neither Hartman nor Brand experiences the Door of No Return as expected. Their dissatisfaction reveals the impossibility of an easy "return." As the name of the Door underscores, no return is possible for the diasporic subject. And yet the diasporan cannot 
help but feel compelled to engage and connect. Hirsch and Miller describe return as not only "a desire to map a loss" but also an attempt at "acknowledgment" (18). In all cases it involves the mobilizing of the imagination to different ends: "a counterfactual effort to imagine a world before disaster and displacement [...] a claim to justice and restitution or, for others still, a form of memory tourism" (18). Despite their initial dissatisfaction, both Brand and Hartman encounter the Door through "acts of imagination" which are narrated in their texts, and those acts "can also become an act of repair, however tenuous" (18). While their memoirs fly in the face of Henry Louis Gates Jr.'s "return to Africa" TV specials, as well the various West African tourism offices that promise to diasporan Americans that they will find their "roots," Brand and Hartman do not deny the importance of this quest. The Door of No Return, no matter how elusive, compels their narratives but also sustains their artistic practice with the potential of tentative repair. Whereas an international truth and reconciliation commission for the slave trade and the crime of slavery is impossible, nevertheless the authors offer poetic commissions of truth-telling in which mourning for undocumented losses can be read and therefore heard.

Ultimately Hartman realizes that her connection to Africa, as an AfricanAmerican, can never be to the descendants of the slave traders (who are indifferent to the descendants of slavery and still resentful that the Europeans paid them in valueless trinkets--cowrie shells--for their trouble) or to the actual slaves themselves (to whom a connection is impossible after so long and because their lives before slavery were obliterated). Instead, she finds a connection with the communities who struggled to escape and free themselves from slavery. Hartman finds a community in Ghana that was founded by people on the run from slavers, similar to the maroon communities of ex- 
slaves in the Caribbean: the village of Gwolu is one of many such communities in West Africa that actively resisted the slave trade. As an act of remembrance for what they had lost and then found, "the fugitives and refugees and multitudes in flight were called the Sisala, which means 'to come together, to become together, to weave together'“ (225). Gwolu was founded by a band of fugitives who were offered protection and community by an existing village; by banding together for protection, they struggled for years to defend themselves against the invaders. Their town was built up into a fort protected by seven walls, trenches, and armed guards with poisoned arrows to secure the maroonage. The townspeople still tell stories and sing the songs of their glorious and unexpected triumph against the most infamous trader and raider of all, Babatu.

Hartman writes that at first she dismissed these songs and stories, feeling no possible connection to the victory of Gwolu's inhabitants: "Their story of slavery was a narrative of victory, a tale of resistance and overcoming, in which the captives had been banished. Even its sounds were strange to my ear, war chants and military songs rather than dirges, field hollers, and sorrow songs" (233). Unlike them, her African-American history felt like one of defeat, of incomprehensible loss. But then she remembered that the triumphs of Gwolu were won after exile in the savanna, solidarity, battle, and centuries of ongoing resistance to slavery. Hartman realizes that although the history of the Sisala was different than the history of her ancestors, their fight to defeat the masters was the same fight that motivated the descendants of slaves in the New World, from maroons to civil rights activists. Gwolu, in fact, was evidence of the "freedom trail" her friend and interlocutor John had challenged her to find when she first arrived in Ghana: "Every step you take in Ghana crosses the trail of slaves. It's not hard to find a slave 
route. It's the freedom trail you should be looking for" (27). The author recognizes, finally, that there is an African legacy of resistance that she could claim as her own: "The legacy that I chose to claim was articulated in the ongoing struggle to escape, stand down, and defeat slavery in all of its myriad forms. It was the fugitive's legacy” (234). She admits that "If after a year in Ghana I could still call myself an African American, it was because my Africa had its source in the commons created by fugitives and rebels [...] It was the dream of an elsewhere, with all its promises and dangers, where the stateless might, at last, thrive" (234). Hartman's Africa, then, is one in which the histories of the slaves and the maroon fugitives might be honoured and their hopes for freedom realized. The final passage of the book offers a small gift to the author and the reader. In Gwolu, the author comes across four girls jumping rope and singing: "Gwolu is the town of gold / When you enter the circle / You will be protected / You will be safe" (235). The young man next to Hartman translates for her: "The girls are singing about those taken from Gwolu and sold into slavery in the Americas. They are singing about the diaspora." For Hartman, this song is the belated answer to her quest, the elusive connection, finally, to the captives who had been turned into strangers and forced to pass through the Door of No Return: "Here it was--my song, the song of the lost tribe. I closed my eyes and I listened" (235). The song comes late, and it does so only after a shift in Hartman's own expectations. And yet it does come, and she finds it heartbreakingly soothing, like balm, like salve. 
Despite their different approaches and contexts, both A Map to the Door of No Return and Lose Your Mother bring to fruition the preoccupations of the dissertation as a whole. With their attention to formal and aesthetic characteristics, emotional engagement, and archival interrogation, the two works embody an attention to maroon witnessing and to a careful representation of historical atrocity. Thematically, both works confront the risk that, for the diasporic subject, belonging and the dream of return may be impossible. In their non-conventional, queer ways, the authors emphasize the importance of stories and storytelling equally for the victim, the witness, and society at large. Although "we cannot pretend that literature or literary studies $[\ldots]$ rises like an answer to the problems of human rights violations" (McLennan and Slaughter 7), literature can contribute to a long-term, complicated process of engagement, without which traumatized individuals and societies cannot move forward.

However, as my discussion of A Map to the Door of No Return and Lose Your Mother demonstrates, the losses of diaspora must also be acknowledged, not disregarded in favour of the seductive hope of healing. While Brand's speaker finds solace in the poetic, including in the works of the other writers who accompany her on her journey, she is nevertheless alone with her loss, unable to find belonging, hovering above and around the Door of No Return that she cannot reach: "I know that if I go to that place I will be destroyed. Its photographs take my breath away" (Map 223). Hartman ultimately finds community not through a fulfilling fantasy of return but, rather, through accepting its opposite: by confronting her status in Ghana as a stranger who has lost her mother and therefore her familial and social heritage, the author discovers communities of fugitives who had escaped slavery. While Hartman finds inspiration in examples of historical 
African maroonages, Brand's poetic flight is itself that of a maroon: as her words search for textual freedom and home among all that has been forgotten, the memoir becomes a queer compass to the diaspora, one pointing to the need for new articulations of what belonging could be.

Notes

1 "Where the stateless might, at last, thrive" (Hartman 234).

${ }^{2}$ A useful overview of the field is Allen's introduction to GLQ: A Journal of Lesbian and Gay Studies entitled "Introduction: Black/Queer/Diaspora at the Current Conjuncture." Notable books include E. Patrick Johnson and Mae Henderson's Black Queer Studies: A Critical Anthology which collects many of the papers first presented at the 2000 conference organized by Johnson at the University of North Carolina at Chapel Hill. Also worth noting are José Esteban Muñoz's Cruising Utopia, Roderick Ferguson's Aberrations in Black: Toward a Queer of Color Critique, Thomas Glave's Our Caribbean: Gay and Lesbian Writing from the Antilles, Omise'eke Natasha Tinsley's "Black Atlantic/Queer Atlantic" in GLQ and later her book Thiefin' Sugar: Eroticism Between Women in Caribbean Literature, and Michelle Wright and Antje Schuhmann's Blackness and Sexualities. Jennifer DeVere Brody and Dwight McBride edited a significant special issue of Callaloo 23.1 (2000) entitled "Plum Nelly: New Essays in Black Queer Studies." This issue includes an annotated bibliography by Nicholas Boggs: "Queer Black Studies: An Annotated Bibliography, 1994-1999."

${ }^{3}$ Gloria Anzaldúa writes that "[white middle class lesbians and gays] have produced queer theory and for the most part their theories make abstractions of us colored queers [...] Their theories limit the ways we think about being queer" (251). Nikki Sullivan writes that "even postcolonial accounts of diasporic subjectivity can and do fall prey to modernist logic with its singular fantasies of cultural and political progress: fantasies, which at least implicitly, all too often structurally exclude queer bodies" ("Queer Race" 74-75). Significantly, Gopinath writes that it is the queer female subject who is "the crucial point of departure in theorizing a queer diaspora" (Impossible Desire 16).

${ }^{4}$ In Human Rights and Narrated Lives Schaffer and Smith examine how the legal system can sometimes use narrative as legal evidence.

${ }^{5}$ The period of the failed socialist revolution in Grenada and the related American invasion of the island haunts the whole of Brand's oeuvre, as I argue in this dissertation's first chapter. A new book by David Scott examines the repercussions of the revolution: Omens of Adversity: Tragedy, Time, Memory, Justice.

${ }^{6}$ For more about the queer artist figure in Brand's oeuvre, please see my discussion of Tuyen in "Fugitive Rhythms: Re Imagining Diasporic Caribbean-Canadian Communities in Dionne Brand's What We All Long For" in The Caribbean Woman Writer as Scholar. In that essay I discuss the potential of diasporic art to imagine new possibilities: "If to live in diaspora is to live the experience of being away, of being displaced, then perhaps it is through art that we can attempt to lead ourselves, if not home, then elsewhere" (408). Additionally, please see Jennifer Blair's treatment of queer youth in Brand's work in the article "The Queer Racing of Children in Dionne Brand's What We All Long For" in Studies in Canadian Literature.

${ }^{7}$ Hartman feels equally alienated among her academic colleagues who do not quite know what to do with her African-American heritage, and she suffers because of their embarrassment and discomfort: "The research group [...] was composed of professors, lecturers, and graduate students from Benin, Cameroon, Gambia, Ghana, Kenya, Nigeria, South Africa, and Uganda. A pattern of collegial joking and teasing had developed over the course of our first weeks together. Ninety percent of the remarks began, 'You South 
Africans,' 'You Nigerians,' 'You Ghanaians.' But whenever I entered the circle I was greeted by an awkward silence [...] My presence tainted the glory of precolonial Africa. I was the disposable offspring of the 'African family,' the flesh-and-blood reminder of its shame and tragic mistakes" (214).

8 "For Baba, slavery was a scheme for generating revenue for his country. He had organized the International Roots Homecoming Festival to draw African-American tourists to Gambia. For Jeffery, it was a way of getting a fellowship to the States [...] For Jenks, it was what Europe had done to Africa" (215216).

${ }^{9}$ Hartman describes the indifference and lack of compassion showed by many West Africans to the diasporic descendants of the slave trade. African-Americans are seen as obruni whose tourist dollars are appreciated, but who are often treated with resentment. The author describes a common Ghanaian joke that represents the assumption that the African slaves who ended up in America "got a good deal": "In Ghana, they joked that if a slave ship bound for America docked off the coast today so many Ghanaians would volunteer for the passage that they would stampede one another trying to get on board [...] what they didn't understand was that many of us also lived in poverty. (It didn't look the same, but the assault of poverty was life threatening in the United States too)" (170).

${ }^{10}$ Please see Chapter Two of this dissertation for an extended treatment of zombification and dezombification and its relation to slavery. 


\section{Conclusion}

\section{Create Dangerously}

Poetry is here, just here. Something wrestling with how we live, something dangerous, something honest.

Dionne Brand, "Poetry" Bread Out of Stone (196)

Create dangerously, for people who read dangerously. This is what I've always thought it meant to be a writer. Writing, knowing in part that no matter how trivial your words may seem, someday, somewhere, someone may risk his or her life to read them.

Edwidge Danticat, "Create Dangerously" Create Dangerously (10)

In this dissertation, I have brought into conversation contemporary works by

Caribbean women writers who live in the diaspora but return to the past and present of the archipelago and to the un-redressable crime of slavery. These writers engage in a contemporary struggle inspired by that of the historic figure of the maroon, but here the writers are preoccupied with cultural enfranchisement and literary self actualization rather than with armed rebellion. Their literary landscape is marked by the wounds of slavery, and accordingly the previous chapters have woven together postcolonial criticism with scholarship interested in human rights in order to contribute to a decolonizing of trauma studies that honours the history of the region and the memory of its peoples. In many ways the dissertation seeks to do justice to a history of difficult stories without disgracing the dead or the survivors; methodologically as well as thematically, the dissertation is thus preoccupied with this human rights paradox, as are the innovative literary works under examination. Overall the project reveals a complex connection between genre and ethics as the texts pursue a poetics and politics of decolonization. In the literary works examined here the invocation of the maroon trope allows for a physical yet engaged distance, and the works' formal structures convey the difficulty of capturing, testifying to, and representing stories that cannot easily be told. 
The writers studied in this dissertation are nomadic maroons who crisscross the world, and they all grieve for the wreckages of the past as they try to imagine a different future. Because grief is a stage in the process of mourning, and mourning can help with healing, surviving, and living, grief is therefore productive and creative. The potential of political enquiry, dissident action, and defiant outrage can be born from loss; "something," indeed, can come from "tarrying with grief" (Butler, "Violence, Mourning, Politics" 30). In the essay "Our Guernica" in Create Dangerously, Danticat writes about the aftermath of the 2010 earthquake in Haiti as the moment everything changed for her and her people: "Would there be any poetry amidst the Haitian ruins?" she asks, evoking Adorno (159). ${ }^{1}$ What is the role of the diasporic maroon witness when tragedy hits in the place of origin? When human suffering and violations of human rights occur in the present, is the role of the maroon witness different from when she witnesses events that happened in the past? In each case, the responsibility is to bear witness, to take in testimony, and then to share it outwards. Danticat attempts to articulate this position: "Maybe that was my purpose, then, as an immigrant and a writer--to be an echo chamber, gathering and then replaying voices from both the distant and the local devastation. Still words often failed me" (159). "To be an echo chamber," then, is Danticat's articulation of the work of bearing witness. While some horrors are recent, like the earthquake in Haiti and its aftermath, some are hundreds of years old, like slavery or the massacre on the Zong. And yet the work of the witness is ongoing, and the sounds in the echo chamber need always to resonate and be heard.

Danticat explains that "from now on, there will always be the Haiti of before the earthquake and the Haiti of after the earthquake. And after the earthquake, the way we 
read and the way we write, both inside and outside of Haiti, will never be the same" (162). Despite it all, the author remains resolute that the need to write and to echo back will not change: "Perhaps we will write with the same sense of fearlessness or hope. Perhaps we will continue to create as dangerously as possible" (162). However, she underscores the deep impact of chronic suffering: "our muse has been irreparably altered. Our people, both inside and outside of Haiti, have changed. In ways that I am not yet fully capable of describing, we artists too have changed" (162). The diasporic artist and maroon witness, then, writes from a distance lòt bò dlo, but is always connected to the past, sometimes painfully. ${ }^{2}$

For Danticat, to create dangerously, to write dangerously, to remember dangerously involves "creating as a revolt against silence" ("Create Dangerously" 11). When the maroon witness takes on the task of testimony, she does so in order to bear witness to the suffering of others; no matter the outcome, no matter the danger of the memory, human dignity is in some way restored because of her ethical engagement. As a symbol of his own inside/outside diasporic position of victim and survivor, the Shoah poet Paul Celan's resolute use of German represents his diasporic position of inbetweenness, loss, and hope. Celan clings to the power of language and poetry "so as to speak, to orient [himself]" in time and space, because he himself has lost both time and space ("The Bremen Speech" 112). For Celan, language remained all he had "in the midst of the losses," but it had to undergo a difficult journey "through the thousand darknesses of deathbringing speech." A poem "seeks to reach through time" and, like "a message in a bottle," is conjured "with the belief that somewhere and sometime it could wash up on land, on heartland perhaps. Poems in this sense too are underway: they are making 
toward something" (112). For writers whose countries and people have disappeared, or who have lived in the unsettlement and uncertainty of diaspora or exile, writing poetry can be a life raft and a message in a bottle, infused with those associations of potential, safety, survival, rescue, and a life on the other side. When a poem washes up on shore, it can become someone else's refuge, his connection to another world, her maroonage. Ultimately the texts I have examined here suggest that literature and poetry can be a lifeline.

Danticat invokes this same sense of connection between writer and reader when she writes that "somewhere, if not now, then maybe years in the future, a future that we may have yet to dream of, someone may risk his or her life to read us. Somewhere, if not now, then maybe years in the future, we may also save someone's life, because they have given us a passport, making us honorary citizens of their future" ("Create Dangerously" 10). And yet, as with the memoirs to un-belonging discussed in Chapter Four, liberty is always tinged with the taste of what is lost, and finding a safe maroonage, a safe community, is sometimes elusive, so that one is always hovering above and in-between, always in un-belonging.

In closing, I would like to turn from Germany and Haiti onwards to Martinique through a discussion of Césaire's Cahier d'un retour au pays natal, in honour of this long poem's position as a touchstone for my project. The Cahier is not exclusively a long poem about Négritude, for all its undisputed importance as a seminal Négritude text, but it is also an example of a diasporic memoir by a maroon witness. Composed in Paris when Césaire was a young student, the poem is full of nostalgia and longing for his home island of Martinique, as well as longing for a home more historically distant in Africa. In 
the Cahier, first published in 1939 after Césaire's life-changing time in France in the company of Léopold Senghor and Léon Damas and their work on L'Étudiant noir, Césaire articulates both the love he feels for Martinicans and his frustration at their subjugation by the French with his war cry: "ASSEZ DE CE SCANDALE!" (32). The long-poem / memoir follows the speaker's own prise de conscience, and this movement to self and social awareness is the poet's recommendation to his people.

The Cahier is a call to arms, a summons to Martinicans to raise themselves from their lying-down, horizontal position in the "boue" (mud) of colonial oppression, and assert themselves as standing, dignified human beings, finally "debout" (upright, standing). The poem's structure, rhythm, and stanza delineation illustrates the movement from horizontalness to ascension and verticality. The poem's central image of a tree, rooted down strongly in the ground of Africa but able to stand on its own, emblematizes the poet's call for cultural independence. Césaire's dream is to find himself at one with his renewed people and country, and for the people to be united in a collective declaration: "Et elle est debout la négraille [...] debout / et / libre" (61-62). ${ }^{3}$ Ironically, although the Cahier would become a popular manifesto for independence movements around the world, Martinique has never shaken the paternal guardianship of France. Nevertheless the Cahier exemplifies the maroon witness task of literary revolution in order to contend with the cultural legacy of the crime of slavery.

Like the works of maroon witness examined in the previous chapters, the Cahier interweaves life-writing, historical essay, haunting fictionalized prose, and elegiac poetry. The writers examined here cannot, other than by fragmentation and formal resistance, represent the experience of diaspora marked by rupture, injustice, hardship, trauma, and 
horror. These writers are indeed poets of extremity whose temporal distance from the human rights atrocity of slavery paradoxically allows for a deep, intimate engagement with the crime. As maroon witnesses, they engage with the legacy of slavery and colonialism in order to promote a decolonization of the present, and it is in their writing that the radical defiance takes place.

If modernity's forces of colonialism, immigration, migration, and diaspora have led to a "deterritorialization of culture" which, in turn, "has produced an urgent need for new narratives of belonging" (Casteel 192), then easy identifications with either New World geographies or places of origin can no longer be enough for diasporic writers. Yet writing and reading do not require passports, and seen in these terms poetry, literature, and art may offer opportunities for meaningful engagement and connection. The works treated in this dissertation are urgent explorations of art, and they just as urgently confront the role of the witness to bear the burden of testimony and transmit it. Spanning the massacre onboard the Zong, the bombings of the Iraq War, the Irish Potato Famine, spiritual starvation in a Parisian psychiatric hospital, the Duvalier regimes of terror, and the dungeons of Elmira and the Door of No Return, the books journey across time and space to show that loss and suffering are ongoing, and that the dehumanizing legacy of colonialism, slavery, and indenture still looms large.

Much in the same way that the texts are concerned with the past as well as the present, they are local as well as global. The figure of the maroon and the tradition of maroon resistance is a productive paradigm for Caribbean literary scholarship because it too is simultaneously local and global, indigenous and diasporic. Similarly, attention to vodou as a literary framework, in lieu of relying on the postcolonial gothic as a frame for 
narratives about spirituality, offers an opportunity for complex conversation about trauma and human rights studies. The Caribbean tradition of the maroon takes on new meaning in contemporary literature by women: no longer just the invocation of resistance to slavery and perilous flight to the mountains, here the maroon figure and the strategy of maroonage is taken on by the generic wrestling of the texts themselves--texts that confront the limits of the long poem, postcolonial gothic novel, bildungsroman, and memoir--and by their presentation of political dissent, justice, belonging, and loss. By engaging with the tradition of the maroon, the contemporary diasporic writers studied here engage in non-physical but engaged literary resistance that contributes to a retroactive post-slavery truth and reconciliation commission of inquiry. From the metaphorical hills and mornes of the diaspora, the writers bear witness to what they observe below them and seek a different kind of home and refuge in a politics and poetics of decolonization.

\footnotetext{
Notes

${ }^{1}$ Danticat describes post-earthquake Port-au-Prince as a war zone: "Grand Rue, downtown Port-au-Prince's main thoroughfare, looks as though it had been bombed for several consecutive days. Standing in the middle of it reminds me of film I had seen of a destroyed Hiroshima" (164).

${ }^{2}$ Here again I aim to highlight my project's understanding of Haiti as an important cultural and intellectual node.

3 "The children of negritude stand tall. Tall and free" (Césaire 61-62).
} 


\section{Epilogue}

\section{Notes From a Return to the Native Land}

During the writing of this dissertation, frequently my fingers have typed out $s-a-l$ $v$-e instead of s-l-a-v-e. I notice it along the way as I type, but even in the printed drafts sometimes $s-a-l-v-e$ appears like a ghost, like a whisper. Salve is an ointment, a medicinal balm. "Salve" reads like a comforting warm cloth on burning eyes. But there is nothing comforting in these histories. How can I find any salve in the transport and captivity of hundreds of thousands? My fingers throb. My eyes sting.

My brother and I played a strange game when we were children. We would hold out our arms and compare their colour. Then someone would be the slave auctioneer and decide which one of us would be sold or freed. I was always sold. He was always freed. Dark knowledge to a child. (The second version of this game involved deciding who would be sent to the concentration camps for looking Jewish. Here too, I tended to lose.) I knew with as much conviction that "skin coloured" Band-Aids, ballet leotards, and crayons would never match me. My skin was "dirty coloured," said my childhood friends: "No, where are you REALLY from?” Dany Senza's first novel, Caucasia, is like an animal caught in my throat. It is a variation of my story: two sisters, one who passes as white and one who passes as black. I recognize it. I read it fearfully. "WHAT are you, exactly?"

If there is anything I know for sure about being mixed-race, it is that no matter how you self-identify, someone else will have a different idea about who you are and be only too willing to tell you what they think. In some contexts, my blue-green eyes and light brown hair mark me as white, though my hair's frizz and curl begs questions; in 
other contexts my skin colour is noted suspiciously as "perpetually tanned," "olive," “dark," "swarthy." I have been described as "Middle Eastern," "Lebanese," "Turkish," "French," "Jewish," "Arab," "Brazilian." No one can ever guess the exact combination of what I am, the exact miscegenation equation that resulted in my features, but generally the most common description is that I look "exotic," "ethnic," "unusual." ("Where are you from?" That is the question that usually follows every new encounter).

The truth is I am mixed--some tenuous variation of black and white, with other mysterious angles like Ashkenazi and also Sephardi Jewish, Indonesian, Carib-Arawak, et cetera. I fantasize about doing one of those DNA tests and seeing the results, in part hoping that my request breaks the machine: but what a disappointment if it came back reading, simply, as white? Because that is truly the denomination I least want to have to own up to fully. Does everything eventually distill to white? Or to brown? Or to personal interpretation?

Context is everything: location, location, location. In my case, identity depends on what is mainstream where I happen to be. I have always felt very at home along the southern shores of the Mediterranean. In Lebanon, Israel, and Sicily I am not unusually Semitic looking. I am spoken to in Arabic, Hebrew, and Sicilian, and the shop-keepers laugh out loud when I tell them, "No no, I am a tourist." I find their conviction comforting because usually, at home in Ottawa, Canada, I just feel different. Not even my brother looks like me, and so I feel alone at the mercy of people's stares, judgments, and categorizations. The short form answer, that my parents are French and Dutch, convinces no one. I say it slyly, holding everything back. 
When I arrive in Martinique in the spring of 2013 I am conscious that I look like a tourist. My skin is pale like winter: when I left Ottawa, it was -2 C, so summer hadn't come yet to warm my colour. I land in Martinique and I know I look white. Touristwhite. How long will it take for the sun to darken me to a less noticeable shade of brown? But even still, I think, I can never look black. I am not black enough. Always, in each category, I am different and other, never quite enough.

This belonging and unbelonging is the tight-rope I walk in other aspects of my life as well. Where do you belong when your homeland is somewhere across the seas and in the past, when you live in a society that looks different than you do, when you live with a foot in at least two places, separated by a gaping schism? Who are you, who can you truly be, if you are defined, and not always the same way, by other people? A kind of schizophrenia can set in, an uncertainty that other mixed-race people will recognize, but likely that those fully settled in their identity will trivialize as a waste of time.

"You just are who you are. What's the big deal?"

"You're too sensitive. It doesn't matter."

"You're mostly white anyway."

Or, paradoxically: "This country isn't racist. Canada is a Multicultural Society."

In Martinique one day, Marie-Hélène's adopted daughter, 6-year old Judith, called me "Tatie." Auntie. Her mother corrected her: "Chérie, ce n'est pas Tatie, c'est Sarah." But I couldn't help but wonder if it was because the little one thought I looked enough like Marie-Hélène to be related. To be her aunt. And although Marie-Hélène dismissed it quickly, smiling indulgently, and Judith went back to devouring her pain au chocolat, I realized that I had been desperate for what Judith had just given me: recognition. That 
acceptance and recognition that I could belong here, could live here, could be from here. I use "could" on purpose because I believe that belonging and living must always be conditional, tenuous; we in the diaspora are never of a place anyway, can't seem to belong anywhere, even less so when we are mixed and our origins hard to tell. But even this "could," even the recognition of familiarity from a small child, was enough to make me swoon. I would have held Judith's small hand all evening if I could have stayed with her there in that boulangerie in Rivière Salée.

Marie-Hélène is decidedly antillaise. She walks the walk, toned legs atop delicate heeled sandals. The "Créoles" earrings in her ears are shining gold hoops. Her accent, her Creolophone accent from her commune of Rivière Salée, is soft, quietly musical. We have similar hair: soft curls, her colour more reddish than mine maybe. We have the same skin, hers maybe darker than mine from the constant sun, but just a shade of difference really and what look like tan marks around the neck of her shirt. My eyes are that indefinite blue while hers are brown. Does this coloration make her a chabine? A mulatresse? Antillaise decidedly. I learn later that her father is white from France and secretly Jewish, and that her mother is a négresse. If I look like her, what does that make me?

Children are more perceptive, surely, than adults are. They give us signs we can choose to take or ignore. I think Judith must be right: Marie-Hélène and I sort of looked related. And so from the recognition in the shining-eyes of this little girl I feel, finally, accepted. Is this desperate need of mine to find kinship in Martinique understandable or pathetic? There aren't even any direct cousins of mine living here that I know of, although Boris assures me that there are other Zizines. That name is my Martinican 
pedigree, and it has a certain cachet despite its slave heritage. The caché comes, on the one hand, from being authentic and local, and on the other hand because of some key events. When I first admitted it to Boris to explain a bit more about why I was here in Martinique, he said: "En plus, Zizine." As if that name above others counted for something. Recognition. Kinship. Acceptance.

Hartman writes that when a person was captured into slavery he literally, politically, and socially lost his mother, her ties of kinship, his place in the community's social order. The West African word for slave meant stranger, one without family. To then pass through the slave castles on the coast, be pushed through the Door of No Return, and be thrown onto a slave ship, made all those former ties even more impossible to recover. Those who made it to the Caribbean shores had to start over, make new families, invent new names like Zizi and Zizine.

Boris is ever the professor: did I know G. B. Mauvois's 1999 book about Louis des Étages, the man who was assassinated along with Charles Zizine, my grandfather's brother? Did I know that in Ducos, the commune in which they were killed, the Main Street had been renamed in the politicians' honour: "Rue Zizine et des Étages"? Boris took me to Ducos with Marie-Hélène yesterday. We walked along the Main Street, and I worried there would be no street-sign to photograph: I needed that as a memento mori and, I think, as proof of something. It was a vibrant street: round green hills and rich fields unfolding behind the school; brightly painted community centre, children in school uniforms meeting their parents, little shops. It's a quiet little bourg: I liked the ramshackle créole-style houses with their friendly faces and broken shutters. I took photos and 
wondered if these buildings had existed when Charles Zizine had lived here, and I wondered if my grandfather had ever been here to visit his brother.

We went to the Mairie, explained our request, and the secretary walked with us along the side streets to the village library. By serendipity we met the mayor on our way, and I was introduced as the grand-niece of Charles Zizine. I sheepishly explained that his brother Pierre had had ten children and that I was the daughter of his youngest, hence why I could be related to someone killed in 1924. The mayor smiled, shook my hand, and urged me to return again. Recognition or the generosity of a politician? In the library the same welcome: "Let me get out the exhibit we made for the commemoration. Let Monsieur find the video we did of the re-enactment, we did a commemoration did you know?" All this even though we arrived late, quite near to closing time.

"How come you are living in Canada?" the secretary asks me.

“Why don't you live here, Tatie?" Esther asks me.

In Brand's A Map to the Door of No Return, the Trinbagonian-Canadian poet laments that we in the diaspora can only ever know for sure that we are from a place other than the one in which we live. My autographed copy of this book has travelled with me like a passport: it is thumbed through, dog-eared, underlined in pencil and ink, the pages now nearly all wrenched from their spine. The book holds memento from my own travels (dried bougainvillea petals, a leaf from a lime tree, a flyer from St. Maarten). The inscription on the front page, by Brand, reads: "For Sarah, to travel without a map. Dionne Brand 2007." In the first pages Brand describes asking her grandfather where their family was originally from: "Yoruba? Ibo? Ashanti?" Her grandfather could never remember. She writes: "We were not from the place where we lived and we could not 
remember where we were from or who we were" (5). "Pourquoi tu n'habites pas ici, Tatie?" asks Judith, between the crumbs around her smiling mouth.

I have some documents to prove my ancestry, but they only go back as far as the end of slavery in Martinique. Going back further with any certitude is impossible. There are Enfranchisement records dated 1833 from the commune of Le François Martinique, recording the freedom of "Benjamin dit Zizin, mulatre" and later the freedom of his wife Béatrix, "négresse," who would afterwards be called Zizine, the feminine form of his name. There is the 1854 marriage certificate of Jérôme Zizine and his wife Elisabeth Elisa Escrabe, "âgée de 35 ans, majeure, née en Afrique de parents inconnus," explains the writer, herself an unknown distant relative, of the article I depend on for so much: "Elle a dî naître vers 1820, à une époque où la traite était déjà interdite: son introduction aux îles s'est donc faite clandestinement par un de ces navires négriers qui n' hésitait pas à jeter sa cargaison de chair humaine à l'eau en cas de difficulté."1 I am intrigued by this ancestress, Elisabeth Elisa Escrabe, who was captured and pillaged "illegally" after the official end of the French slave trade. How many like her were on those belated slave ships? Like the others in the Zizine line, the line she married into, her original nation and tribe of origin is a mystery: "In some desolate sense it was the creation place of Blacks in the New World Diaspora at the same time that it signified the end of traceable beginnings" (Map 5). Brand elaborates that "to live in the Black Diaspora is I think to live as a fiction-- a creation of empires, and also self-creation. It is to be a being living inside and outside of herself' (18).

One of the new creations was miscegenation, métissage, and what would lead to the categorization of people in the French Antilles according to pigmentation and type of 
features on a spectrum ranging between European and African: négresse, mulâtresse, câpresse, chabine, quadroon, octoroon. More complex than the infamous American "One Drop Rule" but just as omnipresent and ominous. Some people don't want to be divided up and counted like a dog, but I do. I want to count, to belong to something, even if the percentage in me of belonging is now so slim, so diluted. At a supermarket in Fort-deFrance, the capital of Martinique, I watch the evening shoppers, mostly parents shepherding their children who are just out of school and anxious for a snack. I am perversely interested in whether the children look like their parents and grandparents. How many are of mixed race? Are any also visibly Indian, Chinese, Lebanese, Syrian, Jewish? I compare hues and hair. I wonder, with shock, if this is what slave traders encouraged in potential buyers, this kind of ogling. But I am not looking to purchase someone's servitude. I am looking to find myself in the shoppers; I am looking for someone who looks like me. Recognition. I am looking for other mixed-race diasporic subjects. In Canada, we diasporans all look a bit lost, removed from our origins by at least one more degree than those who are in the Caribbean. In this shopping centre, everyone acts like they belong. They live here in this New World island-country; they are from here at least. As I watch the shoppers, I stand immobile because of the stinging sunburn I got accidentally that afternoon. Accidentally? Or was I trying to tan myself into belonging?

\section{Notes}

${ }^{1}$ Monique Palcy: "She was likely born around 1820, when the slave trade had already been abolished; her introduction to the islands was thus undertaken clandestinely by one of those slave ships that did not hesitate to throw its human cargo overboard in case of any difficulty while at sea." My translation. 


\section{Bibliography}

Agnant, Marie-Célie. Le livre d'Emma: roman. Montreal: Éditions de remue-ménage, 2001. Print.

Allen, Jafari S. "Black / Queer / Diaspora at the Current Conjuncture." GLQ: A Journal of Lesbian and Gay Studies. 18. 2-3 (2012): 211-48. Web. 13 Feb. 2014.

Anker, Elizabeth. Fictions of Dignity: Embodying Human Rights in World Literature. Ithaca: Cornell UP, 2012. Print.

Anzaldúa, Gloria. “To(o) queer the writer: loca, escrita y chicana." InVersions: Writing by Dykes, Queers, and Lesbians. Ed. Betsy Warland. Vancouver: Press Gang, 1991. 249-63. Print.

Arendt, Hannah. Eichmann in Jerusalem: A Report on the Banality of Evil. New York: Viking Press, 1964.

---. On Violence. New York: Brace, 1970.

---. The Origins of Totalitarianism. New York: Brace, 1966.

Asad, Talal. Formations of the Secular: Christianity, Islam, Modernity. Stanford: Stanford UP, 2003.

Austen, Jane. Emma. 1816. London: Bloomsbury, 1994. Print.

Balakian, Peter. Black Dog of Fate: A Memoir. New York: Basic Books, 1997. Print.

Baldick, Chris, ed. "Elegy." Oxford Dictionary of Literary Terms. 3rd ed. 2001. Print.

Balibar, Étienne. "Citizen Subject.” Eds. Eduardo Cadava, Peter Connor, and Jean-Luc Nancy. Who Comes After the Subject? New York: Routledge, 1991. 33-57. Print. 
Balutansky, Kathleen M. "Creating Her Own Image: Female Genesis in Mémoire d'une amnésique and Moi, Tituba sorcière ..." L'Héritage de Caliban. Ed. Maryse Condé. Pointe-à-Pitre, Guadeloupe: Jasor, 1992. 29-47.

Bakhtin, M. M. Rabelais and His World. Cambridge, MA: MIT Press, 1968. Print. Baucom, Ian. Specters of the Atlantic: Finance Capital, Slavery, and the Philosophy of History. Durham: Duke UP, 2005. Print.

Bellande-Robertson, Florence. “A Reading of the Marasa Concept in Lila Desquiron's Les Chemins de Loco-Miroir." Haitían Vodou: Spirit, Myth, and Reality. Eds. Patrick Bellegarde-Smith and Claudine Michel. Bloomington IN: Indiana UP, 2006. 103-111.

Bellegarde-Smith, Patrick. "Broken Mirrors: Mythos, Memories, and National History." Haitían Vodou: Spirit, Myth, and Reality. Eds. Patrick Bellegarde-Smith and Claudine Michel. Bloomington IN: Indiana UP, 2006.19-31.

Benítez Rojo, Antonio. The Repeating Island: The Caribbean and the Postmodern Perspective. Durham: Duke UP, 1992. Print.

Benjamin, Walter. "Theses on the Philosophy of History." Illuminations. 1st ed. New York: Harcourt, Brace \& World, 1968. Print.

Bennet, Jill. Empathic Vision: Affect, Trauma, and Contemporary Art. Stanford: Stanford UP, 2005. Print.

Bennett, Jill, and Rosanne Kennedy. World Memory: Personal Trajectories in Global Time. Houndsmills, UK: Palgrave Macmillan, 2003. Print.

Bhabha, Homi K. The Location of Culture. London: Routledge, 1994. Print. 
Blanco, Maria del Pilar and Esther Peeren, eds. The Spectralities Reader: Ghosts and Haunting in Contemporary Cultural Theory. London: Bloomsbury, 2013.

Bok, Francis, and Edward Tivnan. Escape From Slavery: The True Story of My Ten Years in Captivity--and My Journey to Freedom in America. New York: St. Martin's Press, 2003. Print.

Boggs, Nicholas. "Queer Black Studies: An Annotated Bibliography, 1994-1999.” Callaloo. Spec. Issue. "Plum Nelly: New Essays in Black Queer Studies.” 23.1 (2000). Web. 13 Feb. 2014.

Bongie, Chris. Islands and Exiles: The Creole Identities of Post/Colonial Literature. Stanford: Stanford UP, 1998. Print.

Bouris, Erica. Complex Political Victims. Bloomfield, CT: Kumarian Press, 2007. Print. Boyarin, Daniel, and Jonathan Boyarin. "Diaspora: Generation and the Ground of Jewish Identity." Critical Inquiry 19.4 (1993): 693-725. Print.

Braidotti, Rosi. Nomadic Subjects: Embodiment and Sexual Difference in Contemporary Feminist Theory. New York: Columbia UP, 1994. Print.

Brand, Dionne. A Map to the Door of No Return: Notes to Belonging. Toronto: Random House, 2001. Print.

---. At the Full and Change of the Moon: A Novel. Toronto: Random House, 1999. Print.

---. Bread Out of Stone: Recollections on Sex, Recognitions, Race, Dreaming and Politics. Toronto: Random House, 1994. Print.

---. In Another Place, Not Here. Toronto: Random House, 1997. Print.

---. Inventory. Toronto: McClelland \& Stewart, 2006. Print.

---. Land to Light On. Toronto: McClelland \& Stewart, 1997. Print. 
---. No Language is Neutral. Toronto: Coach House Press, 1990. Print.

---. Ossuaries. Toronto: McClelland \& Stewart, 2010. Print.

---. "She's a wanderer." Interview by Suzanne Methot. Quill \& Quire, April 1999. Web. 7 Jun. 2012.

---. Thirsty. Toronto: McClelland \& Stewart, 2002. Print.

---. What We All Long For. Toronto: Random House, 2008. Print.

Brathwaite, Edward Kamau. "The African Presence in Caribbean Literature." Daedalus 103.2 (Spring 1974). 73-109. Web. 20 Nov. 2012.

---. The Arrivants: A New World Trilogy. London: Oxford UP, 1973. Print.

Braziel, Jana Evans, and Anita Mannur. "Nation, Migration, Globalization: Points of Contention in Diaspora Studies.” Theorizing Diaspora: A Reader. Malden, MA: Blackwell, 2003. Print.

Britton, Celia M. "Globalization and Political Action in the Work of Édouard Glissant." Small Axe 13.330 (2009): 1-11. Web. 21. Dec. 2011.

Brubaker, Rogers. “The 'Diaspora' Diaspora.” Ethnic and Racial Studies 28.1 (January 2005):1-19. Web. 30 Sep. 2013.

Brydon, Diana. "Dionne Brand's Global Intimacies: Practicing Affective Citizenship. “ University of Toronto Quarterly: A Canadian Journal of the Humanities 76.3 (Summer 2007): 990-1006. Web. 19 Dec. 2011.

Burns, Lorna. "Becoming-Postcolonial, Becoming-Caribbean: Édouard Glissant and the Poetics of Creolization.” Textual Practice 23.1 (2009): 99-117. Web. 5 Feb. 2014. Butler, Judith. "Violence, Mourning, Politics." Precarious Life: The Powers of Mourning and Violence. New York: Verso, 2004. 19-50. Print. 
Butler, Kim. “Defining Diaspora, Refining a Discourse.” Diaspora 10.2 (2001): 189-219. Web. 30 Sep. 2013.

Butler, Octavia. Kindred. 1979. Boston: Beacon Press, 2003. Print.

Cadet, Jean. Restavec: From Haitian Slave Child to Middle-Class American. Austin: U of Texas P, 1998. Print.

Carpentier, Alejo. The Kingdom of this World. 1904. Trans. Harriet de Onis. London: Gollancz, 1967. Print.

Caruth, Cathy. Trauma: Explorations in Memory. Baltimore: Johns Hopkins UP, 1995. Print.

Casteel, Sarah Phillips. Calypso Jews: Jewishness in the Caribbean Literary Imagination. N.d. Unpublished book MS.

---. "Experiences of Arrival: Jewishness and Caribbean-Canadian Identity in Austin Clarke's The Meeting Point." Journal of West Indian Literature 14.1-2 (Nov.2005): 113-140. Web. 30 Sep. 2013.

---. Second Arrivals: Landscape and Belonging in Contemporary Writing of the Americas. Charlottesville: U of Virginia P, 2007. Print.

Castle, Gregory. Reading the Modernist Bildungsroman. Gainseville: Florida UP, 2006. Print.

Celan, Paul. "Speech at Bremen.” Selected Poems and Prose of Paul Celan. Ed. John Felstiner. New York: Norton, 2001. Print. 112.

Césaire, Aimé. Cahier d'un retour au pays natal. Paris: Présence africaine, 1971. Print. Césaire, Aimé, Léopold Senghor, Léon Damas. L'étudiant noir: journal de l'Association des étudiants martiniquais en France. Paris: Sauphanor, 1935. Print. 
Chamoiseau, Patrick. Écrire en pays dominé. Paris: Gallimard, 1997. Print.

Chancy, Myriam J. A. Searching for Safe Spaces: Afro-Caribbean Women Writers in Exile. Philadelphia: Temple UP, 1997. Print.

---. Prologue: "Natif-Natal." Searching for Safe Spaces: Afro-Caribbean Women Writers in Exile. Chancy xi-xxv. Print.

---. "Productive Contradictions: Afro-Caribbean Diasporic Feminism and the Question of Exile." Searching for Safe Spaces: Afro-Caribbean Women Writers in Exile. Chancy 1-30. Print.

---. The Loneliness of Angels. Leeds: Peepal Tree, 2010. Print.

Chariandy, David John. Soucouyant. Vancouver: Arsenal Pulp Press, 2007. Print.

Cheah, Pheng. Inhuman Conditions: On Cosmopolitanism and Human Rights. Cambridge, MA: Harvard UP, 2006. Print.

---. Spectral Nationality: Passages of Freedom from Kant to Postcolonial Literatures of Liberation. New York: Columbia UP, 2003. Print.

Child, Peter, and Roger Fowler, eds. "Elegy.” The Routledge Dictionary of Literary Terms. 2006. Print.

Christophe, Marc A. "Rainbow Over Water." Haitian Vodou: Spirit, Myth, and Reality. Eds. Patrick Bellegarde-Smith and Claudine Michel. Bloomington IN: Indiana UP, 2006. 84-102.

Cliff, Michelle. Abeng: A Novel. Trumansburg, NY: Crossing Press, 1984. Print.

---. Free Enterprise: A Novel of Mary Ellen Pleasant. San Francisco: City Lights, 2004. Print. 
---. "Preface: Journey Into Speech.” If I Could Write This Fire. Minneapolis, MN: U of Minnesota P, 2008. vii-xi.

Clifford, James. "Diasporas.” Cultural Anthropology 9.3 (1994): 302-338. Web. 13 Aug. 2013.

Collins, Jo. "Between Worlds: Imagining Dyaspora in Danticat's The Dew Breaker and Chancy's The Spirit of Haiti." ARIEL 42.3-4 (2011): 121-141. Web. 24 Nov. 2013.

Condé, Maryse. I, Tituba, Black Witch of Salem. Charlottesville, VA: UP of Virginia, 1992. Print.

---. Moi, Tituba Sorcière ... Noire de Salem. Paris: Gallimard, 1988. Print.

Craps, Stef. Postcolonial Witnessing: Trauma Out of Bounds. New York: Palgrave Macmillan, 2013. Print.

Craps, Stef, and Gert Buelens. Introduction. "Postcolonial Trauma Novels." Studies in the Novel 40.1-2 (2008): 1-13. Web. 21 Dec. 2011.

Crichlow, Wesley E. A. Buller Men and Batty Bwoys: Hidden Men in Toronto and Halifax Black Communities. Toronto: U of Toronto P, 2004. Print.

Crosta, Suzanne. "Breaking the Silence: Cultural Identities and Narrative Configurations in the French Caribbean Novel." Haigh 159-176. Print.

Cuddon, J. A. "Bildungsroman." The Penguin Dictionary of Literary Terms and Literary Theory. 4th ed. 1999. Print.

---. "Künstelrroman." The Penguin Dictionary of Literary Terms and Literary Theory. 4th ed. 1999. Print.

Dabydeen, David. The Intended. London: Secker \& Warburg, 1991. Print. 
---. Turner: New and Selected Poems. London: Cape Poetry, 1994. Print.

Danticat, Edwidge. "Bonjour Jean.” The Nation. 19 Feb. 2001: 20-22. Web.

---. Breath Eyes Memory. New York: Soho, 1994. Print.

---. Brother, I'm Dying. New York: Knopf, 2007. Print.

---. "Children of the Sea." Krik? Krak! New York: Soho, 2004. Print. 1-29.

---. Create Dangerously: The Immigrant Artist at Work. Princeton: Princeton UP, 2010. Print.

---. "Create Dangerously: The Immigrant Artist at Work." Create Dangerously. 1-21. Print.

---. “Our Guernica." Create Dangerously. 153-175. Print.

---, ed. The Butterfly's Way: Voices from the Haitian Dyaspora in the United States. New York: Soho Press, 2011. Print.

---. The Dew Breaker. New York: Knopf, 2004. Print.

Dash, J. Michael. "Fictions of Displacement: Locating Modern Haitian Narratives." Small Axe 27.27 (Oct. 2008): 32-41. Web.

---. The Other America: Caribbean Literature in a New World Context. Charlottesville, VA: U of Virginia P, 1998. Print.

Dash, J. Michael, Dany Laferrière, Louis-Phillippe Dalembert, Edwidge Danticat, Evelyne Trouillot. "Roundtable: Writing, History, and Revolution." Small Axe 18.18 (Sept. 2005): 189-199. Web. 21 Dec. 2011.

Davies, Carole Boyce. Black Women, Writing, and Identity: Migrations of the Subject. London: Routledge, 1994. Print.

Dawes, James. Evil Men. Cambridge, MA: Harvard UP, 2013. Print. 
---. "Human Rights in Literary Study.” Human Rights Quarterly 31.2 (May 2009): 394409. Web.

---. That The World May Know: Bearing Witness to Atrocity. Cambridge, MA: Harvard UP, 2007. Print.

Dayan, Joan. "Vodou, or the Voice of the Gods." Fernández Olmos and ParavasiniGebert 13-36. Print.

Debien, Gabriel. "Marronage in the French Caribbean." Rebel Slave Communities in the Americas. Ed. Richard Price. Baltimore: Johns Hopkins UP, 1979. Print. 107-135.

Defoe, Daniel. Moll Flanders. 1722. New York: Knopf, 1991. Print.

Deleuze, Gilles. "Nomad Thought.” 1973. The New Nietzsche. Ed. David B. Allison. Cambridge, Mass: MIT Press, 1990. 142-49. Print.

Deleuze, Gilles, and Félix Guattari. A Thousand Plateaus: Capitalism and Schizophrenia. Minneapolis: University of Minnesota Press, 1987. Print.

De Sousa, Pascale. "Folie de l'écriture, écriture de la folie dans la littérature féminine des Antilles françaises." Presence Francophone 63 (2004): 130-144. Web. 5 Feb. 2013.

DeVere Brody, Jennifer, and Dwight McBride, eds. Callaloo. Spec. Issue. "Plum Nelly: New Essays in Black Queer Studies.” 23.1 (2000). Web. 13 Feb. 2014.

Dickens, Charles. The Personal History of David Copperfield. 1850. London: Oxford UP, 1948. Print.

Dominique, Jan J. Mémoire d'une amnésique: récit. Port-au-Prince, Haiti: Deschamps, 1984. Print. 
---. Memoir of an Amnesiac. Trans. Irline François. Coconut Creek, FL: Caribbean Studies Press, 2008. Print.

Donnell, Alison. Twentieth-Century Caribbean Literature: Critical Moments in Anglophone Literary History. London: Routledge, 2006. Print.

Dorfman, Ariel. "Vocabulary." Trans. Ariel Dorfman and Edith Grossman. Against Forgetting: twentieth-century poetry of witness. Ed. Carolyn Forché. New York: Norton, 1993. 614-617. Print.

Douglas, Rachel. "Haitian Revolutions in Literature: The Case of Linguistic and Visual Inventiveness in Frankétienne. “ Small Axe 27.27 (Oct. 2008): 58-70. Web. 1 Dec. 2013.

Duff, Christine. Univers intimes: Pour une poétique de l'intériorité au féminin dans la littérature caribéene. Caribbean Studies Vol. 17. New York: Peter Lang, 2008. Print.

Dunnage, Jonathan. "Perpetrator Memory and Memories About Perpetrators." Memory Studies 3.2 (April 2010): 91-94. Web. 19 June 2013.

Equiano, Olaudah, and Shelly Eversley. The Interesting Narrative of the Life of Olaudah Equiano, or, Gustavus Vassa, the African. New York: Modern Library, 2004. Print.

Espinet, Ramabai. The Swinging Bridge. Toronto: Harper, 2007. Print.

Fanon, Frantz. Black Skin, White Masks. 1967. Trans. Charles Lam Markmann. London: Pluto Press, 2008. Print.

Felman, Shoshana, and Dori Laub. Testimony: Crises of Witnessing in Literature, Psychoanalysis, and History. New York: Routledge, 1991. Print. 
Ferguson, Roderick. Aberrations in Black: Toward a Queer of Color Critique. London, MN: U of Minnesota P, 2004.

Fernández Olmos, Margarite and Lizabeth Paravasini-Gebert, eds. Sacred Possessions: Vodou, Santeria, Obeah and the Caribbean. New Brunswick, NJ: Rutgers UP, 1997. Print.

---. Introduction. Sacred Possessions: Vodou, Santeria, Obeah and the Caribbean. Fernández Olmos and Paravasini-Gebert 1-12. Print.

Flaubert, Gustave. L'Éducation sentimentale: histoire d'un jeune homme. (1869). Paris: Garnier,1936. Print.

Fleurant, Gerdès. "Vodun, Music, and Society in Haiti." Haitían Vodou: Spirit, Myth, and Reality. Eds. Patrick Bellegarde-Smith and Claudine Michel. Bloomington IN: Indiana UP, 2006. 46-57.

Foer, Jonathan Saffran. Everything is Illuminated: A Novel. Boston: Houghton Mifflin, 2002. Print.

Forché, Carolyn, ed. Introduction. Against Forgetting: Twentieth-Century Poetry of Witness. By Carolyn Forché. New York: Norton, 1993. 29-48. Print.

---. "Reading the Living Archives: The Witness of Literary Art." Goldberg and Moore 135-148. Print.

---. The Angel of History. New York: Harper Collins, 1994. Print.

François, Irline. "From Confinement to Freedom: Jan J. [Gigi] Dominique's Mémoire d'une amnésique." Écrire en pays assiégé / Writing Under Siege. Eds. MarieAgnes Sourieau and Kathleen M. Balutansky. Amsterdam: Rodopi, 2004. 285302. Print. 
García, Cristina. Dreaming in Cuban. New York: Knopf, 1992. Print.

Garvey, Johanna X. K. "Spaces of Violence, Desire, and Queer (Un)belonging: Dionne Brand's Urban Diasporas.” Textual Practice 25.4 (Aug. 2011): 757-777. Web. 20 Nov. 2013.

Gilbert, Bart. Postcolonial Life-Writing: Culture, Politics, and Self-Representation. London: Routledge, 2009. Print.

Gilroy, Paul. The Black Atlantic: Modernity and Double Consciousness. Cambridge, MA: Harvard UP, 1993. Print.

Githire, Njeri. "Horizon Adrift: Women in Exile, at Home, and Abroad in Gisèle Pineau's Works.” Research in African Literatures 36.1 (Spring 2005): 74-90. Web. 4 Feb. 2013.

Glave, Thomas. Our Caribbean: Gay and Lesbian Writing from the Antilles. Durham, NC: Duke UP, 2008.

Glissant, Édouard. Caribbean Discourse: Selected Essays. Trans. J. Michael Dash. Charlottesville, VA: UP of Virginia, 1989. Print.

---. Le Discours antillais. Paris: Editions du Seuil, 1981. Print.

---. La Lézarde. Paris: Gallimard, 1958. Print.

---. Poetics of Relation. Trans. Betsy Wing. Ann Arbor: U of Michigan P, 1997. Print.

---. Traité du tout-monde. 1997. Paris: Gallimard, 1997. Print.

Goethe. Wilhelm Meister's Apprenticeship: A Novel. London: G. \& W.B. Whittaker, 1824. Print.

Goldberg, Elizabeth Swanson. Beyond Terror: Gender, Narrative, Human Rights. New Brunswick, NJ: Rutgers UP, 2007. Print. 
Goldberg, Elizabeth Swanson, and Alexandra Schultheis Moore, eds. Theoretical Perspectives on Human Rights and Literature. New York: Routledge, 2012. Print.

---. Introduction. "Human Rights and Literature: The Development of an Interdiscipline." Goldberg and Moore 3-19. Print.

Gopinath, Gayatri. Impossible Desires: Queer Diasporas and South Asian Public Cultures. Durham: Duke UP, 2005. Print.

---. "Nostalgia, desire, diaspora: South Asian Sexualities in Motion.” Positions: East Asia Cultures Critique 5.2 (Sept. 1997): 467-89. Web. 20 Nov. 2013.

Goya, Chantal and Jean-Jacques Debout. “Adieu les jolis foulards.”. RCA Victor, 1975.

Green, Mary Jean, Karen Gould, Micheline Rice-Maximin, Keith L. Walker, Jack A. Yeager, eds. Postcolonial Subjects: Francophone Women Writers. Minneapolis: U of Minnesota P, 1996. Print.

---. Introduction: “Women Writing Beyond the Hexagon.” Postcolonial Subjects: Francophone Women Writers. Green, Mary Jean et al. ix-3. Print.

Haigh, Sam, ed. An Introduction to Caribbean Francophone Writing: Guadeloupe and Martinique. New York: Berg, 1999. Print.

Haley, Alex. Roots. Garden City, NY: Doubleday, 1976. Print.

Hall, Stuart. "Cultural Identity and Diaspora." Identity and Difference. Ed. Kathryn Woodward. London: Sage, 1997. 51-59. Print.

Hartman, Saidiya V. Lose Your Mother: A Journey Along the Atlantic Slave Route. New York: Farrar, Straus and Giroux, 2007. Print.

Hesford, Wendy. Spectacular Rhetorics: Human Rights, Visions, Recognitions, Feminism. Durham, NC: Duke UP, 2011. Print. 
Hirsch, Marianne. “The Generation of Postmemory.” Poetics Today 29.1 (2008): 103128. Web. 1 Dec. 2013.

---. The Generation of Postmemory: Writing and Visual Culture After the Holocaust. New York: Columbia UP, 2012. Print.

Hirsch, Marianne, and Nancy K. Miller, eds. Rites of Return: Diaspora Poetics and the Politics of Memory. New York: Columbia UP, 2011. Print.

---. Introduction. Rites of Return: Diaspora Poetics and the Politics of Memory. Hirsch and Miller 1-20. Print.

Hoffman, Eva. Lost in Translation: A Life in a New Language. New York: E. P. Dutton, 1989. Print.

Hunt, Lynn. Inventing Human Rights: A History. New York: Norton, 2007. Print.

Huston, Nancy. Fault Lines. London: Atlantic, 2008. Print.

Huyssen, Andreas. "Monument and Memory in a Postmodern Age." The Yale Journal of Criticism 6.2 (1993): 249-262. Web. 1 Dec. 2013.

James, Cynthia. The Maroon Narrative: Caribbean Literature in English Across Boundaries, Ethnicities, and Centuries. Portsmouth, NH: Heinemann, 2002. Print.

Johnson, E. Patrick, and Mae Henderson. Black Queer Studies: A Critical Anthology. Durham, NC: Duke UP, 2005.

Johnson, Erica L. Caribbean Ghostwriting. Madison, NJ: Fairleigh Dickinson UP, 2009. Print.

Joyce, James. A Portrait of the Artist as a Young Man. 1916. New York: Viking, 1964. Print. 
Kamboureli, Smaro. On the Edge of Genre: The Contemporary Canadian Long Poem. Toronto: U of T Press, 1991. Print.

Kincaid, Jamaica. Annie John. New York: Farrar, Straus and Giroux, 1985. Print.

---. A Small Place. New York: Farrar, Straus and Giroux, 1988. Print.

---. Lucy. New York: Farrar, Straus and Giroux, 1990. Print.

Krog, Antjie. Country of My Skull: Guilt, Sorrow, and the Limits of Forgiveness in the New South Africa. New York: Random House, 1998. Print.

LaBine, Joseph. Blog. “Review of an October Performance of M. NourbeSe Philip's 'Zong!'” Flat Singles Press. 8 Apr. 2014. Blog. Web. 8 May 2014.

LaCapra, Dominick. Writing History, Writing Trauma. Baltimore: Johns Hopkins UP, 2001. Print.

Lacrosil, Michèle. Sapotille et le serin d'argile. Paris: Gallimard, 1960. Print.

Laferrière, Dany. “Afterword.” Trans. Martin Munro. Small Axe 9.2 (Sept. 2005): 202204. Web. 24 Aug. 2011.

---. Tout bouge autour de moi. Paris: Grasset, 2011. Print.

Laroche, Maximilien. "Mythe africain et mythe antillais: le personnage du zombi." Revue canadienne des etudes africaines 9.3 (1975): 479-491. Web. 25 Aug. 2011.

Laub, Dori. "Truth and Testimony: The Process and the Struggle." Caruth 61-75. Print. Lee, Rachel. "Notes from the (Non) Field: Teaching and Theorizing Women of Colour. " Women's Studies on Its Own: A Next Wave Reader in Institutional Change. Ed. Robyn Wiegman. Durham, NC: Duke UP, 2002. 82-105. Print.

Lessing, Doris. Children of Violence. New York: Simon \& Schuster, 1964. Print. 
Levinas, Emmanuel. Otherwise Than Being or Beyond Essence. Trans. Alphonso Lingis. Boston: Kluwer, 1981. Print.

Lhérisson, Justin. Zoune chez sa ninnaine. Port-au-Prince, Haiti: Presse nationale d'Haït, 1906. Print.

Lionnet, Françoise. Autobiographical Voices: Race, Gender, and Self-Portraiture. New York: Cornell UP, 1989. Print.

Loomba, Ania. Colonialism/Postcolonialism. New York: Routledge, 1998. Print.

Lousley, Cheryl. "Witness to the Body Count: Planetary Ethics in Dionne Brand's Inventory." Canadian Poetry: Studies, Documents, Reviews 63 (Fall-Winter 2008): 37-58. Web. 19 Dec. 2011.

Mahmood, Saba. The Politics of Piety: The Islamic Revival and the Feminist Subject. Princeton, NJ: Princeton UP, 2005.

Mann, Thomas. Doktor Faustus. 1947. London: Random House, 1966. Print. Márquez, Gabriel Garcia. One Hundred Years of Solitude. 1st Ed. New York: Harper \& Row, 1970. Print.

McLennan, Sophia and Joseph Slaughter. "Introducing Human Rights and Literary Forms; or, The Vehicles and Vocabularies of Human Rights." Human Rights and Literary Forms. Spec. Issue of Comparative Literature Studies 46.1 (2009): 1-19. Web. 3 Oct. 2010.

McLeod, Corinna. “Constructing a Nation: Jamaica Kincaid's A Small Place.” Small Axe 25.25 (Feb. 2008): 77-92. Web. 24 Sept. 2013.

McWatt, Tessa. Out of My Skin. Toronto: Riverbank, 1998. Print. 
Mehta, Brinda J. Notions of Identity, Diaspora, and Gender in Caribbean Women's Writing. New York: Palgrave Macmillan, 2009. Print.

---. "Dyasporic Trauma, Memory, and Migration in Edwidge Danticat's The Dew Breaker." Mehta 63-88. Print.

Menchú, Rigoberta and Elisabeth Debray. I, Rigoberta Menchú: An Indian Woman in Guatemala. London: Verso, 1984. Print.

Metraux, Alfred. Le Vaudou Haïtien. Gallimard: Paris, 1958.

Minow, Martha. Between Vengeance and Forgiveness: Facing History After Genocide and Mass Violence. Boston: Beacon Press, 1998. Print.

"Monitoring the Trial of Emmanuel Toto Constant." Center for Constitutional Rights. Web. 6 Oct. 2011. https://ccrjustice.org/monitoring-trial-emmanuel-toto-constant Mootoo, Shani. Cereus Blooms at Night. Vancouver: Press Gang, 1996. Print.

Moretti, Franco. The Way of the World: The Bildungsroman in European Culture. London: Verso, 1987. Print.

Morrison, Toni. Beloved: A Novel. New York: Knopf, 1987. Print.

Moscovitch, Hannah. East of Berlin. Toronto: Playwrights Canada Press, 2009. Print. Muñoz, José Esteban. Cruising Utopia: The Then and There of Queer Futurity. New York: New York UP, 2009.

Munro, Martin, and Elizabeth Walcott-Hackshaw, eds. Reinterpreting the Haitian Revolution and Its Cultural Aftershocks. St. Augustine: University of the West Indies, 2006. Print.

---. "Lahen's Revolution, or the Words Within." Munro and Walcott-Hackshaw 38-55. 
Murphy, Joseph M. Working the Spirit: Ceremonies of the African Diaspora. Boston: Beacon Press, 1994.

Naudillon, Françoise. "Le continent noire des corps: representation du corps féminin chez Marie-Célie Agnant et Gisèle Pineau.”Études françaises 41.2 (2005): 73-85. Web. 4 Feb. 2013.

Oliver, Kelly. Witnessing: Beyond Recognition. Minneapolis: U of Minnesota P, 2001. Print.

Ormerod, Beverley. "The Representation of Women in French Caribbean Fiction.” An Introduction to Caribbean Francophone Writing: Guadeloupe and Martinique. New York: Berg, 1999. 101-119. Print.

Page, Kezia Ann. Transnational Negotiations in Caribbean Diasporic Literature: Remitting the Text. New York: Routledge, 2011. Print.

Palcy, Monique. "Charles et Pierre Zizine." Notre bulletin. Association Martiniquaise de Recherche sur l'Histoire des Familles. 13 (Sept. 2006): 3-10. Web. 12 May 2011. Paravasani-Gebert, Lizbeth. "Colonial and Postcolonial Gothic: The Caribbean." The Cambridge Companion to Gothic Fiction. Ed. Jerrold E. Hogle. Cambridge, UK: Cambridge UP, 2002. 229-257. Print.

---. Women Possessed: Eroticism and Exoticism in the Representation of Woman as Zombie.” Fernández Olmos and Paravasini-Gebert 37-58. Print.

Patton, Paul. Deleuze and the Political. New York: Routledge, 2000. Print. Philip, Marlene NourbeSe. "Defending the Dead, Confronting the Archive: A Conversation with M. NourbeSe Philip.” Interview by Patricia Saunders. Small Axe 26 12.2 (June 2008): 63-79. Web. 22 Nov. 2013. 
---. She Tries Her Tongue, Her Silence Softly Breaks. Charlottetown, PEI: Ragweed, 1989. Print.

---. "Discourse on the Logic of Language." She Tries Her Tongue. 55-60. Print.

---. "The Absence of Writing or How I Almost Became a Spy.” She Tries Her Tongue. 10-26. Print.

Philip, M. NourbeSe, and Setaey Adamu Boateng. ZONG! Middletown, CT: Wesleyan UP, 2008. Print.

---. "Notanda." ZONG! 187-209. Print.

---. “Gregson v. Gilbert.” ZONG! 210-211. Print.

Pineau, Gisèle. Chair piment: roman. Paris: Mercure de France, 2002. Print.

---. “ 'Devoured by Writing': An Interview with Gisèle Pineau.” Interview by Valérie Loichot. Callaloo: A Journal of African Diaspora Arts and Letters 30.1 (Winter 2007): 328-37. Web. 22 Nov. 2013.

---. L'espérance macadam. Paris: Stock, 1995. Print.

---. L'exil selon Julia. Paris: Stock, 2006. Print.

---. Morne Câpresse. Paris: Mercure de France, 2008. Print.

---. Un papillon dans la cité. Paris: Sepia, 2009. Print.

Pinto, Samantha. Difficult Diasporas: The Transnational Feminist Aesthetic of the Black Atlantic. New York: New York UP, 2013. Print.

Price, Richard, ed. Rebel Slave Communities in the Americas. Baltimore: Johns Hopkins UP, 1979. Print

Prosser, Jay. "Singing with the Taxi Driver: From Bollywood to Babylon." Hirsch and Miller 137-151. Print. 
Quinn, Joanna R. "Haiti's Failed Truth Commission: Lessons in Transitional Justice.” Journal of Human Rights 8.3 (2009): 265-281. Web. 19 Jun. 2013.

Ratcliffe, Krista. Rhetorical Listening: Identification, Gender, Whiteness. Carbondale, IL: Southern Illinois UP, 2005. Print.

Rhys, Jean. Wide Sargasso Sea. London: Norton, 1982. Print.

Rich, Adrienne. An Atlas of the Difficult World: Poems, 1988-1991. New York: Norton, 1991. Print.

Rohrleitner, Marion Christina. “ 'Breaking the Silence': Testimonio, Revisionary Historiography, and Survivor's Guilt in Edwidge Danticat's The Farming of Bones and The Dew Breaker.” Interdisciplinary Humanities 28.1 (Spring 2011): 73-85. Web. 24 Nov. 2013.

Rothberg, Michael. Multidirectional Memory: Remembering the Holocaust in the Age of Decolonization. Stanford: Stanford UP, 2009. Print.

Roumain, Jacques. Masters of the Dew. 1947. London: Heinemann, 1978. Print.

Rudd, Alison. Postcolonial Gothic Fictions from the Caribbean, Canada, Australia and New Zealand. Cardiff: U of Wales P, 2010. Print.

Rushdie, Salman. Imaginary Homelands: Essays and Criticism, 1981-1991. London: Granta Books, 1991. Print.

Said, Edward. Culture and Imperialism. New York: Knopf, 1993. Print.

---. Orientalism. New York: Vintage, 1979. Print.

---. Reflections on Exile and Other Essays. Cambridge, MA: Harvard UP, 2000. Print. 
Savory, Elaine. "Ex/Isle: Separation, Memory and Desire in Caribbean Women's Writing." MaComère: Journal of the Association of Caribbean Women Writers and Scholars 1 (1998): 170-78. Web. 3 July 2012.

Schaffer, Kay, and Sidonie Smith. Human Rights and Narrated Lives: The Ethics of Recognition. New York: Palgrave Macmillan, 2004. Print.

Schwartz-Bart, Simone. Pluie et vent sur Télumée Miracle: roman. Paris: Éditions du Seuil, 1972. Print.

Scott, David. Foreword. Small Axe 18 9. 2 (Sept. 200): v-vi. Web. 24 Aug. 2011.

---. Omens of Adversity: Tragedy, Time, Memory, Justice. Durham, NC: Duke UP, 2014.

---. Preface. "Paths Are Made By Walking." Small Axe 2712.3 (Oct. 2008): v-viii. Web. 24 Aug. 2011.

Sharpe, Jenny. Ghosts of Slavery: A Literary Archeology of Black Women's Lives. Minneapolis, MN: U of Minnesota P, 2003. Print.

Simon, Roger. The Touch of the Past: Remembrance, Learning, and Ethics. New York: Palgrave Macmillan, 2005. Print.

---. "The Touch of the Past: The Pedagogical Significance of a Transactional Sphere of Public Memory." Simon 87-103. Print.

Simon, Roger, and Claudia Eppert. "Remembering Obligation: Witnessing Testimonies of Historical Trauma." Simon 50-65. Print.

Slaughter, Joseph. Human Rights Inc.: The World Novel, Narrative Form, and International Law. New York: Fordham UP, 2007. Print.

---. Foreward. Theoretical Perspectives on Human Rights and Literature. Goldberg and Moore xv-xv. Print. 
Smith, Sidonie. A Poetics of Women's Autobiography: Marginality and the Fictions of Self-Representation. Bloomington: Indiana UP, 1987. Print.

Smith, Sidonie, and Julia Watson. Women, Autobiography, Theory: A Reader. Madison: U of Madison P, 1998. Print.

Smyth, Heather. “' 'She Had Made a Beginning Too': Beka Lamb and the Caribbean Feminist Bildungsroman.” Genre 44.2 (Summer 2011): 181-204. Web. 24 Nov. 2013.

Sourieau, Marie-Agnès. “Tactiques narratives dans Mémoire d'une amnésique de J.J. Dominique." The French Review 68.4 (March 1995): 694-70. Web. 18 Dec. 2012. Spearey, Susan. "Displacement, Dispossession, and Conciliation: The Politics and Poetics of Homecoming in Antje Krog's Country of My Skull." Scrutiny 2: Issues in English Studies in Southern Africa 5.1 (2000): 64-77. Web. 17 Nov. 2010.

Spiegelman, Art. Maus: A Survivor's Tale. New York: Pantheon, 1986. Print.

Spivak, Gayatri. "Can the Subaltern Speak?" Marxism and the Interpretation of Culture. Basingstock, UK: Macmillan, 1988. 271-313. Print.

Stanley, Liz. The Auto/biographical I: The Theory and Practice of Feminist Auto/Biography. Manchester: Manchester UP, 1992. Print.

Stowe, Harriet Beecher, Henry Louis Gates and Hollis Robbins. The Annotated Uncle Tom's Cabin. New York: Norton, 2007. Print.

Sugars, Cynthia, and Gerry Turcotte. Unsettled Remains: Canadian Literature and the Postcolonial Gothic. Waterloo, ON: Wilfred Laurier UP, 2009. Print.

Sullivan, Nikki. “Queer Race.” A Critical Introduction to Queer Theory. New York: New York UP, 2003. 57-80. Print. 
Tabti, Bouba Mohammedi. “Des 'Gouverneurs' aux 'Briseurs' de rosée: Le Briseur de rosée d'Edwidge Danticat." Présences haïtiennes. Eds. Sylvie Bouffartigue, Christiane Chaulet Achour, Dominique Fattier, et Françoise Moulin Civil. CRTF et CiCC: Université de Cergy-Pontoise, 2006. 341-356. Print.

Taylor, Diana. The Archive and the Repertoire: Performing Cultural Memory in the Americas. Durham: Duke UP, 2003. Print.

Teitel, Darrah. Corpus. Canadian Theatre Review 153 (Winter 2013): 58-93. Print. The Holy Bible. The Papal Edition. Ed. John P. O'Connell. Chicago: The Catholic Press, 1966. Print.

Tinsley, Omise'eke Natasha. "Black Atlantic/Queer Atlantic.” GLQ: A Journal of Lesbian and Gay Studies. 14.2 (2008): 191-215. Web. 13 Feb. 2014.

---. Thiefin' Sugar: Eroticism Between Women in Caribbean Literature. Durham, NC: Duke UP, 2010.

Torres, Lourdes. "The Construction of the Self in U.S. Latina Autobiographies." Third World Women and the Politics of Feminism. Eds. Chandra Talpade Mohanty, Ann Russo, and Lourdes Torres. Bloomington: Indiana UP, 1991. 271-87. Print.

Twain, Mark, and Emory Elliott. The Adventures of Huckleberry Finn. Oxford: Oxford UP, 1999. Print.

UN Department of Public Information. Universal Declaration of Human Rights 60th Anniversary Spec. Edition, 1948-2008. UN: 2007. Web. 21 Dec. 2011.

Vellino, Brenda Carr. “ 'History's Pulse Measured With Another Hand': Precarity Archives and Translocal Witness in Dionne Brand's Inventory." University of 
Toronto Quarterly: A Canadian Journal of the Humanities 82.2 (Spring 2013): 242-260. Web. 22 Nov. 2013.

Vermeulen, Pieter. "Dispersal and redemption: the future dynamics of memory studiesa roundtable." Memory Studies 5.2 (Apr. 2012): 223-239. Web. 19 June 2013.

Visser, Irene. "Trauma Theory and Postcolonial Literary Studies. ” Journal of Postcolonial Writing 47.3 (Aug. 2011): 270-282. Web. 21 Dec. 2011.

Waisvisz, Sarah. "Fugitive Rhythms: Re Imagining Diasporic Caribbean-Canadian Communities in Dionne Brand's What We All Long For." The Caribbean Woman Writer as Scholar: Creating, Imagining, Theorizing. Ed. Keshia N. Abraham. Coconut Creek FL: Caribbean Studies Press, 2009. 395-411. Print.

Walcott, Derek. The Antilles: Fragments of Epic Memory. The Nobel Lecture. New York: Farrar, Straus, and Giroux, 1993. Print.

---. Omeros. 3rd Edition. New York: Farrar, Straus, Giroux, 1991. Print.

---. "The Schooner Flight." Collected Poems 1948-1984. New York: Farrar, Straus and Giroux, 1986. Print.

Walcott, Rinaldo. "Outside in Black Studies: Reading from a Queer Place in the Diaspora." Black Queer Studies: A Critical Anthology. Eds. E. Patrick Johnson and Mae G. Henderson. Durham: Duke UP, 2005. 90-105. Web. 20 Nov. 2013.

---. "Somewhere Out There: The New Black Queer Theory." Blackness and Sexualities. Eds. Michelle M. Wright and Antje Schuhmann. Munster: LIT Verlag, 2007. 2940. Print.

Walcott-Hackshaw, Elizabeth. "Home is Where the Heart Is: Danticat's Landscapes of Return.” Small Axe 27.27 (October 2008): 71-82. Web. 24 Aug. 2011. 
Walker, Alice. The Colour Purple. 1982. New York: Harcourt, 1992. Print.

Walker, Rebecca. Black, White, and Jewish: Autobiography of a Shifting Self. New York: Riverhead Books, 2001. Print.

Warnes, Christopher. Magical Realism and the Postcolonial Novel: Between Faith and Irreverence. Houndmills, UK: Palgrave Macmillan, 2009. Print.

Weinstock, Jeffrey Andrew, ed. Spectral America: Phantoms and the National Imagination. Madison, WI: U of Wisconsin Press, 2004.

Wieland, Cristoph Martin. Agathon. Leipzig: Weidman and Reich, 1773. Print.

Wright, Michelle, and Antje Schuhmann. Blackness and Sexualities. Münster: LIT Verlag, 2007.

Wuthnow, Julie. "Deleuze in the postcolonial: On Nomads and Indigenous Politics." Feminist Theory 3.2 (Aug. 2002): 183-200. Web. 28 Sept. 2013.

Young, James E. At Memory's Edge: After Images of the Holocaust in Contemporary Art and Architecture. New Haven: Yale UP, 2000. Print.

Zobel, Joseph. La rue Cases-Nègres. Paris: Présence africaine, 1950. Print.

Zimra, Clarisse. "Negritude in the Feminine Mode: The Case of Martinique and Guadeloupe.” Journal of Ethnic Studies 12.1 (Spring 1984): 53-77. Web. 26 Sep. 2011. 